University of Louisville

ThinkIR: The University of Louisville's Institutional Repository

Electronic Theses and Dissertations

$5-2005$

\title{
Characterization of microbial communities in karstic sediments : a study of cave bacteria in central Kentucky.
}

Justine Kay Roback 1964-

University of Louisville

Follow this and additional works at: https://ir.library.louisville.edu/etd

Part of the Biology Commons

\section{Recommended Citation}

Roback, Justine Kay 1964-, "Characterization of microbial communities in karstic sediments : a study of cave bacteria in central Kentucky." (2005). Electronic Theses and Dissertations. Paper 1213.

https://doi.org/10.18297/etd/1213

This Doctoral Dissertation is brought to you for free and open access by ThinkIR: The University of Louisville's Institutional Repository. It has been accepted for inclusion in Electronic Theses and Dissertations by an authorized administrator of ThinkIR: The University of Louisville's Institutional Repository. This title appears here courtesy of the author, who has retained all other copyrights. For more information, please contact thinkir@louisville.edu. 
CHARACTERIZATION OF MICROBIAL COMMUNITIES

IN KARSTIC SEDIMENTS: A STUDY OF CAVE BACTERIA IN CENTRAL KENTUCKY

\author{
By \\ Justine Kay Roback \\ B.S., University of Kentucky, 1987 \\ M.S., University of Louisville, 2002

\begin{abstract}
A Dissertation
Submitted to the Faculty of the Graduate School of the University of Louisville in Partial Fulfillment of the Requirements for the Degree of
\end{abstract}

Doctor of Philosophy

Department of Biology

University of Louisville

Louisville, Kentucky

May 2005 

Copyright 2005 by Justine K. Roback

All rights reserved 


\title{
CHARACTERIZATION OF MICROBIAL COMMUNITIES
} IN KARSTIC SEDIMENTS

\author{
by \\ Justine Kay Roback \\ B.S., University of Kentucky, 1987 \\ M.S., University of Louisville, 2002 \\ A Dissertation Approved on
}

April 25, 2005

by the following Dissertation Committee:

Dissertation Director - Ronald M. Atlas, $\mathrm{PhD}$

Clara A. Leuthart, PhD

William D. Pearson, PhD

Michael H. Perlin, PhD

R. Jan Stevenson, PhD 


\section{DEDICATION}

This dissertation is dedicated to "The Village People"

I think you know who you are and I hope you know how much I appreciate your support. This degree would not be possible without you. 


\section{ACKNOWLEDGEMENTS}

This presented work would not be possible without the help of a number of people. Elizabeth Bowman at Applied Biosystems supplied the rTth polymerase for evaluation. John Mang and Sam Sarma at Whip-Mix Corp. performed the particle size analysis and provided insight regarding interpretation of the results. The calcium analyses were performed by Rich Schultz who was in no way responsible for my taking so long to finish.

Thank you to Dr. William Pearson who introduced me to the cave ecosystem and was an ever-present guide both in and out of the dark underground. I would be remiss in not thanking Dan and Grace Cash and Mr. Jack Mays for their hospitality in allowing me access to their property and for the information they provided in personal communication regarding their caves.

I am indebted to the Biology office staff: Kathy, Lisa, and Nancy who allowed me to make their office mine, and went above and beyond the call of their duty to make things as easy as they could for me. They never failed to produce the appropriate documents and supplies to get things done. Dr. Fell was very patient in the presence of a family camped out in the department.

Many thanks to all my labmates for sharing ideas, food, and friendship around the table in the depths of the basement. Our discussions were a major part of my graduate education. And to all of those who entertained, listened, encouraged, cajoled, and taught me, Zeke, and Kezi. 
On a more personal note, I want to thank my family for all of their interest in my finishing, especially when things got stressful in the end. Thank you can never express the appreciation for Kevin, my husband and best friend, who never let me give up the notion that this could be done and my two beautiful F1 who lived a large part of their first years in the biology department.

I owe eternal gratitude to Mindy, my "housemate" and friend for life who helped maintain my sanity and positive attitude and made living away from home not only possible, but bearable. Thanks for being there and helping to keep the perspective on what $\mathrm{PhD}$ really stands for!

Lastly, but not the least important, I want to thank my committee, especially my advisor, Dr. Atlas, for the continued interest in my project and success. It has been a long road and your support is greatly appreciated. 


\section{ABSTRACT \\ CHARACTERIZATION OF MICROBIAL COMMUNITIES IN KARSTIC SEDIMENTS \\ Justine Kay Roback}

April 25, 2005

Few previous studies have compared microbial communities in subterranean and surface environments. Chemical analyses used to characterize the surface and cave microbial environments indicated limited exchange between surface and subsurface waters. Here, bacterial communities from four distinct cave sediments collected in central Kentucky and adjacent surface streams were compared using a combination of culture and molecular methods. Predictions were that: 1) Cave communities will have unique community structures when compared to those of nearby surface sediments, and 2) Genetic diversity of bacterial communities in cave sediments will be higher than those in nearby surface sediments. Since diversity and community structure influence the ability of biological communities to respond to environmental disturbance, it is important to understand the ecological role of bacterial communities in cave sediments.

A combination of plate counts and direct counts by epifluorescent staining were used to enumerate bacteria. When cell numbers were compared to sediments, average particle size was positively correlated with plate counts but had a higher indirect relationship to direct cell counts using DAPI stain and epifluorescent microscopy. Cell counts varied between sites. Visual characterization of the cultured bacteria revealed observed higher proportions of pigmented bacteria in surface sediments. This is likely light influenced as 
cave sediment bacteria were mostly colorless. Levels of the pigments chlorophyll $a$ and pheophytin were also negligible in the cave waters sampled.

Amplified ribosomal DNA restriction analysis (ARDRA) and reassociation kinetics were used for molecular analyses of DNA extracted from the surface and cave communities. High calcium concentrations in the karstic sediments sampled made the molecular analyses by these methods complicated. It is likely that calcium and other compounds interfered with sphectrophotometric methods as well. In addition to purification to reduce calcium and other inhibitors, dilution of extracts to $1 / 100$ or $1 / 1000$ was necessary for amplification of in-situ extracted DNA. However, DNA extracted from cultured communities was easily amplifiable.

Conclusions from the community structure analyses are that the cave microbial communities sampled contained different members than the adjacent surface sediments as detected by digestion of $16 \mathrm{~S}$ rDNA from the cultured and in-situ extracted bacterial communities. In addition, cave sites sampled had unique community structures when compared to each other. Cultured community signatures were less complex when compared to the total community $16 \mathrm{~S}$ amplicons by ARDRA. This method is, and will continue to be, useful for comparing bacterial community structure in different habitats, over time, or in response to environmental changes.

Comparison of diversity by reassociation indicated that cave microbial communities contained similar genetic complexity as those in adjacent surface sediments. Rates of reassociation were different for $16 \mathrm{~S}$ amplicons from cultured and in-situ extracts. With careful selection of methods for extraction and purification, and proper interpretation of results for reassociation rates of $16 \mathrm{~S}$ rDNA amplicons, this method can provide useful genetic and taxonomic information about bacterial communities. 


\section{LIST OF FIGURES}

1. 1997 USDA Census of Agriculture Map of Kentucky indicating the number of acres in farmland.

2. Illustration of proximal elevations and distance between sampling sites in the Howe Valley Quadrangle

3. Illustration of proximal elevations and distance between sampling sites in the Garfield Quadrangle.

4. Sinking Creek Sampling Site in December 2000.................................................45

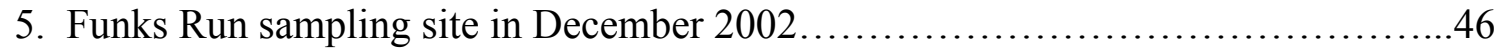

6. Topographical map indicating the GPS coordinates of sampling sites in Breckinridge County, Kentucky....

7. Topographical map indicating the GPS coordinates of sampling sites in Hardin County, Kentucky

8. Rimstone sampling site (Pen 2) in Penitentiary Cave, Breckinridge County, Kentucky

9. Sampling site (Belt 1) in Belt Cave, Hardin County, Kentucky.

10. Drip pool sampling site (Pen 1) in Penitentiary Cave, Breckinridge County, Kentucky.

11. Nomograph used for determination of percent saturation of dissolved oxygen in water column samples.

12. Photograph of filtration apparatus for direct cell counts using epiflourescent microscopy.

13. Chlorophyll $a$ and Phaeophyton in cave and surface waters of Breckinridge and Hardin counties, Kentucky.... 
14. Temperature fluctuation in cave and surface waters of Breckinridge and Hardin Counties, Kentucky 1998-2002.

15. Conductivity of Cave and Surface Waters in Breckinridge and Hardin Counties, Kentucky 1998-2002.

16. $\mathrm{pH}$ Measurements of cave and surface waters in Breckinridge and Hardin Counties, Kentucky 1998-2002.

17. Chloride concentrations in cave and surface waters of Breckinridge and Hardin Counties, Kentucky 1998-2002.

18. Silica concentrations in cave and surface waters of Breckinridge and Hardin Counties, Kentucky 1998-2002.

19. Dissolved organic carbon levels in surface and cave waters 82

20. Nitrogen levels in cave and surface waters of Breckinridge and Hardin Counties, Kentucky 1998-2002.

21. Soluble Reactive Phosphorus (SRP) in cave and surface waters of Breckinridge and Hardin Counties, Kentucky 1998-2002.

22. Graph of calcium levels in surface and cave water column samples.

23. Photo of sediment samples from Sinking Creek, Funks Run, and Belt 2 used for analysis .88

24. Photo of sediment samples from Belt 1, Pen 2, and Pen 1 used for analysis

25. Mean particle size of cave and surface sediments. .90

26. Particle size scan of surface and cave sediments from 2,000 to $0.04 \mu \mathrm{m}$....................91

27. Photograph of cultured community extracts on $1 \%$ agarose gel.....................93

28. Photo of agarose gel containing DNA extracts from 10 grams of surface and cave sediments.

29. Comparison of PCR product from cultured bacteria extracts or from in-situ extracted sediments.

30. Photo of extracts from a co-extraction of $E$. coli and cave sediment compared to a mixture of E. coli and cave sediment extracts after extraction and the effects on successful PCR amplification. 
31. Amplification of 16S rDNA from E. coli when spiked with cave sediment extracts

32. Comparison of calcium levels in sediments and extracts from same sediments.

33. Inhibition of PCR amplification from $E$. coli DNA by the addition of increasing concentrations of calcium chloride.

34. Inhibition of PCR amplification from a cave sediment extract by the addition of increasing concentrations of calcium chloride.

35. Effect of increasing concentrations of calcium carbonate on the successful amplification of $16 \mathrm{srDNA}$ from E. coli template.

36. Effect of increasing concentrations of calcium carbonate on the successful amplification of $16 \mathrm{srDNA}$ from extracts of cave microbes cultured in the cave environment

37. Effect of the addition of PVPP during extraction on the successful amplification of $16 \mathrm{~S}$ rDNA from cave sediments

38. Effect of 5.5M GTC rinse on amplification of DNA from cave sediments.

39. PCR amplification products from extracts produced with and without additional GTC rinse

40. Effect of 10mM EGTA on successful amplication of $16 \mathrm{~S}$ rDNA from cave sediments.

41. Effect of template dilution on successful PCR amplification of $16 \mathrm{~S}$ rDNA from cave sediment extracts.

42. Gel electrophoresis of unpurified and purified 16S amplicons

43. Graph of colony forming units on R2A plates.

44. Photo of colonies from surface sediment on R2A.................................................124

45. Photo of colonies from cave sediments on R2A .125

46. ARDRA signatures of cultured community DNA from cave and surface samples

47. Photograph of total community $16 \mathrm{~S}$ amplicons on $1 \%$ agarose gel 130 
48. Photograph of total community ARDRA signatures for cave and surface samples on $4 \%$ agarose gel......................................................................132

49. Photograph of total community ARDRA signatures using concentrated PCR product.........................................................................133

50. Nucleic Acid Concentration and Reassociation rates..............................................136

51. Reassociation of total DNA from Belt Cave compared to E. coli.............................139

52. Reassociation of total extracted DNA from cave and surface sediments ................140

53. Reassociation of total community $16 \mathrm{~S}$ amplicons from cave sediments...................143

54. Reassociation of cultured community $16 \mathrm{~S}$ amplicons.............................................145 


\section{LIST OF TABLES}

1. Primer sequences of primer pairs used for PCR amplification...................................64

2. Ranking of study sites for selected physical and chemical properties......................78

3. Physical and chemical properties of surface and cave waters in Breckinridge and Hardin Counties, Kentucky in January, 2000................................79

4. Calcium concentrations in cave and surface waters from Breckinridge

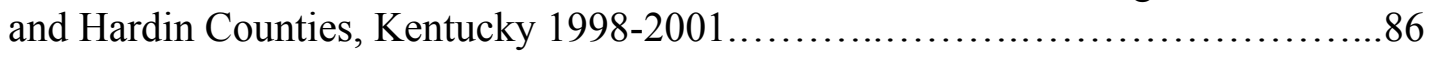

5. Yield and purity of plate cultured community extracts by absorbance spectrophotometry...

6. Yield and purity of DNA extracts from sediment samples........................96

7. Actual and theoretical yields of DNA from collected sediment samples............98

8. Calcium levels in digested sediments and DNA extracts.........................103

9. Absorbance value ratios with and without the addition of PVPP in the extraction procedure

10. Absorbance values for $16 \mathrm{~S}$ rDNA from E. coli before and after purification.

11. Comparison of direct cell counts and plate counts on R2A

12. Calculated correlation of similarity (Cs) values for ARDRA signatures of cultured community DNA of cave and surface samples.

13. Absorbance readings of pooled, cleaned, and concentrated total community amplicons diluted $1 / 300$ in 1 XTNE.

14. Calculated correlation of similarity (Cs) values for total community ARDRA signatures

15. Minimal detection of nucleic acids by spectrophotometry. .136 
16. Absorbance values for cave and surface sediment total community

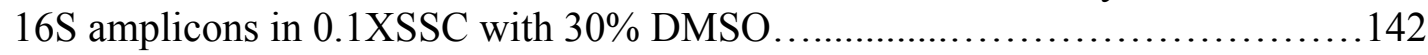

17. Absorbance readings of concentrated, cultured $16 \mathrm{~S}$ amplicons

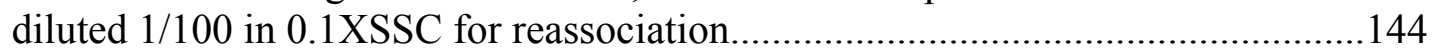


TABLE OF CONTENTS

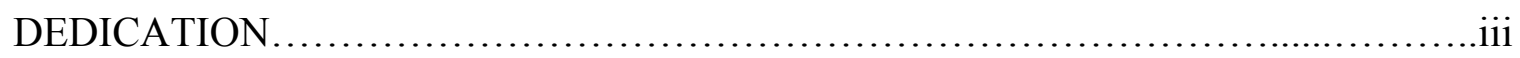

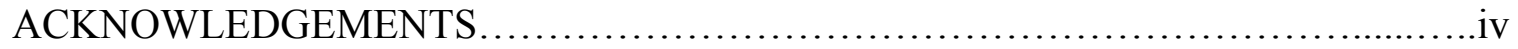

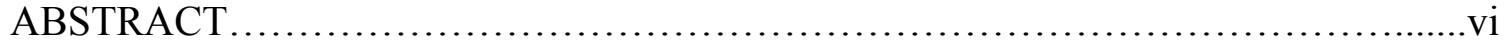

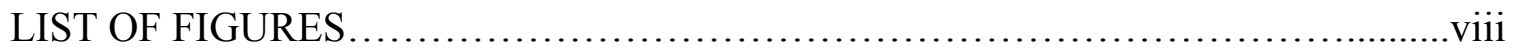

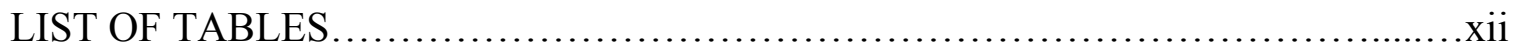

I. INTRODUCTION

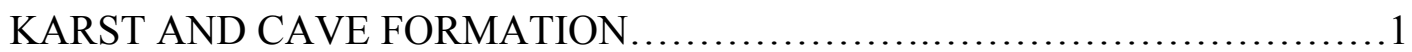

THE LINK BETWEEN SURFACE AND SUBTERRANEAN $. . . \ldots \ldots \ldots \ldots \ldots \ldots . . . . . . . . .3$

THE CAVE ENVIRONMENT AND ADAPTATION $\ldots \ldots \ldots \ldots \ldots \ldots \ldots \ldots \ldots \ldots . \ldots$

MICROORGANISMS IN CAVE ENVIRONMENTS ......................... 10

DIVERSITY AND REGULATING FACTORS.......................... . 17

MEASURING MICROBIAL DIVERSITY ..................................24

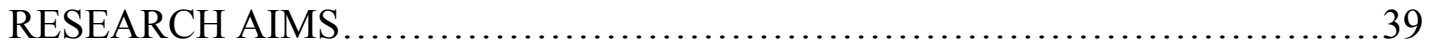

II. METHODS

A. CHARACTERIZATION OF CAVES

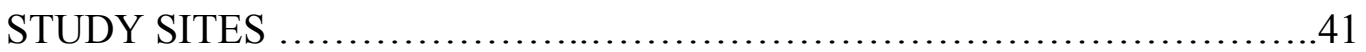

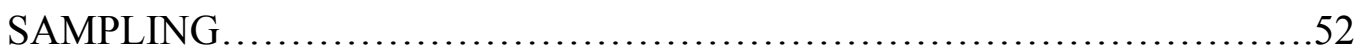

PHYSICAL AND CHEMICAL MEASUREMENTS .........................52

B. CHARACTERIZATION OF MICROORGANISMS

PLATE COUNTS ..................................................56

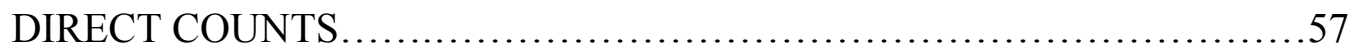

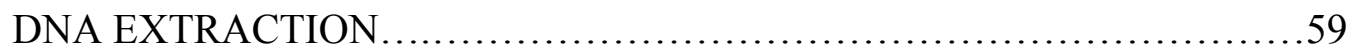


POLYMERASE CHAIN REACTION ...................................62

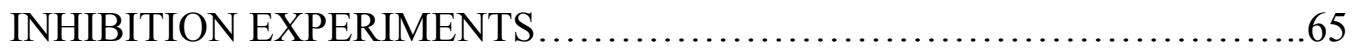

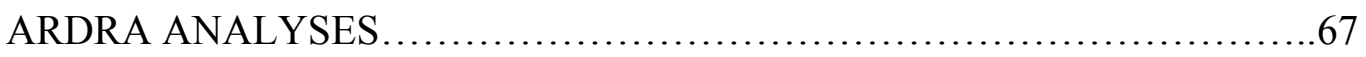

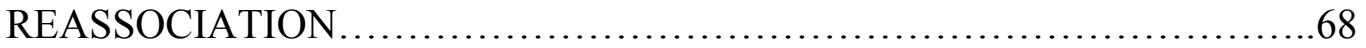

III. RESULTS

A. PHYSICAL AND CHEMICAL PROPERTIES.................................................

B. NUCLEIC ACIDS: EXTRACTION AND AMPLIFICATION............................92

C. DIVERSITY AND COMMUNITY STRUCTURE............................................121

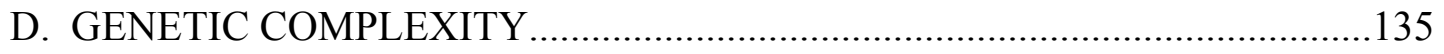

IV. DISCUSSION

A. PHYSICAL AND CHEMICAL CHARACTERIZATIONS................................146

B. DNA EXTRACTION AND AMPLIFICATION.............................................151

C. MICROBIAL COMMUNITES.................................................................158

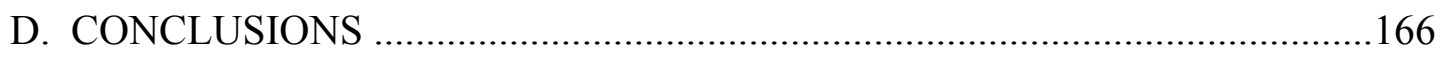

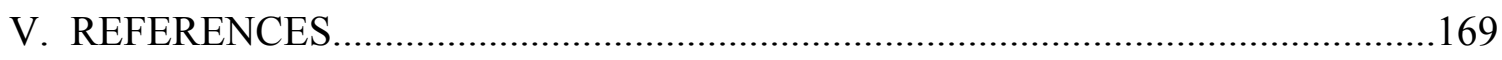

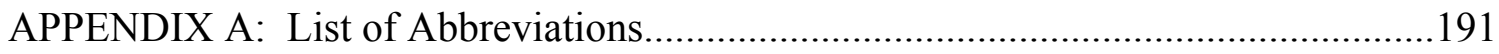

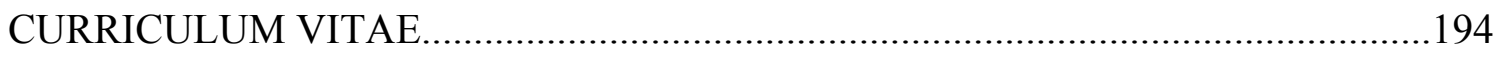

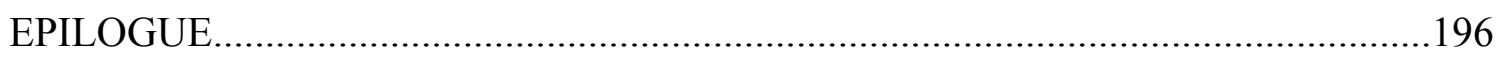




\section{INTRODUCTION}

\section{KARST AND CAVE FORMATION}

Karst refers to a topography characterized by distinctive features such as sinkholes, vertical shafts, caverns, underground streams, and springs (Rusterholz and Mallory, 1994). In the central part of the commonwealth, most development occurs in the Girkin, Ste. Genevieve, and St. Louis limestone layers (Gillieson 1996). The main constituent of limestone is calcite, the commonest of the calcium carbonate $\left(\mathrm{CaCO}_{3}\right)$ minerals. These rock formations originated as sedimentary deposits on the shallow ocean floor covering the southern portion of North America approximately 300 million years ago (Rusterholz and Mallory 1994). In places, this limestone is overlain by insoluble sandstones and shales. These insoluble layers form the ridges of the Chester Upland which determine drainage patterns in the Kentucky karst system. It is estimated that $55 \%$ of Kentucky is karst terrain (Currens 2002), making the formation of caves very likely. Caves formed by means other than dissolution such as wind caves, mines, or lava tubes are termed pseudokarst, and thus excluded from this discussion.

Karst topography encourages the formation of underground passages comprised of a network of channels, which transport water, solutes, and sediments from one input (streamsink) or a multitude of inputs to lower surface connections called springs. Results of dye tracing indicate many springs and/or streamsinks in the central Kentucky region 
are interconnected (Gillieson 1996). These waters may enter the subterranean system through cracks and fissures (Howarth 1983). Water entering the system of subterranean passages may originate from surface streams (a streamsink) or percolate through overlying soil. Caves in the Kentucky karst area are formed when waters infiltrate the soil matrix and are acidified by carbon dioxide within the soil to form carbonic acid. Cave passages are formed by the process of subsurface rock dissolution when infiltrating waters bind dissolved $\mathrm{CO} 2$ forming a weak carbonic acid. Limestone is soluble in the carbonic acid under normal temperature and pressure so ions dissociate and are carried by gravity along with fine sediment and dissolved organic acids from vegetation through these cracks and plane surfaces. As the path for infiltration is established, passages enlarge over time, sometimes forming underground caves or caverns. The resulting underground passages are referred to as caves when there is access from the surface or ocean, and they are large enough for a human to enter. There are 722 caves documented in Breckinridge ( $\mathrm{n}=425)$ and Hardin ( $\mathrm{n}=297)$ counties, Kentucky (George 1985) and over 3,700 in the entire commonwealth.

Caves in this region are formed in limestone rock composed of carbonates such as calcite $(\mathrm{CaCO} 3)$ and its close relatives aragonite $\left(\right.$ also $\left.\mathrm{CaCO}_{3}\right)$ and dolomite $\left(\mathrm{CaMg}\left(\mathrm{CO}_{3}\right)_{2}\right)$. These type of caves are often referred to as "common caves" (Ford and Williams 1989). In this type of cave formation, surface vegetation can affect development of the karst system by the biogenic production of carbon dioxide in the root zone and by compounds produced by the particular surface vegetation which may be leached from the soils into the subsurface environment. Vegetation also acts to intercept waters and solutes by leaf litter and tree roots. $\mathrm{As}^{\mathrm{CO}} \mathrm{O}_{2}$ saturated waters enter cave passages and are exposed to the cave atmosphere, these waters equilibrate with their 
surroundings. This causes the precipitation of calcite or other minerals in solution along with the release of $\mathrm{CO}_{2}$. Together, calcite and aragonite make up 95\% of all cave minerals (Gillieson 1996). These precipitates create a variety of cave formations, called speleothems, inside the cave passages.

While the majority of caves are formed by carbonic acid, some are formed by a process termed sulfuric acid speleogenesis. Caves like Carlsbad Caverns, Lechugilla Cave, and others in the Guadalupe mountains of southeastern New Mexico and west Texas, are among just $10 \%$ in the United States formed primarily by sulfuric acid reactions (Palmer 1991). Microorganisms associated with natural gas and petroleum deposits may reduce sulfate $\left(\mathrm{SO}_{4}\right)$ or sulfate compounds such as gypsum anhydrite $\left(\mathrm{CaSO}_{4}\right)$ to hydrogen sulfide under anaerobic conditions (Orr 1977). Caves are formed

when microorganisms degrading petroleum compounds produce hydrogen sulfide which reacts with water and oxygen to form sulfuric acid. This acid bubbles up from below dissolving the limestone and forming the cave passages. Sulfuric acid speleogenesis theories were first proposed in the 1970s and are now widely accepted as the primary mechanism for formation of caves in that area (Jagnow et al. 2000). The geology and speleogenesis of these caves has been described at length by Jagnow et al. (1977) and Hill $(1987,2000)$.

\section{THE LINK BETWEEN SURFACE AND SUBTERRANEAN}

Karst aquifers typically possess several chemically distinct recharge sources: internal runoff, diffuse infiltration, and sinking streams (Drake and Harmon 1973). Water properties of drip pools are different from those waters entering a cave directly from surface streams. Land use influence may be more evident in surface waters than in 
groundwater which has had a longer resident time in interstitial soil spaces. The temperature of subterranean streams is also influenced by waterflow from the surface. The temperature in caves is tied closely to the local average surface air temperature. As an example, the average surface air temperature in Breckinridge County, Kentucky $12.2^{\circ} \mathrm{C}$ (reported as $54^{\circ} \mathrm{F}$ at www.caves.org). So, while surface air temperatures vary annually, the temperature of cave waters in this area is always near $13^{\circ} \mathrm{C}$. In contrast, the average cave pool temperature in caves of the Guadalupe Mountains of New Mexico is $18.5^{\circ} \mathrm{C}$ (Turin and Plummer 2000).

Land use combined with drainage patterns determine the potential for soil components such as silt, nutrients, and organics carried by surface streams to impact subterranean water. When pollutants enter the karst system, the extensive network of passages allow dispersal of these pollutants over a wide area (Gillieson 1996). Agriculture, silviculture, industry, mining, and tourism have all been demonstrated to have an impact on subterranean stream chemistries and cave communities. Today, cave communities are even being threatened by the invasion of millipedes, sowbugs, ants, and cockroaches into cave systems (Elliott 1992, 1992b). Illegal dumping of refuse, inadequate sewage treatment or improper sewage disposal, closure of cave entrances or sinkholes by trash or siltation, pesticides, herbicides, animal waste, mining or quarrying activities, and human visitors to caves are examples of how human activities influence waterflow and water chemistries in subsurface streams (Northup et al. 2000). In the area near Breckinridge County, Kentucky there may be increased siltation due to U.S. Army exercises at Ft. Knox, Kentucky (Pearson 2000). Oil wells in this area also may affect the quality of underground waters. However, much of the surrounding land is used for agriculture or silviculture. 
A number of hydrology and dye tracing studies performed in this area indicate hydrological communication between drainage basins either by continuous seepage or as overflow during high stage flow conditions (Quinlan and Ray 1989; White and White 1989; Quinlan et al. 1983; Meiman and Ryan 1993; Meiman et al. 2001). Studies have been performed in this area to investigate water flow through the karst system and the effects on cave communities (Currens 2001). Hidden River Cave in Kentucky has been the site of study and exemplary restoration since being polluted by domestic sewage, creamery waste, and industrial waste between 1880 and 1970 (Lewis et al. 1983). Blind cave fish (Typhlichthys subterraneus) became locally extinct and the only surviving aquatic organisms detected in the oxygen depleted waters were bloodworms and sewage bacteria, including the filamentous, sheathed bacterium Sphaerotilus natans. Today, blind cave fish can again be found in the cave system (Lewis 2000) along with cave adapted crayfish, isopods, and amphipods. However, since microbes as part of the cave community are often not studied, little is known about the bacterial diversity (Gillieson 1996).

\section{THE CAVE ENVIRONMENT AND ADAPTATION}

Aside from the obvious lack of light, cave streams have quite different physical, chemical, and biological properties than those of adjacent surface streams. Perhaps the most important solutes in karst chemistry are carbon dioxide, dissolved organic acids, calcium, magnesium, bicarbonate ions, and some heavy metals. Naturally occurring iron or manganese is often oxidized and can be seen precipitated on cave stream sediments or on top of cave streams (White 1997). Other metals found in karst aquifers such as calcium and magnesium are derived from the carbonate rock. These metals can also 
adsorb onto clays and other particulates. In fact, the controlling factor of metal concentration and transport in karst appears to be adsorption to substrate and not equilibrium solubility (Vesper et al. 2001). Sodium, postassium, sulfates, and chloride are likely derived from atmospheric exchange or ion exchange in overlying soils and rock. The source of nitrates in the cave environment has been the subject of a number of studies. Nitrates have been attributed to human and animal wastes deposited in and above the cave (Mayer 1999). Turin and Plummer (2000) speculated that both atmospheric deposition and in-cave biological activity contribute to nitrate concentrations in cave pools.

In a study of Lechugilla Cave in New Mexico, the dominant ions found in cave pools were calcium, magnesium, carbonate, bicarbonate, and sulfate. Other ions present included silica, potassium, sodium, chloride, and nitrate (Turin and Plummer 2000). A study of Pettyjohns Cave within the Mississipian Bangor limestone in Northwest Georgia (Mayer 1999) compared surface and subsurface water chemistries from 1997 to 1999 and revealed total dissolved ion concentrations (TDI) 10-30 times higher from cave drip pools than adjacent surface waters. Cave waters collected from various sites within the cave were very similar in major ion chemistries. Surface waters were very undersaturated with respect to calcium, magnesium, and bicarbonate. Surface waters contained only $0.62-1.05 \mathrm{mg}$ calcium/L while those from cave sites ranged from 49.1 to $70.7 \mathrm{mg} / \mathrm{L}$. Concentrations of bicarbonate ions $\left(\mathrm{HCO}_{3}\right)$ were $204 \mathrm{mg} / \mathrm{L}$ compared to quantities of $<1 \mathrm{mg} / \mathrm{L}$ in surface water samples. Stevens and McKinley (1995) reported higher sulfur concentrations in deeper aquifer waters.

Cave waters and sediments may have different $\mathrm{pH}$ values than those of surface environments. Stevens and McKinley (1995) distinguished between shallow and deep 
aquifer water chemistries, and found that shallow ground waters in the Columbia River Basalt Group, Washington State had moderate $\mathrm{pH}$ values between 7.5 and 8.5 while those at greater depths varied from 8 to 10.5. Lechuguilla Cave waters studied by Turin and Plummer (2000) had reported $\mathrm{pH}$ levels between 8-8.5. Water samples from thirteen pools within Carlsbad Cavern, New Mexico, had a mean pH value of 8.5 (Forbes 2000). Studies of soils and surface sediments report $\mathrm{pH}$ values generally lower than neutral. Nusslein and Tiedje (1999) found forest soils to be $\mathrm{pH} 4.2$ compared to values of 5.2 in pature soils sampled. In a comparative study between soils in an agricultural region of New York, all soil samples investigated by Miller et al. (1999) had $\mathrm{pH}$ values between 5.7 and 6.5 .

Carbon dioxide levels in the cave atmosphere are generally high. In some areas of caves other gases such as radon, hydrogen sulfide, ammonia, or methane may also occur at elevated concentrations. While $\mathrm{CO}_{2}$ comprises only a small fraction of the surface atmosphere $(0.03 \%)$ some cave environments with foul air may contain as much as 25 $30 \%$, a level which is quickly lethal to humans (Smith 2003). Levels of $\mathrm{CO}_{2}$ in the atmosphere of Carlsbad Caverns were 5 times greater than surface atmospheric levels in some sampling locations (Forbes 2000).

In spite of its seeming hostility, The cave environment is in some ways very stable with little or no diurnal variation, stable temperature, and a relatively constant high humidity. The substrate is perpetually wet in many caves and the air is nearly saturated with water vapor (Gillieson 1996). Relative humidity (RH) measured at a cave location in Porto Badisco, Italy, showed that while RH on the surface fluctuated between $60-97 \%$, humidity inside the cave over a year of study remained consistently near 98\% (Laiz et al. 2000). 
Accompanied by some available energy, these attributes of cave environments are conducive to occupation by specialized invertebrates (Howarth 1983; Holsinger 1988; the karst environment provides habitat for a unique group of terrestrial and aquatic organisms including bats, fish, crayfish, freshwater shrimp, insects, and microorganisms. Elliott and Reddell 1989). However, despite the relative stability, cave environments are generally considered to be extreme environments because of their lack of light and low nutrients (Lavoie et al. 2000).

Subterranean ecosystems are unlike their surface counterparts for one overriding reason, a lack of light and thus photoautotrophic organisms. Nearly all biological communities are supported by photosynthesis (Sarbu et al. 1996). Barr (1968) determined nutrient availability to be a limiting factor in subterranean diversity. Although earlier statements that nearly all food energy in caves must be imported from the exterior (Holsinger 1988) have been disproven in some cases, many cave communities do rely on episodic transport of organic materials derived from photosynthetic activity in the surface environment (Stevens and McKinley 1995). Dissolved organic carbon (DOC) was determined to be seasonally dependent in Alta Mira Cave, Spain with levels ranging from $<5$ to $2200 \mathrm{mg} / \mathrm{L}$ (Groth and Saiz-Jimenez 1999). Water from two cave pools sampled within Mammoth Cave, Kentucky contained 37$41 \mu \mathrm{g} / \mathrm{L}$ of total organic carbon (TOC) (Rusterholz and Mallory 1994).

Until about 20 years ago, scientists speculated that cave dwelling organisms were refugees from climate and landscape changes in the surface environment (Holsinger 1974). Intermittant glaciers in the northern regions of the United States explained why troglodytes were most commonly found in the temperate regions and scarce or absent in the tropics (Culver and Sket 2000). However, obligate cave species have now been 
discovered in tropical cave environments with great diversity (DeHarveng 2002). Of course geological and geographical differences influence the physical, chemical, and biological components of the cave environment.

Because of the physical and chemical differences between the surface and subterranean environments, obligate cave dwelling organisms have some unique adaptations. High levels of carbon dioxide and low temperatures may lead to decreased metabolism (Poulson and White 1969). Many cave species have fat stores to deal with the intermittant food availability (Culver 1982). Cave dwellers may exhibit elongated appendages, enlarged antennae or bristles, and specialized organs for detecting vibration in addition to significant eye and pigment reduction, wing loss, and loss of water regulatory mechanisms (Peck 1976). Many cave dwellers are smaller in size and have different reproductive cycles than their surface counterparts (Poulson 1969). Subterranean organisms exhibit increased birth size and a longer developmental period along with a decreased number of eggs compared to similar organisms in surface environments (Culver 1982).

Slower rates of reproduction may lead to smaller population sizes in the cave ecosystem (Poulson 1969). In addition, communities of aquatic organisms may become isolated in pools as streambeds become lower due to continuing solution of the limestone, or during flood events as waters recede (Gillieson 1996). Small, isolated populations of some cave organisms have exhibited decreased genetic variation compared to their surface counterparts (Borowsky and Vidthayanon 2001). 


\section{MICROORGANISMS IN CAVE ENVIRONMENTS}

Kentucky contains a high diversity of cave fauna compared to much of the United States (Peck 1998). Culver and Sket (2000) state that $<1 \%$ of karst land area contains $>50 \%$ of aquatic subterranean species. However, many questions remain as to the diversity of microorganisms found in this environment, their mode of entry into the cave system, their rates of survival, and their role as primary producers and biochemical engineers.

The earliest group of bacteria studied, and still the most commonly studied bacteria in karst and groundwater are those defined as fecal coliforms or the fecal streptococci. The presence of coliforms and fecal streptococci is usually considered an indication of pollution from human or animal waste. The Clean Water Act (CWA) of 1977 mandates that each state establish, equip, and maintain a water quality surveillance system not only for surface waters but for ground waters as well (Pye and Patrick 1983). Coliform bacteria are used by many government and other agencies for monitoring pollution. In a study of the Butler Cave - Sinking Creek system in Virginia, Chess (1987) evaluated the populations of total and coliform bacteria. The same populations of organisms were found at the sinking surface streams, deep within the system, and at the discharging springs. Many studies have focused on introduction of foreign bacteria to the cave environment. Bacteria introduced to the cave environment can affect both the microbial cave community and the cave community as a whole, acting as might any other contaminant. Caldwell (1991) reported that organic debris deposited in particular cave pools by visitors in Carlsbad Cavern had created anoxic conditions that altered the natural microbiology of these pools. Although recently questioned (NSS Bulletin 2005), sampling in the Red Lake of Lechuguilla Cave, New Mexico (Northup et al. 2000) 
demonstrated the persistence of introduced fecal coliform bacteria after 14 months.

Bacteria may enter a cave in many ways. Gut endosymbionts or parasitic microbes may find their way into the cave through other cave dwelling organisms or from human excursions. Airborne surface microorganisms can be transported during inhalation phases of the cave (Cunningham et al. 1995). In addition, both aquatic and soil microbes may be introduced from streamsinks and seepages. Viruses, bacteria, and protozoa can easily be transported into the karst system during rain events (Vesper et al. 2001). These introduced microbes may or may not contribute to the microbial community structure in karstic sediments as data regarding die-off rates of surface organisms is sparse.

Investigations have revealed a rich diversity of organisms that thrive within karst systems (Cunningham et al. 1995). Bacteria in caves have been studied from the vadose (unsaturated subsurface), speleothems, still pools, cave sediments, and atmospheric cave samples. These studies of cave bacteria have investigated metabolism, taxonomy, phylogeny, and cell density (Sarbu et al. 1996; Engel et al. 2001; Jimenez 1990; Lewis et al. 1992; Taylor and Webb 2000; Rusterholz and Mallory 1994; Boston 1999, 2001; Stevens and McKinley 1995; Cunningham et al. 1995).

Mammoth Cave, Kentucky, was the site of a 1989 study to determine the density and diversity of microbial cells in the longest cave system in the world (Rusterholtz and Mallory 1994). Using both high and low-nutrient media researchers isolated bacterial colonies from two sites in Echo River, the lowest level in the cave. Colonies on solid media were typically small, circular, and white to off-white. Cells were generally nonmotile, short rods or coccobacilli. Gram staining revealed a majority of the isolates to be gram positive or gram variable. Comparison of direct cell counts and viable cell counts indicated that anywhere from $11-58 \%$ of the direct counts were represented depending 
upon the sampling location and media type used for culture. Isolates from both media ( $\mathrm{n}=237$ ) were examined for 117 morphological, biochemical, and physiological characteristics.

Ninety-two percent of the Mammoth Cave isolates grew at a $\mathrm{pH}$ of 9 and many were capable of growth at $\mathrm{NaCl}$ concentrations as high as $7.5 \%$. Bacterial strains isolated on the low nutrient media showed more carbon source flexibility when tested for sole carbon source utilization. Of all strains evaluated, $11 \%$ utilized cellulose as a sole carbon source and $62 \%$ were able to grow on cellobiose, a degradation product of cellulose. This could be a useful metabolism in an environment where organic carbon sources are limited and plant matter is often introduced during rain events. While the two sites differed only in the amount of water received from ground water percolation, bacterial populations varied between sites. Of the 200 clustered isolates, $26 \%$ were isolated exclusively from one site and $16.5 \%$ were isolated only from the second sampling location.

Cell densities also varied significantly. Total direct counts using acridine orange stain ranged from $3.9 \times 10^{6}$ to $1.4 \times 10^{7}$ cells/gram wet wt. of sediment. Greater water input was related to an eightfold increase in cell numbers found on high nutrient media, in spite of dissolved organic carbon being equal at the two sites. This difference in cell numbers was attributed to high nutrient adapted species entering the cave system with percolating water (Rusterholz and Mallory 1994). When plated on high nutrient media, bacterial species adapted to oligotrophic conditions may have been competitively excluded. Conclusions from the Mammoth Cave study (Rusterholz and Mallory 1994) were that bacterial communities in the karstic sediments exhibited a high degree of diversity with no dominant strain or strains. The high number of actively respiring bacteria observed indicated that these were likely adapted to the karstic environment. 
A study to determine the extent, type, and distribution of microbes in Lechugilla Cave, New Mexico was carried out by sampling pool waters, atmospheric condensate, and ceiling bound residues (Cunningham et al. 1995). Densities of nearly $5 \times 10^{5}$ cells/gm of sediment were estimated using standard nutrient agar streak plates. One previous aquifer study (Balkwill et al. 1989) reported bacterial counts on R2A agar of $3.8 \times 10^{6}$ cells $/ \mathrm{gm}$ in the surface soil, $1.4 \times 10^{4}$ cells/gm in the vadose soil, and $6.4 \times$ $10^{3}$ cells/gm in the saturated subsurface soil Direct bacterial cell count numbers in a limestone cave of Eastern Siberia ranged from $10^{3}$ to $10^{7}$ cells/gm (Khizhnyak et al. 2003). An aquifer region of South Carolina has been studied for years (Balkwill 1990) with numbers of bacteria ranging from $1 \times 10^{5}$ to $1 \times 10^{8}$ cells/gm. Aerobic or facultatively anaerobic chemoheterotrophs were the most predominant organisms in this system.

Based upon cell counts of bacteria in thermally altered, deep subsurface sediments (179 m) at Cerro Negro, New Mexico, Zlatkin et al. (1996) estimated only $0.1 \%$ of the bacterial population was culturable. A characterization of the culturable portion of those isolates revealed a majority $(67 \%)$ to be gram positive members of genera with high $\mathrm{G}+\mathrm{C}$ content DNA. Also, comparing three types of agar plates for culture, R2A agar allowed for recovery of a larger proportion of the microbial community from these sediments. Based on cellular fatty acid (FAME) profiles, which classified 92 isolates into 76 distinct species in 28 different genera, the conclusion was that the microbial community in those sediments studied was very diverse (Zlatkin et al.1996).

Microbes have been found in association with carbonate and silicate cave formations, sulfur compounds, iron, and manganese (Northup et al. 1997). Bacteria found in iron and manganese rich corrosion residues within Lechugilla Cave were found to be close 
relatives of bacteria known to utilize iron or manganese in an oxidation pathway (Cunningham et al. 1995). Groth et al. (1999) studied the effect of microbial communities on paleolithic paintings in caves of northern Spain. Previous studies have revealed a biodeteriorative role of actinomyces growing on rock paintings and murals (Laiz et al. 2000). Using morphological and chemotaxonomic methods, they found actinomycetes of the genus Streptomyces to be the most abundant bacteria cultivated on peptone agar from stalactites in Grotta dei Cervi, Italy (Laiz et al. 2000).

Traditional cultivation studies of soils have isolated bacterial species from the Clostridium, Bacillus, Arthrobacter, Brevibacterium, Corynebacterium, Micrococcus, and Pseudomonas genera. Other genera commonly found are Acinetobacter, Agrobacterium, Alcaligenes, Caulobacter, Flavobacterium, Hyphomicrobium, Metallogenium, Sarcina, Staphylococcus, Streptococcus, and Xanthomonas (Alexander 1977; Atlas and Bartha 1993; Tate 1995). Previous studies have shown many cave bacteria are also found in soils and surface sediments including actinomycetes, nocarioforms, and Bacillus spp. (Hoffman 1989).

It is known that cave bacteria play a vital role in the formation of karst, the quality of aquifer waters, bioremediation, and certainly in primary production for the support of the cave ecosystem (Hoffman 1989). In Mammoth Cave, Kentucky, Rusterholz and Mallory (1994) used a $p$-iodonitrotetrazolium violet (INT) staining technique which relies upon the uptake of INT by respiring cells and reduction of the compound to an insoluble dye which can be directly observed by bright-field microscopy. They measured bacterial respiration and concluded that over $50 \%$ of cells were actively respiring and that bacterial populations significantly contribute to nutrient cycling, degradation of complex compounds, and carbon flow in the cave environment. 
It has been known for some time that cave microorganisms may participate in the precipitation of minerals, either passively by acting as nucleation sites (Went 1969), or actively through the production of enzymes or substances that lead to precipitation by changing the microenvironment. Danielli and Edington (1983) observed that some bacteria isolated from the cave environment had the ability to dissolve carbonates. The appearance in some caves of moonmilk, a soft, white, plastic speleothem consisting of calcite $\left(\mathrm{CaCO}_{3}\right)$, hydrocalcite $\left(\mathrm{CaCO}_{3} \cdot \mathrm{H}_{2} \mathrm{O}\right)$, hydromagnesite $\left[\mathrm{Mg}_{5}\left(\mathrm{CO}_{3}\right)_{4}(\mathrm{OH})_{2} \cdot 4 \mathrm{H}_{2} \mathrm{O}\right]$, or huntite $\left[\mathrm{Mg}_{3} \mathrm{Ca}\left(\mathrm{CO}_{3}\right)_{4}\right]$ (Hill and Forti 1997), has been linked to the presence of bacteria (Canaveras et al. 1999). It is now known that some microorganisms participate in the dissolution of cave formations and cavern development by the production of acidic metabolic by-products (Northup et al. 2000; Engel et al. 2001).

Atlas (1981) determined that bacteria indigenous to soils are able to slowly degrade hydrocarbons under anaerobic conditions. It is now known that microbes participate in the bioremediation of groundwaters containing agricultural herbicides and pesticides (Amy et al. 1990), radionuclides, mobile metals, nitrates, and components of gasoline such as benzene, toluene, xylene, and ethylbenzene (Gounot 1994). Sulfur-oxidizing bacteria have been investigated from caves in four distinct karst systems throughout the world (Engel 1999). Microbes capable of metabolisms including sulfate reduction, methanogenesis, and dissimilatory Fe(III) reduction (Stevens and McKinley 1995) along with other microbes having unique metabolisms have been discovered in subterranean soil or sediment environments. A chemolithotrophic, arsenite-oxidizing bacterium isolated from a gold mine in Northern Australia was described by Santini et al. (2000). The bacterium utilizes arsenite $\left(\mathrm{As}^{\mathrm{III}}\left[\mathrm{H}_{3} \mathrm{AsO}_{3}\right]\right)$, a by-product of mining operations, and toxic to most living organisms, as the electron donor, oxygen as the 
electron acceptor, and either carbon dioxide $\left(\mathrm{CO}_{2}\right)$ or bicarbonate $\left(\mathrm{HCO}_{3}\right)$ as the carbon source. Microbes isolated from other novel environments are being used to bioremediate heavy metals such as copper and uranium (Sandaa et al. 1999; 2001). A large number of different plasmids encoding antibiotic and metal resistance were identified from the bacterial population of a deep-surface sediment on the Savannah River near Aiken, South Carolina (Jimenez 1990).

Studies in Lechuguilla Cave, New Mexico, a deep, gypsum and sulfur bearing cave, discovered at least five types of chemolithotrophs that appear to support populations of bacteria and fungi. Six distinct types of chemoheterotrophic bacteria including Caulobacter sp. and Silebria spp. were identified (Cunningham et al.1995). Sarbu et al. (1996) reported on a cave ecosystem in Movile Cave, Romania, known to be supported by in situ autotrophic production by chemoautotrophic bacteria. Fowler et al. (2001) have amplified and identified sequences belonging to a lithotrophic Nitrospira and relatives of the genus Acidobacterium from sediments in Mammoth Cave, Kentucky. Stevens and McKinley (1995) reported an anaerobic, lithotrophic microbial ecosystem, termed (SLiME) within a Columbia River Basalt aquifer. These examples imply that in at least some cave ecosystems, chemolithotrophic bacteria fill the same niche as photoautotrophs in surface waters. While chemolithoautotrophs continue to be discovered in the cave environment (Engel et al. 2001, Cunningham et al. 1995, Stevens and McKinley 1995), many cave bacteria are classified as heterotrophic and organic carbon sources are often limited in the cave environment. Conclusions from that study were that deep subsurface microbes are thriving in some of the earth's most oligotrophic environments.

Isolated in the depths, microbes have adapted with very slow rates of reproduction and 
exotic metabolisms (Kerr 1997). Cave microbes, with unique abilities, already have proven important in many ways. Subterranean microorganisms possess unique metabolic abilities of ecologic and potential economic importance. Subsurface bacteria are involved in the production of methane and hydrogen gases which provide alternatives to the use of fossil fuels. Scientists have already found underground bacteria with medical applications. Studies have been conducted to evaluate organisms which appear to produce compounds toxic to breast cancer cells or other antibacterial, antiviral, or antifungal properties (Nadis et al. 1997). Larry Mallory along with pharmacology researcher Jim Bigelow, have founded a corporation called Biomes to test the disease fighting capabilities of cave organisms and their by-products (Bigelow 1998).

Cave bacteria may be important in our understanding of evolution and in predictions regarding the possibility of life on other planets. Cave microbes from Lechuguilla Cave and several other sulfur caves in Mexico are being examined to determine how they utilize mineral sources such as sulfur, iron, and manganese to drive cell processes (Boston 1999). These organisms are being dubbed "earth analogs". Scientists in the NASA astrobiology program speculate that life forms on sulfur-rich Mars in a warmer, wetter time may have survived in an evolved form by migrating underground (Boston et al. 1992, Boston 2001).

\section{DIVERSITY AND REGULATING FACTORS}

Diversity can be defined in a number of ways. Biodiversity is defined as the variety of different organisms occurring together in a biological community (Atlas and Bartha 1993). Liesack et al. (1996) define diversity as the number of different sequence types present in a habitat. This genetic diversity is a measure of the functional potential in a 
microbial community and provides the limits and abilities of a community to respond to disturbance.

Purvis and Hector (2000) point out that knowing the diversity of one place, group or time is in itself useless but comparable measures of diversity from multiple places, or over time can help answer questions about regulation of diversity and its maintenance. They also point out that the usefulness of these answers depends upon the selection of appropriate measures of diversity.

The regulation of species diversity in general and in specific environments has been the topic of many studies. Connell and Orias (1964) discussed some of the classical theories on regulation of species diversity. Those theories included 1) the number of species is regulated by the number of ecological niches, 2) the rigorousness of the habitat limits the number of species, and 3) time for establishment of equilibrium is necessary for increased species diversity (Wallace 1878, Fischer 1960). Connell and Orias (1964) instead suggested that species diversity is limited by stability of the environment and energy flow through the community. Stability was defined by the amplitude of variation and the period of that fluctuation. Many studies support the fact that climate and disturbance strongly influence diversity and ecosystem functioning and that shifts in community structure can result in impacts on ecological processes (MacGillivray et al. 1995, Wardle et al. 1997, Jones et al. 1997).

Connell and Orias (1964) predicted that greater species diversity would accompany A higher production of organic matter and/or greater stability. Given the same gross primary production, a community in a more stable environment will exhibit more diversity. In systems of greater stability, less energy is required for maintenance and can therefore be channeled into production. In two systems with equal energy input, 
increased stability should lead to faster growth, decreased age of sexual maturity, larger individuals, greater production of young, and eventually greater population size. The universal occurrence of regulation in living organisms implies that metabolic processes are better carried out under relatively constant conditions (Connell and Orias 1964).

Moderate disturbance has been shown to increase diversity in some plant populations (Connell 1978, Huston 1979). The intermediate disturbance hypothesis states that diversity will be highest at sites that have had an intermediate frequency of disturbance that prevents competitive exclusion and will be lower at sites that have experienced very high or very low disturbance frequencies. The activity of bacterial predators, including grazers and viruses, may fall into this category and can impact bacterial diversity by reducing populations of dominant types, allowing for the proliferation of less competitive bacteria, thus increasing diversity.

There are also situations in which the environment and community can be very stable and yet diversity is limited by low input of energy, water, or nutrients, or by absolute space. Even when productivity is high, if much of the energy fixed by the primary producers is removed from the system, few consumers can be supported (Margalef 1963).

In addition to the stability of physical characteristics in an environment, food web complexity and feeding strategies have also been studied as determinants of ecosystem stability. MacArthur (1955) suggested that complexity of the food web is a good measure of community stability. Therefore, a small number of species each eating a wide variety of other species, could have the same community stability as a large number of species each with a fairly restricted diet. This indicates that a community composed of species with generalist feeding strategies would be more genetically diverse. 
In an attempt to apply previous diversity theories to the cave ecosystem, Culver (1970) compared caves to island ecosystems. Wilson (1961) found that the number of species of endemic ants on an island was directly proportional to the size of the island and the distance from "source" areas. What Culver (1970) concluded was that the quantity of organic matter did not increase diversity of the macroinvertebrate populations studied. Species diversity did not increase with length of the cave (a measure of spatial heterogeneity). The only factor investigated which seemed to influence species diversity in the cave system was that caves which flooded exhibited less diversity than caves which did not flood. Culver (1970), also determined that caves were more than collecting basins for macro-organisms washed in from the surface environment which agrees with those regarding the presence of microbes in cave environments.

Studies of microbial diversity in natural environments support the idea that diversity decreases with environmental stress and perturbation (Atlas et al. 1984). Atlas et al. (1991) found reduced genetic diversity in bacterial soil communities exposed to the herbicide 2,4,5-T (trichlorophenoxyacetic acid) compared to those in untreated soils. Nakatsu et al. (2001) found lower bacterial diversity in soils contaminated with polyaromatic hydrocarbons (PAH) than in uncontaminated soils. Previous studies involving culture techniques for cave bacteria revealed lower diversity in caves which were hydrologically open or directly stormfed caves than those with diffuse input (Gillieson 1996).

Increased input of organic matter does not lead to increased microbial diversity in soils. While there is great diversity in soil microbial communities, many indigenous soil microbes are classified as oligotrophic and many copiotrophic species (those adapted to high nutrients) do not appear to survive in the soil environment (Stotzky 1997). A study 
in Mammoth Cave, Kentucky (Rusterholz and Mallory 1994) supported earlier observations by Horowitz et al. (1983) that copiotrophic bacteria (those adapted to high nutrients) are less nutritionally diverse than those from oligotrophic environments. Studies of oligotrophic soil environments have revealed higher genetic diversity than in comparable surface habitats (Torsvik and Ovreas 2002). Torsvik et al. (1996) determined that agricultural management and pollution can decrease bacterial diversity in spite of an increase in bacterial biomass. They studied microbial diversity of communities in soils and sediments of Western Norway and concluded that quantity of organic matter (energy) was not related directly to microbial diversity. Instead, heavily polluted sediments had reduced diversity compared to pristine sediments, attributed to a decrease in the physiochemical complexity of the habitat.

Particle size, along with mineral composition, salinity, $\mathrm{pH}$, temperature, water content, nutrient availability, and geographical, geological, and anthropogenic influences, determine the ecological niches available for microbial survival in the soil environment. High microhabitat variation created in the soil environment by physical or chemical gradients, differences in nutrient availability, and interaction between microbes including the production of bacteriocides and antibiotics, can create boundries between related populations leading to genetic polymorphism.

Particle size distribution determines the surface area and interstitial spaces available for bacterial growth and interaction with the aqueous environment (Zhou et al. 2002; Sessitch et al. 2001). Hydrogen ion concentration affects the solubility, availability, and toxicity of mineral nutrients and heavy metals. It can influence physiological, morphological, and metabolic response of microbes, and can lead to species composition shifts. Sessitch et al. (2001) used tRFLP and sequencing of 16S rDNA clones to compare 
bacterial community structures in different particle size fractions. They determined that microbial community structure was significantly affected by particle size, yielding higher diversity of microbes in small size fractions than in coarse size fractions. An analysis of the structural similarities of microbial decomposer communities in sediments from a Lake Erie wetland and a small woodland stream utilizing whole community DNA-DNA hybribizations (Yeager and Sinsbaugh 1998), determined that microbial diversity increased as particle size decreased. Cluster analysis of hybridization scores partitioned the communities into two groups: one associated with the 500, 250 and $125 \mu \mathrm{m}$ fractions and a second with the 63 and $38 \mu \mathrm{m}$ fractions.

While sediments may be considered as soil environments, a comparison of soil and sediment bacteria by thermal melt profiles (Torsvik et al. 1996) revealed different $\mathrm{G}+\mathrm{C}$ composition of these two environments. Sediments contained $35-55 \% \mathrm{G}+\mathrm{C}$ in the sequences studied, while soils averaged $57-59 \%$. Based on these thermal melt profiles and reassociation rates, they concluded that sediments contained an even higher diversity than those of soils and have a different community structure.

Liesack et al. (1991), define community structure as including quantitative information on the number of individuals of different taxa or physiological groups. Evaluating community structure may involve using target groups of organisms to detect a shift in populations due to some environmental change. It could also involve the identification and/or quantification of microbes present in the sampled community. The information may be used to track genetically modified bacteria in the environment, to monitor response to reclamation or disturbance in soil or sediment, to assess health or fertility of agricultural soils, or to provide a baseline for the unknown diversity of microorganisms found in various habitats. 
Ranjard et al. (2000) state that the study of structural and functional diversity in soil bacterial communities and their response to disturbance is essential. Shifts in community structure of soil bacteria have been documented in response to both natural and human influences (Felski et al. 1998; Nusslein and Tiedje 1999; van Waasbergen et al. 2000) Changes in community profiles among soils with different levels of disturbance have also been documented by Axelrood et al. (2002) and Smit et al. (1997).

According to Torsvik (1996), knowledge about bacterial community structure and diversity is essential in understanding the relationship between environmental factors and ecosystem function. Ninety-five percent of experimental studies support a positive relationship between diversity and ecosystem functioning (Schwartz et al. 2000) Community structure presumably plays an important role in adapting to changing environmental conditions. Bacteria in soils play a key role in biogeochemical cycling of carbon, nitrogen, sulfur, iron, nickel, and mercury among others. They also are involved in energy and nutrient exchanges within the soil matrix. Our knowledge of the types and distributions of microbes in the environment is rudimentary and surveys of microorganisms in the environment are necessary for our understanding of biological diversity and the evolutionary processes which have led to it (Barns et al. 1994).

Organisms with limited distribution or localized populations are at highest risk of extinction. Cave environments and isolated cave pools offer a unique environment in which to study microorganisms and the influence of stress or environmental change on microbial diversity, community structure, and function. Investigations of subsurface environments have revealed a high phenotypic and genotypic diversity of microbes in soils, sediments, and waters (Torsvik et al. 1991, Dunbar et al. 1999, Kuske et al. 1997, 
Felske et al. 1998). Also, these subsurface bacterial communities have been found to differ from those found in similar surface substrates (Amy et al. 1992, Bone and Balkwill 1988).

\section{MEASURING MICROBIAL DIVERSITY}

Traditionally, diversity is based upon the number of species present (species richness) and the relative abundances of those species (species evenness). It is difficult to apply this diversity concept to bacteria for several reasons. First, the application of traditional diversity indices require a clear definition of "species" which is difficult to apply in microbial studies (O’Donnell et al. 1994; Stackebrandt and Goebel 1994; Watve and Gangal 1996). Presently, bacterial taxonomists have agreed to define a species on the basis of a DNA-DNA similarity greater than 70\% (Schleifer and Stackebrandt 1983, Wayne et al. 1987). Secondly, methods available for studying microbes do not allow for the easy simultaneous counting and identification of bacteria present in any natural environment, a common methodology for ecological studies of macroorganisms. It is widely accepted that only a small fraction of bacteria in the environment are culturable. While traditional methods of studying microorganisms in soils or sediments involve isolation and selective culture, the percentage of soil organisms estimated to be cultured is $0.3 \%$ (Amann et al. 1995). Cultured bacteria for the study of microbial diversity in soils and sediments included only $0.1-1 \%$ of the active cells counted by fluorescent staining (Torsvik et al. 1996). Finally, most environmental bacteria are undescribed and therefore difficult to assign to a taxon. Frequently, this problem is addressed by replacing the traditional "species" with clusters of isolates called phenotypes, organizational taxonomic units (OTUs), or biotypes. These groups have no phylogenetic 
meaning but are units which may be used to characterize and compare populations and communities (Torsvik et al. 1996).

A number of papers have been published regarding diversity and community structure of microbes in various soil and sediment environments (Axelrood et al. 2002, Barns et al. 1994, Clegg et al. 1998). Many of these studies employ the analysis of total community DNA or subsets of the total extracted DNA (Dang and Lovell 2000; Holben et al. 1988; Jimenez 1990; Liu et al. 1997; Martinez-Murcia et al. 1995). Diversity in microbial communities may be determined using phenotypic or genotypic approaches and may involve analyses of taxonomic diversity, physiological or functional diversity, species richness and/or evenness, and may or may not attempt to identify the microbes.

Total community DNA extracted from the environment can be analyzed by reassociation rates of denatured DNA, the use of thermal melt profiles to determine base composition $(\% \mathrm{G}+\mathrm{C})$, or by direct cloning and creation of clone libraries for sequencing or profiling. Probes for genes encoding metabolic processes or phylogenetic probes for specific groups of microbes can also be utilized (Herrick et al. 1993).

The use of polymerase chain reaction (PCR) to amplify particular genes from the total community DNA for the creation of clone libraries or other analyses is a common technique. However, the identification of minority populations utilizing clone libraries remains a problem. Cells occurring at $10^{2}-10^{4}$ in a population of $10^{8}$ cells per gram of soil would require an analysis of $10^{4}-10^{6}$ clones to recover a representative of this group (Rheims et al. 1996). Many studies of bacterial diversity, however, are based upon clone libraries (Angert et al. 1998, Axelrood et al. 2002, Dunbar et al. 2002, Engel et al. 2001, Schmidt et al. 1991, Smit et al. 1997).

In the 1970s, Woese and colleagues described the use of comparative ribosomal RNA 
gene analysis for phylogenetic studies (Fox et al. 1977, Sogin et al. 1972, Woese et al. 1975). This work provided an evolutionary basis for prokaryotic taxonomy and led to the three-domain taxonomic organization (Woese and Fox 1977). The gene coding for the $16 \mathrm{~S}$ subunit of the ribosomal gene (16S rDNA) makes a good molecular and phylogenetic marker because it has regions which are highly conserved among members of all three domains of life and regions of variability which allow distinction among even very closely related taxa (Woese 1987, Ludwig and Schleifer 1994). Pace et al. (1985) were the first to suggest the use of the 16S rDNA molecule as a molecular marker for the study of microbial populations in their natural environment. The development of methods for analysis of rRNA molecules from environmental samples has provided a culture-independent means to examine diversity of microorganisms in natural habitats (Barns et al. 1994, Giovannoni et al. 1990, Pace 1997, Ward et al. 1992).

A number of techniques to screen communities have since been developed, many of which utilize PCR to amplify various regions of the rRNA gene. Profiling microbial communities by PCR-based, cloning-free methods targeting the 16S subunit of rDNA to identify the numerically dominant species in ecosystems (Muyzer et al. 1993) has grown in popularity since its inception. Preliminary steps include the isolation of community DNA and the PCR amplification of 16S rDNA from the community DNA template using either universal primers for all bacteria or specific primers targeting smaller subsets of the community. At this point, various approaches differ in the analysis of PCR products.

Besides the creation of clone libraries for sequencing, several methods exist for utilizing the community DNA once it is extracted and amplified by PCR. Restriction patterns of combined amplicons or of clones may be compared. These patterns can be created by restriction fragment length polymorphism (RFLP), terminal restriction 
fragment length polymorphism (tRFLP), amplified fragment length polymorphism (AFLP), the fluorescent version of AFLP (fAFLP), or amplified ribosomal DNA restriction analysis (ARDRA). Temperature gradient gel electrophoresis (TGGE) and denaturing gradient gel electrophoresis (DGGE) methods may be used to reveal nonrestriction based polymorphisms and involve increasing chemical or thermal gradients to denature and separate amplified DNA molecules.

Nakatsu et al. (2000) investigated the use of DGGE to separate PCR amplified products from the rRNA gene of soil communities. Because of the high estimated number of bacterial species in soils, it was unclear if this method could provide qualitative or quantitative information about soil microbial community composition. They found a high diversity of bacterial PCR amplification products in all soils tested as indicated by the number of bands in the DGGE pattern. Conclusions were that this is a useful method for initial ecological studies to distinguish communities from different ecosystems and to determine the presence of dominant phylotypes (Nakatsu et al. 2000). Nakatsu et al. (2000) demonstrated that the presence of only a few dominant species will produce profiles that can distinguish between soils with basically the same diversity or soils with different relative proportions of populations in the communities.

Both ARDRA and tRFLP analyses detected differences in the culturable portion of bacterial communities when untreated soils were compared to those treated with 4,6dinitroorthocresol (DNOC); (Rousseaux et al. 2003). ARDRA was utilized for assessing the effects of copper contamination on soil microbial community structure and diversity (Smit et al. 1997). Greater diversity was observed from 16S clones than from cultured isolates. They also found distinct differences between contaminated and noncontaminated soils. Marsh et al. (2000) used T-RFLP with the restriction enzyme HhaI 
to demonstrate the similarities between two profiles from soil communities and the different profile of activated sludge. They stated however, that the results of this study are subject to all of the caveats routinely applied to molecular approaches that are dependent on efficient extraction of community DNA and PCR amplification of a target gene. In addition, when analyzing restriction patterns, care must be taken to assure that restriction digests are complete and specific and should include the amplified product from a well-characterized isolate in representative digestions (Marsh et al. 2000).

When using DNA for community analyses, the biases associated with the chosen methods must be considered. Bias has been documented with each step of molecular techniques associated with community analysis. In order to assure that the community DNA will be an accurate representation of the diversity present, appropriate methods for extraction, amplification, analysis, and interpretation of results for a particular sample must be determined.

There has been concern regarding the preferential amplification or representation of the community using PCR (Reysenbach et al. 1992). Amplifying the 16S subunit of rRNA genes can lead to a bias based on the unequal copy number of ribosomal genes in various species (Farrelly et al. 1995). This problem is not easily solved as many environmental bacteria have unknown copy numbers of ribosomal genes. Pure culture studies need not consider the effects of genome size and rrn gene copy number as a potential source of bias. However, when comparing microbial community structure, these limitations should be addressed. This difference in ribosomal gene copy number creates limitations for using band intensity as an indication of cell numbers. Using DGGE, Muyzer et al. (1993) demonstrated that dilution of template to extinction did not affect the pattern of major bands. Felske et al. (1998) reported that the relative 
abundance of products in complex mixtures did not change upon amplification. Using kinetic PCR, Felske et al. (1998) determined that even the highest dilutions containing a mixture of species represent the dominant bacteria in a homogeneous grassland soil. However, they caution against using information from PCR based studies to infer species richness and evenness.

Farrelly et al. (1995) cautioned against drawing conclusions from molecular ecological studies involving the PCR amplification of $16 \mathrm{~S}$ rDNA using DNA extracted from environmental samples. Sequence heterogeneities from PCR or within the 16S operon in same species may lead to misinterpretation of diversity information. When separating PCR products for analysis, two species can occupy the same band and similarly, one species may form two or more bands (Nubel et al. 1996). In addition, it is common for one DGGE band to carry more than one sequence. Many of the difficulties in interpreting data are common to all PCR-based analyses.

Conclusions from a study performed by Kuske et al. (1998) were that optimization of soil template concentration was necessary for achieving the best PCR detection sensitivity. Of four different soils tested, optimal template amount for soils varied greatly between $100 \mathrm{pg}$ and $1 \mathrm{ng}$ per reaction mixture. Primer selection can also introduce bias during PCR amplification. Primer pair 519F-1406R yielded products in the predicted proportions when testing a defined mixture of two different 16S rDNA types while 27F-338R resulted in a strong bias (Suzuki and Giovannoni (1996). Nakatsu et al. (2000) found that when comparing DGGE profiles, patterns of the same soil differed when different primers were used for PCR amplification.

In addition, chimeric sequences may be formed, leading to sequencing errors or mismatches when comparing experimental data to database sequences (Kopczynski et al. 
1994). Hybrid rDNA, formed from rDNA of different origins during PCR amplification of mixed population DNA, has also been documented by Liesack et al. (1991). The formation of these chimeric sequences can arise when partially elongated DNA products formed in one cycle of PCR serve as primers in another round of amplification with template from a different organism (Barns et al. 1994). Using chimeric sequence checking programs, chimeric sequences have been detected in clone libraries at ranges of 2/113 up to 2/9 (Liesack et al. 1991; Kopczynski et al. 1994). The formation of chimeric sequences is dependent upon the number of PCR cycles and the presence of low molecular weight fragments (Wang and Wang 1996).

While many current papers published on microbial communities do utilize direct extraction and PCR to assess diversity in bacterial communities, some concerns and limitations remain for both PCR-based community studies in general and for specific methods. These difficulties have been discussed in considerable detail (Ogram 2000, Winzengerode et al. 1997, Zhou et al. 1996) and include concerns regarding preferential cell lysis, extraction of DNAs, and amplification bias during PCR. Three things must be considered when evaluating DNA for diversity analyses: total DNA yield, cell lysis efficiency, and purity.

It has been documented that the extraction of nucleic acids is a crucial step in evaluating bacterial communities as some microorganisms are not easily lysed .Methods of extraction and purification are certain to influence the DNA that is obtained. The nucleic acids obtained will affect the microbial community assessment. Lsis and extraction bias may be introduced because some cells are more difficult to lyse than others. Traditionally, cells found in soil are difficult to lyse. Spores are also resistant to lysis. Preferential lysis (Picard et al. 1992) and extraction (Liesack et al. 1991, Ogram et 
al. 1988, Tebbe and Vahjen 1993) have been noted in a number of studies.

Past studies of bacterial diversity have utilized either direct lysis procedures or lysis and extraction of the DNA from cells after separation from the soil matrix. Miller et al. (1999) called for new tools to rapidly compare the nucleic acid diversities of extracts in order to better estimate the effectiveness of DNA extraction protocols. Selection of an appropriate DNA extraction and purification procedure from among the procedures which have been described to date remains a major problem in the application of molecular techniques to studies of soil and sediment microbial communities (Miller et al. 1999).

A number of studies have compared extraction and purification methods for community DNA from a variety of soils and sediments (Tsai and Olson 1992, Krsek and Wellington 1999, Kuske et al. 1998, Miller et al. 1999, Leff et al. 1995, Zhou et al.1996). Krsek and Wellington (1999) compared different methods for the isolation and purification of total community DNA from soil. They reported that the highest yield and purity of DNA, as measured by absorbance spectrophotometry, was achieved by a combination of lysozyme, sodium dodecyl sulfate (SDS), and bead-beating. A comparison of various methods of extraction by Miller et al. (1999) also found that the highest yield of DNA from a variety of soil and sediment samples was obtained by a bead-beating method with sodium dodecyl sulfate (SDS) as a chemical lysis agent. Kuske et al. (1998) demonstrated that bead mill homogenization in combination with hot detergent was most effective for lysis of bacterial spores. Any increase of EDTA or ionic strength of the buffer used resulted in increased yields but lower purity of the DNA.

Leff et al. (1995) compared various methods for extraction of DNA from stream sediments. Extraction methods tested yielded between 0.06 and $0.29 \mu \mathrm{g}$ of DNA/gm 
sediment. The Jacobsen method (Jacobsen et al. 1992) produced extracts with the lowest yields but those samples had the lowest levels of contamination. The Ogram method (Ogram et al. 1988) yielded the most DNA, but produced smaller sized DNA fragments. Failure to obtain DNA by some methods was attributed to the adsorption of DNA by soil particles promoted mainly by bivalent cations. High absorbance values at $230 \mathrm{~nm}$ wavelength indicate contamination with phenolsor other aromatic compounds, or plant compounds such as tannins, humic, and fulvic acids. Absorbance at $280 \mathrm{~nm}$ indicates contaminants such as proteins or RNA, while absorbance at $325 \mathrm{~nm}$ indicates contamination by particulates or dirty cuvettes. Leff et al. (1995) evaluated several extraction methods and all gave A260/A280 ratios between 0.99 and 1.21. Zhou et al. (1996) obtained A260/A280 ratios from 1.17 to 1.35.Zhou et al. (1996) compared yield and purity of DNA extracted from soil and subjected to CTAB, PVPP, or both compounds. Ratios were calculated using absorbance readings at $260 \mathrm{~nm}, 230 \mathrm{~nm}$, and $280 \mathrm{~nm}$. Absorbance at $230 \mathrm{~nm}$ is an indication of contamination with phenols, humics, and other organic acids. Absorbance at $280 \mathrm{~nm}$ usually indicates proteins and other cellular components in the extract. Zhou et al. (1996) found that absorbance ratios of (A260/A280) ranged from 1.17 to 1.35 while ratios of (A260/A230) were between 0.72 and 0.91 . Highly purified DNA will have calculated values for both ratios between 1.82.0. All methods evaluated by Leff et al. (1995) gave (A260/A280) absorbance ratios between 0.99 and 1.21. Krske and Wellington (1999) found no positive effect on DNA purity with the use of PVP or PVPP. In addition, PVP and PVPP were associated with a decreased yield of DNA. However, using a commercial humic acid preparation, they demonstrated that lysozyme was effective in the removal of humic acids.

Most current procedures for DNA extraction from soils and sediments are based 
on direct lysis from the cell matrix rather than separating the cells from the soil particles prior to extraction of the DNA (Ogram 1998). Direct lysis from soil particles yields more heterogeneity than samples from which the cells have been removed from soil particles before lysing. However, direct lysis extracts contain DNA from both prokaryotes and eukaryotes and includes even naked DNA from the environmental sample. Other studies indicate that the direct lysis technique for DNA extraction consistently produces samples with greater amounts of contaminants than other methods. Krske and Wellington (1999) found that ex situ lysis yielded $60 \%$ less DNA and was more contaminated with humic a acids than cells lysed in situ.

Conclusions from comparative extraction and purification studies were that in-situ extractions produced higher quality and quantities of DNA. Also, mechanical methods of disrupting cells in conjunction with chemicals were more effective than chemicals alone. This was due to the tight bonds between cells and soil particles. Bias due to lysis can be minimized by carefully choosing lysis procedures to include a mechanical process while protecting against excessive shearing. Careful buffer selection can minimize adsorption of DNA (Krske and Wellington 1999). The selection of buffer must be suited to the particular sample and the use of PVP, PVPP, or CTAB will decrease yields of DNA although CTAB less than the others (Kreske and Wellington 1999, Zhou et al. 1996). Methods for extraction, purification, and amplification must be assessed for specific samples. Proper amplification procedures should include careful selection of primers (Rainey et al.1994, Liu et al. 1997), and careful determination of conditions for elongation and annealing. However, even after careful selection of sample size, extraction/purification methods, and amplification conditions, many DNA extracts from environmental samples yield no PCR product. This is often attributed to inhibiting 
substances co-extracted with the DNA. Common inhibitors determined from a variety of samples are urea, hemoglobin, heavy metals, detergents, glove powder, bacterial debris and denatured proteins. PCR can be inhibited by compounds inherent in soils such as humic acids, fulvic acids, phenolics and other organic compounds. Inorganic molecules such as calcium, magnesium, and iron may also present problems. In addition, many samples which defy amplification by PCR have inhibitors which are unidentified (Wilson 1997).

There have been many studies about the inhibition of PCR due to compounds found in DNA extracts. These have included studies on food and dairy products (Ogunjimi and Choudary 1999, Bickley et al. 1996, Wadowsky et al. 1994), clinical specimens (Konet et al. 2000), water and sewage (Abbaszadegan et al. 1993, Tsai et al. 1993), and various soil and sediment samples (Berthelet et al. 1996, Bruce et al. 1992, Guthrie et al. 2000, Tsai and Olson 1992).

In a study by Bickley et al. (1996), calcium ions were identified as a major source of PCR inhibition when amplification of Listeria monocytogenes from samples containing more than 5\% milk failed. Substances such as salt, calcium, and polysaccharides can block detection of microbes in processed food by inhibiting PCR (Coghlan 1999).

Inhibition of PCR for the determination of Bordetella pertussis from nasopharyngeal swabs was overcome by collection with Dacron swabs instead of those of calcium alginate (Wadowsky et al. 1994). Konet et al. (2000) reported that the inhibition of RTPCR for the detection of foot-and-mouth viral particles from patient serum could not be attributed to any investigated parameters. However, they pointed out that investigated parameters did not include calcium, which can be found in serum.

Although inhibitors in many samples remain unidentified, there have been a 
number of mechanisms for inhibition that have been identified. These mechanisms may be grouped into three broad categories. The first is the inhibition of cell lysis. This can be due to cellular characteristics or to substances which prevent cell lysis. High concentrations of salt in selective media has been implicated as a factor in the inability to lyse cells for detection of Listeria (Bickley et al. 1996). In other situations, it has been noted that proteolytic enzymes and denaturants can be responsible for the degradation of lytic enzymes before they have time to work.

The second way in which inhibitors may act, is to degrade or sequester freed DNA. In studies where successful cell lysis has been documented, there is evidence of nucleic acid degradation after release from the cell. It has been reported that Staphylococcal thermonuclease is not destroyed during thermal cycling, and that it is able to hydrolyze both genomic and primer DNA during amplification reactions (Wilson et al. 1991, 1993, 1994). Sequestration of primer or target DNA can also prevent PCR amplification. One example is short strands of ssDNA, caused by excessive shearing, that bind to target sequences preventing the binding of primers. It is thought that glove powder may act in a similar way since silica and diatomaceous earth is frequently used to bind DNA during extraction. Humic acids and blood proteins also likely act to block interaction between target template and polymerase. It has been demonstrated that pure humic acid can inhibit PCR reactions at concentrations as low as $10 \mathrm{ng}$.

Thirdly, and related to the second mechanism, inhibitors may bind or degrade the polymerase itself. Cheese proteases have been shown to inactivate Taq polymerase and phenolic compounds from either cells or the extraction procedure can bind the polymerase.

In spite of the limitations, Bruggeman et al. (2000) concluded that profiles of bacterial 
communities generated by PCR-based methods are a reasonable estimation of the dominant in situ community structure. When appropriate methods are chosen, and PCR is successful, the rRNA sequence studies of environmental organisms most likely identify the abundant organisms in the habitats studied, and therefore, account for the organisms that participate significantly in the maintenance of the communities (Hugenholtz et al. 1998).

Limitations are also presented by the methods of community comparison. Many of the methods utilized for microbial community analysis involve the classification of bacterial fragments or sequences into groups. In order to identify groups or OTUs, a cutoff for similarity must be used. These cutoff values have been arbitrarily and inconsistently used in the field of microbial ecology (Watve and Gangal 1996). In many cases, microbial ecologists have borrowed diversity indices from plant and animal ecologists. Indices such as the Shannon index and Simpson's index continue to be used in spite of the acknowledgement that they are inappropriate for bacterial communities (Staley 1980, Torsvik et al. 1998). Watve and Gangal (1996) suggest a meandissimilarity based index without any attempt to define a species provides a statistically sound measurement of bacterial diversity. Nakatsu et al. (2000) determined the relatedness of microbial communities using Sorensen's index of similarity (Cs) and DGGE band patterns of soil communities. The index formula uses the number of bands common to the two communities, divided by the number of bands in both samples to create a coefficient of similarity (Nakatsu et al. 2000).

Molecular methods for microbial ecology will continue to expand our understanding of bacteria in their natural habitats (Ranjard et al. 2000). PCR has been demonstrated to be a useful test for the presence of specific bacteria in a variety of 
environments (Steffan and Atlas 1988; Holben et al. 1988; Herrick et al. 1993). In addition to detecting known species of bacteria, these techniques can be used to create or add to existing phylogenetic trees or to assess microbial diversity (Hugenholtz et al. 1998, Rheims et al. 1996, Ogram 2000, Stahl 1996). Many of the previous studies of microbes in subterranean systems were dependent upon culture techniques (Cunningham et al. 1995, Groth et al. 1999, Laiz et al. 2000, Rusterholz and Mallory 1995). Other studies have utilized ribosomal sequences to identify unique bacteria in the cave environment (Stevens and McKinley 1995, Fowler et al. 2001). Rheims et al. (1996) suggested that the usefulness of $16 \mathrm{~S}$ rDNA is in determining the presence or absence of similarities in the phylogenetic patterns of environmental samples of different origin. These methods are suitable for assessing the composition of microbial communities and to monitor changes in these communities over time. However, Amann (1995) stated that even the most complete rRNA study cannot substitute for the isolation and characterization of microorganisms in any environment. The development of a combination of molecular and culture techniques for studying activity of microbial populations, gene expression, and regulation of this expression in understanding the relationship between microorganisms and the environment was emphasized by Ranjard et al. (2000).

The most complete picture of microbial diversity will require a combination of methods including direct cell counts in addition to analysis by molecular and culture techniques. Widespread occurrence of environmental sequences belonging to the Acidobacterium division suggest that members of this group are ecologically important to many ecosystems, especially soil communities. Although many of these microbes remain uncultured, they have been clonally detected in analyses of soils with a wide range 
of chemical properties (Hugenholtz et al. 1998). There have been numerous studies investigating the phylogenetic overlap between organisms obtained by cultivation and organisms identified by direct amplification and cloning of 16S rDNA (Benlloch et al. 1995, Chandler et al. 1997, Pedersen et al. 1996, Stackebrandt et al. 1993, Suzuki et al. 1997, Wilson and Blitchington 1996). These studies have consistently demonstrated that the two methods generally sample different fractions of bacterial communities. Overlap between culture collections and 16S rDNA clone libraries ranged from no overlap (Benlloch et al. 1995, Suzuki et al. 1997) to as high as $41 \%$ of phylotypes being identified both in culture and in 16S rDNA clone libraries (Chandler et al. 1997, Wilson and Blitchington 1996). Other studies also demonstrate that different segments of the bacterial community are represented by culture and culture-independent methods (Felske et al. 1999; McCaig et al. 2001; Smit et al. 2001). Axelrood et al. (2002) found both similarities and differences in community members recovered from the same soil samples using a combination of cultivation and molecular methods. Muyzer et al. (1993) found that patterns generated by TGGE/DGGE from DNA extracted directly from rhizosphere soils had only a few bands in common with the patterns from the culturable portion of the community. The amount of overlap between culture collections and clone libraries appears to depend on several factors, such as the complexity of the environment being examined, the discrepancy between plate counts and direct counts, and the sample size of 16S rDNA clones (Dunbar et al. 1999). 


\section{RESEARCH AIMS AND HYPOTHESES}

Against the background of this knowledge base of microbial diversity and caves, this study evaluates the genetic diversity and bacterial community structure within cave sediments in the central Kentucky karst region compared to those of nearby surface stream communities using a combination of culture and molecular methods. The following two hypotheses were examined:

1. Genetic diversity in cave sediments will be higher than that of comparable surface habitats. Caves are described as a low nutrient environment. Previous studies of other soil environments described as low nutrient (containing oligotrophs) have revealed higher genetic diversity than comparable surface habitats. Other studies also support the idea that bacterial diversity decreases with environmental stress and perturbation (Atlas 1984). The stability of the cave environment would lead to the prediction that genetic diversity is higher in the cave environment.

\section{Bacteria in cave sediments will have unique community structures when compared to} those in nearby surface stream sediments. Since genetic diversity does not accurately measure any similarity in the species present, two communities with the same complexity could have anywhere from $0-100 \%$ of species in common (Griffiths et al. 1996).

Previous studies have shown many cave bacteria are also found in soils and surface sediments including actinomycetes, nocarioforms, and Bacillus spp.(Hoffman 1989). However, many previous studies involved culture techniques which revealed only those 
cave organisms culturable by methods utilized for comparable surface habitats.

Therefore, at least some of the apparent similarity in surface and subsurface microbes may be due to methodologies (Rusterholz and Mallory 1994). 


\section{METHODS}

\section{A. CHARACTERIZATION OF CAVES}

\section{STUDY SITES}

Sampling was performed between March 1999 and December 2002. Specific sample dates will be addressed with the associated methods. Samples were collected from two caves, Belt Cave (Figure 1) and Penitentiary Cave (Figure 2), in central Kentucky's karst region. Surface sites on Sinking Creek (GPS 3752'72"N 86²21'59"W) and Funks Run (GPS 3743'56.6"N 86²7.8'35"W) were also sampled for comparison (Figures 3 and 4). Belt Cave, in Hardin County, Kentucky (GPS 3743'64"N 8607'39"W) collects diffuse inputs and discharges as Funks Run, the first tributary to the Rough River (Figure 5). Penitentiary Cave is located in Breckinridge County, Kentucky (GPS 3751'89"N 86 22'06"W). The waters in Penitentiary Cave are also of diffuse origin (Figure 6). Land use in this area is predominantly agricultural as indicated by a USDA census (Figure 7). Both caves have a variety of underground streams (Figures 8 and 9) and drip pools (Figure 10) for sampling. These aquatic habitats provide refuge for a variety of obligate cave dwelling organisms. Penitentiary Cave has over 400 northern cavefish, more than recorded at any other site in the world (Pearson 2000). 
Figure 4: Sinking Creek sampling site

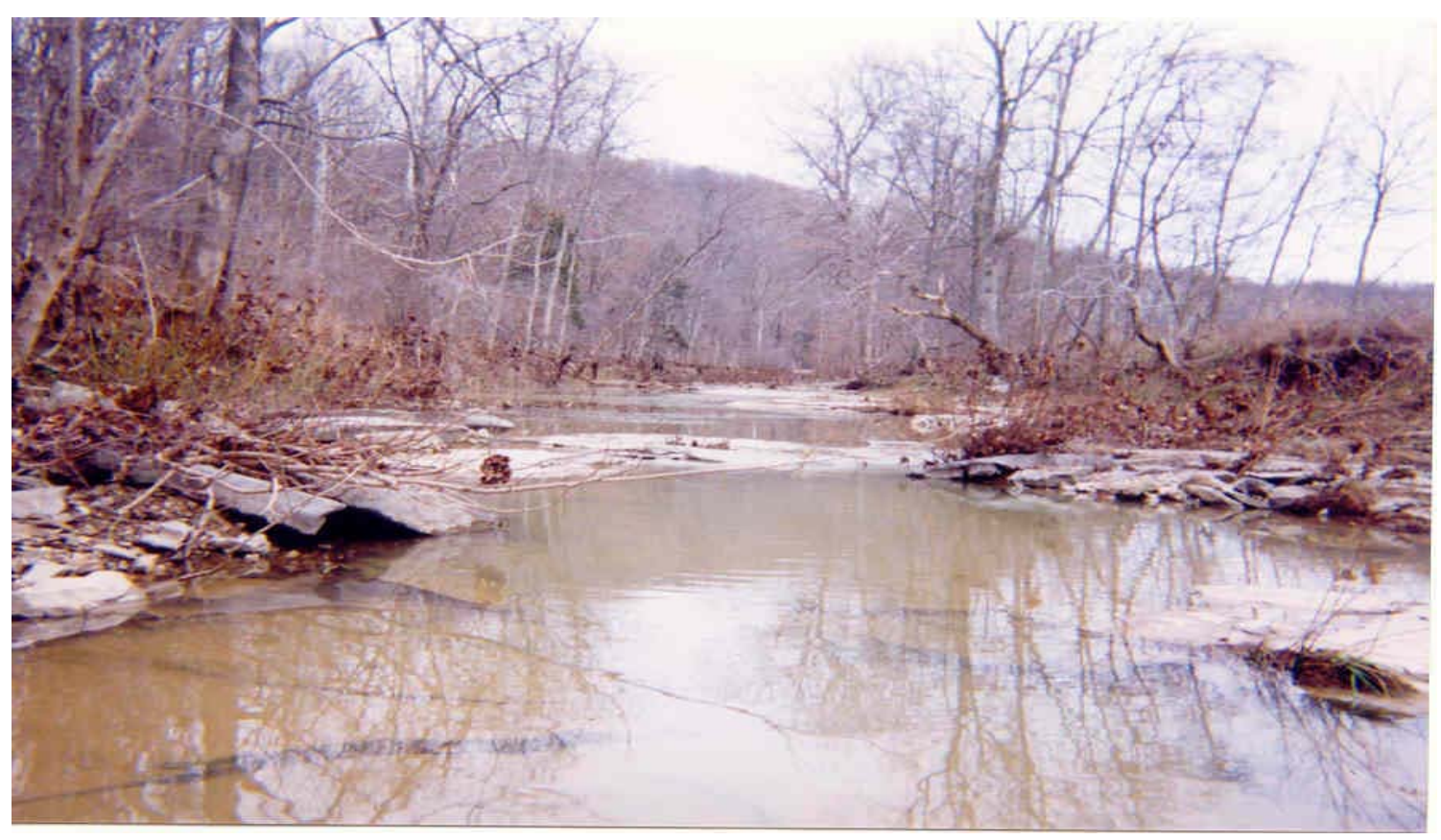

Legend: The Sinking Creek sampling site is located above the bridge on Webster-Clifton Mills Road. This photo was taken in December 2000. 
Figure 5: Funks Run sampling site

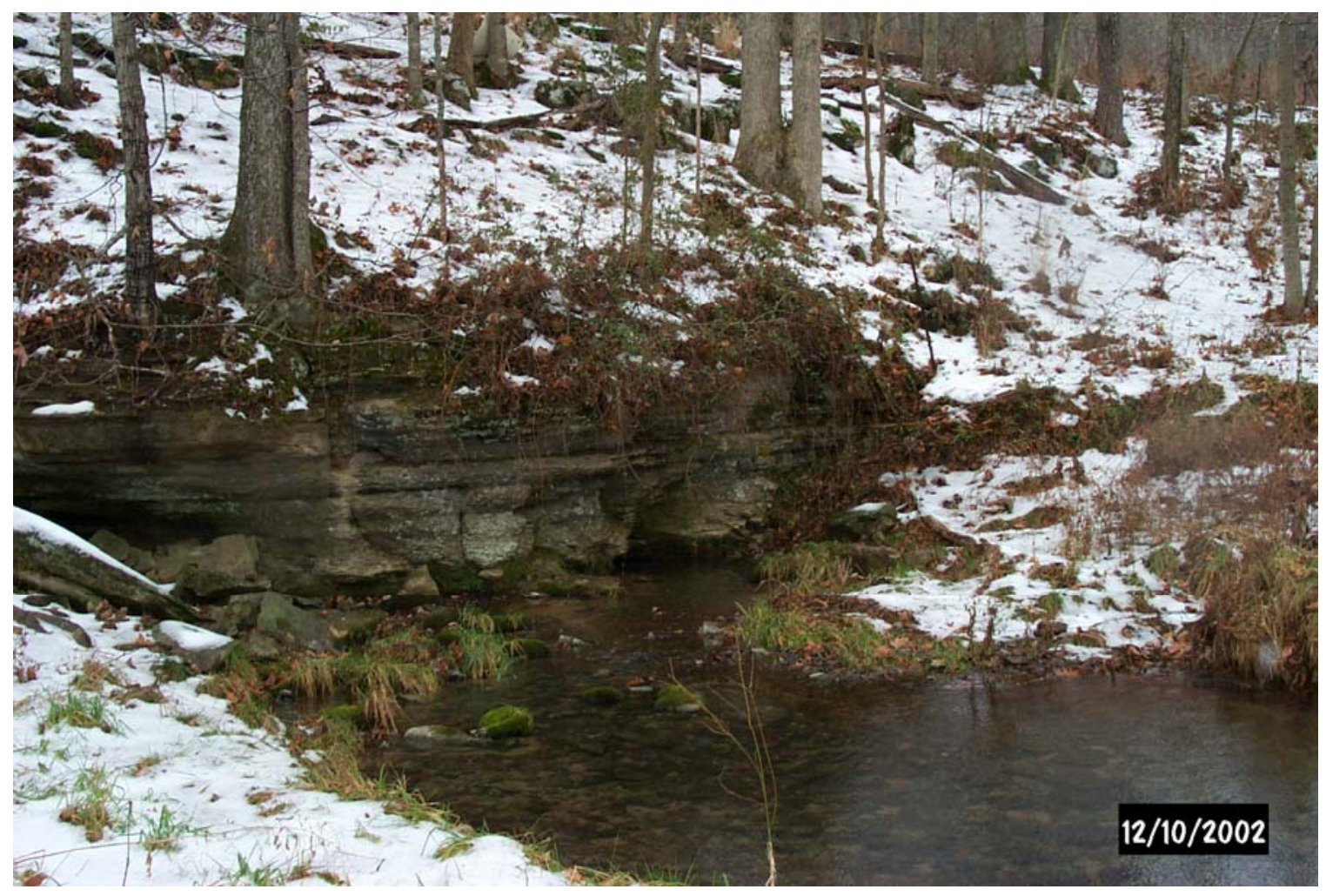

Legend: Headwaters of Funks Run emerging from Belt Cave, Hardin County, Kentucky in December 2002. 
Figure 6. Topographical map indicating the GPS coordinates and locations for the sampling sites in Hardin County, Kentucky.

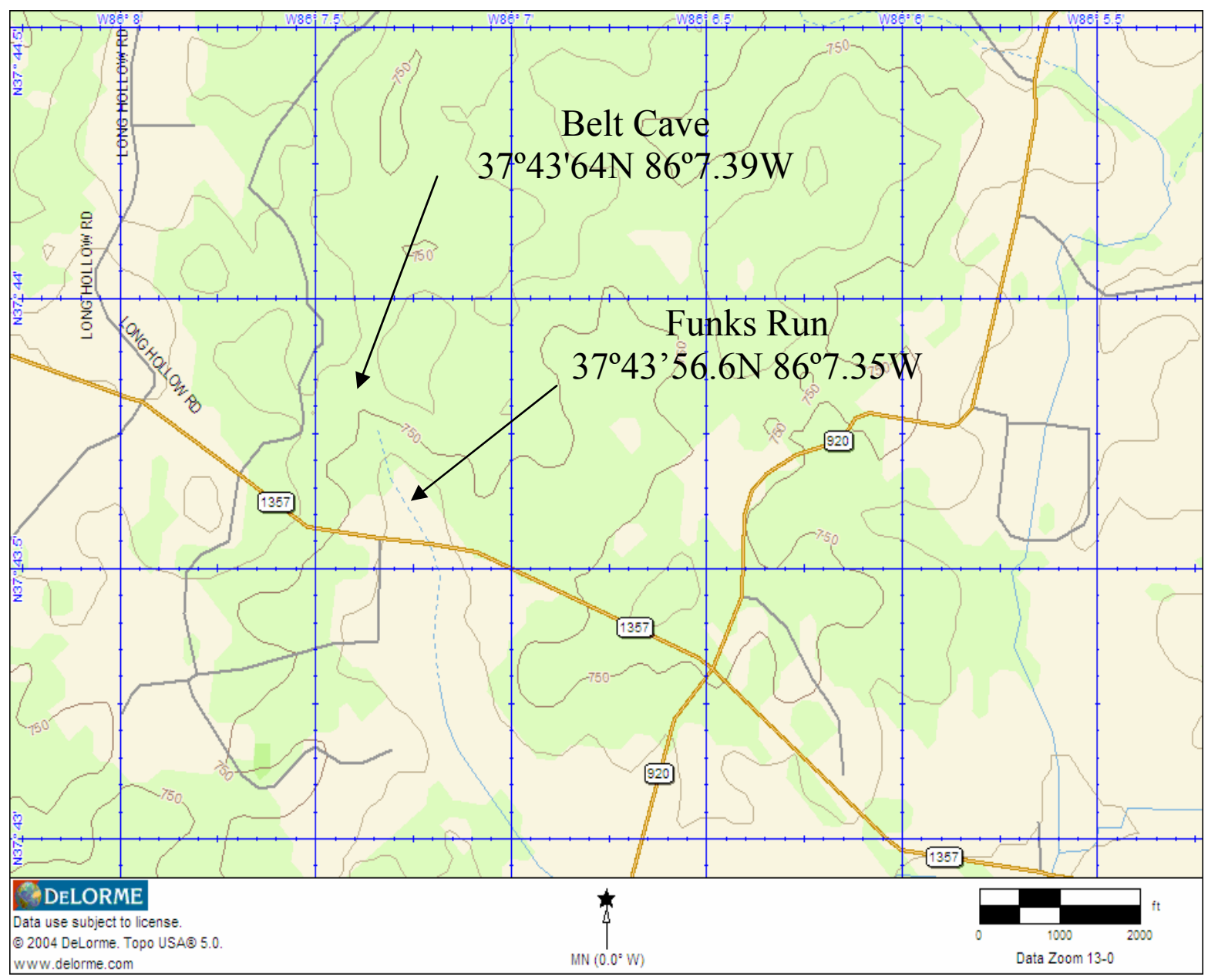

Legend: GPS coordinates were recorded at time and location of sampling with a Magellan unit. Coordinates were plotted using TopoUSA 5.0 computer program. 
Figure 7. Topographical map indicating the GPS coordinates and sampling site locations in Breckinridge County, Kentucky.

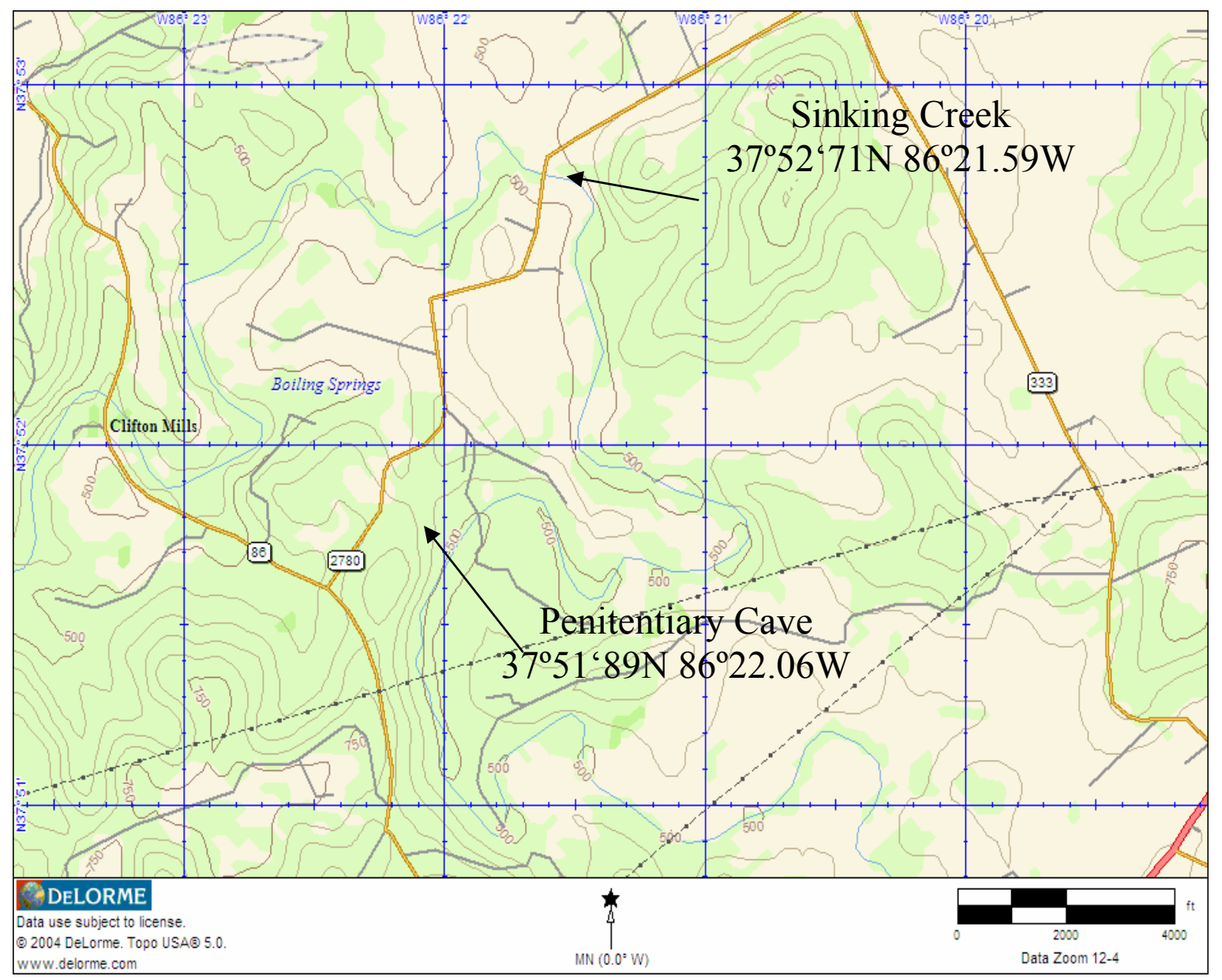

Legend: GPS coordinates were recorded at the time and location of sampling. Coordinates were plotted using the TopoUSA 5.0 computer program. 
Figure 8: Rimstone sampling site in Penitentiary Cave.

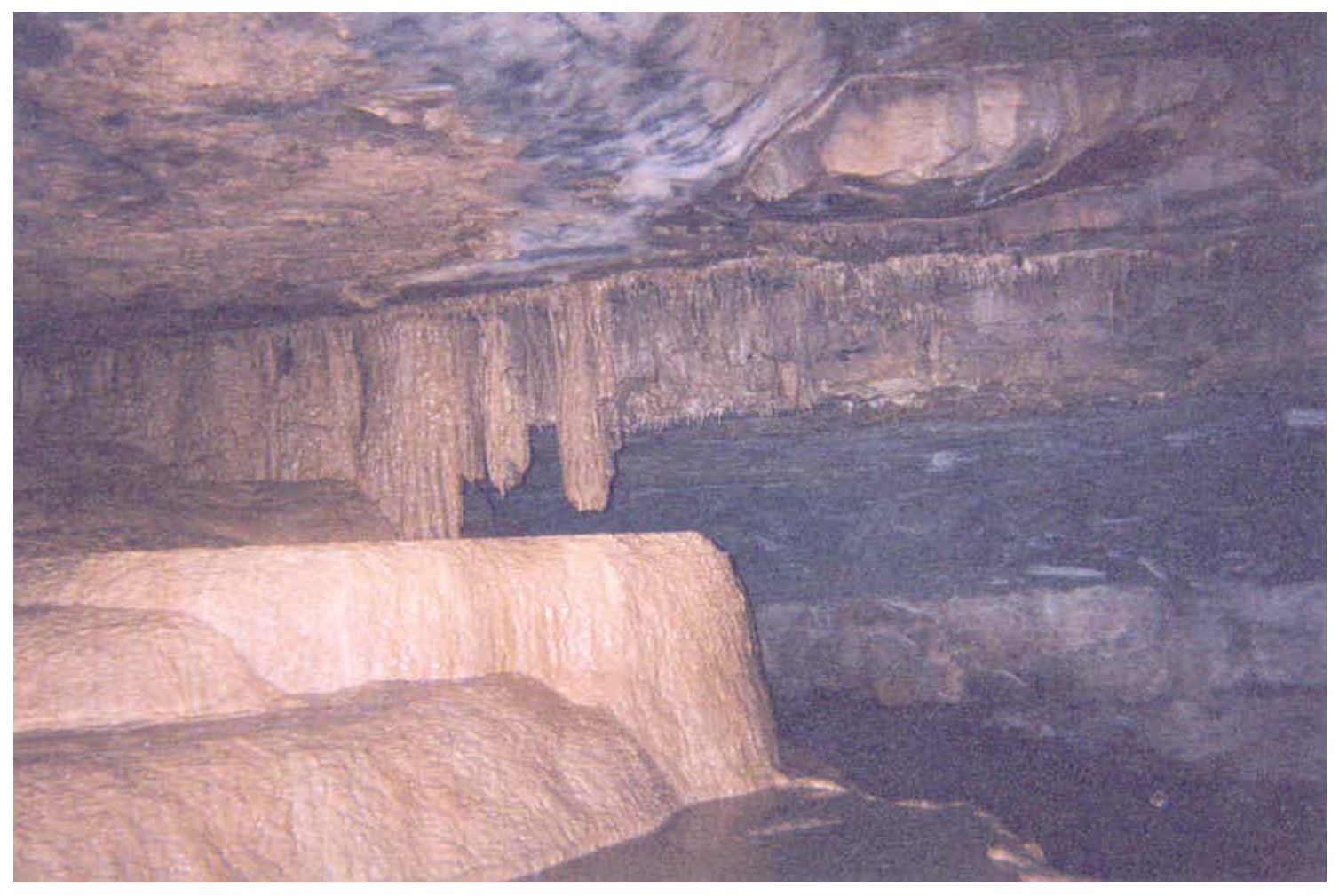

Legend: This photo shows the large rimstone dam and formations in Penitentiary Cave. Samples were taken from the pools formed in the steps. 
Figure 9: Sampling site in Belt Cave.

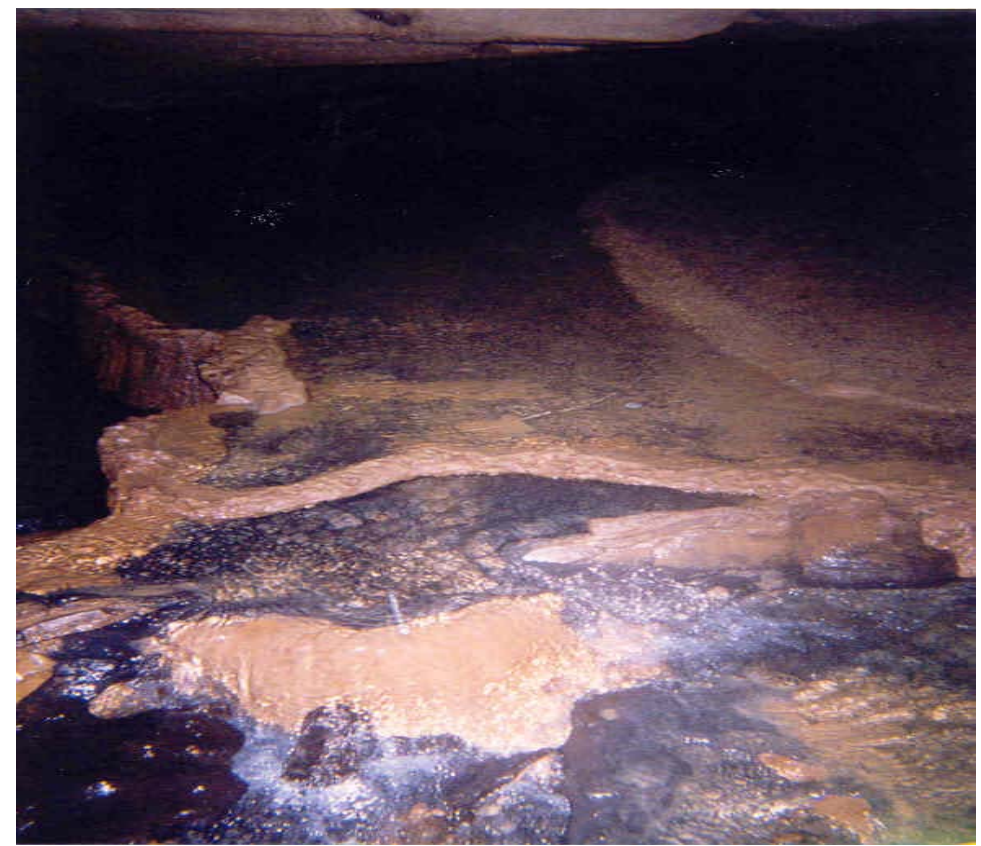

Legend: Measuring the temperature in a small waterfall in an underground stream of Belt Cave, Hardin County, Kentucky. Samples were collected in the pool above the thermometer pictured here. 
Figure 10. Sampling pool in Penitentiary Cave.

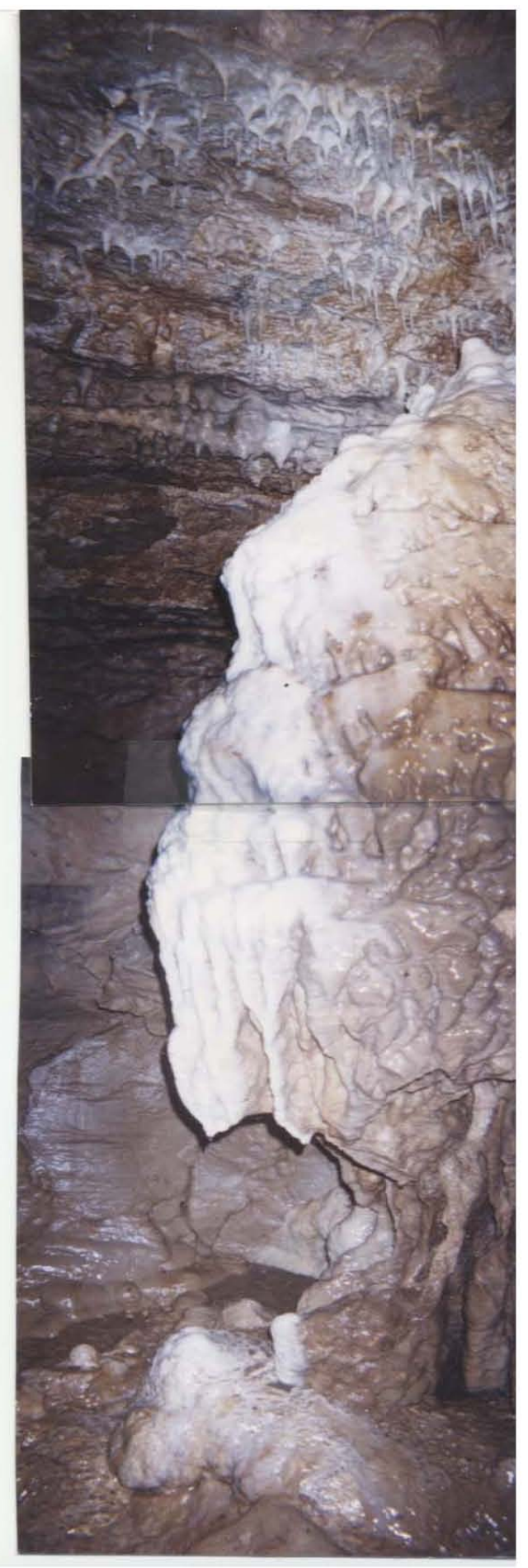

Legend: This photo shows a sampling location in Penitentiary Cave. The soda straw formations on the cave ceiling are formed from dripping water. 
Figure 2: Cross-sectional representation of the elevations and distances between sampling sites at Belt Cave and Funks Run approximated from a topographical map (USGS, Howe Valley Quadrangle)

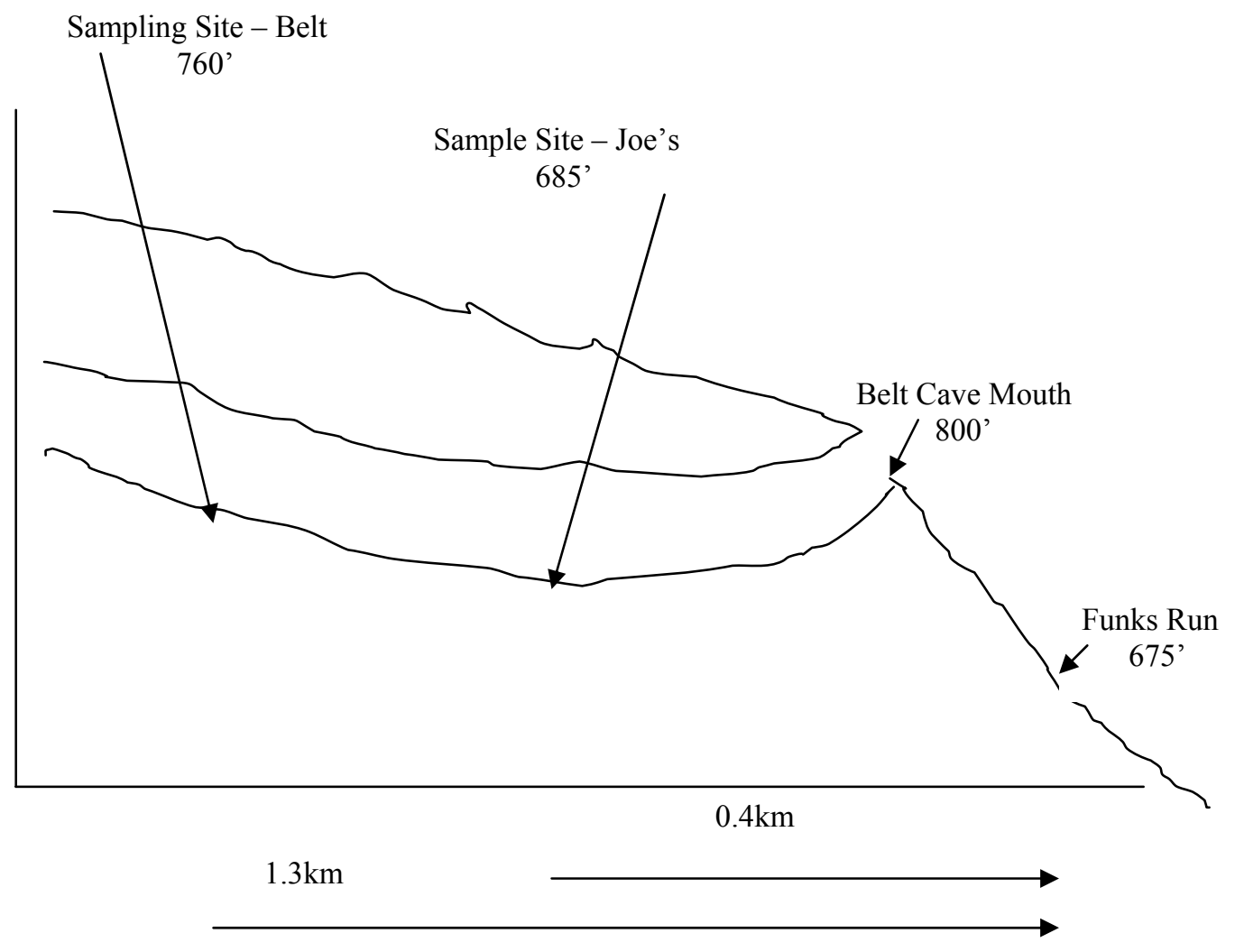

Legend: This illustration shows the approximate elevations and locations of sampling sites at Belt Cave and Funks Run as estimated from the Howe Valley Quadrangle USGS topographical Map. 
Figure 3. Elevations and locations of sampling sites at Penitentiary Cave and Sinking Creek approximated from a topographical map (USGS, Garfield Quadrangel).

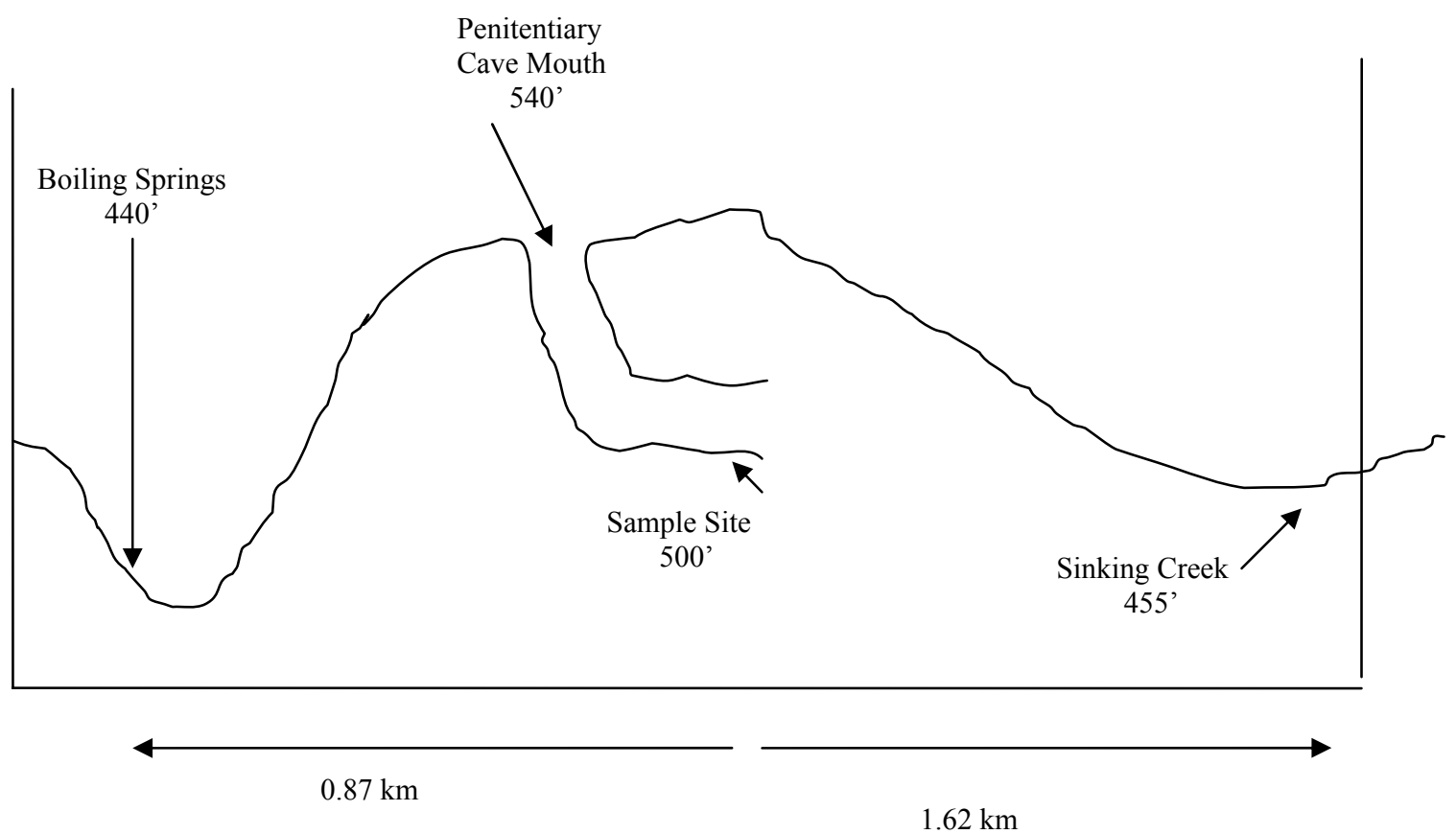

Legend: This is a cross-sectional illustration of the approximate elevations and distance between sampling sites at Penitentiary Cave and Sinking Creek as estimated from the Garfield Quadrangle USGS topographical Map. 
Figure 1. Number of Acres in Farmland in Kentucky by county, 1997

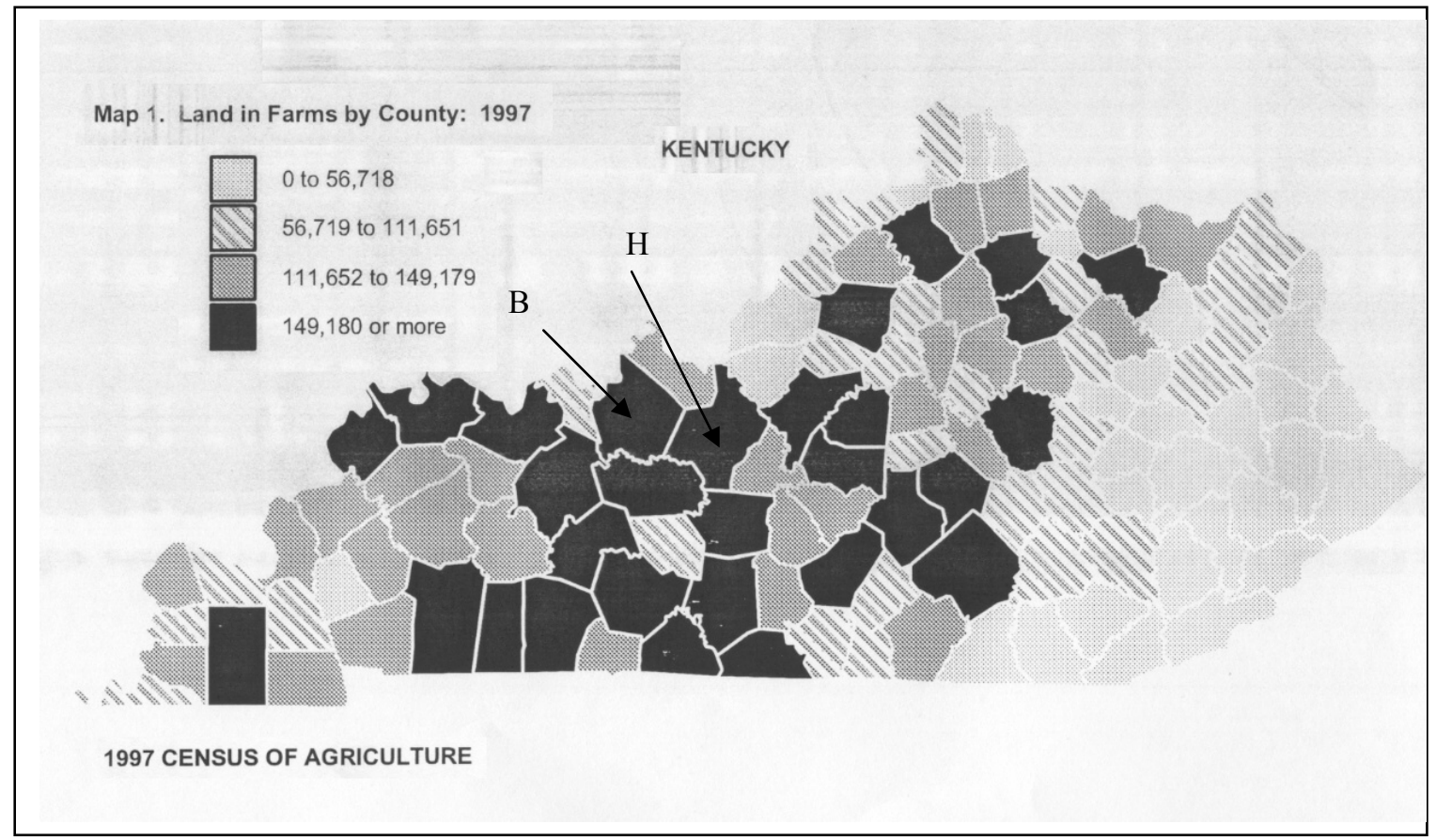

Legend: This map shows the number of acres in farmland in Kentucky by county in 1997 (United States Department of Agriculture 1997). Breckinridge County is indicated by B and Hardin County $=\mathrm{H}$. Penitentiary Cave and Sinking Creek sampling sites were located in Breckinridge County while Belt Cave and Funks Run are in Hardin County. 


\section{SAMPLING}

Samples for DNA extraction, cell counts, particle size, and calcium analysis were collected from sediments. Other parameters such as water chemistries and physical characteristics were measured from associated waters. Within the caves, samples were taken where water properties, such as temperature, indicated no recent contact with surface waters.

A core sediment sampler was used to collect approximately 500 gram samples from two sites within each cave and at the two surface sites. Core samples were transferred to sterile Whirl-Pak bags, labeled with date and sample location, and placed upon ice until arrival in the lab. Samples were aliquotted for particle size and calcium analyses. The remainder was frozen at $-20^{\circ} \mathrm{C}$ until DNA was extracted. Sediment samples for cell counts were aseptically collected using wooden spatulas and transferred to sterile $2.0 \mathrm{ml}$ tubes. The tubes contained a final concentration of $1 \%$ glutaraldehyde (GTA) solution (0.20 gm NaH $\mathrm{gO}_{4}, 0.61$ gm Na $\mathrm{HPO}_{4}, 30 \mathrm{~mL}$ distilled $\mathrm{H}_{2} \mathrm{O}, 20 \mathrm{~mL}$ 25\% glutaraldehyde) to preserve cell morphology until cells were counted by direct microscopy. These samples were also placed on ice until arrival in the laboratory and stored at $4^{\circ} \mathrm{C}$ until further processed.

\section{PHYSICAL AND CHEMICAL MEASUREMENTS}

Field measurements of $\mathrm{pH}$, temperature $(\mathrm{T})$, conductivity and dissolved oxygen were taken at most sites. Conductivity and $\mathrm{pH}$ were measured using a YSI meter. Standards of $\mathrm{pH} 4.0$ and 7.0 were used to calibrate for $\mathrm{pH}$ before measurements were made in the field. The conductivity probe was standardized using a $0.01 \mathrm{M} \mathrm{KCl}$ solution. The probe was rinsed three times with the sample before a reading was taken, and all readings were 
standardized to $25^{\circ} \mathrm{C}$. Temperature was recorded from a calibrated thermometer.

Dissolved oxygen was determined in mg/L using a LaMotte Model EDO kit (LaMotte Company, Chestertown, MD) utilizing the azide modification of the Winkler titration method and a direct reading titrator in the final titration step. This is an EPA approved procedure. To avoid contamination during collection the sample bottle was thoroughly rinsed with sample water before sample collection. The sample bottle was capped and submerged before removing the cap to allow the bottle to fill. Air bubbles were removed by tapping the sides of the submerged bottle and the cap was replaced while the bottle was still submerged. Once a satisfactory sample was collected, the sample was immediately "fixed" by the addition of manganous sulfate Solution (36\%) and alkaline potassium iodide azide (60-70\% potassium hydroxide and $1 \%$ sodium azide). The sample was capped and mixed gently by inverting several times. The precipitate was allowed to settle below the shoulder of the bottle before the addition of one gram of sulfamic acid (100\%) and gentle mixing until the reagent and precipitate were dissolved. Multiple samples were collected, fixed, and carried back to the laboratory for testing. Titration was performed on $20 \mathrm{~mL}$ of "fixed" sample using sodium thiosulfate $(0.025 \mathrm{~N})$. Before titration, 8 drops of $0.5 \%$ soluble starch was added to the sample as a color indicator. While gently shaking, sodium thiosulfate was added one drop at a time to the sample. Titration continued until the blue color just disappeared and the solution appeared clear. Results were converted to $\mathrm{mg} / \mathrm{L}$. Percent saturation of dissolved oxygen was determined using the titrated dissolved oxygen and temperature results and a nomograph (Figure 11).

One liter samples were collected in Nalgene bottles for laboratory analyses of nitrates+nitrites, ammonia, total nitrogen, soluble reactive phosphorus (SRP), total 
Figure 11. Nomograph used for determination of percent saturation of dissolved oxygen.
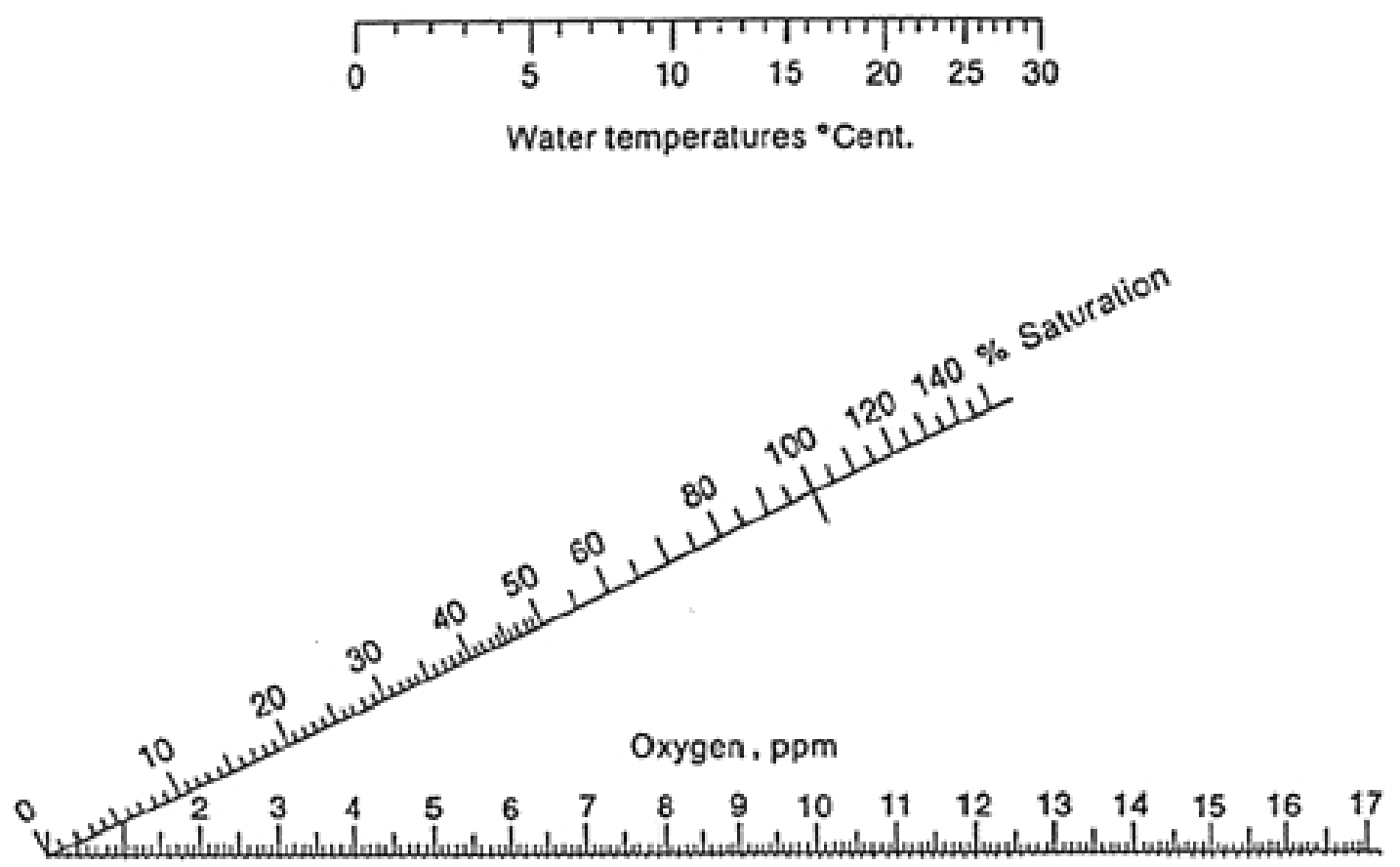

Legend: This is a reproduction of the nomograph used for determination of percent saturation dissolved oxygen in water samples (www.nrri.nmn.edu). 
phosphorus, silica, dissolved organic carbon (DOC), and chloride. The analyses were performed in the Environmental Analysis Laboratory at the University of Louisville, according to Standard Methods for the Examination of Water and Wastewater (Greenburg 1998).

Water column samples for chlorophyll $a$ and phaeophyton were collected one time from a number of sites within Belt Cave in September 1999. Samples were analyzed by the flourometric method as described in Standard Methods, Section 10200H (Greenburg 1998).

Calcium analyses were performed on sediment samples from each of the collection sites $(n=6)$ in the Environmental Analysis Laboratory at the University of Louisville. Collection of the samples is described above. Sediments were prepared by digestion according to Standard Methods Section 3030F and calcium was measured by flame atomic absorption using a nitrous oxide acetylene flame as described in Standard Methods, Section 3111E (Greenberg 1998).

Calcium was also measured on sediments and DNA extracts from the same samples. Extractions were performed by the same BIO101 method and calcium was measured using basic flame photometry by atomic absorption. A nitric acid digestion was necessary before the measurement of calcium in the sediments (Rich Schultz, Environmental Analyses Laboratory, University of Louisville). For comparison, results were standardized to $\mathrm{mg} \mathrm{Ca/gm} \mathrm{sediment.}$

Laser technology was utilized to perform particle size analyses on the same six sediment samples submitted for calcium determination. A Coulter LS Particle Size Analyzer LS230 in the Research \& Development Laboratory at Whip-Mix Corp., 
Louisville, KY was used to measure the particles, determine the distribution of particle sizes and categorize the results in increments from 0.040 to $2,000 \mu \mathrm{m}$.

\section{B. CHARACTERIZATION OF MICROORGANISMS}

\section{PLATE COUNTS}

Samples for plate counts were collected on two separate occasions. On January 8, 2000, six Petri plates were left at each of five sampling sites: Two plates each of R2A agar (Difco), $\mathrm{H}_{2} \mathrm{O}$ Agar (1L tap water with 2\% agarose), and Soil Agar (prepared by boiling approximately 1000 grams of sediment in distilled water and adding $2 \%$ agarose to the decanted liquid portion after settling). All three types of media were autoclaved before pouring and plates were incubated overnight at $37^{\circ} \mathrm{C}$ to check for contamination. One plate of each media type was inoculated with a $100 \mu 1$ sample from the watersediment interface and dispersed with a disposable plate spreader. These plates were left along with one uninoculated control plate of each type to incubate in the sampling environment (Total $n=30)$. Plates were collected and transported on ice in separate sterile bags to the laboratory after 16 days. After recording the observed colonies, the entire plate surface containing all colonies formed was swabbed to $2.0 \mathrm{ml}$ tubes containing sterile water for storage at $-20^{\circ} \mathrm{C}$.

In November and December of 2002, plate counts were performed for five of the six sampling sites. Only one sample from Belt Cave was plated as the second site was inaccessible due to high water. Both $10 \mu 1$ and $100 \mu 1$ volumes of water from the sediment water interface were spread evenly over R2A plates, placed on ice, and incubated upon return to the laboratory at $4^{\circ} \mathrm{C}$ along with an uninoculated control plate. 
Colonies were observed, photographed, and counted after 17 days. Cultured microbes were collected in unison as above and stored at $-20^{\circ} \mathrm{C}$ in sterile water until further analysis. These samples, containing a culturable portion of the bacterial community, were used for the ARDRA analysis described below.

\section{DIRECT CELL COUNTS}

Samples for cell count analysis were collected aseptically using disposable wooden spatulas as described above and preserved with buffered GTA at a final concentration of $1 \%$. Samples were refrigerated at $8^{\circ} \mathrm{C}$ until filtering and staining was performed. All reagents were made at time of actual sample counts. Counts were carried out using epifluorescent microscopy procedures (Kepner and Pratt 1993, Yu et al. 1995) and DAPI stain.

Filtration and staining, as well as bacterial cell counts were carried out in a darkened room. All samples and reagents were allowed to equilibrate to room temperature before filtration and staining was performed. One gram of sample was aseptically weighed and transferred to $9.0 \mathrm{~mL}$ of $0.01 \mathrm{M} \mathrm{NaPPi}$ buffer. Samples were allowed to sit for 15-30 minutes before being shaken vigorously by hand to dislodge and disperse cells from sediment particles. After assembling the filter apparatus (Figure 12), the backing filter was pre-wet with one drop of sterile diluent $\mathrm{H}_{2} \mathrm{O}$, placed on the filter base, and topped with a pre-wetted $10 \mathrm{~mm}$ diameter black membrane filter (pore size $0.2 \mu \mathrm{m}$ ) keeping the shiny side of the filter face-up. One hundred microliters of the buffered sample were diluted in $0.9 \mathrm{ml}$ (900 microliters) of DAPI stain in the filter funnel. The diluted sample $(1 / 100)$ and fluorochrome (final concentration $0.5 \mu \mathrm{g} / \mathrm{ml})$ were allowed contact for 20 minutes before the cell suspension was drawn through the filter using a $60 \mathrm{cc}$ syringe. 
Figure 12. Apparatus for sample filtration for direct cell counts by fluorescent microscopy.

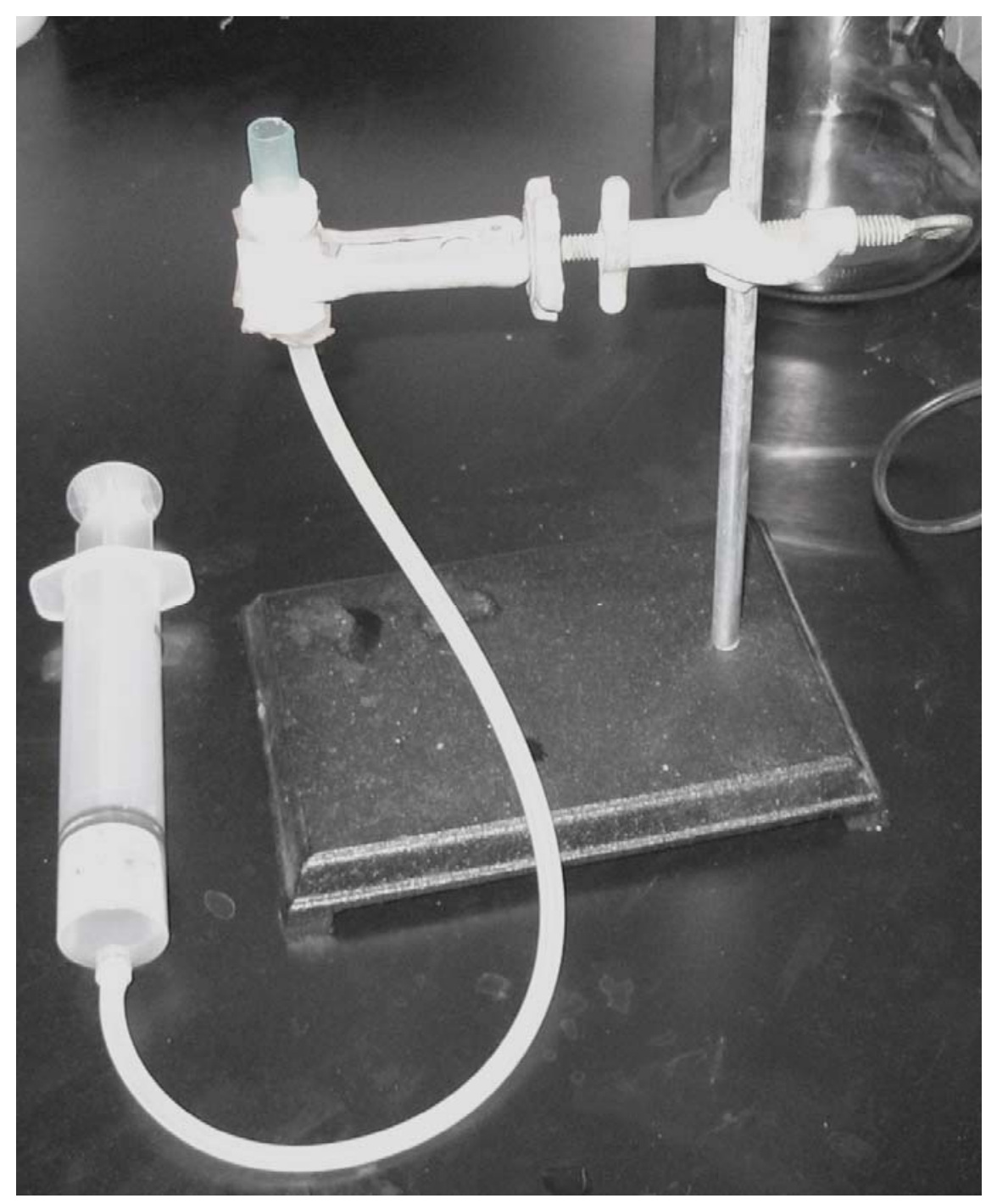

Legend: This photo shows the apparatus used to filter samples for direct cell counts by fluorescent microscopy. Sample was pulled through the column and filter ( 0.2 micron) by the use of a $60 \mathrm{cc}$ syringe. 
The membrane filter was rinsed with approximately $1.0 \mathrm{ml}$ diluent water to remove the excess stain and enhance image contrast. The membrane filter was removed with forceps and prepared for immediate counting.

All slides were counted in a darkened room on the day of staining and filtration, as recommended. A drop of Cargill low fluorescence immersion oil was placed on a labeled, acetone-cleaned, glass microscope slide. The filter was placed, sample side up on top of the oil and another drop of immersion oil was placed on top of the black, membrane filter. The filter was topped with a clean coverslip and pressed gently to spread the oil and remove any air bubbles from beneath the coverslip. Cells were counted at 1000X using a Olympus BH-2 Research light microscope and filter sets appropriate for visualization of DAPI stain. A minimum of 200 cells per filter were counted falling within a minimum of 5 fields of view (0.0064 sq mm each). The effective area of the membrane filter $(10 \mathrm{~mm}$ diameter $)$ and not the entire filter area $(13 \mathrm{~mm})$ was utilized to determine bacterial density in the original sample.

\section{DNA EXTRACTION}

Two different methods of DNA extraction were used. Both methods included a combination of mechanical and chemical means for lysis and extraction. A modified version of The Fast DNA SPIN Kit for Soil (Bio 101) was used to extract DNA from the cultured portion of the community. One hundred microliters of the cultured colonies collectively homogenized in $1 \mathrm{ml}$ of sterile water were used. This procedure consisted of three steps: lysis in a phosphate/SDS buffer, homogenization, and purification/elution. Five hundred milligrams of sample were aseptically weighed or $100 \mu 1$ of homogenized plate culture was pipetted to $978 \mu$ l of kit supplied buffer and added to the provided 
Multimix Tissue Matrix Tube containing a variety of silica and ceramic beads. The method was modified by the addition of 0.050 gm of acid-washed polyvinyl polypyrrolidone (PVPP) (Holben et al. 1988) to the lysis buffer and a 5.5M guanidine isothiocyanate (GTC) wash before the salt-ethanol washes (SEWS) in the SPINTM filter. In addition, matrix tubes were secured to the pad of a Thermolyne Type 16700 Mixer and vortexed for 12-15 minutes instead of the recommended FASTPREP instrument. In all steps, the longer recommended spin times were used. The resulting DNA was eluted with $50 \mu 1$ of kit supplied DNase/pyrogen free water (DES), or PCR grade water (Sigma), after allowing the water to interact with the DNA/silica matrix on the SPINTM filter for 5 minutes.

Another method used for extraction of total genomic DNA was modified from the method of Zhou et al. (1996). Ten grams of soil were used for extraction instead of five as described by Zhou. The other modification included vortexing samples with a variety of silica/glass beads (Kuske et al. 1998) after each addition of SDS. Depending upon the sample to be extracted, 10 grams of soil (wet weight) or $1000 \mu$ l of culture growth homogenized in sterile water was aseptically transferred to $50 \mathrm{ml}$ autoclaved, round bottomed polyethylene tubes containing a variety of silica beads and $25 \mathrm{ml}$ of extraction buffer with $1 \%$ CTAB. $200 \mu 1$ of Proteinase K $(1 \mathrm{mg} / \mathrm{ml})$ was added to each tube and samples were vortexed for 1 minute before incubation at $37^{\circ} \mathrm{C}$ on a rotational shaker at $225 \mathrm{rpm}$ for 30 minutes. After initial incubation, $3.0 \mathrm{ml}$ of $20 \% \mathrm{SDS}$ was added to each tube and samples were placed in a $65^{\circ} \mathrm{C}$ waterbath for 2 hours with gentle end-over-end mixing every 15 minutes. At the end of the 2 hours, each sample was vortexed for 10 minutes and centrifuged at room temperature at $6,000 \mathrm{~g}$ X 10 minutes. The supernatant was removed to a sterile, $500 \mathrm{ml}$ centrifuge bottle. This process was repeated two more 
times using the remaining pellet and the resulting supernatants were pooled before the addition of an equal volume of chloroform:isoamyl alcohol (24:1). The aqueous phase was recovered by centrifugation at $6,000 \mathrm{~g}$ X 10 minutes at room temperature and the DNA was precipitated with a 0.6 volume of isopropanol at room temperature for either 1 hour or overnight. After collecting the DNA by centrifuation at $16,000 \mathrm{~g} \mathrm{X} 20$ minutes, the DNA was washed with 5.5M GTC followed by several washes of ice cold $70 \%$ ethanol. After drying, the DNA was resuspended with $70^{\circ} \mathrm{C}$ sterile PCR grade water to a final volume of $500 \mu 1$.

The presence and size of the DNA extracts from both methods were verified by electrophoresis in $40 \mathrm{mM}$ Tris-acetate-1 mM EDTA (TAE) buffer (Ausubel 1989). The TAE Buffer was made at a 10X concentration and diluted to $1 \mathrm{X}$ for making agarose gels and filling the electrophoresis chamber. Thirteen microliters of extract plus $2 \mu 1$ of tracking dye were loaded on a $1 \%$ agarose gel spiked with $0.5 \mu \mathrm{g} / \mathrm{ml}$ of ethidium bromide at $5 \mathrm{~V} / \mathrm{cm}$ for 30 minutes. Eight microliters of a Hi-Lo DNA Marker (Minnesota Molecular) with band sizes ranging from 50-10,000 basepairs was loaded with each gel. Nucleic acids were visualized using ultraviolet light at a wavelength of 302nm and photographed on Polaroid Professional B\&W 667 film.

Extraction efficiency was determined using direct cell counts and absorbance readings of the DNA extract. Theoretical yield of DNA was calculated using E. coli genome as a standard in the following formula:

$\left[4.2 \times 10^{6} \mathrm{bp} \mathrm{DNA} /\left(0.965 \times 10^{9} \mathrm{bp} \mathrm{DNA} / \mathrm{pg}\right)\right] \mathrm{X}$ number of cells/gm $=$ theoretical $\mathrm{pg} \mathrm{DNA} / \mathrm{gm}$ of sediment.

Efficiency of the extraction was given as actual yield/theoretical yield.

Concentration and purity of samples were measured using absorbance values 
according to Current Protocols in Molecular Biology (Ausubel 1989). An aliquot from each sample was diluted in 1X TNE Buffer (1.0 mM EDTA, $10 \mathrm{mM}$ Tris, $0.2 \mathrm{M} \mathrm{NaCl}$, $\mathrm{pH}$ 7.4) and transferred to quartz cuvettes for absorbance readings. Because of a need to conserve sample, Tm cuvettes were used, which allow sample volumes as small as $300 \mu 1$ to be accurately measured while still maintaining a $1 \mathrm{~cm}$ pathlength. Measurements were made on a Beckman-Coulter DU640 spectrophotometer. After blanking the spectrophotometer with the buffer, the absorbance of each sample was measured at 230, 260, 280, and $325 \mathrm{~nm}$ wavelengths and recorded. Yields of DNA were calculated using the absorbance reading at $260 \mathrm{~nm}$ (Ausubel 1994). The remaining wavelengths were used to determine the purity of the samples. To check accuracy, controls of salmon testes DNA (Sigma Chemical, St. Louis) or E. coli DNA (Sigma Chemical, St. Louis) were measured in addition to the samples. Concentration of DNA in the samples was calculated using the following formula:

Concentration $(\mathrm{mg} / \mathrm{ml})=\mathrm{A}_{260} / 50($ for double-stranded DNA $)$.

The purity of samples was measured using various absorbance ratios:

A260/A280 Ratio should be 1.8-1.9

A260/A230 Ratio should be 1.9-2.0

\section{POLYMERASE CHAIN REACTION}

As part of the preparations for setting up a PCR, all racks, tips, tubes, and pipettors were wiped with $70 \%$ ethanol and placed under UV illumination in a biological hood for 30 minutes. Either fifty or one hundred microliter polymerase chain reactions were set in PE Biosystems Gene Amp Reaction tubes (Perkin-Elmer). For all amplification reactions, before the addition of polymerase and template DNA, all other components of the PCR were filtered in the following manner. Five hundred microliters of sterile water 
was added to two separate Microcon YM-100 (Millipore) filter units ( $\mathrm{NCO}=125 \mathrm{ds})$ and centrifuged in a Sorval Microspin 12-S at 10,000 rpm for 10 minutes. After discarding the filtrate, another $500 \mu 1$ of water was added to one filter and the PCR cocktail mixture was added to the second filter unit. These were centrifuged again for 10 minutes as in the first step of the procedure. These filtrations were performed to remove any nucleic acids present in the reagents before the addition of template DNA. After the second spin, the master mix was transferred to the twice rinsed filter with a clean catch tube and centrifuged approximately 8 minutes or until all master mix had passed through the filter. The polymerase was then added, mixed briefly, aliquotted into PCR tubes, and the template DNA was added to each tube.

All reactions, unless otherwise noted, contained: 1X PCR Buffer, $200 \mu \mathrm{M}$ each deoxynucleoside triphosphate (Sigma dNTP Mix), $1.5 \mu \mathrm{M} \mathrm{Mg}(\mathrm{OAc})_{2}$ or $1.5 \mu \mathrm{M} \mathrm{MgCl}$ (kit supplied, depending upon polymerase used), and $0.2 \mu \mathrm{M}$ each UniF and UniR (Giovanonni et al. 1990) primers (Genosys) or the primer pair EUB1 and EUB2 (Tani et al. 1998). Primer sequences and amplification targets are listed in Table 1. One unit of rTth polymerase (PE Applied Biosystems) or 2.0 units of Taq polymerase per $50 \mu 1$ was added after filtration of the master mix. Reactions were carried out in a MJ Research, Inc PTC-100 programmable thermal cycler. Parameters for the thermal cycler were: Step 1$94^{\circ} \mathrm{C}$ for $5 \mathrm{~min}$, Step $2-94^{\circ} \mathrm{C}$ for $1 \mathrm{~min}$, Step $3-42^{\circ} \mathrm{C}$ for $1 \mathrm{~min}$, Step $4-72^{\circ} \mathrm{C}$ for $90 \mathrm{sec}$, Step 5-34 times to Step 2, Step 6-72 ${ }^{\circ} \mathrm{C}$ for $7 \mathrm{~min}$. 
Table 1. Primer sequences of primer pairs used for PCR amplification in this study.

\begin{tabular}{|c|c|c|c|}
\hline Primer & Primer sequence $\left(5^{\prime}-3^{\prime}\right)$ & Specificity & 16S Target \\
\hline UniF & 5'TGCCAGCAGCCGCGGTA3' & Universal & $516-532$ \\
\hline UniR & 5'GACGGGCGGTGTGTACAA3' & Universal & $1391-1406$ \\
\hline Eub 1 & 5'GGCTTAACACATGCAAGTCG3' & Domain & \\
\hline Eub 2 & 5'GGACTACCAGGGTATCTAATCCTG3' & Domain & \\
\hline
\end{tabular}

Legend: Listed are the sequences and target sites (based on E. coli numbering) of primers used for PCR amplification in this study. The specific target for Eub1 and Eub2 primer pair is not given here as it was not published with the designed primer sequence (Tani et al. 1998). 


\section{INHIBITION EXPERIMENTS}

Six sets of experiments were performed to evaluate the inhibition of PCR from these cave sediment samples: 1) Cave samples were seeded with E. coli cells before extraction or E. coli and cave DNA were mixed after extraction. 2) Cave DNA template was diluted. 3) Reactions containing E. coli template were spiked with varying concentrations of cave DNA extract. 4) Reactions were spiked with serial dilutions of $\mathrm{CaCl}_{2}$ using both $\mathrm{rTth}$ and Taq polymerases. 5) Reactions were spiked with serial dilutions of $\mathrm{CaCO}_{3}$ using both $\mathrm{rTth}$ and Taq polymerases. 6) Extraction methods were compared using E. coli and cave samples.

To ascertain if the inhibitory compounds were preventing cell lysis or if they were being extracted with the DNA, an experiment was performed spiking cave samples with E. coli cells before extraction or mixing cave extracted DNA with E. coli DNA after extraction. E. coli cells were added to the lysis buffer along with the 0.500 grams of Penitentiary cave sediment. A sample of 0.500 grams of cave sediment alone and a sample of E.coli cells alone were also extracted. DNA was extracted according to the modified BIO 101 protocol. After extraction, $10 \mu 1$ of E. coli extract and $10 \mu 1$ of cave sediment extract were mixed. Four PCR reactions were set: E. coli DNA alone, cave sediment DNA alone, E.coli and cave sediment DNA extracted together, and E. coli and cave sediment mixed after extraction. Each reaction contained 1XPCR Buffer (Sigma) $200 \mu \mathrm{M}$ of each dNTP, $0.2 \mu \mathrm{M}$ of each primer (UniF and UniR), $1.5 \mathrm{mM} \mathrm{MgCl} 2,1 \mathrm{U}$ of Taq polymerase, and $1 \mu 1$ of template. The same results were obtained using DNA from Belt Cave and a $0.4 \mu \mathrm{M}$ concentration of Eub1 and Eub 2 primers (Tani et al. 1998).

For performing the template dilution experiment, dilutions of the Belt 2 sample were

made in pre-filtered water at concentrations of $1 / 2,10^{-1}, 10^{-3}, 10^{-5}, 10^{-6}, 10^{-7}, 10^{-8}, 10^{-9}$, and 
$10^{-10}$. Five microliters of each dilution were used as template. In addition, the undiluted sample was used as a template. E. coli DNA was run as a positive control. After obtaining these results, the experiment was repeated using dilutions only to $10^{-6}$.

To determine the point at which the addition of cave sediment extract might be inhibitory to the amplification of $E$. coli template, reactions containing approximately 20ng of E. coli DNA were spiked with $5 \mu$ l of increasingly dilute solutions of the same Belt 2 extract from the template dilution experiment above. Dilutions of cave extract were between $1 / 2$ and $10^{-8}$.

Calcium chloride as an inhibitor of the PCR was assessed by spiking reactions with varying concentrations of $\mathrm{CaCl}_{2}$ and using bacterial DNA from cave cultures, cave sediment DNA, or E. coli DNA as the template. Final concentrations of $\mathrm{CaCl}_{2}$ ranging from $1.0 \mathrm{M}$ to down to $0.04 \mathrm{mM}$ were evaluated. The calcium chloride solution was unfiltered and dilutions were added individually to each tube before the addition of polymerase. Each group of samples for amplification was set with both $r T$ th and Taq polymerases.

Calcium carbonate as an inhibitor was also investigated. A saturated solution of $\mathrm{CaCO}_{3}$ was used to make dilutions at $1 / 2,1 / 4,1 / 10,1 / 20,1 / 40$, and $1 / 100$. Five microliters of each dilution in addition to the undiluted solution were added to a fifty microliter reaction containing $1 \mu 1$ of either SDS extracted cave sediment DNA or E. coli DNA as template. One unit of rTth polymerase was used for each reaction. The calcium carbonate was added after filtration of the reaction components.

E. coli and Belt 2 samples were extracted with three different methods utilizing the BIO101 protocol: 1) without any additional treatments, 2) with the addition of $50 \mathrm{mg}$ acid-washed PVPP in the lysis buffer, and 3) with a 5.5M GTC rinse in addition to the 
added PVPP.

A comparison of the SDS method of extraction and the BIO101 kit extraction was made using equal concentrations of $E$. coli extracts and cave sediment extracts from each extraction method for PCR amplification. All PCR-products were analyzed by electrophoresis in 1XTAE Buffer at $5 \mathrm{~V} / \mathrm{cm}$ along with a size standard (Minnesota Molecular) for comparison. Amplification was considered successful by the presence of an 891 bp fragment.

\section{ARDRA}

Following optimization using E. coli and one cave sample, restriction endonucleases were used to digest the $0.8 \mathrm{~kb}$ fragments of $16 \mathrm{~S}$ rDNA amplified from the total community samples and those from a cultured portion of the communities. One or more of the following enzymes were used for the restriction analyses: RsaI (NE BioLabs 10 units $/ \mu \mathrm{l})$, HhaI (USB 12 units/ $\mu \mathrm{l}$ ), and BanI (NE BioLabs 20 units/ $\mu 1)$.

Sequence recognitions for the enzymes used are listed below:

RsaI GT/AC

BanI G/GYRCC where $\mathrm{R}=\mathrm{A}$ or $\mathrm{G}$ and $\mathrm{Y}=\mathrm{C}$ or $\mathrm{T}$ HhaI GCG/C

Three microliters of BIO101 extracted DNA from communities culturable at $4^{\circ} \mathrm{C}$ on R2A plates were used for a single $(50 \mu 1)$ PCR. Successful amplification was checked by gel electrophoresis and after verification of proper sized amplicons, these samples were used directly without further clean-up for restriction analyses.

Each reaction for plate cultured communities contained $2 \mu 1$ 10X Buffer (NE BioLabs Buffer 4), $2 \mu 1$ of BSA (final concentration of $100 \mu \mathrm{g} / \mathrm{ml}$ ), $8 \mu 1$ of template, $8 \mu 1$ PCR grade water, and $0.5 \mu 1$ of each enzyme. Samples were digested at $37^{\circ} \mathrm{C}$ for 2 hours and the 
entire $20 \mu 1$ of reaction was electrophoresed for 2 hours at $5 \mathrm{~V} / \mathrm{cm}$ on a $3 \%$ agarose gel (FMC SeaPlaque) spiked with $0.5 \mu \mathrm{g} / \mathrm{ml}$ ethidium bromide and visualized by UV illumination (VWR Transilluminator) at $302 \mathrm{~nm}$. Results were photographed using a $\mathrm{P}$ Polaroid camera (Fotodyne, Inc.) and Polaroid Professional B\&W 667 film.

Total community DNA was diluted $1 / 100$ or $1 / 1000$ for PCR. Amplified total community rDNA samples were digested in $40 \mu \mathrm{l}$ reactions containing $32 \mu 1$ of template directly from PCR, $4 \mu 1$ 10X Buffer (NE BioLabs Buffer 4), $4 \mu$ 1 BSA (final concentration $100 \mu \mathrm{g} / \mathrm{ml}$ ), and $1.0 \mu \mathrm{l}$ of each restriction enzyme (10-12 units). These samples were digested for 2 hours at $37^{\circ} \mathrm{C}$ and electrophoresed for three hours on a $4 \%$ agarose gel (FMC SeaPlaque) containing ethidium bromide before observation by UV illumination. Digestion of the total community $16 \mathrm{~S}$ amplicons was repeated using samples which were concentrated and purified by centrifugal filtration.

A $3 \mu 1$ volume of $E$. coli $16 \mathrm{~S}$ amplicon was digested with the plate culture samples and $5 \mu 1$ of $E$. coli $16 \mathrm{~S}$ was digested with the total community DNA as a control. The restriction sites for the amplified region of E. coli $16 \mathrm{~S}$ were obtained from the ribosomal sequence database and fragment lengths were checked for accuracy of the digestion enzymes. Similarity of communities was compared using Sorensen's coefficient of similarity (Sorensen 1948). The formula is $\mathrm{Cs}=2 \mathrm{j} /(\mathrm{a}+\mathrm{b})$. In this equation, $\mathrm{a}=$ number of bands in Sample A. The number of bands in Sample B is given as $b$, and $\mathrm{j}$ is the number of bands common to Sample A and Sample B. Cs=the coefficient of similarity.

\section{REASSOCIATION}

All reassociation experiments were carried out in standard saline citrate (SSC) buffer using a thermal controlled spectrophotometer (Beckman-Coulter DU 640). Buffer was 
diluted from a 20X stock solution (3.0 M NaCl, 0.3 M sodium citrate, $\mathrm{pH}$ 7.0). While samples contained varying amounts of DNA extract, all dilutions were made to $300 \mu 1$ volumes and transferred to quartz cuvettes. Cuvettes were stoppered to prevent evaporation.

Samples for total genomic reassociation were diluted 1/10 in 5XSSC Buffer and sheared by sonication on ice to approximately $1 \mathrm{~kb}$. Ten microliters of each sample was used to verify average fragment size on $1 \%$ agarose by gel electrophoresis. Three hundred microliters of the remaining sheared total genomic DNA were pipetted to quartz cuvettes for reassociation experiments. After baseline readings at $25^{\circ} \mathrm{C}$, the temperature was raised to $100^{\circ} \mathrm{C}$ and absorbance readings at $260 \mathrm{~nm}$ were allowed to stabilize. The temperature controller was disabled and absorbance readings were recorded every 0.2 minutes for the first 10 minutes. After the initial 10 minutes, absorbance readings at $260 \mathrm{~nm}$ were recorded every 15 minutes for the remainder of the experiment. Samples were standardized from $100 \%$ to $0 \%$ single stranded and plotted against time.

For reassociation of the total community $16 \mathrm{~S}$ rDNA amplicons, extracts from the total community (10 gm SDS extraction) were diluted at $1 / 100$ or $1 / 1000$ based upon results from inhibition experiments for PCR amplification. A negative control containing no template was run with each set of amplification reactions. Five replicates $(100 \mu 1$ reactions) of each sediment extract ( $6 \mu \mathrm{l} /$ reaction) were amplified for use in reassociation experiments. Ribosomal DNA from E. coli was also amplified and processed in the same manner as the $16 \mathrm{~S}$ rDNA amplified from the sediments. Eight microliters of pooled PCR product was electrophoresed on $1 \%$ agarose to verify appropriate size band.

Six replicates $(50 \mu 1$ reactions $)$ of each plate culture extracted by the BIO101 method were amplified ( $3 \mu \mathrm{l} /$ reaction) without dilution. All replicates were pooled prior to 
verification of proper size product by electrophoresis on $1 \%$ agarose.

Following amplification, 16S rDNA fragments were prepared for reassociation experiments. Amplicons remaining after verification of appropriate sized bands were cleaned and concentrated using centrifugal filtration (Micropure-EZ and Microcon YM100). Two hundred and fifty microliters of each pooled PCR mixture was loaded into a Micropure-EZ enzyme remover filter (Millipore) pre-rinsed with PCR grade water and centrifuged (Sorvall Instruments Microspin-12S) according to package insert for two minutes to remove the polymerase. This was repeated with the remaining $250 \mu 1$ of pooled sample using the same filter. The Micropure-EZ filter containing the polymerase was discarded. After a double rinse with sterile PCR grade water according to manufacturer's instructions, the entire $500 \mu \mathrm{l}$ of PCR mixture was loaded into the Microcon YM-100 filter unit and centrifuged at 500xg for 5 minutes. Another 500 microliters of PCR grade water was added to each filter and centrifuged at 500xg for an additional 5 minutes to remove remaining salts and dNTPs. The rinse step was repeated before filters were inverted in clean catch tubes and centrifuged at 1000xg for 1-2 minutes to elute the concentrated PCR products. Three microliters of purified 16S amplicons were used to check again for appropriate bands on $1 \%$ agarose before dilution in standard saline citrate (SSC) buffer for reassociation experiments. Both cultured and total community amplicons were diluted in 0.1XSSC Buffer for reassociation experiments.

After baseline readings at $25^{\circ} \mathrm{C}$, sample temperature was raised to $95^{\circ} \mathrm{C}$. Samples were allowed to stabilize and then the temperature controller was disabled, creating a sudden drop in temperature. Readings were taken beginning immediately after heat was discontinued $(\mathrm{T}=0)$ and every 6 seconds for at least 10 minutes. Experiments were 
discontinued at the end of a programmed time. Files were transferred to Excel for graphical analysis. Samples were normalized from 100 to $0 \%$ single stranded (ss) according to baseline and $100^{\circ} \mathrm{C}$ absorbance readings at $260 \mathrm{~nm}$. The concentration of single stranded DNA (ssDNA) beginning with 100\% was plotted against time (in seconds) to determine reassociation rates. E. coli $16 \mathrm{~S}$ rDNA amplified from a commercial source (Escherichia coli strain B, Sigma Chemical) in the same manner as study samples was used as a standard of complexity. 


\section{RESULTS}

\section{A. PHYSICAL AND CHEMICAL PROPERTIES}

Chlorophyll $a$ concentrations were $6.682 \mu \mathrm{g} / \mathrm{L}$ in surface waters while in cave waters concentrations were much less ranging from $0.002-0.184 \mu \mathrm{g} / \mathrm{L}$. The presence of chlorophyll $a$ in subsurface waters indicates a recent influx of surface waters containing organisms which possess photosynthetic abilities. Even the highest concentrations of chlorophyll found in a cave water sample were well below those found in surface water samples. Similarly, phaeophyton was greatly reduced in cave waters. Surface samples contained $6.184 \mu \mathrm{g} / \mathrm{L}$ compared to only $0.036-0.988 \mu \mathrm{g} / / \mathrm{L}$ in subsurface samples. Phaeophyton is a product formed from the degradation of chlorophyll $a$ which is quickly broken down upon cell death. Although more stable than chlorophyll $a$, phaeophyton should be degraded and not found in high levels in waters which do not have contact with the surface. When considered together, phaeophyton contributed a higher percentage of the total compounds in cave samples, whereas chlorophyll $a$ was higher than phaeophyton in surface samples (Figure 13).

While temperature readings from surface waters ranged from 4 to $31^{\circ} \mathrm{C}$ during the sampling period, temperatures of the cave waters fluctuated only one degree around $12^{\circ} \mathrm{C}$ (Figure 13). Since water temperature influences dissolved oxygen concentrations and because temperature differences were observed between surface and subsurface sites, dissolved oxygen (DO) was converted to percent saturation for comparison. Surface sites averaged $112 \%$ saturated while cave sites were on average $87 \%$ saturated with 
Figure 13. Chlorophyll and phaeophyton levels of surface and cave waters.

\section{CHLOROPHYLL and PHAEOPHYTON \\ SURFACE V. BELT CAVE}

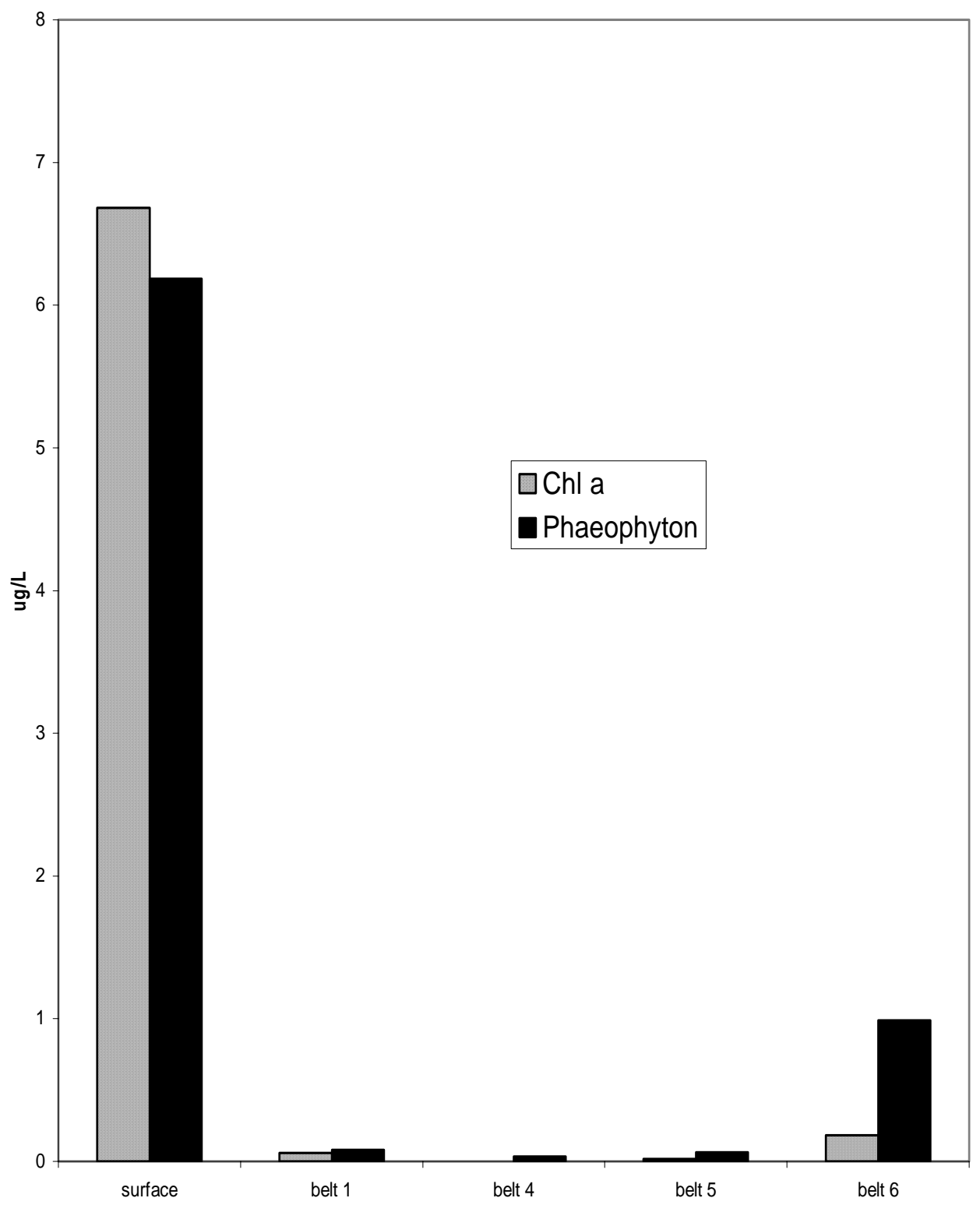

Legend: A comparison of the levels of chlorophyll $a$ and phaeophyton in Belt Cave and nearby surface waters in Hardin County, Kentucky, September 2000 as measured by fluorometry. Levels of both compounds were significantly greater in surface waters than in all cave sites sampled. 
Figure 14. Temperature fluctuations in cave and surface waters of Breckinridge and Hardin counties, Kentucky.

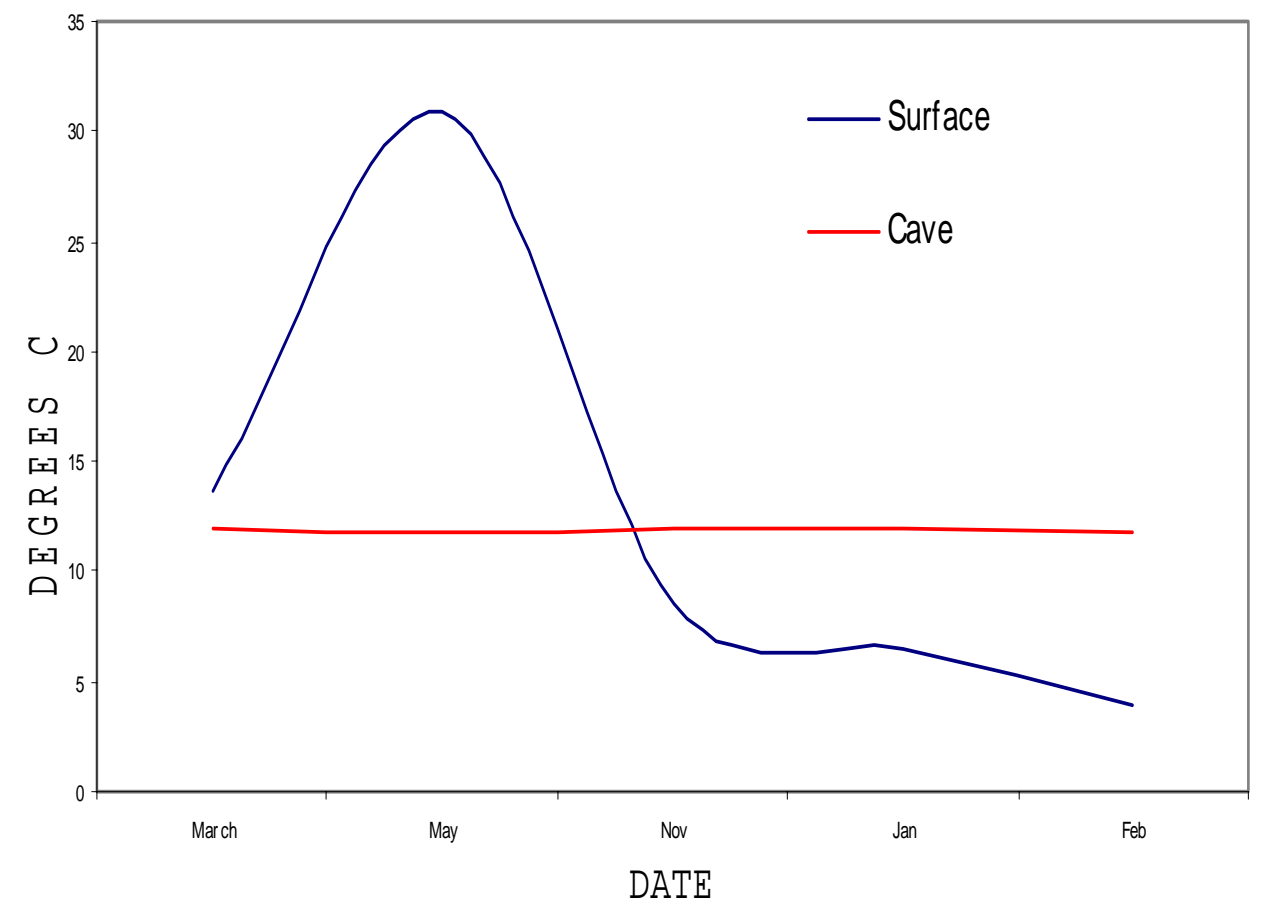

Legend: Temperature fluctuations of selected cave and surface waters in Breckinridge and Hardin Counties, Kentucky. Data were pooled from three years of sample collection between 1998-2001. (Surface $n=15$, Cave $n=27$ ) 
dissolved oxygen (results not shown).

Conductivity (Figure 15) differed significantly between surface and cave sites using a one-factor ANOVA $(\mathrm{p}=.009)$ with unequal sample size and there was a significant

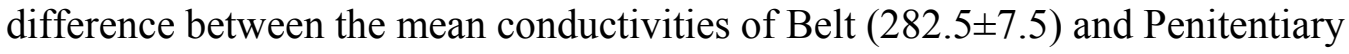
$(477.8 \pm 38.5)$ cave sites using Tukey's test $(\mathrm{p}<.05) . \quad \mathrm{pH}$ values also differed between the two cave sites (Figure 16). $\mathrm{pH}$ was consistent within sites and ranged from 7.1-8.5 at all sites sampled.

Table 2 ranks the sample locations for most of the water chemistry results. A sample for water chemistries was not included from the surface site of Funks Run. All samples were listed from lowest to highest concentrations of each parameter for comparison. The sample location Pen 1 ranked either highest or lowest for each of the tests conducted.

Table 3 summarizes the data collected for selected physical and chemical characteristics of five of the six sample locations. Chloride concentrations in all cave sites were much lower than those taken from surface sites (Figure 17). Silica ranged from 5.55 to $9.19 \mathrm{mg} / \mathrm{L}$ with no trend between sites (Figure 18). While dissolved organic carbon (DOC) levels in Penitentiary Cave were nearly the same as those in the surface site sampled (Sinking Creek), sites in Belt Cave contained only slightly more than one half of those values (Figure 19). Total nitrogen and nitrates/nitrites in Penitentiary Cave were lower than both surface and Belt Cave (Figure 20). Similarly, soluble reactive phosphorus (SRP) in Penitentiary Cave was less than one half the value of the lowest reading from Belt Cave or surface samples (Figure 21). In summary, Penitentiary Cave was lower in both total and fractionated nitrogen and phosphorus (SRP). However, dissolved organic carbon (DOC) was nearly twice as high as levels in Belt Cave and equivalent to levels found at the surface site. 
Figure 15. Graph of conductivity in cave and surface waters.

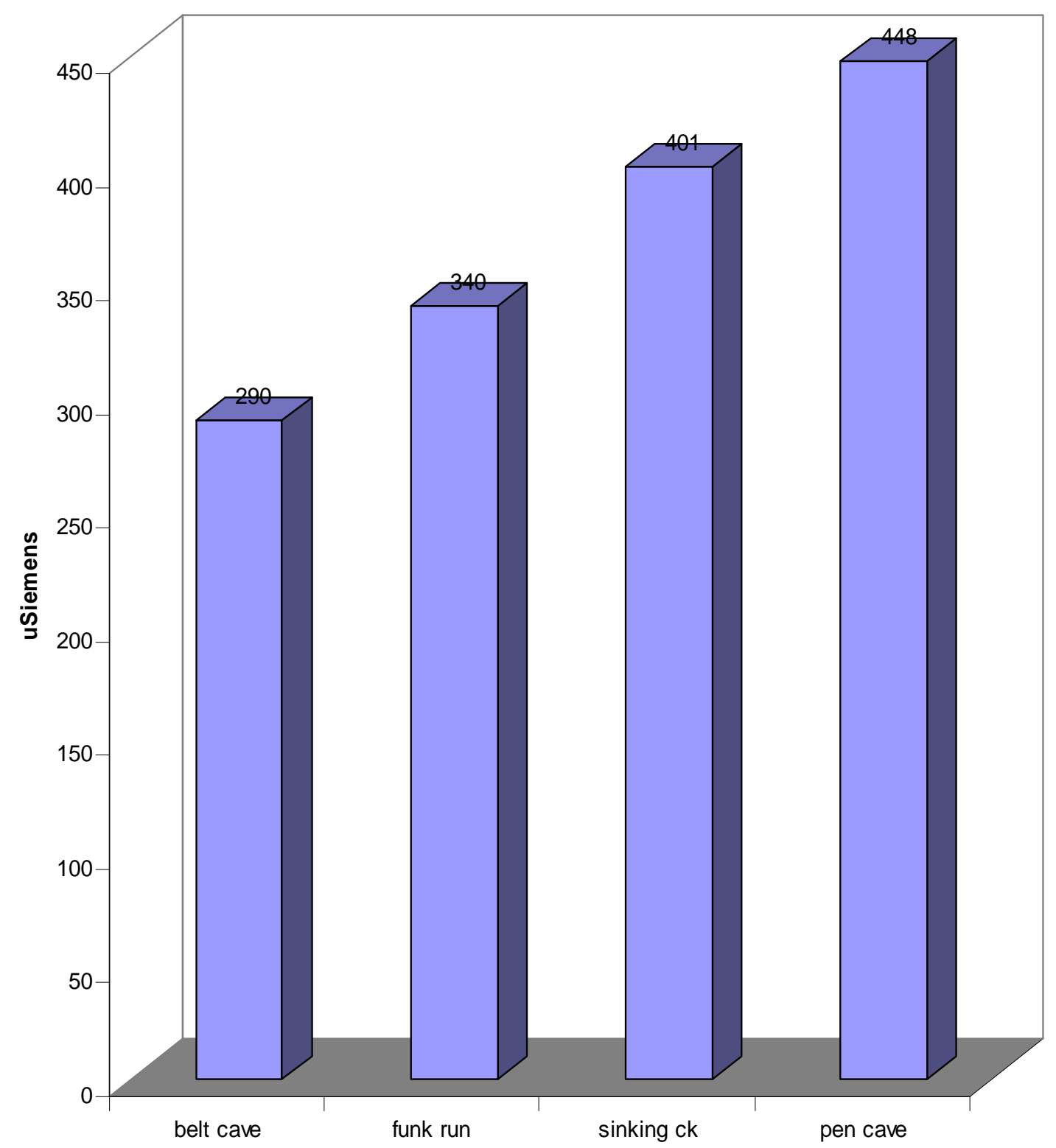

Legend: This chart indicates conductivity measured in surface and cave waters of Breckinridge and Hardin Counties, Kentucky over a period from 1998-2001. 
Figure 16. $\mathrm{pH}$ of surface and cave waters.

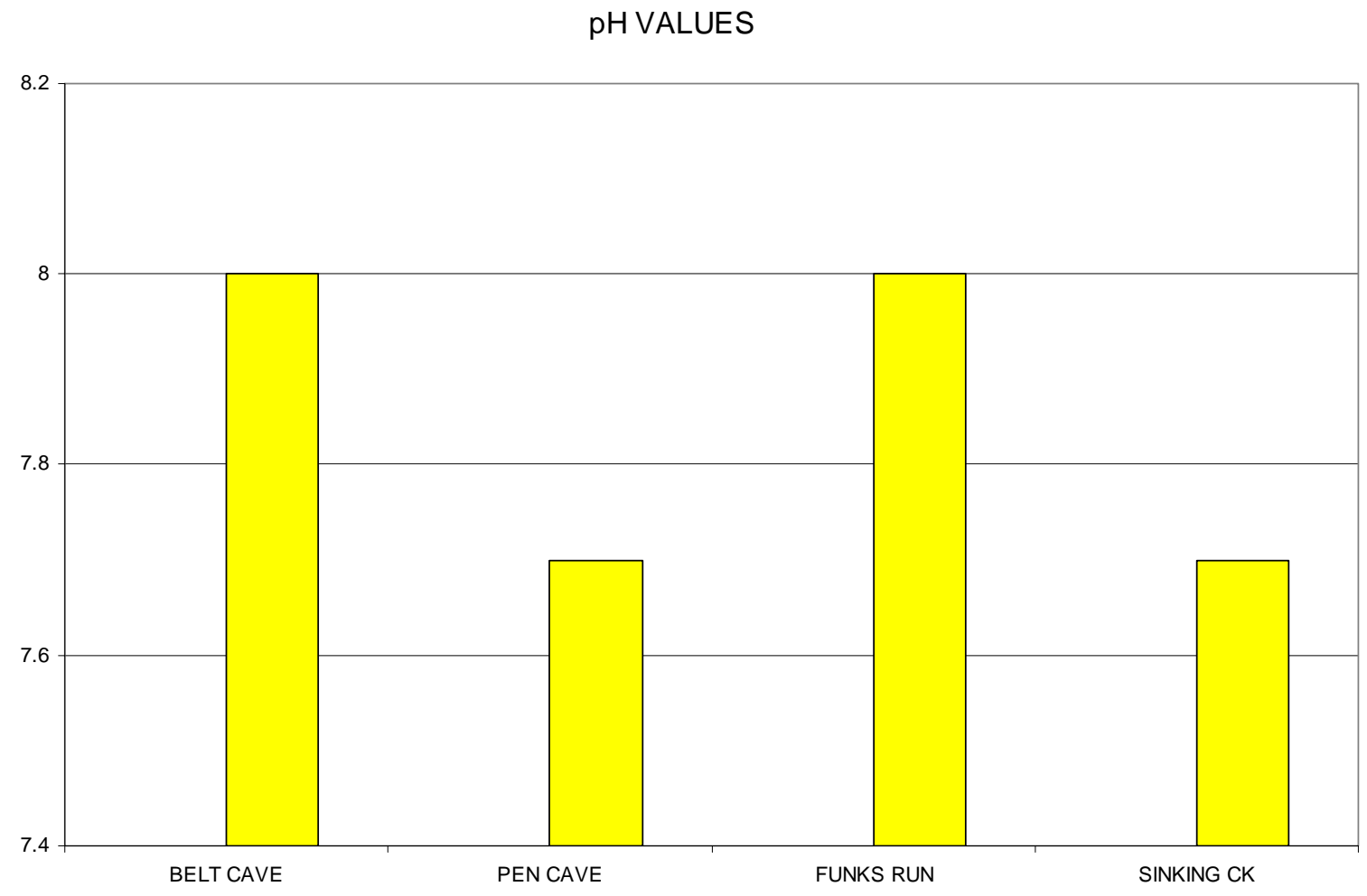

Legend: These are the average $\mathrm{pH}$ values of surface and cave waters sampled in Breckinridge and Hardin Counties, Kentucky for the period from 1998-2000. The values of cave and adjacent surface sites are equal. However, there is a difference between sites when grouped by area rather than cave versus surface. 
Table 2. Ranking of study sites for selected physical and chemical properties.

lowest
\begin{tabular}{|l|c|c|c|c|c|}
\hline Conductivity & B1 & B2 & S & P2 & P1 \\
\hline Nitrogen-T & P1 & P2 & S & B2 & B1 \\
\hline NO2+NO3 & P1 & P2 & S & B1 & B2 \\
\hline SRP & P1 & P2 & S & B2 & B1 \\
\hline TP & & P2 & B2 & S & B1 \\
\hline Silica & B1 & S & P2 & B2 & P1 \\
\hline DOC & B1 & B2 & P2 & S & P1 \\
\hline Chloride & P1 & P2 & B1 & B2 & S \\
\hline
\end{tabular}

Legend: All sample sites were ranked for each of the listed parameters. Rankings are from lowest to highest concentrations for each parameter. Note that the Penitentiary Cave site (P1) is always at the highest or lowest ranking for all parameters measured. $\mathrm{P} 1$ is not included in the total phosphorus (TP) ranking as a value was not reported for this sample. 
Table 3. Values for selected physical and chemical properties of surface and cave waters.

\begin{tabular}{|l|r|r|r|r|r|r|r|r|r|}
\hline SAMPLE ID & DATE & NO3+NO2 & \multicolumn{1}{|c|}{ TN } & \multicolumn{1}{c|}{ SRP } & TP & \multicolumn{1}{c|}{$\mathrm{Si}$} & $\mathrm{Cl}$ & $\mathrm{DOC}$ & $\mathrm{DO}$ \\
\hline & & $\mu \mathrm{g} / \mathrm{L}$ & $\mu \mathrm{g} / \mathrm{L}$ & $\mu \mathrm{g} / \mathrm{L}$ & $\mu \mathrm{g} / \mathrm{L}$ & $\mathrm{mg} / \mathrm{L}$ & $\mathrm{mg} / \mathrm{L}$ & $\mathrm{Mg} / \mathrm{L}$ & $\mathrm{Mg} / \mathrm{L}$ \\
\hline & & & & & & & & & \\
\hline SURFACE (SINK) & $1-8-00$ & 1732.3 & 2316 & 24.9 & 49.2 & 6.87 & 5.19 & 38.87 & 11.8 \\
\hline PEN 2 & $1-8-00$ & 918.4 & 1237 & 12.2 & 33.9 & 7.72 & 1.85 & 38.35 & 10.0 \\
\hline PEN 1 & $1-8-00$ & 328.3 & 1102 & 8.6 & $\mathrm{nr}$ & 9.19 & 1.75 & 40.53 & 10.4 \\
\hline BELT 1 & $1-8-00$ & 1746.7 & 2789 & 52.5 & 101.8 & 5.55 & 1.89 & 21.21 & 10.0 \\
\hline BELT 2 & $1-8-00$ & 2533.2 & 3282 & 26.9 & 39.8 & 8.25 & 3.57 & 28.67 & 11.4 \\
\hline
\end{tabular}

Legend: Water chemistries from surface and cave sites in Breckinridge and Hardin Counties, Kentucky, 2000. Analyses were performed in the Environmental Analysis Laboratory, University of Louisville. No value was reported for total phosphorus from the Pen 1 sample site. 
Figure 17. Chloride concentrations of surface and cave waters.

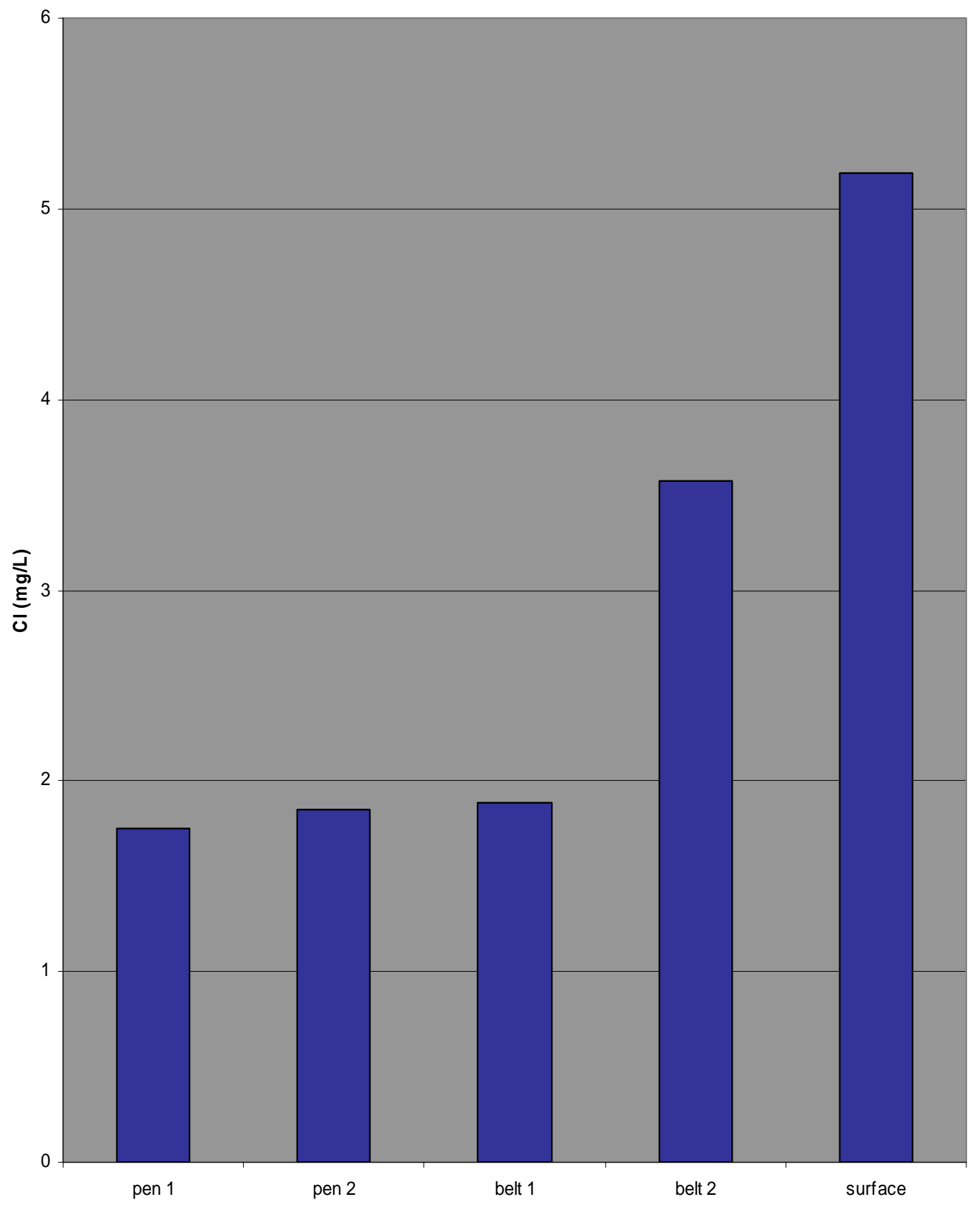

Legend: Chloride levels from Penitentiary and Belt Caves and from Sinking Creek, Breckinridge and Hardin Counties, Kentucky, January 2000. 
Figure 18. Silica concentrations of surface and cave waters.

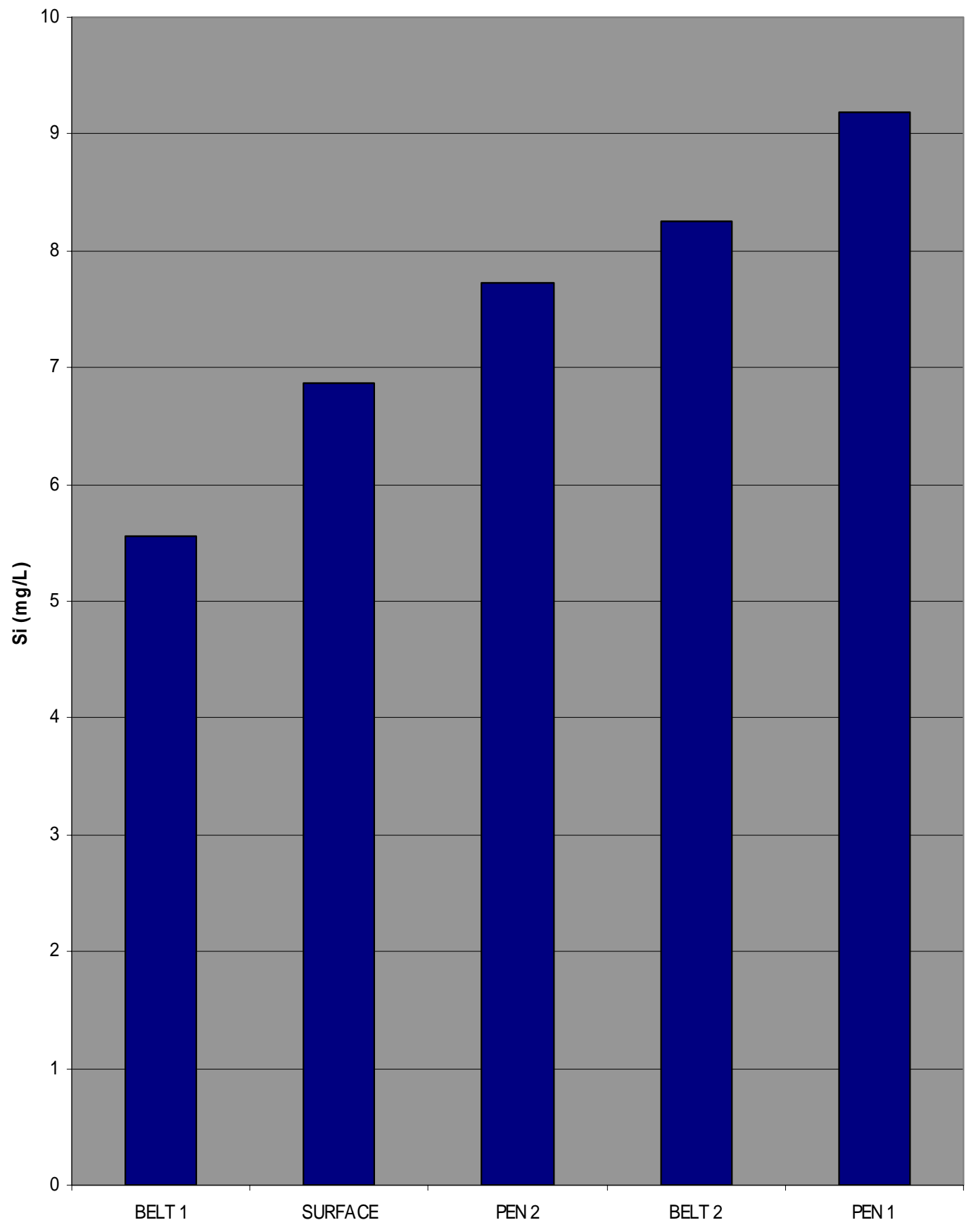

Legend: Silica concentrations in surface and cave waters of Breckinridge and Hardin Counties, Kentucky in January 2000. 
Figure 19. Dissolved organic carbon levels in surface and cave waters.

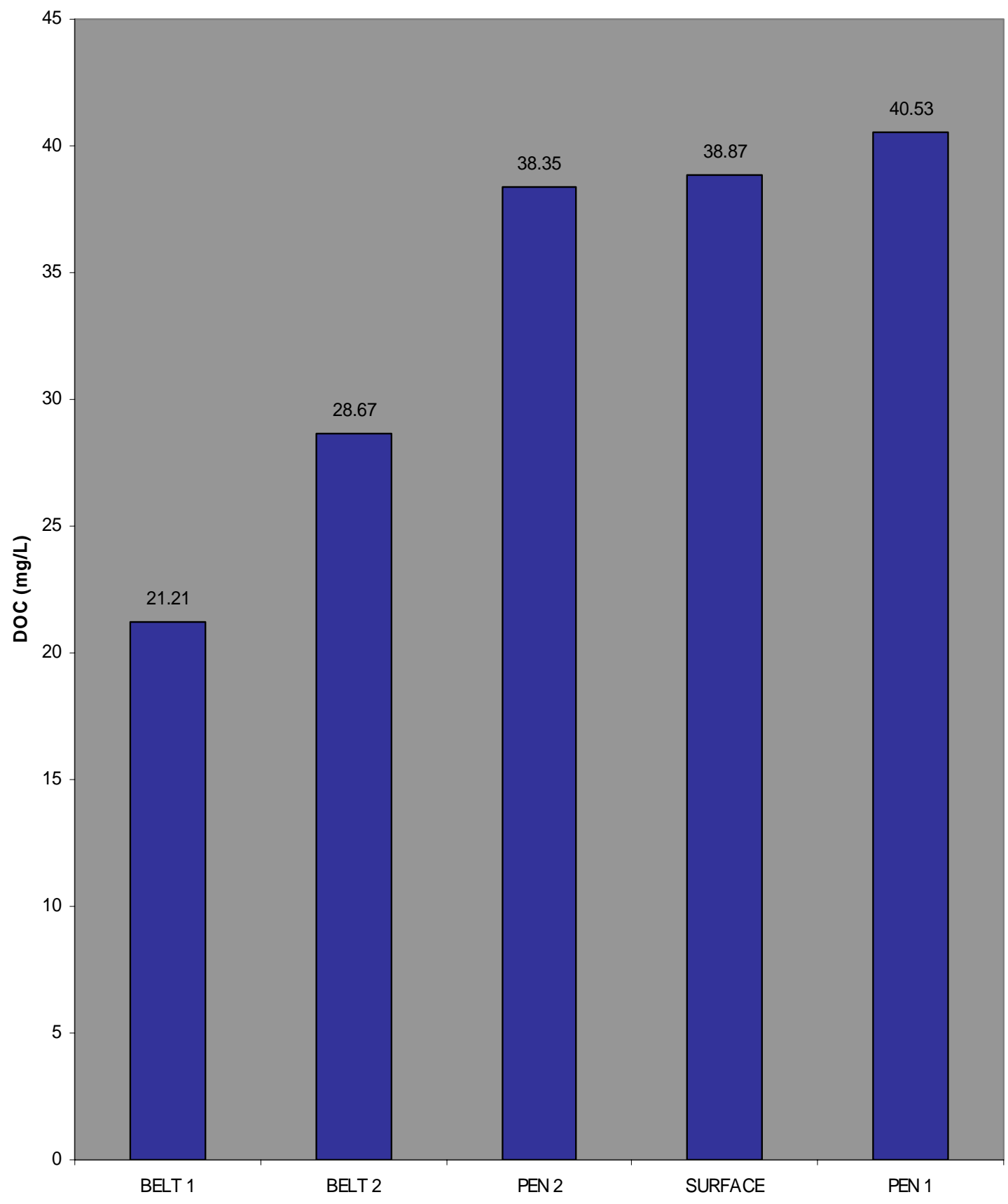

Legend: Dissolved organic carbon concentrations in Penitentiary and Belt Caves and Sinking Creek, Breckinridge and Hardin Counties, Kentucky, January 2000. 
Figure 20. Total and fractionated nitrogen levels in surface and cave waters.

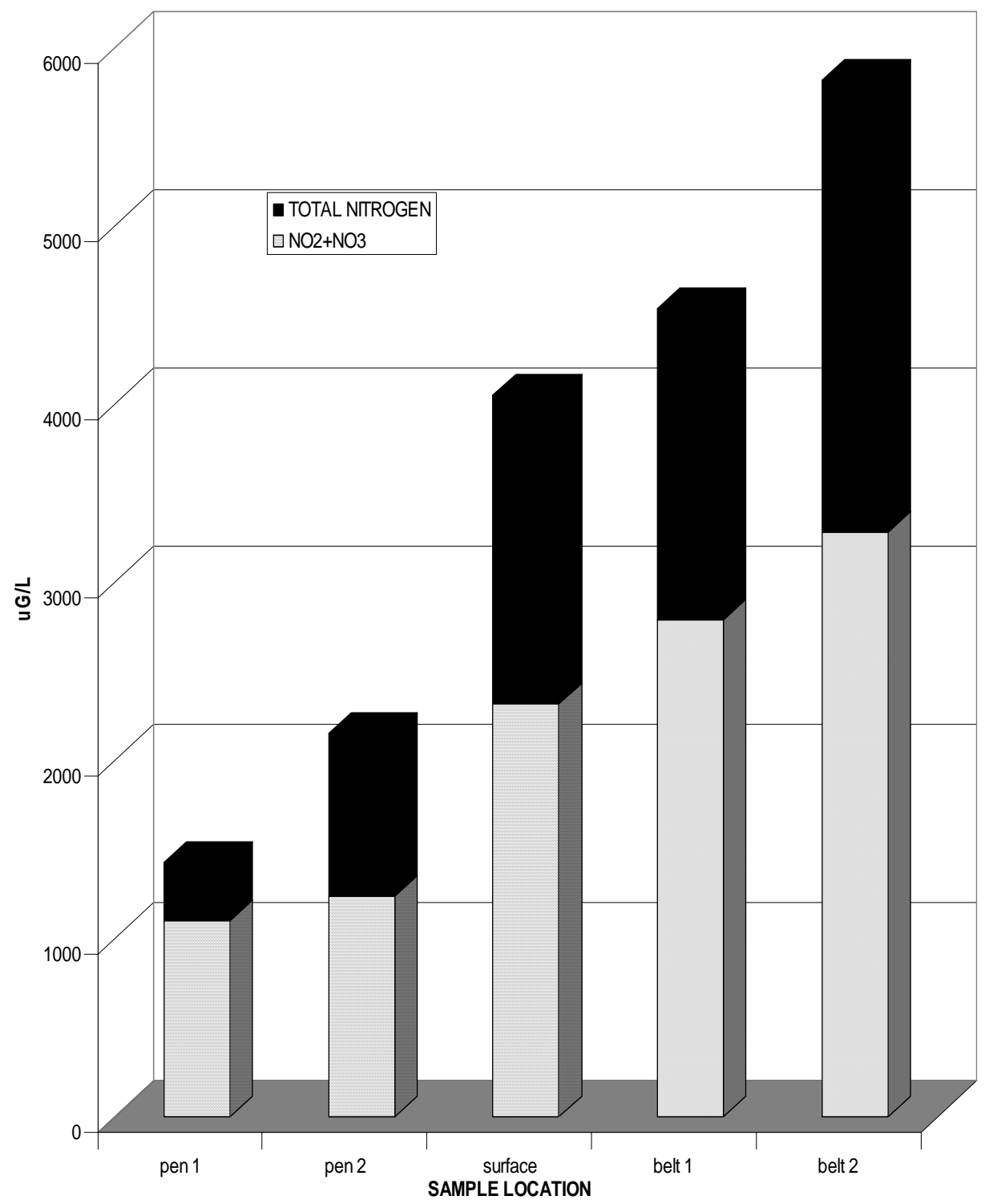

Legend: Total nitrogen levels in waters collected from Sinking Creek, Penitentiary Cave (Breckinridge County, Kentucky), and Belt Cave (Hardin County, Kentucky), in January 2000. Total nitrogen is indicated by the entire bar and the levels of nitrogen found as nitrates + nitrites by the dotted portion of the bar. 
Figure 21. Soluble reactive phosphorus levels in surface and cave waters.

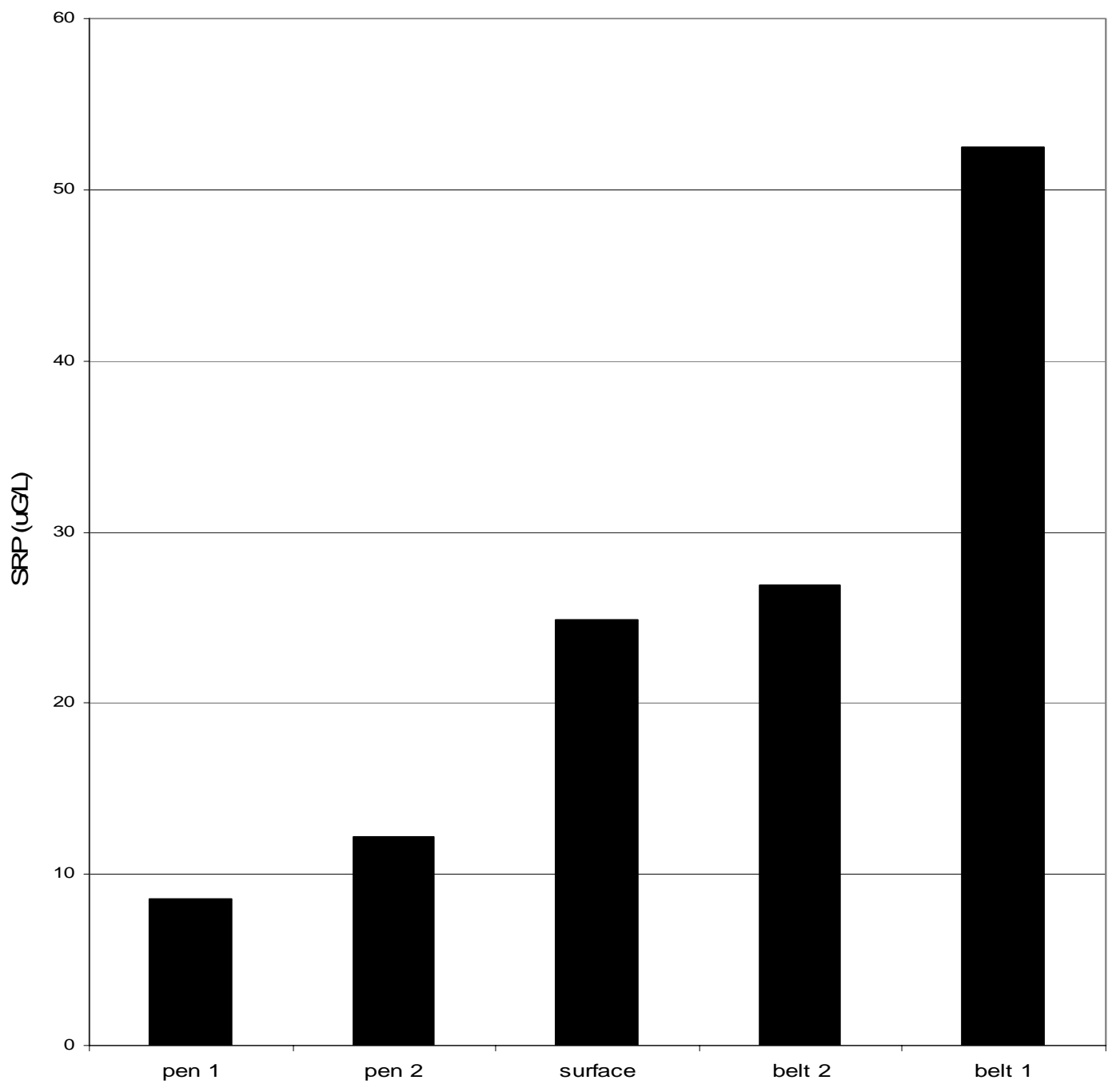

Legend: Soluble reactive phosphorus levels in surface and cave waters of Penitentiary Cave and Sinking Creek in Breckinridge County, Kentucky and in Belt Cave, Hardin County, Kentucky, January 2000. 
When sampling locations were grouped by cave $(n=5)$ or surface $(n=3)$, calcium levels in cave water column samples analyzed (Table 4) were lower than those in surface waters (Figure 22), but the difference was not significant ( t-test, unequal sample size, $\mathrm{p}=0.134)$. The two Belt Cave samples had the lowest values of calcium in water column samples taken from subterrranean samples.

The sediments collected varied between sites upon visual inspection of the samples (Figures 23 and 24). All sediments were analyzed by laser particle size analysis. Mean particle size and volume statistics were calculated on particles categorized between 0.040 and 2,000 $\mu \mathrm{m}$ (Figure 25). Sediment from Belt Cave (Belt 2) exhibited the lowest mean particle size $(13.20 \mu \mathrm{m})$ while the surface site on Sinking Creek had the highest $(725.2$ $\mu \mathrm{m})$. Particle size was not directly related to whether samples were collected from surface or cave sediments. A particle size scan revealed similar particle size distributions in all six samples (Figure 26).

Particle size did not seem to influence the calcium concentrations found in the digested sediments. Neither were calcium concentrations higher in extracts from sediments with small average particle size. 
Table 4. Calcium analyses of cave and surface water column samples.

\begin{tabular}{|l|l|r|}
\hline $\begin{array}{c}\text { COLLECTION } \\
\text { DATE }\end{array}$ & \multicolumn{1}{|c|}{$\begin{array}{c}\text { SAMPLE } \\
\text { DESCRIPTION }\end{array}$} & $\begin{array}{c}\text { CALCIUM } \\
\text { MG/L }\end{array}$ \\
\hline $3-18-99$ & Sinking Creek & 63.36 \\
\hline $3-18-99$ & Pen 1-Manhead & 53.97 \\
\hline $4-24-98$ & Sinking Creek & 53.09 \\
\hline $3-18-99$ & Pen 2-Rimstone & 50.91 \\
\hline $4-24-98$ & Pen 1-Manhead & 50.82 \\
\hline $4-24-98$ & Big Springs & 50.35 \\
\hline $4-24-98$ & Bandy Cave drip pool & 46.91 \\
\hline $2-24-01$ & Belt 1-H2O falls & 45.38 \\
\hline $2-24-01$ & Belt 2-Joe's Bar & 31.83 \\
\hline
\end{tabular}

Legend: The water column samples for calcium analyses were collected over the period from April 1998 to February 2001 in Breckinridge and Hardin counties, Kentucky. Calcium concentrations were measured by Flame Absorption Spectroscopy in the Environmental Analysis Laboratory at the University of Louisville. 
Figure 22. Graph of calcium levels in surface and cave water column samples.

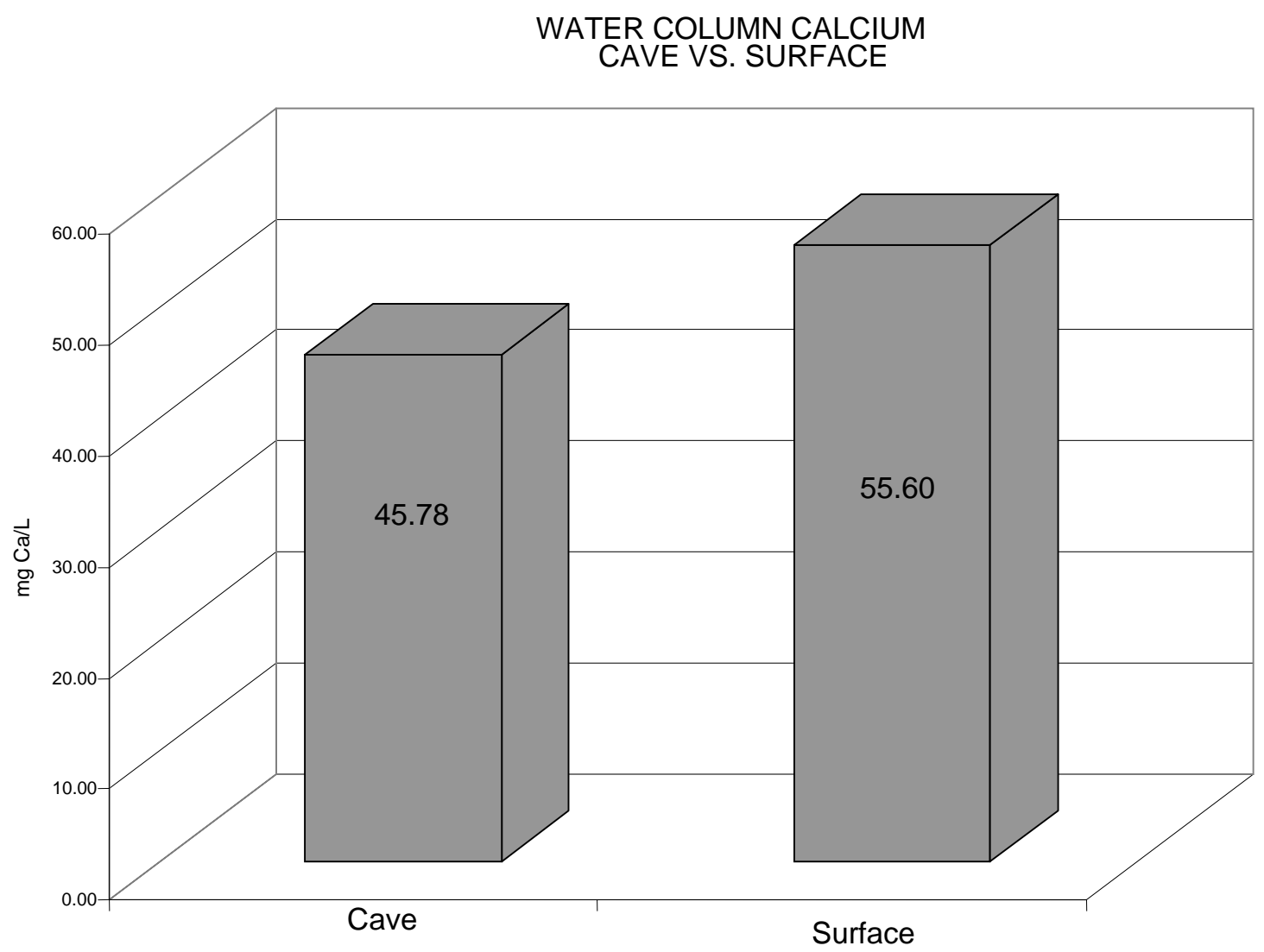

Legend: The graph shows averages for pooled values of samples collected between 1998 and 2002. Cave samples averaged 45.78 while surface samples had an average of 55.60 mg of calcium per liter of water column sample. 
Figure 23. Photo of sediment samples from Sinking Creek, Funks Run, and Belt 2 used for analysis.

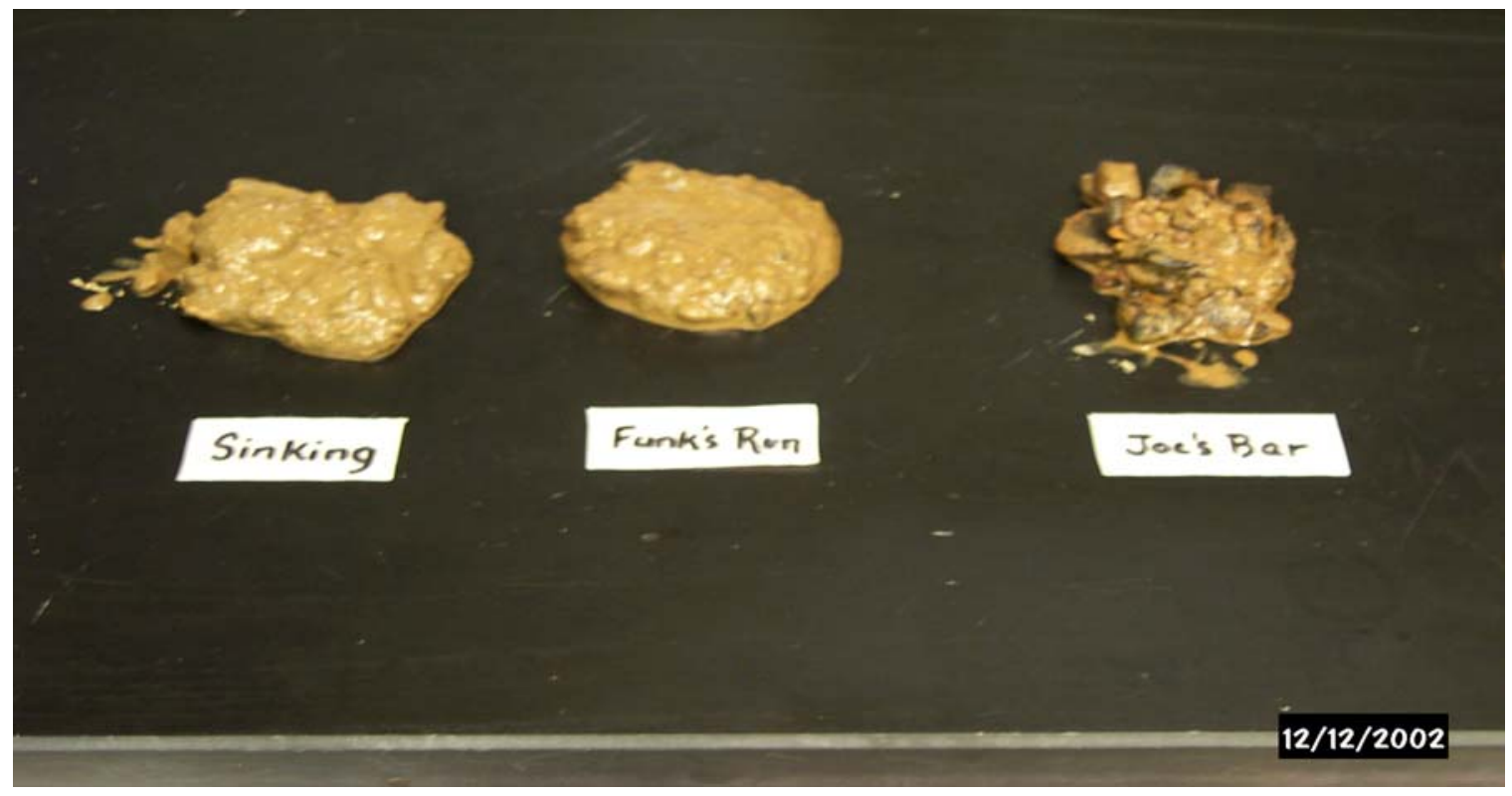

Legend: This is a photograph of sediment samples used for DNA extraction, particle size, and calcium analyses. From left to right: Sinking Creek (S), Funks Run (S), and Belt 2 (C) samples. Samples collected from the surface are denoted by (S) and cave samples by $(\mathrm{C})$. 
Figure 24. Photo of Belt 1, Pen 2, and Pen 1 sediments samples used for analysis.

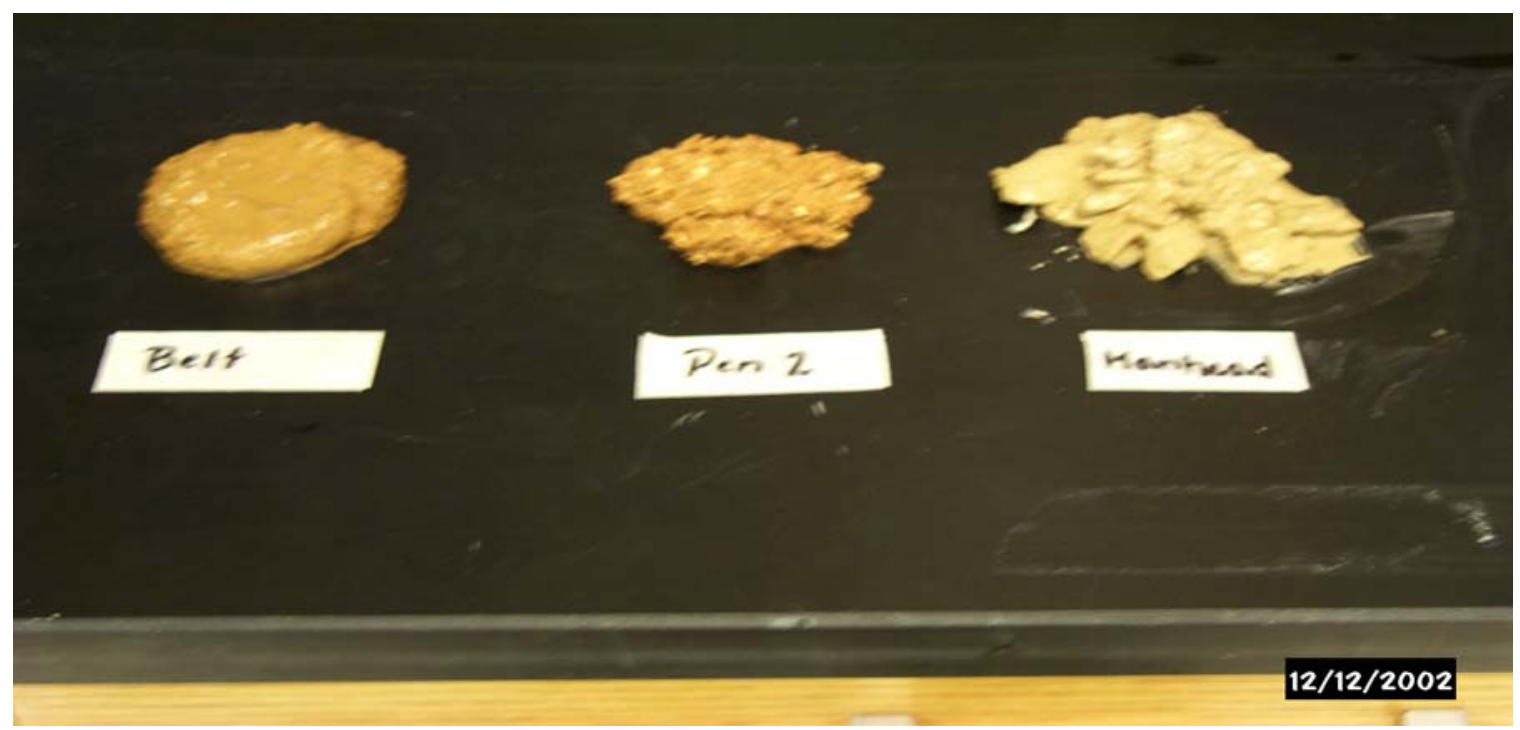

Legend: This is a photograph of sediment samples used for DNA extraction, particle size, and calcium analyses. From left to right: Belt 1, Pen 2, and Pen 1 samples. All samples in this photograph are cave sediment samples. 
Figure 25. Mean particle size of cave and surface sediments.

\section{PARTICLE SIZE}

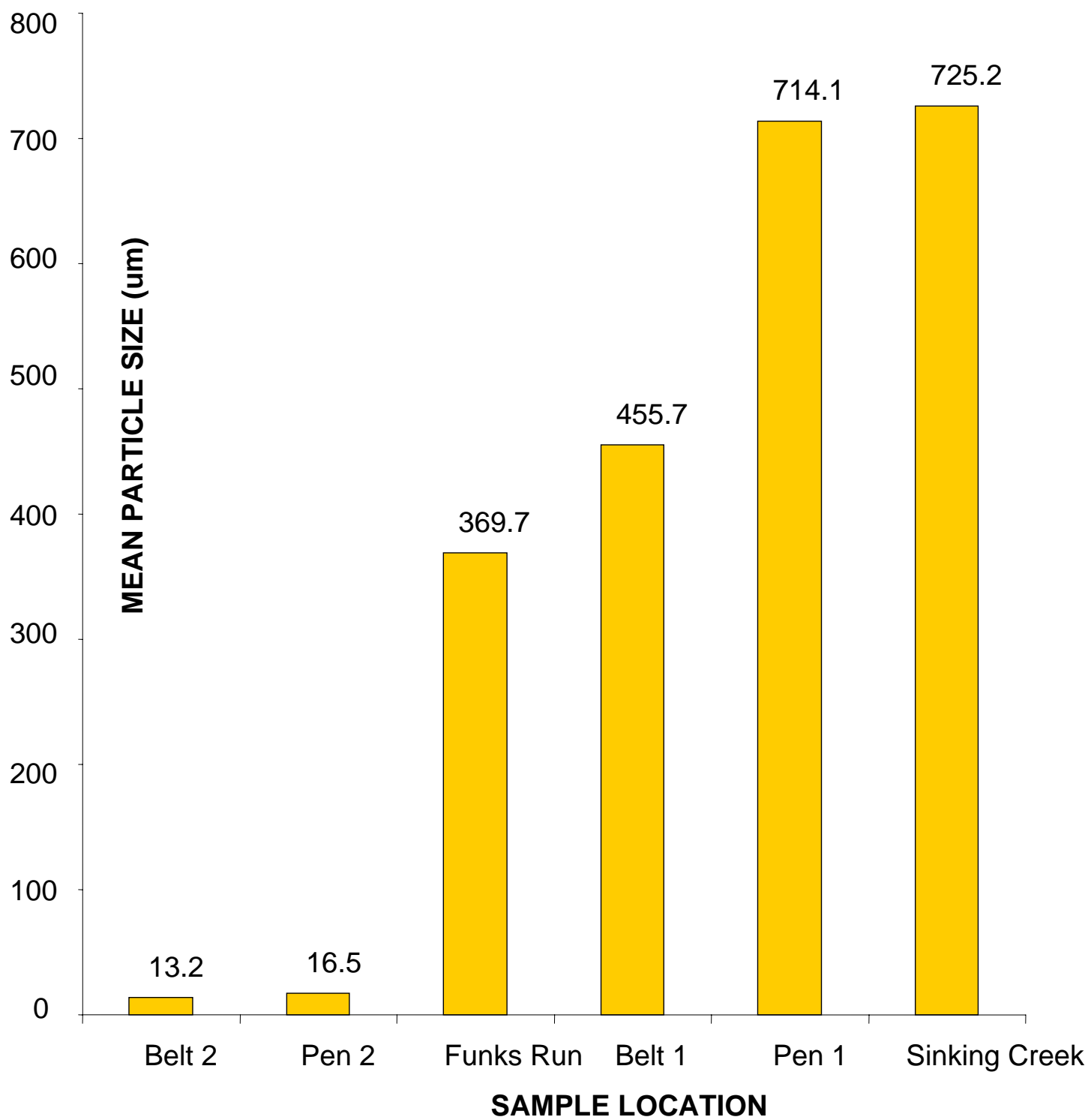

Legend: Mean particle size of samples collected in December, 2002. Samples were analyzed using laser technology by Dr. John Mang in the Robert Neiman Research Laboratory at Whip-Mix Corp., Louisville, KY 
Figure 26. Particle size scan of surface and cave sediments from 2,000 to $0.04 \mu \mathrm{m}$.

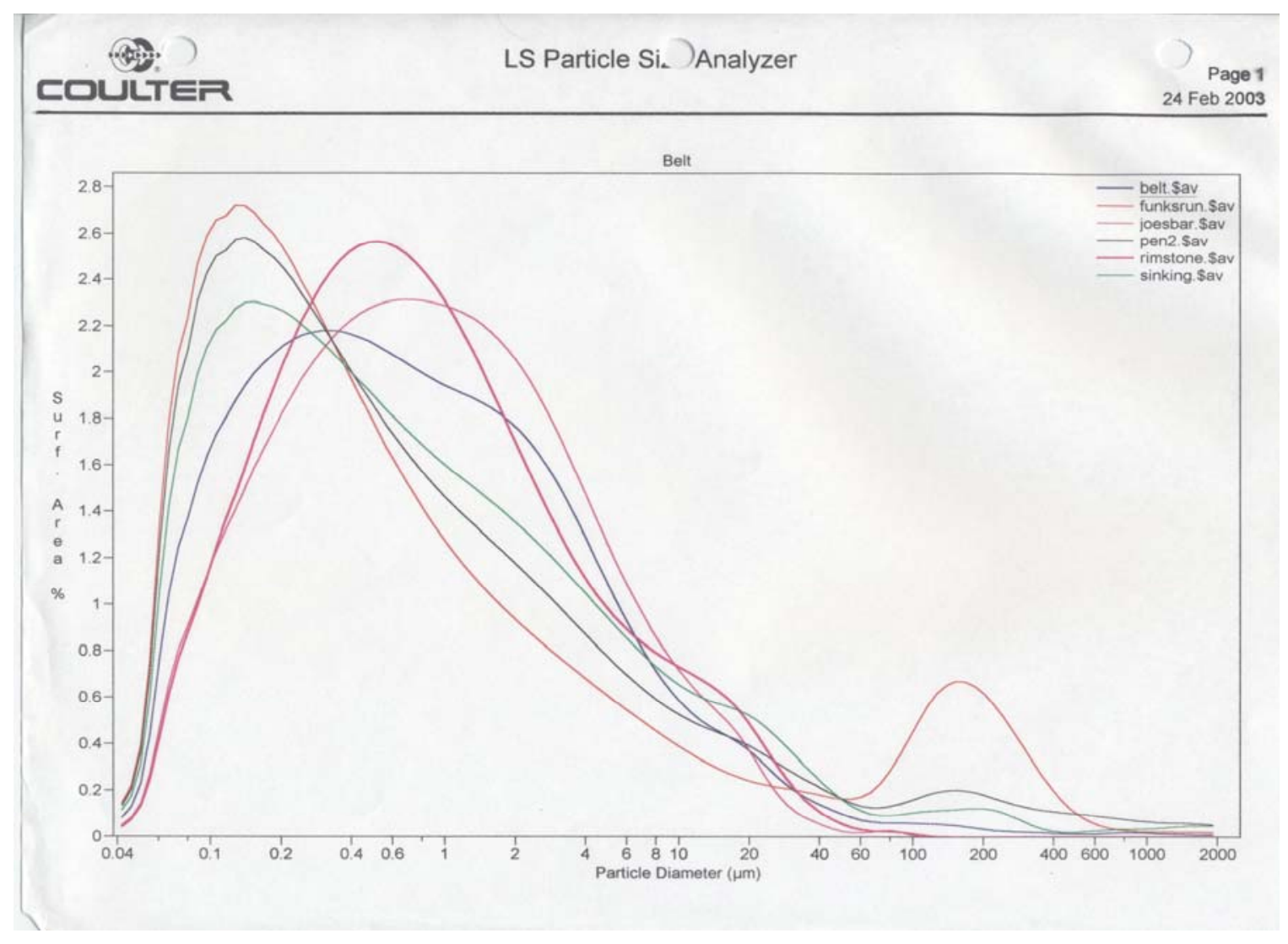

Legend: Particle size scan indicating the distribution of particle size and their contribution to surface area. Particle diameter is given in microns and is plotted against the percent of the total surface area which is made up of that size particles in the sample. 


\section{B. NUCLEIC ACIDS}

\section{EXTRACTION AND AMPLIFICATION}

Cultured communities from R2A plates were scraped and extracted by the modified BIO101 method without the addition of PVPP. Extracts were visualized by gel electrophoresis on $1 \%$ agarose and all extracts were visible and of adequate size for PCR amplification (Figure 27). Absorbance readings of plate cultured community extracts diluted 1/60 in 1XTNE supported visual results with Funks Run extract containing the lowest concentration of DNA (Table 5). All samples had calculated A260/A280 ratios lower than those of total community extracts from 10 grams of sediment. However, absorbance ratios of A260/A230 from cultured community extracts ranged from 1.53 to 1.98 , much higher than those directly extracted from sediments and all yielded product when $5 \mu \mathrm{l}$ of extract was used directly for PCR amplification.

While the in-situ extracted sediment samples from Penitentiary Cave yielded the lowest concentrations of DNA, all nucleic acid extracts were visible on $1 \%$ agarose (Figure 28). All samples yielded DNA of sufficient size for PCR amplification of the small subunit of the $16 \mathrm{~S}$ ribosomal gene. The sediments from Penitentiary Cave (Pen 1 and Pen 2) gave the lowest yield of DNA from 10 grams of sediment extracted by the Zhou et al. (1996) method (Table 6). Samples with the highest concentrations of DNA in extracts measured more than ten times those in Penitentiary Cave. Only the surface sample from Funks Run had a calculated 260/230 nm absorbance ratio of greater than 1.0 (1.05), still far below the standard for purity of 1.8 to 2.0 . Calculations of the 260/280 absorbance readings showed all samples between 1.16 and 1.32 compared to the standard for DNA purity (1.8-2.0). 
Figure 27. Photograph of cultured community extracts on $1 \%$ agarose gel.

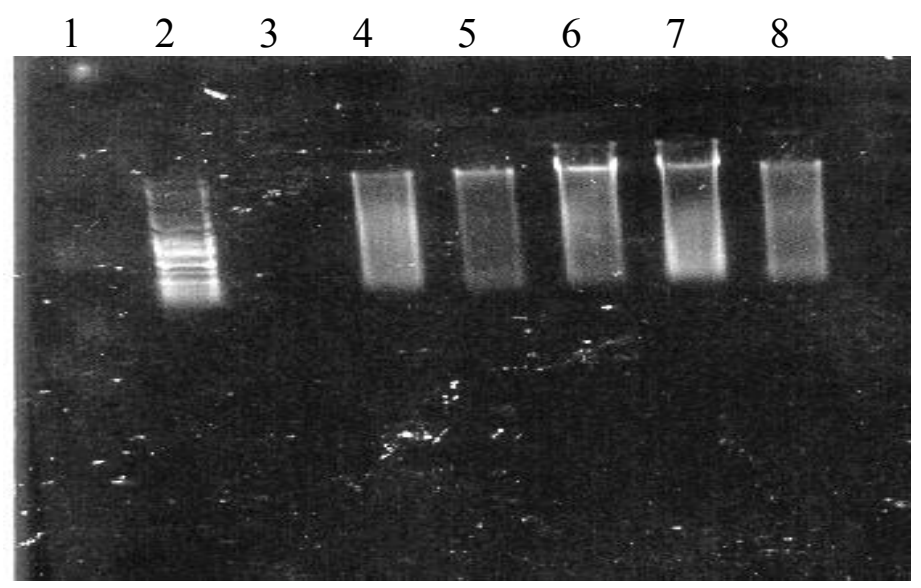

Legend: Thirteen $\mu 1$ of cultured plate extracts obtained by the modified BIO101 protocol. Ln 1-Blank; Ln 2-Hi-Lo standard (Minnesota Molecular); Ln 3-Extraction with no sample; Ln 4-Belt 1; Ln 5-Funks Run; Ln 6-Pen 2; Ln 7-Pen 1; Ln 8-Sinking Creek. 
Table 5. Yield and purity of plate cultured community extracts by absorbance spectrophotometry.

\begin{tabular}{|c|c|c|c|c|c|c|c|}
\hline Sample & 230nm & $260 \mathrm{~nm}$ & $280 \mathrm{~nm}$ & $325 \mathrm{~nm}$ & $\begin{array}{c}\text { Yield } \\
\mathrm{mg} / 100 \mu \mathrm{l}\end{array}$ & A260/A280 & A260/A230 \\
\hline 1XTNE & 0.0005 & 0.0003 & 0.0001 & 0.0002 & & & \\
\hline Sinking & 0.2532 & 0.0190 & 0.0124 & 0.0047 & 5.70 & 1.53 & 0.075 \\
\hline Funks & 0.1560 & 0.0079 & 0.0040 & 0.0006 & 2.37 & 1.98 & 0.051 \\
\hline Belt 1 & 0.0812 & 0.0168 & 0.0085 & 0.0001 & 5.04 & 1.98 & 0.207 \\
\hline Pen 1 & 0.1116 & 0.0424 & 0.0221 & 0.0020 & 12.72 & 1.92 & 0.380 \\
\hline Pen 2 & 0.2010 & 0.0545 & 0.0332 & 0.0110 & 16.35 & 1.64 & 0.271 \\
\hline
\end{tabular}

Legend: Readings at $260 \mathrm{~nm}$ are used for the calculation of DNA yield using the formula Absorbance of $1.0=50 \mathrm{mg} / \mathrm{ml}$ of DNA. Absorbance at $325 \mathrm{~nm}$ wavelength indicates particulates in the sample or dirty cuvettes. Ratios of A260/A280 and A260/A230 determine the purity of the DNA to be used for analysis based on the acceptable standard of calculated ratios of 1.8-2.0. 
Figure 28. Photo of agarose gel containing DNA extracts from 10 grams of surface and cave sediments.

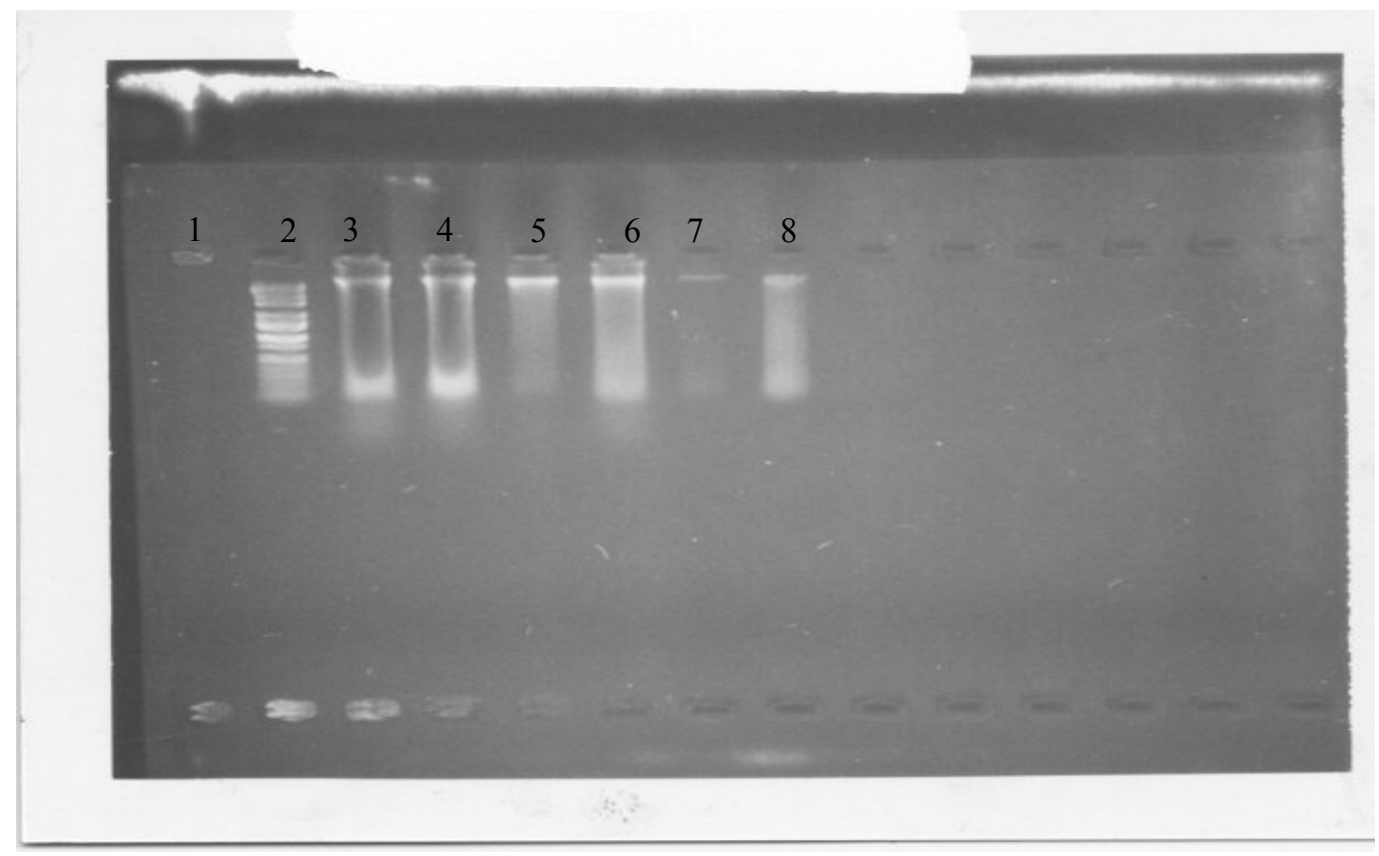

Legend: Each lane contains $18 \mu \mathrm{l}$ of DNA extract from 10 grams (wet weight) of sediment with 2 ul loading dye except where noted. Samples were electrophoresed on 1\% agarose gel and the presence of nucleic acids is indicated in all lanes. Lane 1 was left blank as a control. Ln 2-Hi-Lo Standard (6 $\mu 1$, Minnesota Molecular), Ln 3-Sinking Creek (S), Ln 4-Funks Run (S), Ln 5-Belt 2, Ln 6-Belt 1, Ln 7-Pen 1, Ln 8-Pen 2. Surface samples are indicated by an (S) following the sample designation. 
Table 6. Yield and purity of DNA extracts from sediment samples.

\begin{tabular}{|l|r|r|c|}
\hline \multicolumn{1}{|c|}{ SAMPLE } & A260/A230 & A260/A280 & Yield (mg/ml) \\
\hline Belt 1 & 0.85 & 1.16 & 406.6 \\
\hline Sinking Ck & 0.97 & 1.25 & 371.8 \\
\hline Funks Run & 1.05 & 1.31 & 363.0 \\
\hline Belt 2-J & 0.92 & 1.22 & 79.1 \\
\hline Pen 2 & 0.82 & 1.20 & 28.6 \\
\hline Pen 1 & 0.89 & 1.32 & 24.8 \\
\hline
\end{tabular}

Legend: Low ratios of A260/A230 indicate contamination by phenols, humic and other organic acids, and other cyclic compounds. Solutions of calcium chloride and calcium carbonate in this study also absorbed at a peak of $258 \mathrm{~nm}$. The A260/A280 ratios are measures of contamination by cellular proteins and RNA. Yields given are from 10 gram (wet weight) extractions. 
Actual yields of DNA far exceeded predicted yields based on direct cell counts from the sample sediments (Table 7). Yields were not related to the concentrations of calcium in the sediments nor the average particle size of the sediment sampled.

To ensure that primers were suitable for amplifying the cave bacteria, Eub 1/Eub 2 primer pair was used with template from cultured communities and total direct extracted DNA. When the entire $50 \mu 1$ of PCR product was visualized in $1.5 \%$ agarose, total community extracts by direct in-situ extraction yielded only slight bands compared to that from cultured bacteria (Figure 29). However, DNA template was not standardized between samples and yields from direct extraction of cave sediments averaged 179.25 $\mathrm{mg} / \mathrm{mL}$ compared to an average of $307.5 \mathrm{mg} / \mathrm{mL}$ for extracts from the cultured bacteria. While there was only one surface sample, extract from the surface sample was equivalent in concentration to those from the cultured communities at $279.75 \mathrm{mg} / \mathrm{mL}$ but produced the faintest band by gel electrophoresis. Although products were of different sizes, the three primer pairs evaluated in this study did not effect the success of PCR. Positive controls of Rhodococcus rhodochrous DNA extracted by the same methods as the sediment samples were successfully amplified by all primer pairs used in this study (results not shown).

When template DNA from E. coli cells co-extracted with a sediment sample from Penitentiary Cave (Pen 1$)$ was used $(1 \mu 1)$, along with cave and E .coli DNA separately, (BIO101 Protocol, $0.500 \mathrm{gm}$ ), with universal primers (UniF and UniR) amplification was inhibited in all samples except $E$. coli DNA extracted alone. While there was adequate DNA for amplification from all samples measured by absorbance spectrophotometry, all samples containing cave sample extract did not produce a PCR 
Table 7. Actual and theoretical yields of DNA from collected sediment samples.

\begin{tabular}{|l|l|l|}
\hline \multicolumn{1}{|c|}{ SAMPLE } & $\begin{array}{c}\text { ACTUAL } \\
\text { YIELD }\end{array}$ & $\begin{array}{c}\text { THEORETICAL } \\
\text { YIELD }\end{array}$ \\
\hline Belt 1 & $4.066 \times 10^{12}$ & $3.67 \times 10^{7}$ \\
\hline Sinking Ck & $3.718 \times 10^{12}$ & $2.16 \times 10^{7}$ \\
\hline Funks Run & $3.630 \times 10^{12}$ & $3.55 \times 10^{7}$ \\
\hline Belt 2 & $7.910 \times 10^{11}$ & $1.71 \times 10^{7}$ \\
\hline Pen 2-R & $2.860 \times 10^{11}$ & $5.83 \times 10^{7}$ \\
\hline Pen 1-M & $2.480 \times 10^{11}$ & $1.10 \times 10^{6}$ \\
\hline
\end{tabular}

Legend: Both theoretical yields and actual yields are given in $\mathrm{pg} / 10 \mathrm{gm}$ sediment Extraction efficiency was inestimable by the method chosen. 
Figure 29. Comparison of PCR product from cultured bacteria extracts or from in-situ extracted sediments.

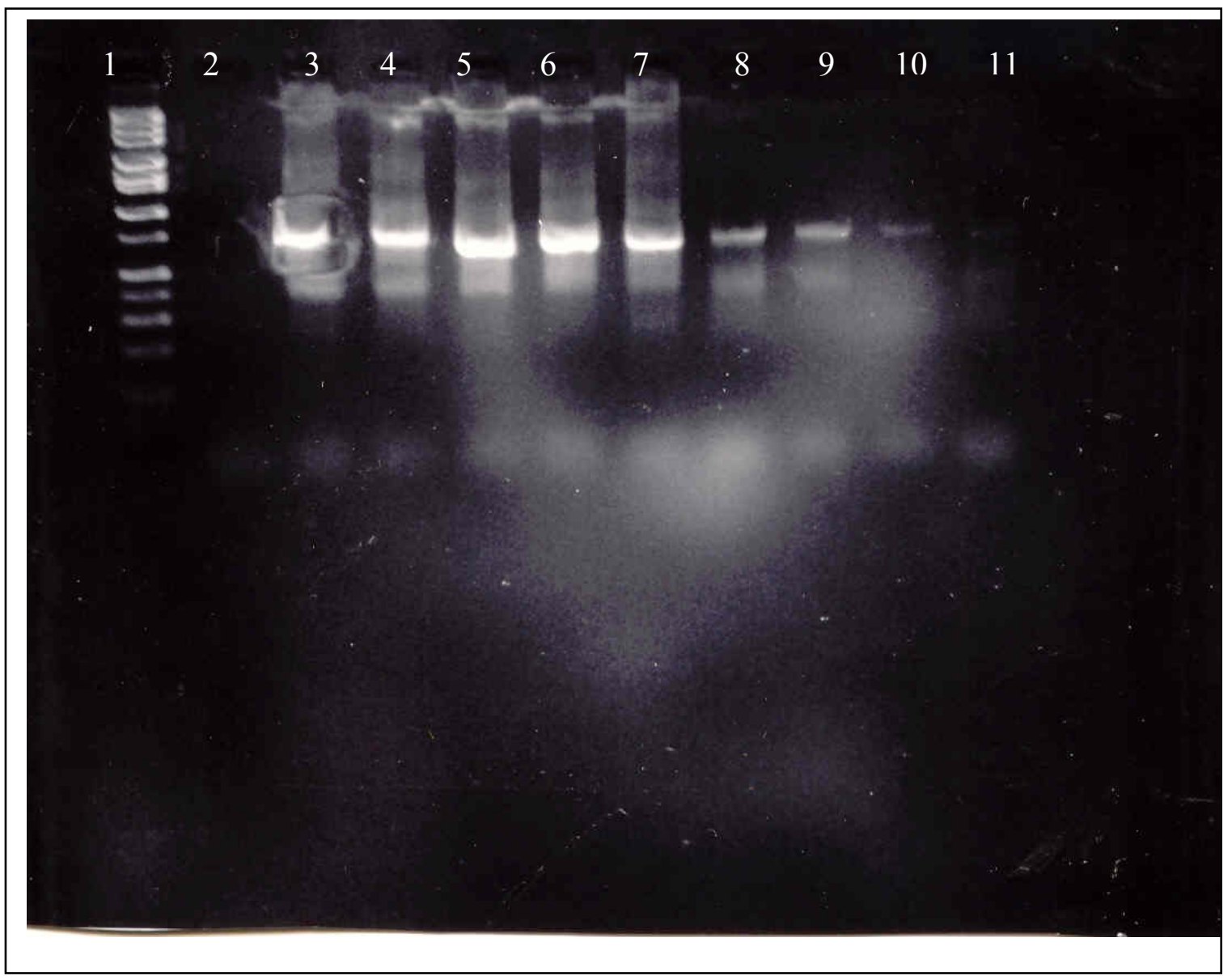

Legend: Total volume of $50 \mu 1$ from PCR of extracts of various cultured and in-situ extracted sediment samples on $1.5 \%$ agarose. One ul of each extract was used as template with the primer pair Eub1 and Eub2. The extracts from cultured bacteria produced significantly more product than those from in-situ extracted sediments. Ln1Hi-Lo Standard; Ln2-blank; Ln3-Plate\#3; Ln4-Plate\#6; Ln5-Plate\#9; Ln6-Plate\#18; Ln7Plate\#22; Ln8-S2 sediment extract; Ln9-S3 sediment extract; Ln10-S5 sediment extract; Ln11-surface sediment extract. 
product (Figure 30).

Separate experiments demonstrated that sediment extract (Belt 2) inhibited PCR amplification of ribosomal DNA from E. coli even when diluted. Amplification of 16S DNA from E. coli was inhibited when spiked with $5 \mu 1$ of cave extract diluted $10^{-2}$ but not at dilutions of $10^{-3}$ (Figure 31).

In addition to the water column calcium concentrations presented previously, calcium levels were compared in DNA extracts (0.500 gm BIO101 method) of sediment from Sinking Creek and Belt Cave collected in January, 2000 . Levels of calcium (mg Ca/L) were lower in Sinking Creek (surface) sediment extract $(8.98 \mathrm{mg} / \mathrm{L}$ ) than in two separate extractions from a Belt Cave sediment sample (14.09 and $13.37 \mathrm{mg} / \mathrm{L}$ respectively).

Calcium analyses (Table 8) were performed again in October of 2002 on both sediment samples and DNA extracts. Calcium was measured from sediment samples and extracts from those same sediments (Figure 32). When sediments were digested for calcium analysis there was a large variance between samples ( 0.67 to 282.74 mg Ca/gm sediment wet wt.). After extraction of $10 \mathrm{gm}$ of sediment by the modified Zhou et al. (1996) protocol, all sediment and extract samples were analyzed. There was a significant decrease in all extracts except Belt 2 when compared to the sediments from which they were extracted. Belt 2 sediment, which had a calcium concentration of only $0.67 \mathrm{mg} \mathrm{Ca} / \mathrm{gm}$ in the digested sediment sample before extraction, showed an increase in calcium concentrations in the nucleic acid extract. Sediments and extracts were compared using a two-tailed paired t-test $(\mathrm{p}<0.001)$. Homogeneity of variances test statistic was calculated from $\mathrm{s}_{2}{ }^{2} / \mathrm{s}_{1}{ }^{2}=2.32\left(\mathrm{~F}_{.05,5,5}=7.15\right)$ Although wavelength scans of several dilutions of a calcium carbonate solution showed absorbance peaks near $230 \mathrm{~nm}$, there was no correlation ( $\mathrm{r}=-0.3203)$ between A260/A230 ratios when compared to 
Figure 30. Co-extraction of E. coli and cave sediment compared to mixing E. coli and cave sediment extract after extraction and the effects on successful PCR amplification.

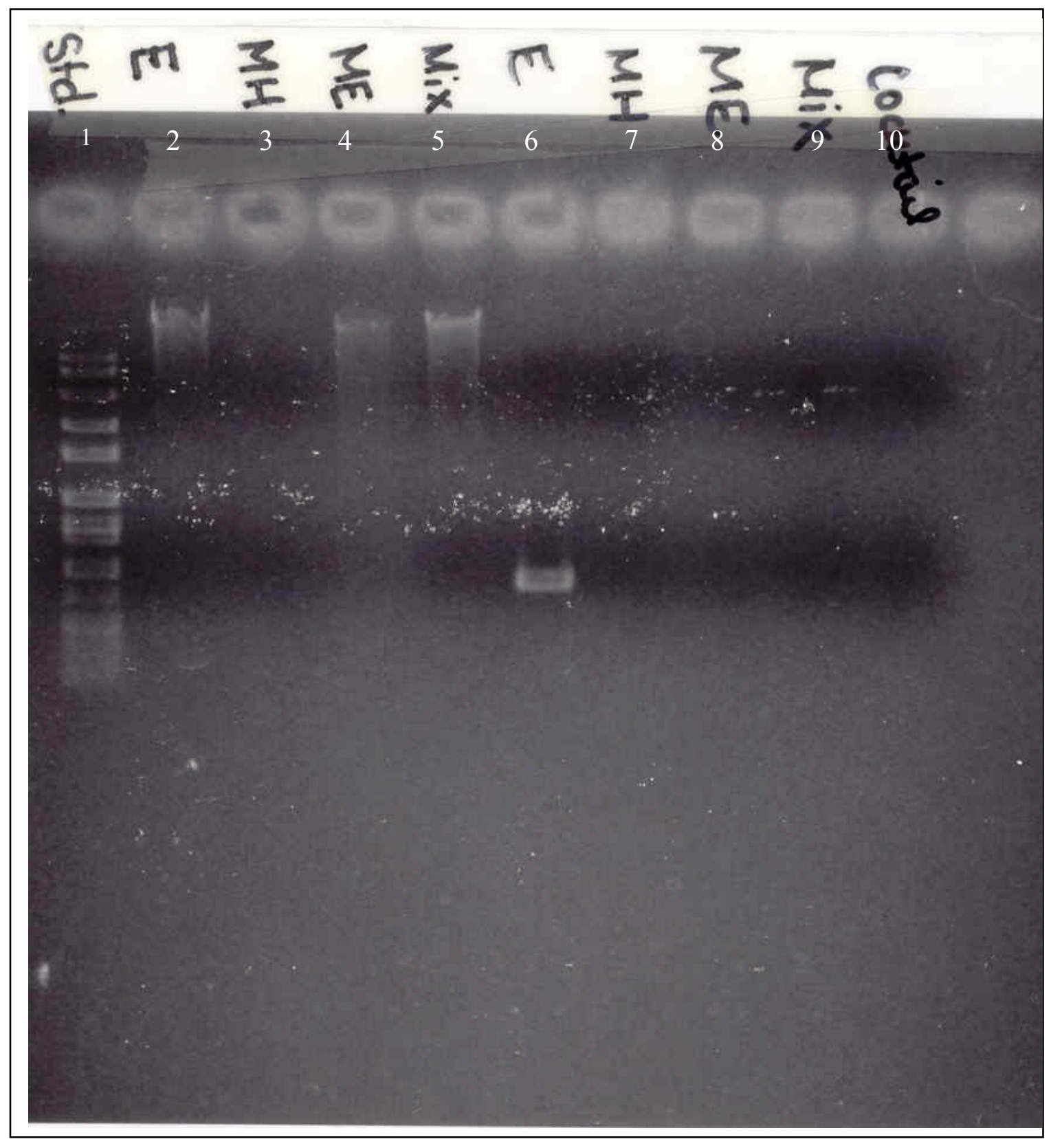

Legend: Ln1-Hi-Lo Std.; Ln2-E. coli extract; Ln3-Penitentiary Cave extract alone; Ln4-Penitentiary Cave and E. coli extracted together; Ln5-Penitentiary Cave extract and E. coli extracts mixed (1:1) after extraction; Lanes 6-10 indicate the PCR products from all extracts shown in addition to a no template added control. The top two bands of the Hi-Lo Standard are equivalent to sizes of $10000 \mathrm{bp}$ and $8000 \mathrm{bp}$. 
Figure 31. Amplification of $16 \mathrm{~S}$ rDNA from E. coli when spiked with cave sediment extracts.

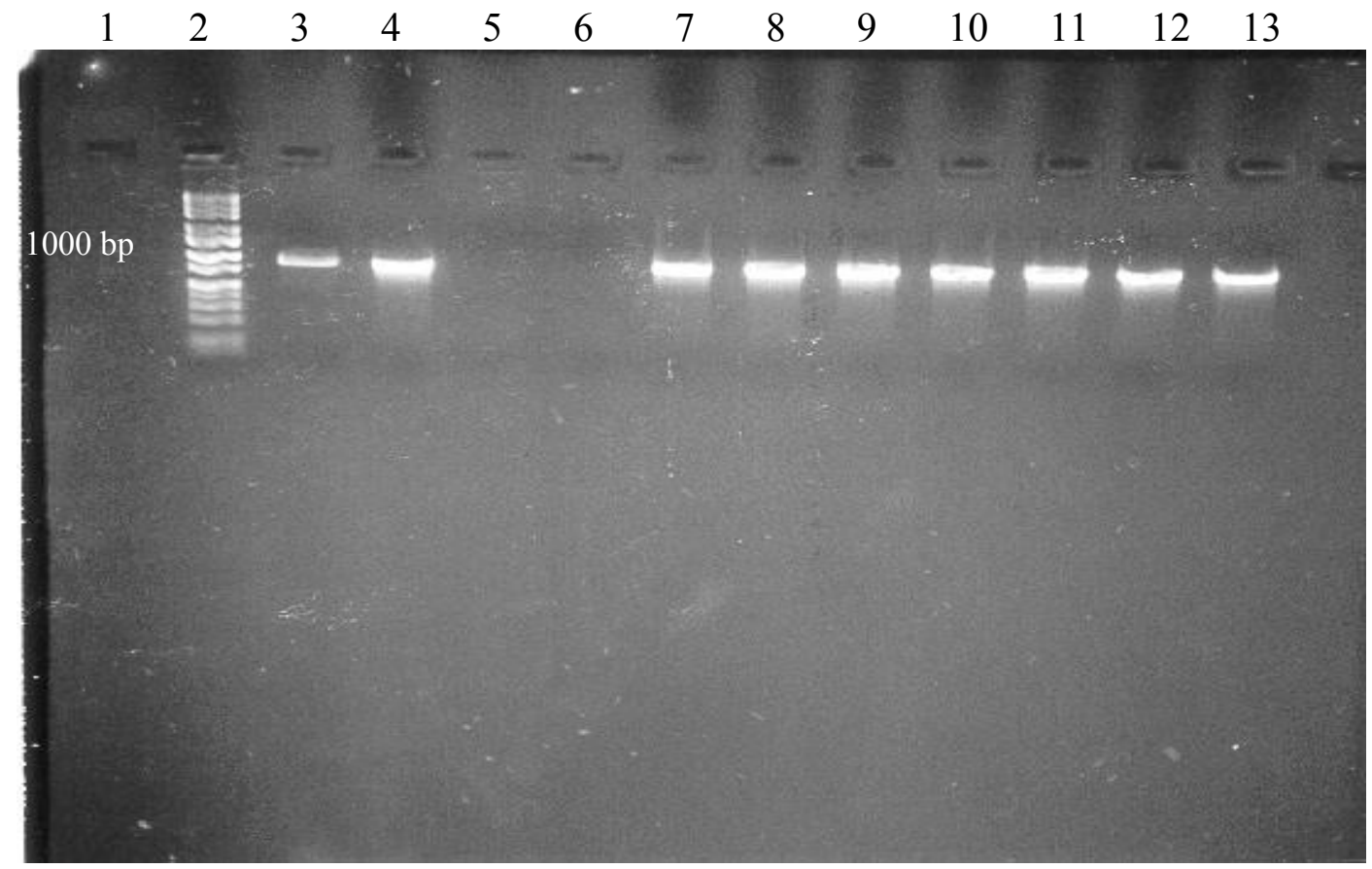

Legend: Template was E. coli DNA ( $1 \mu 1$ of extract) and reactions were spiked with $5 \mu 1$ diluted Belt 2 extract. Ln1-Blank; Ln2-Hi-Lo standard (Minnesota Molecular); Ln3cocktail with no template added; Ln4-E.coli template alone; Ln5-E. coli with Belt 2 diluted 1/2; Ln6-E. coli with Belt 2 diluted 1/10; Ln7-E. coli with Belt 2 diluted 10 $0^{-3}$; Ln8-E. coli with Belt 2 diluted 10-5; Ln9-E. coli with Belt 2 diluted 10-6; Ln10-E. coli with Belt 2 diluted $10^{-7}$; Ln11-E. coli with Belt 2 diluted $10^{-8} ;$ Ln12-E. coli with Belt 2 diluted $10^{-9}$; Ln13-E. coli with Belt 2 diluted $10^{-10}$. 
Table 8. Calcium levels in digested sediments and DNA extracts.

\begin{tabular}{|l|c|c|}
\hline \multicolumn{1}{|c|}{ Sample } & $\begin{array}{c}\text { Ca in Sediment } \\
(\mathrm{mg} / 10 \text { gm wet wt. })\end{array}$ & $\begin{array}{l}\text { Ca in Extract } \\
(\mathrm{mg} / 1000 \mu \mathrm{l})\end{array}$ \\
\hline Pen 1 & 2827.4 & 71.73 \\
\hline Belt 1 & 694.2 & 56.01 \\
\hline Funks Run & 313.2 & 43.98 \\
\hline Pen 2 & 207.4 & 53.13 \\
\hline Sinking Creek & 50.5 & 23.16 \\
\hline Belt 2 & 6.7 & 40.12 \\
\hline
\end{tabular}

Legend: These calcium analyses were performed in the Environmental Analysis Laboratory at the University of Louisville. Levels were measured using Standard Methods for Flame Absorption Spectroscopy (Greenburg 1998). One thousand microliters of extract contained the DNA and co-extracted compounds from 10 grams of sediment. 
Figure 32. Comparison of calcium levels in sediments and extracts from those sediments.

\section{SEDIMENTS VS. 10 GMEXTRACTS}

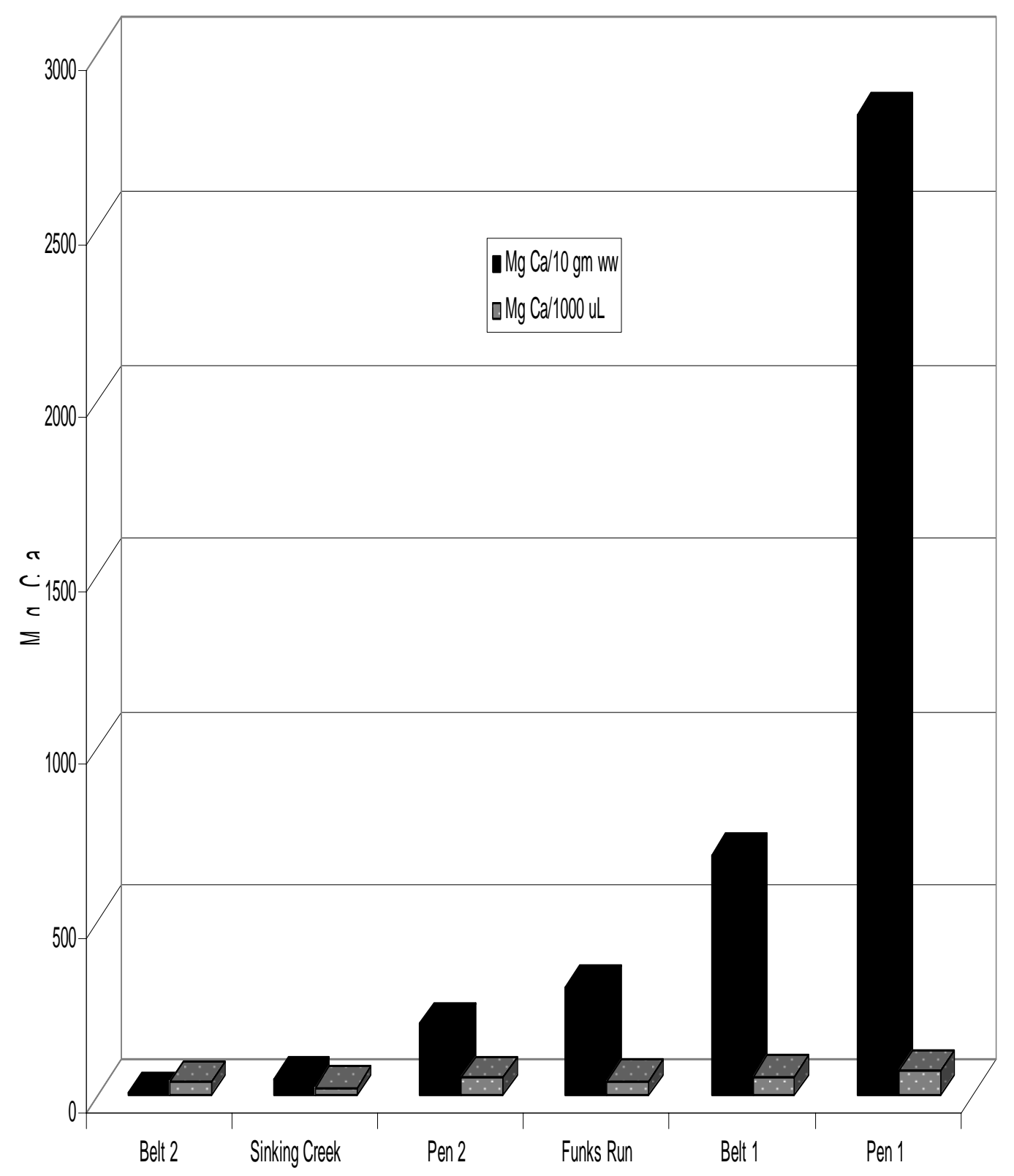

Legend: Calcium was measured in sediments and in extracts of 10 grams by a modified Zhou (1996) protocol. Values for sediments are given in $\mathrm{mg} \mathrm{Ca} / 10$ grams wet wt. of sediment. Values for the extracts are given in $\mathrm{mg} \mathrm{Ca} / \mathrm{mL}$. 
calcium levels in the extracts.

Experiments using E. coli DNA with Taq polymerase or $r T$ th polymerase and varying concentrations of calcium chloride in PCR reactions revealed that $r$ Tth polymerase yielded product with slightly higher concentrations of calcium chloride. Also, all products were cleaner, with no non-specific product or multiple bands visible on agarose gel (results not shown).

The inhibition of PCR experiments showed that calcium does play a role in inhibiting amplification. Initial experiments using rTth polymerase and extracts from either E. coli or Belt 2 as template showed E. coli to be inhibited by the addition of between 50 and $5 \mathrm{mM}$ concentrations of calcium chloride $\left(\mathrm{CaCl}_{2}\right)$. The Belt Cave sample was inhibited at concentrations of calcium chloride between $5 \mathrm{mM}$ and $1 \mathrm{mM}$. A repeat of this experiment using lower concentrations of $\mathrm{CaCl}_{2}$, showed inhibition of PCR amplification from E. coli DNA at concentrations of 8mM (Figure 33), and between $4 \mathrm{mM}$ and $6 \mathrm{mM}$ concentrations when using $3 \mu 1$ of total community DNA from Belt 2 sediment (Figure 34). After amplification, there was a white precipitate in all tubes from $3 \mathrm{mM}$ up for E. coli reactions. Upon observation of tubes containing Belt 2 DNA template, only the $1 \mathrm{mM} \mathrm{CaCl}_{2}$ tube did not contain a white precipitate.

When reactions were spiked with calcium carbonate, amplification of the $16 \mathrm{~S}$ ribosomal gene from E. coli was not inhibited even by the addition of a saturated calcium carbonate solution (Figure 35). Amplification of rDNA from the extract of cultured cave bacteria (plate \#22) was only slightly inhibited (Figure 36). However, spiking experiments with calcium carbonate were not performed using cave sediment extracts. Methods of extraction and purification did affect the success of PCR amplification from sediments in this study (Figure 37). DNA extracted from E. coli yielded PCR product 
Figure 33. Inhibition of PCR amplification from E. coli DNA by the addition of increasing concentrations of calcium chloride.

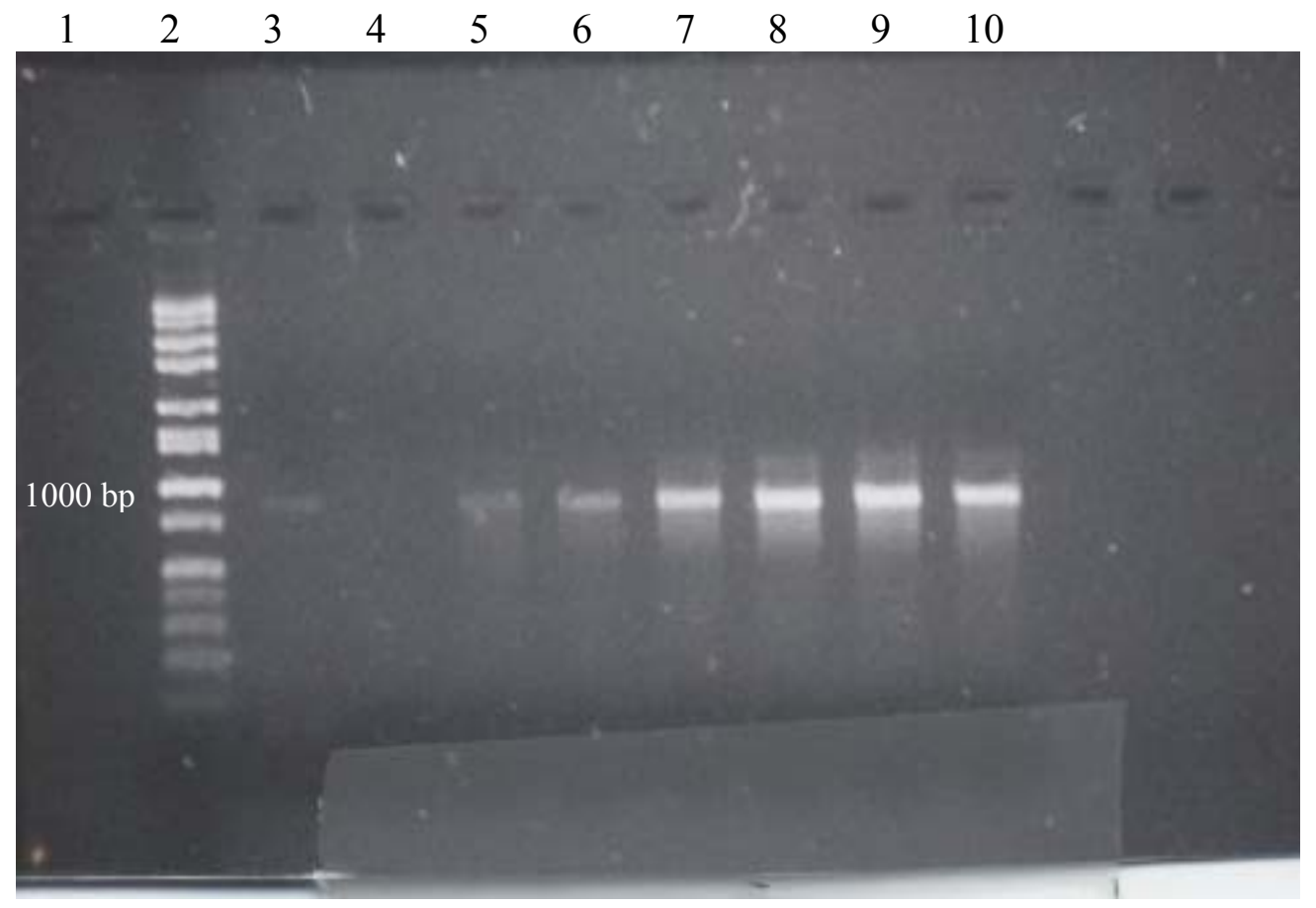

Legend: Template used was E. coli DNA ( $1 \mu 1$ of extract) and $50 \mu 1$ reactions were spiked with $10 \mu \mathrm{l}$ of a calcium chloride solution. Concentrations of calcium chloride given is the final concentration in PCR tubes. Ln1-Blank; Ln2-Hi-Lo Standard (Minnesota Molecular); Ln3-cocktail with no template added; Ln4-E. coli with $10 \mathrm{mM}$ $\mathrm{CaCl}_{2}$; Ln5-E. coli with $8 \mathrm{mM} \mathrm{CaCl}_{2}$; Ln6-E. coli with $6 \mathrm{mM} \mathrm{CaCl}_{2}$; Ln7-E. coli with 4 $\mathrm{mM} \mathrm{CaCl} 2$; Ln8-E. coli with $3 \mathrm{mM} \mathrm{CaCl}_{2} ; \mathrm{Ln} 9-E$. coli with $2 \mathrm{mM} \mathrm{CaCl}_{2} ; \mathrm{Ln} 10-1 \mathrm{mM}$ $\mathrm{CaCl}_{2}$. 
Figure 34. Inhibition of PCR amplification from a cave sediment extract by the addition of increasing concentrations of calcium chloride.

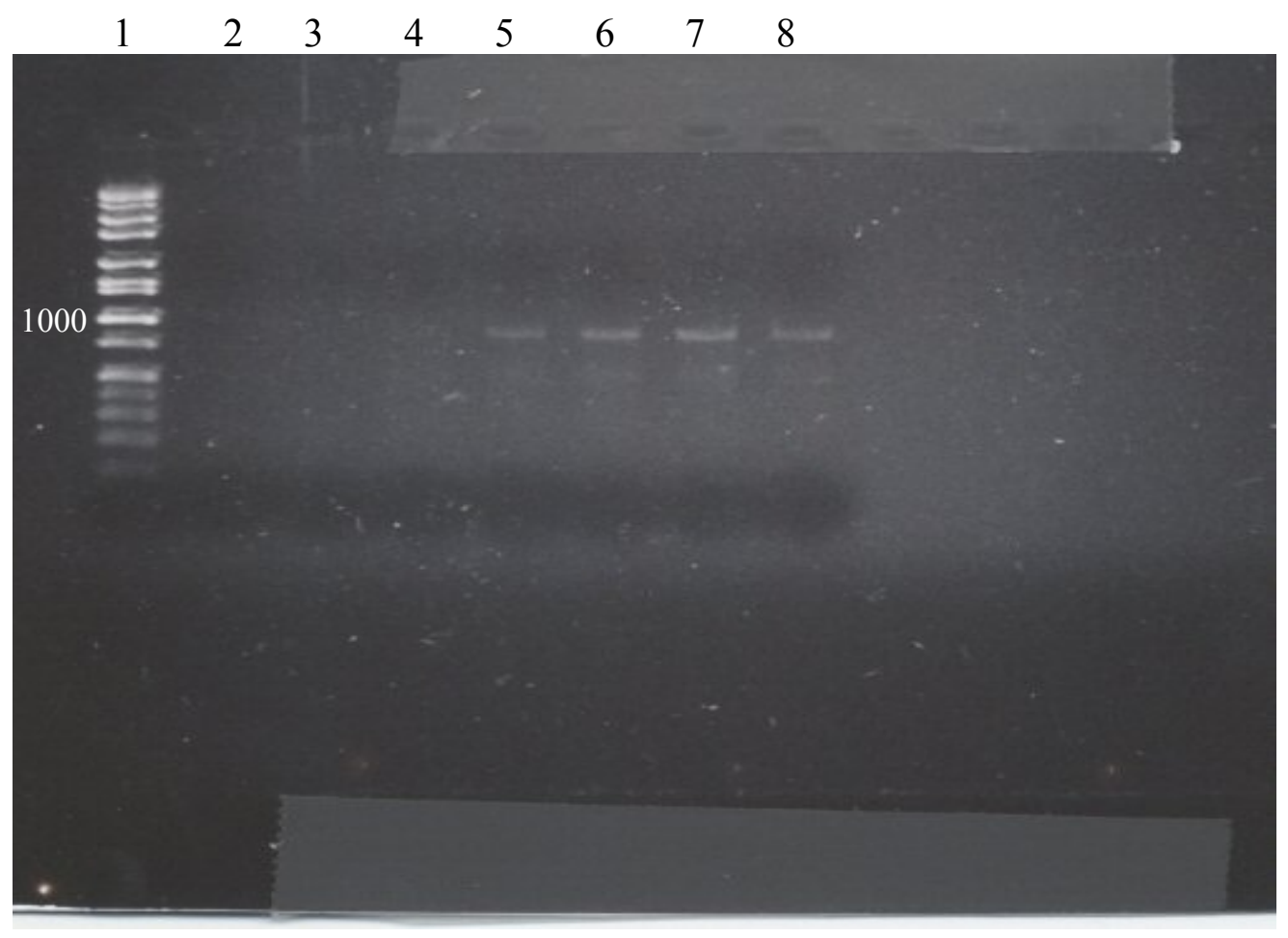

Legend: Template was Belt 2 DNA $\left(1 \mu\right.$ of extract diluted $\left.10^{-2}\right)$ and reactions were spiked with the same calcium chloride solutions used in the E. coli inhibition experiment. Concentrations given are final concentrations in PCR tubes. There is no negative control shown as the cocktail was observed with the E. coli inhibition experiment. Ln1-Hi-Lo standard (Minnesota Molecular); Ln2-Belt 2 with $10 \mathrm{mM} \mathrm{CaCl}_{2}$; Ln3-Belt 2 with $8 \mathrm{mM}$ $\mathrm{CaCl}_{2}$; Ln4-Belt 2 with $6 \mathrm{mM} \mathrm{CaCl}_{2}$; Ln5-Belt 2 with $4 \mathrm{mM} \mathrm{CaCl}_{2}$; Ln6-Belt 2 with 3 $\mathrm{mM} \mathrm{CaCl}_{2}$; Ln7-Belt 2 with $2 \mathrm{mM} \mathrm{CaCl}_{2}$; Ln8-Belt 2 with $1 \mathrm{mM} \mathrm{CaCl}_{2}$. 
Figure 35. Effect of increasing concentrations of calcium carbonate on the successful amplification of $16 \mathrm{~S}$ rDNA from E. coli template.

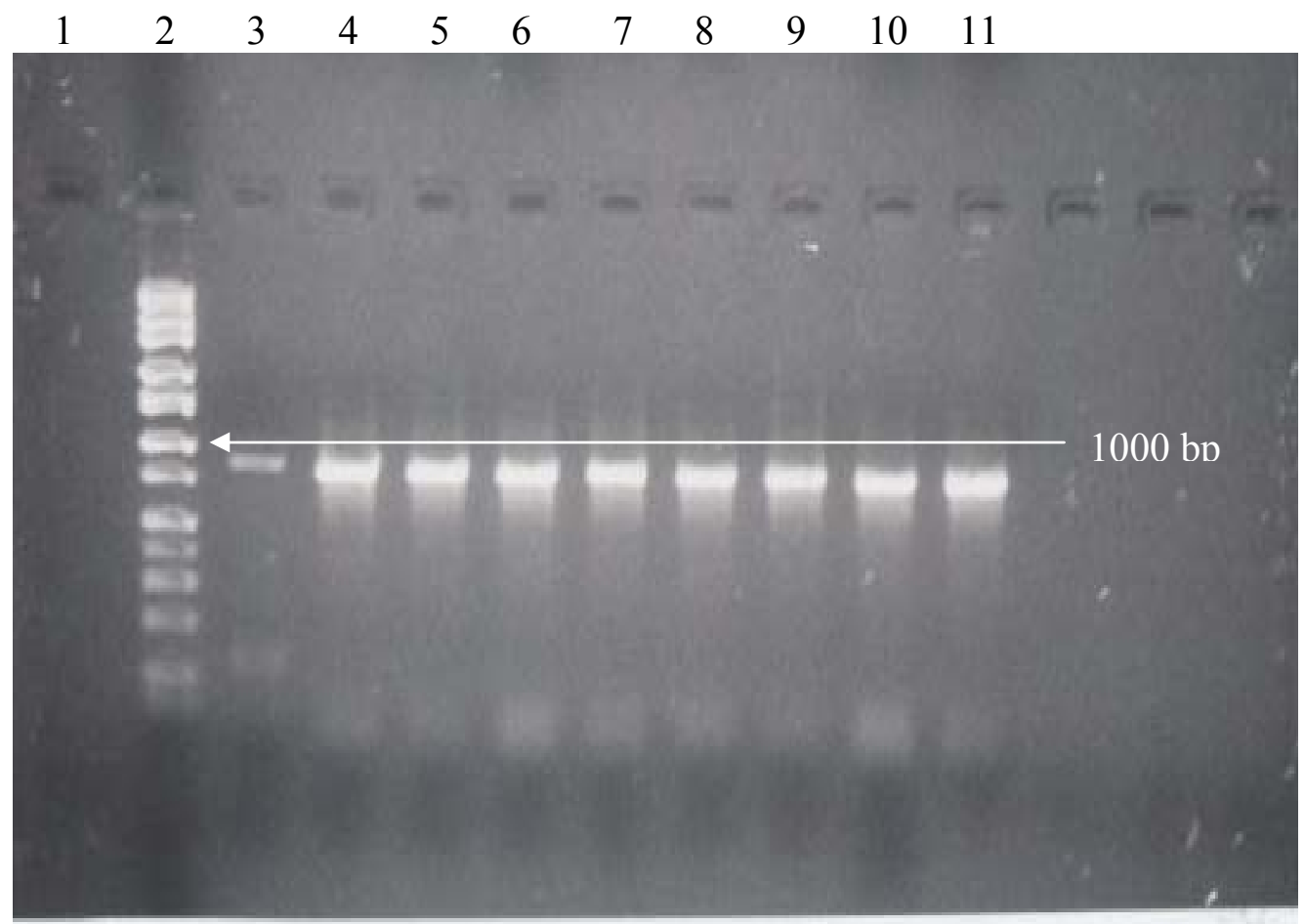

Legend: (Experiment 4). Template was E. coli DNA (1 $\mu 1$ of extract) and reactions were spiked with $5 \mu$ of a saturated calcium carbonate $\left(\mathrm{CaCO}_{3}\right)$ solution or dilutions of that same solution. Ln1-Blank; Ln2-Hi-Lo standard (Minnesota Molecular); Ln3-cocktail with no template added; Ln4-E. coli with saturated $\mathrm{CaCO}_{3}$ solution; Ln5-E. coli with $\mathrm{CaCO}_{3}$ diluted 1/2; Ln6-E. coli with $\mathrm{CaCO}_{3}$ diluted 1/4; Ln7-E. coli with $\mathrm{CaCO}_{3}$ diluted 1/10; Ln8-E. coli with $\mathrm{CaCO}_{3}$ diluted 1/20; Ln9-E. coli with $\mathrm{CaCO}_{3}$ diluted 1/40; Ln10-E. coli with $\mathrm{CaCO}_{3}$ diluted 1/100; Ln11-E. coli alone. 
Figure 36. Effect of increasing concentrations of calcium carbonate on the successful amplification of $16 \mathrm{~S}$ rDNA from cave microbes cultured in the cave environment on soil agar.

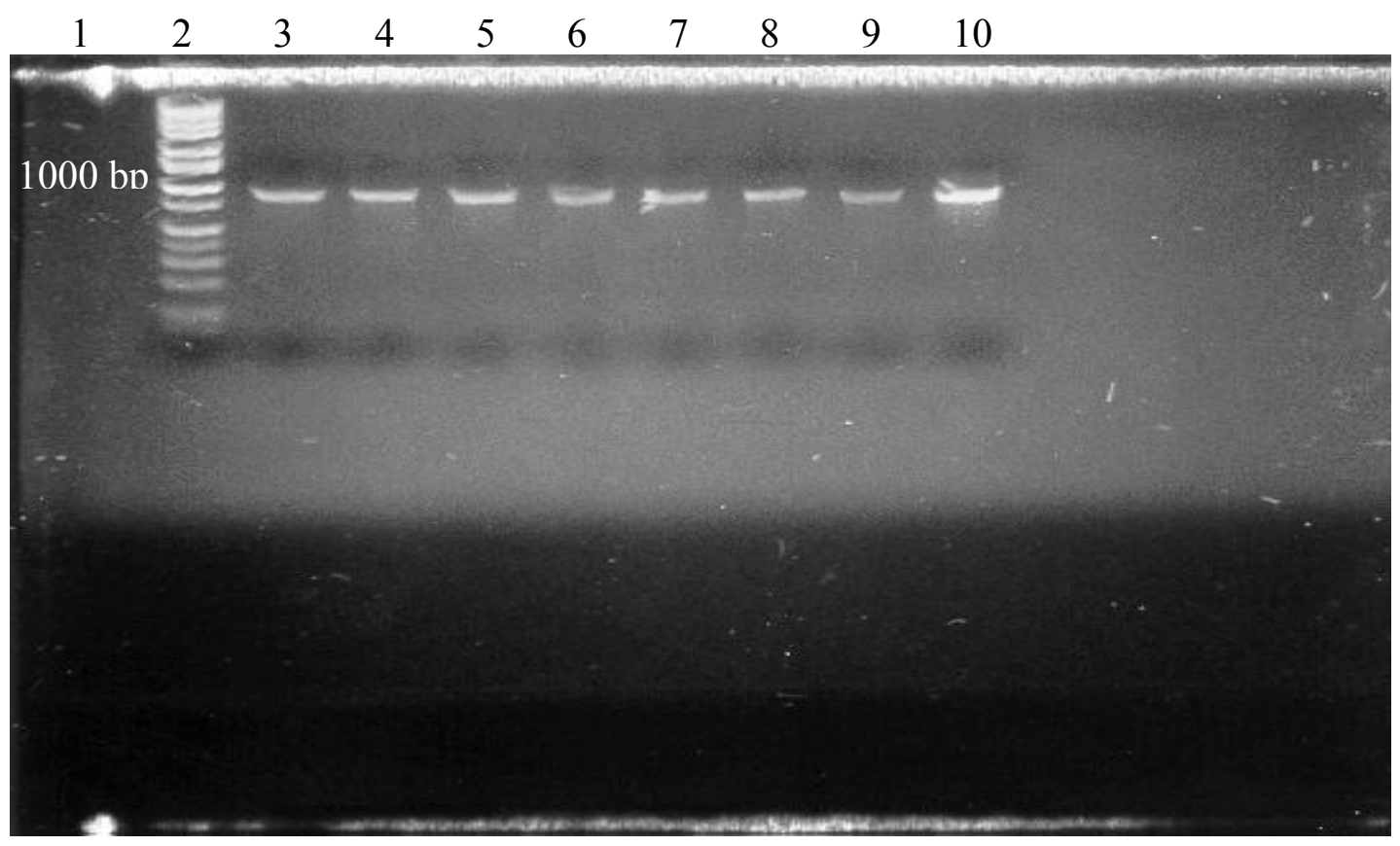

Legend: Template was DNA from Belt 2 (plate \#22) cultured community $(1 \mu$ l of extract) and reactions were spiked with $5 \mu 1$ of a saturated calcium carbonate $\left(\mathrm{CaCO}_{3}\right)$ solution or dilutions of that same solution. Ln 1-Blank; Ln2-Hi-Lo Standard (Minnesota Molecular); Ln3-Plate \#22 extract with saturated $\mathrm{CaCO}_{3}$ solution; Ln4-Plate \#22 extract with $\mathrm{CaCO}_{3}$ solution diluted 1/2; Ln5-Plate \#22 extract with $\mathrm{CaCO}_{3}$ solution diluted 1/4; Ln6-Plate \#22 extract with $\mathrm{CaCO}_{3}$ solution diluted $10^{-1}$; $\mathrm{Ln} 7$-Plate \#22 extract with $\mathrm{CaCO}_{3}$ solution diluted $10^{-2}$; Ln8-Plate \#22 extract with $\mathrm{CaCO}_{3}$ solution diluted $10^{-3}$; Ln9-Plate \#22 extract with $\mathrm{CaCO}_{3}$ solution diluted $10^{-4}$; Ln10-Plate \#22 extract with no added calcium carbonate. The size of PCR products was between $750 \mathrm{bp}$ and $1000 \mathrm{bp}$ by comparison to the Hi-Lo size standard. 
Figure 37. Effect of the addition of PVPP during extraction on the successful amplification of $16 \mathrm{~S}$ rDNA from cave sediments.

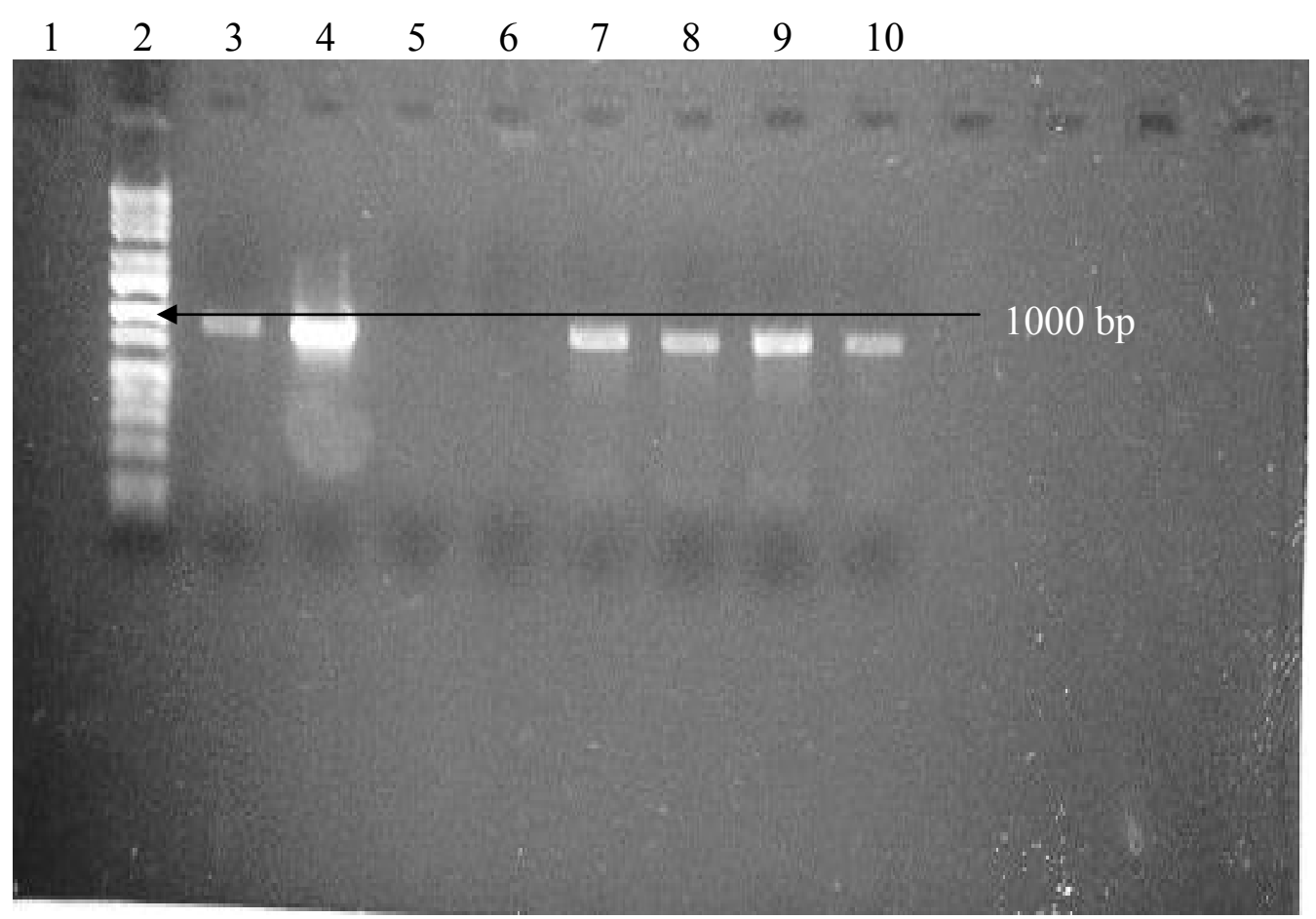

Legend: Ln1-Blank; Ln2-Hi-Lo standard (Minnesota Molecular); Ln3-Cocktail with no template added; Ln4-E. coli extracted by SDS method (Zhou et al. 1996); Ln5-Belt 2 extracted by SDS method; Ln6-Belt 2 extracted by BIO101 method without the addition of PVPP; Ln7-Belt 2 extracted by BIO101 method with PVPP; Ln8-E. coli extracted by BIO101 method with PVPP; Ln9-Belt 2 extracted with PVPP and additional GTC rinse; Ln10-E. coli extracted by BIO101 method with PVPP and additional GTC rinse. 
from all tested extraction methods, in spite of a nearly zero absorbance reading ( 0.0006 at $260 \mathrm{~nm}$ ) for the sample with PVPP treatment alone, diluted 1/30 in 1XTNE buffer. The Belt 2 sample extracted without any additional treatment produced no band on a $1 \%$ agarose by gel electrophoresis. Extracts from the Belt 2 sample by $(0.500 \mathrm{gm}, \mathrm{BIO} 101$ protocol) were successfully amplified (using $1 \mu \mathrm{l}$ of extract) only after the addition of PVPP. An additional 5.5 M GTC rinse improvement over the addition of PVPP alone.

When $0.500 \mathrm{gm}$ of three cave sediments and one surface sediment were extracted by the BIO101 protocol with and without the addition of PVPP, the purity of all samples improved with the addition of 0.050 gm of PVPP, measured by the ratio of A230 nm/A260 nm. Purity as measured by A260 nm/A280 nm absorbance value ratios for the same samples did not improve with the addition of PVPP (Table 9). In other experiments, PVPP was shown to decrease yields of DNA which could influence the A260/A230 ratio. The effects of PVPP and an additional rinse with 5.5 M GTC was evaluated again, using Proteus mirabilis and sediments ( $0.500 \mathrm{gm})$ from two cave sites. The extracts obtained with the additional GTC rinse appear as lighter smears on a $1 \%$ agarose gel when compared to those extracted with only PVPP added (Figure 38). This could be due to a reduction of humic acids but absorbance values were not measured. Again, the addition of a 5.5 M GTC rinse had no effect on the success of amplification from the samples evaluated. All samples were amplified both with and without the additional rinse (Figure 39). Also, the addition of 10mM EGTA to PCR cocktails had no effect on successful PCR (Figure 40).

DNA extract from Belt 2 sample was used to evaluate the effects of template dilution on successful PCR amplification. Five $\mu 1$ of extract or serially diluted extract was used for the amplification. Products from the PCR amplification were visualized on a 1\% 
Table 9. Calculated absorbance ratio values with and without the addition of PVPP in the extraction procedure.

\section{CALCULATED ABSORBANCE RATIOS}

\begin{tabular}{|lc|c|c|c|}
\hline & \multicolumn{2}{c|}{ W/O PVPP } & \multicolumn{2}{c|}{ WITH PVPP } \\
\hline & A260/A280 & A260/A230 & A260/A280 & A260/A230 \\
\hline & & & & \\
S2 Cave & 1.23 & 0.25 & 1.17 & 0.59 \\
S3 Cave & 1.13 & 0.32 & 1.20 & 0.60 \\
Pen 1 Cave & 1.16 & 0.35 & 1.07 & 0.56 \\
Sinking Ck & 1.31 & 0.47 & 1.14 & 0.65 \\
& & & & \\
\hline
\end{tabular}

Legend: The first two columns show calculated absorbance ratios for three cave samples and one surface sample extracted by BIO101 method without the addition of PVPP to the lysis buffer. The second two columns are calculated ratios of absorbance of the same samples extracted by the same protocol with the addition of $0.050 \mathrm{gm}$ of acid-washed PVPP to the lysis buffer. The A260/A280 ratio did not improve and in some cases was lower due to decreased yields of DNA when PVPP was used (results not shown). 
Figure 38. Effect of 5.5M GTC rinse on DNA extracts from cave sediments.

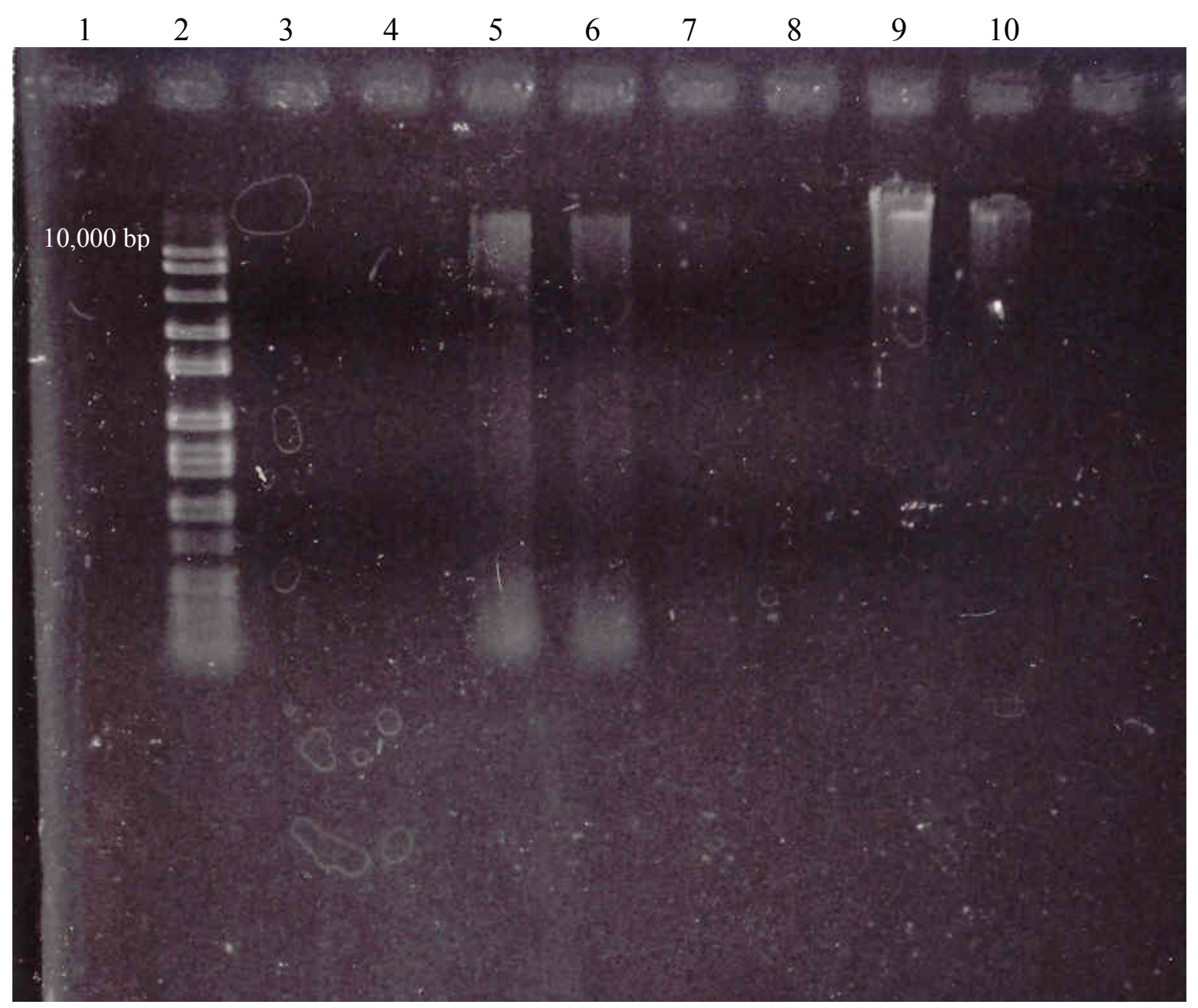

Legend: Twelve $\mu$ of extract on $1 \%$ agarose gel. Samples extracted by a modified BIO101 FastSpin DNA kit for Soil. Fifty mg of acid-washed PVPP was added to all tubes. In addition, each sample was run in duplicate with one replicate receiving an extra rinse with 5.5M GTC. Ln1-Blank; Ln2-Hi-Lo Standard (Minnesota Molecular); Ln3-No sample extraction; Ln4-No sample extraction with GTC rinse; Ln5-Belt 1; Ln6-Belt 1 with GTC rinse; Ln7-Pen 1; Ln8-Pen 1 with GTC rinse; Ln9-Proteus mirabilis; Ln10Proteus mirabilis with GTC rinse. 
Figure 39. PCR amplification products from extracts produced with and without additional GTC rinse.

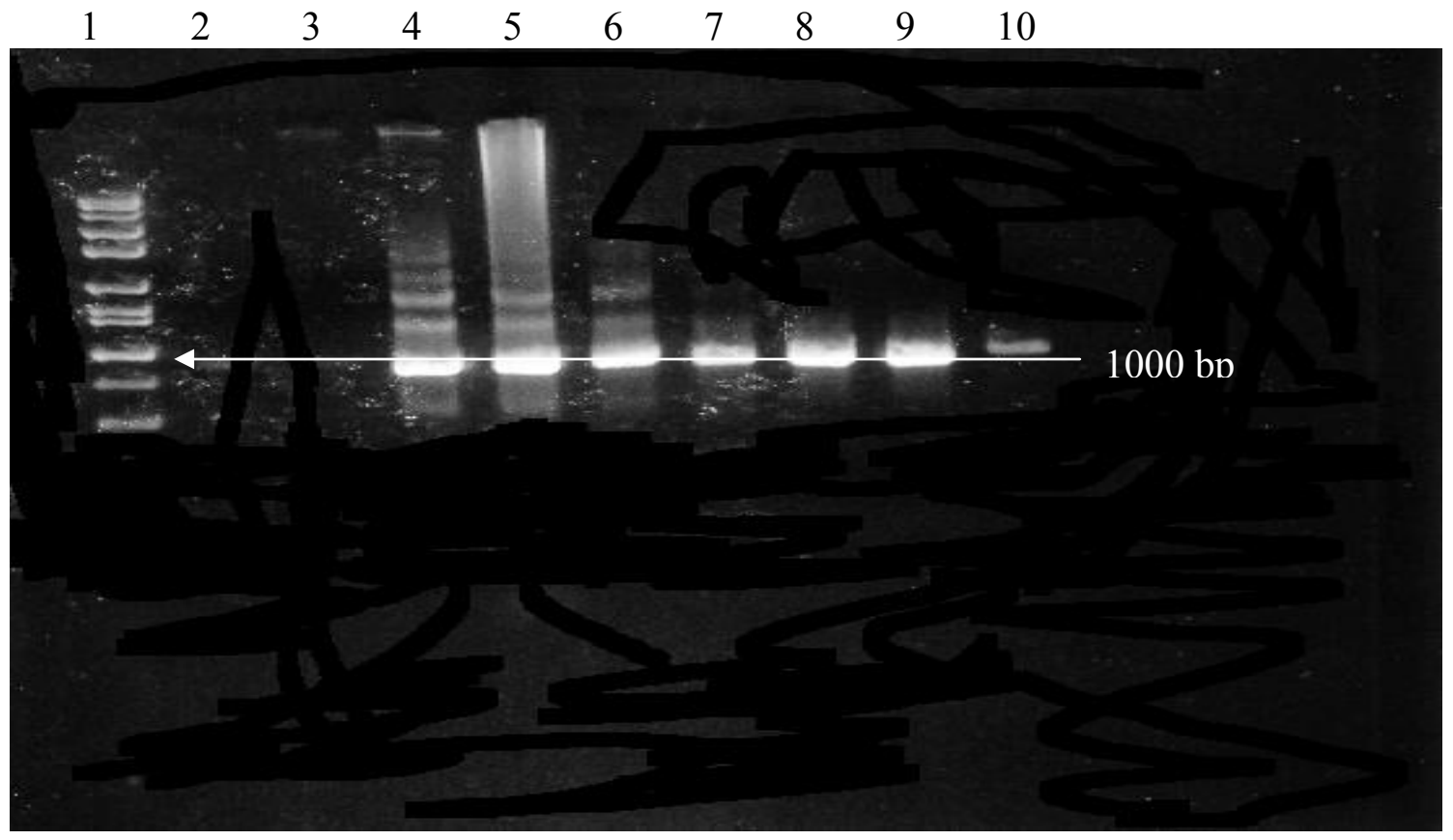

Legend: Samples extracted with $50 \mathrm{mg}$ PVPP in lysis buffer, with and without an additional 5.5M GTC rinse. Samples are without the addition of EGTA to the PCR cocktail. Ln1-Hi-Lo Standard (Minnesota Molecular); Ln2-No sample extraction; Ln3-No sample extraction with GTC rinse; Ln4-Belt 1; Ln5-Belt 1 with GTC rinse; Ln6-Pen 1; Ln7-Pen 1 with GTC rinse; Ln8-Proteus mirabilis; Ln9-Proteus mirabilis with GTC rinse; Ln10-Cocktail with no added template. 
Figure 40. Effect of 10mM EGTA on successful amplication of 16S rDNA from cave sediments.

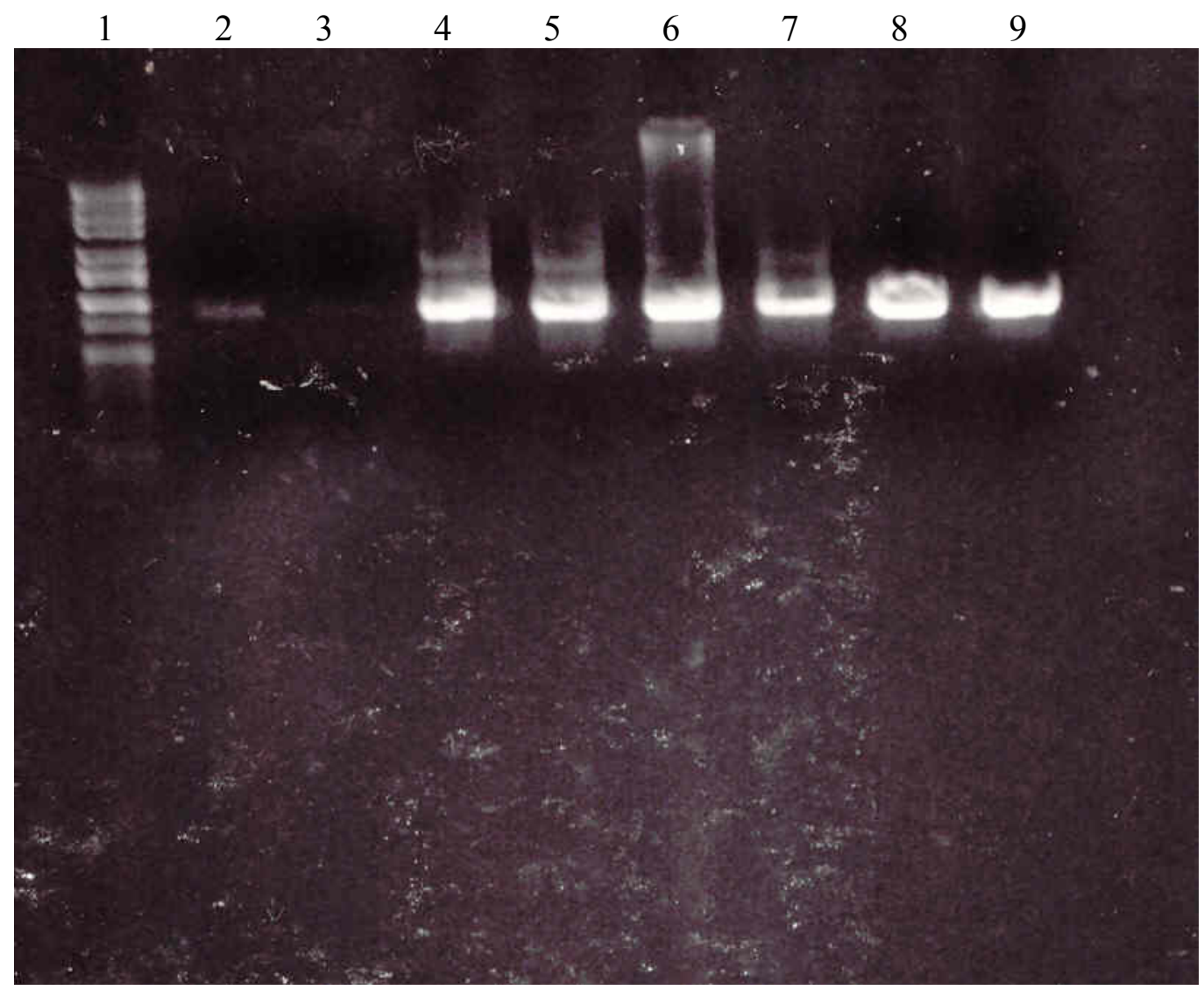

Legend: Twenty $\mu$ l of PCR product on $1 \%$ low-melt agarose gel. All samples were extracted with $50 \mathrm{mg}$ PVPP in lysis buffer by BIO101 method, with and without an additional 5.5M GTC wash. All samples had a final concentration of $10 \mathrm{mM}$ of EGTA in the PCR cocktail. Ln1-Hi-Lo Standard (Minnesota Molecular); Ln2-Cocktail with no template added; Ln3-No sample extraction with GTC rinse; Ln4-Belt 1; Ln5-Belt 1 with GTC rinse; Ln6-Pen 1; Ln7-Pen 1 with GTC rinse; Ln8-Proteus mirabilis; Ln9-Proteus mirabilis with GTC rinse. All products were between $750 \mathrm{bp}$ and $1000 \mathrm{bp}$ in size according to corresponding bands in the size standard. 
agarose gel and the presence of an $891 \mathrm{bp}$ band was observed as a positive result. PCR amplification of 16S rDNA from Belt 2 sediment was successful only after dilutions of the template by $10^{-3}$ (Figure 41 ). This experiment was repeated several times with dilutions from $10^{-2}$ to $10^{-3}$ required to produce the desired PCR product. In addition to purification to reduce calcium and other inhibitors, dilution of extracts to

$1 / 100$ or $1 / 1000$ was necessary for amplification of in-situ extracted DNA. rTth polymerase was used instead of Taq polymerase due to its decreased sensitivity to bivalent ion concentrations in PCR (Al-Soud and Radstrom 1998). Either diluted extracts of total DNA or undiluted extracts of plate cultured cell extractions were used for the remaining experiments.

\section{PURIFICATION OF 16S}

Unpurified PCR products were not acceptable for analysis by spectrophotometry due to the influence of PCR cocktail components. Since PCR product must be purified and concentrated for experiments using spectrophotometry and reassociation rates, several methods of purification were evaluated for their effects on absorbance readings. Both a commercial strain of E. coli and a lab cultured, BIO101 extracted E. coli were used to compare two methods of PCR purification. While comparison of the Microcon and Wizard purified samples by gel electrophoresis showed no difference between the two methods (Figure 42), comparison by spectrophotometry showed that the method of purification influenced both purity and concentration of the nucleic acids. PCR products measured before any purification gave readings at $230 \mathrm{~nm}$ and $260 \mathrm{~nm}$ that were only slightly higher than those of the no template added PCR cocktail (Table 10). Neither method produced very pure samples by A230/A260 readings. Interestingly, the 
Figure 41 Effect of template dilution on successful PCR amplification from cave sediment extracts.

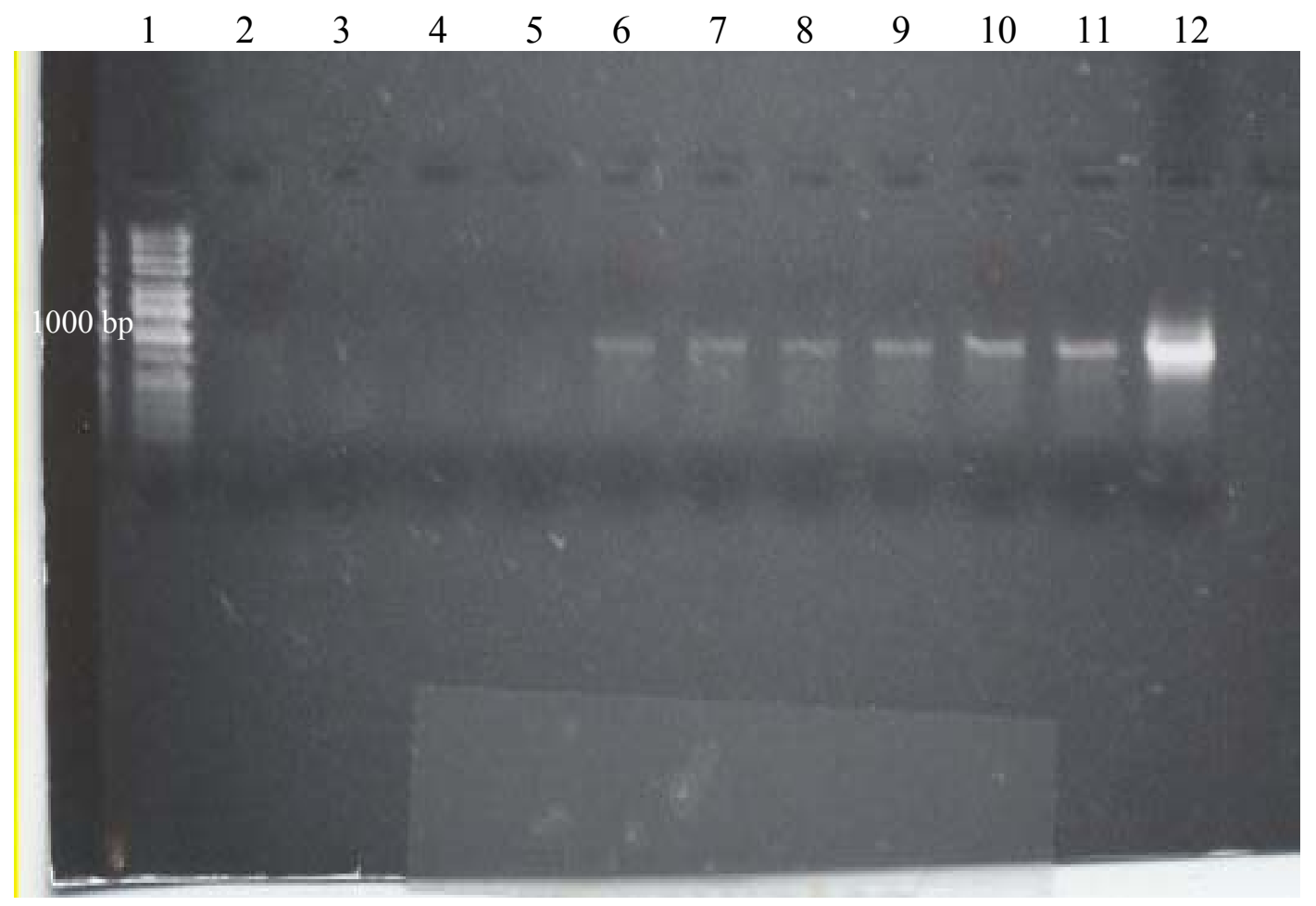

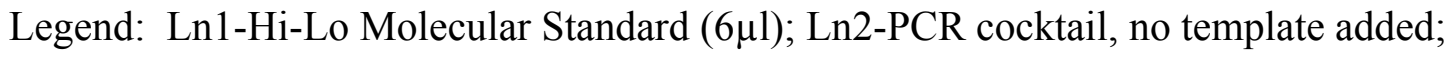
Ln3-Belt Cave sample (Belt 2) diluted 1/2; Ln4-Belt Cave sample diluted 1/10; Ln5-Belt Cave sample diluted 10 ${ }^{-2}$; Ln6-Belt Cave sample diluted 10 ${ }^{-3}$; Ln7-Belt Cave diluted 10-4; Ln8-Belt Cave sample diluted 10-5; Ln9-Belt Cave sample diluted 10-6; Ln10-Belt Cave sample diluted $10^{-7}$; Ln11-Belt Cave sample diluted $10^{-8}$; Ln12-E. coli alone. 
Figure 42. Gel electrophoresis of unpurified and purified 16S amplicons from commercial and lab extracted E. coli samples.

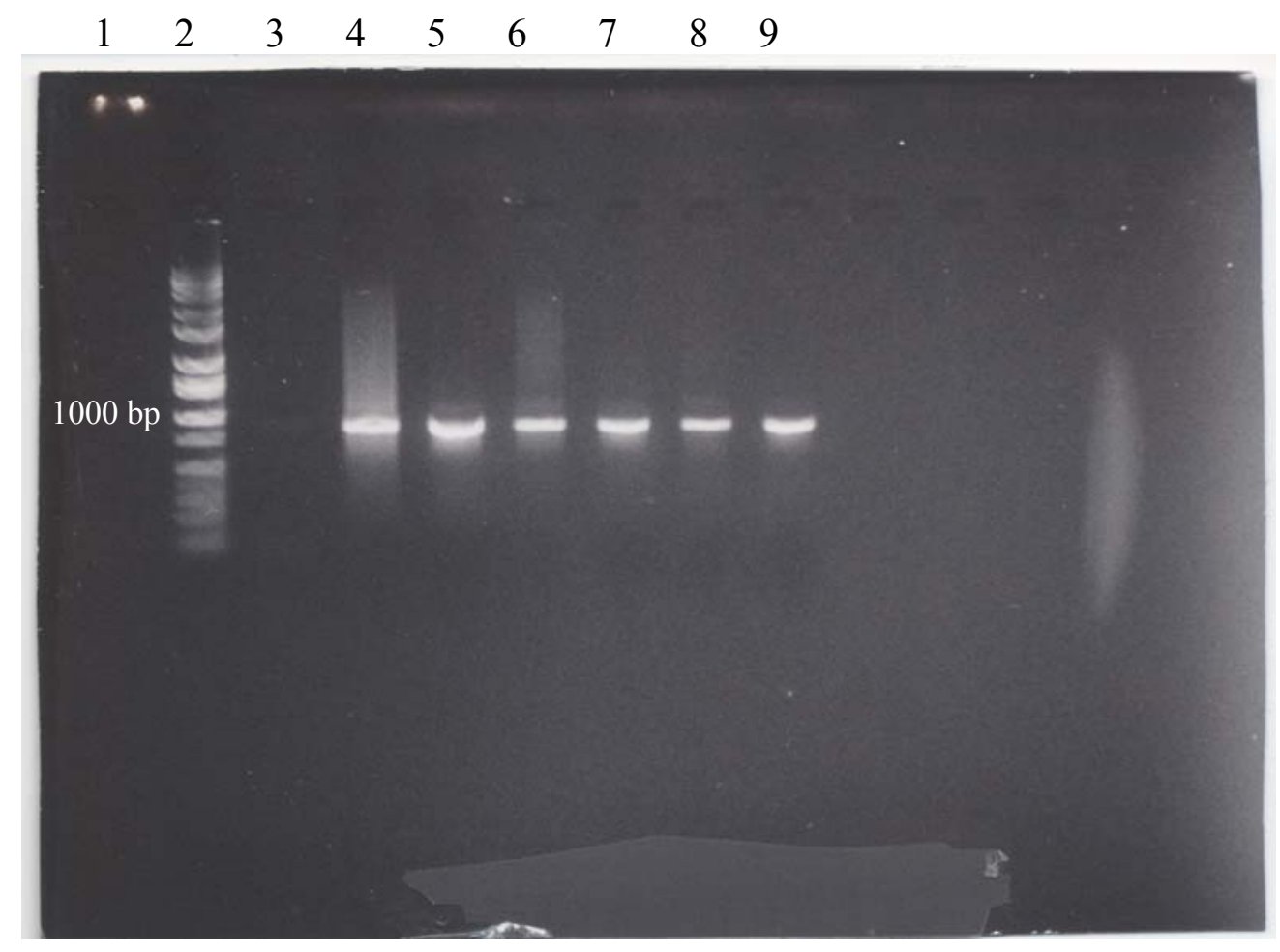

Legend: Ten microliters of sample were electrophoresed on 1\% agarose gel. Samples were untreated, purified by column (Wizard PCR Prep), or by centrifugal filtration (Microcon YM-100). Ln 1-Blank; Ln 2- Hi-Lo Standard (8 $\mu 1$, Minnesota Molecular); Ln 3-Cocktail, no purification; Ln 4-Sigma E. coli, no purification; Ln 5-Lab extracted E. coli, no purification, Ln 6-Sigma E. coli, Wizard purified; Ln 7-Lab extracted E. coli, Wizard purified; Ln 8-Sigma E. coli Microcon purified; Ln 9-Lab extracted E. coli, Microcon purified. 
Table 10. Absorbance values for $16 \mathrm{~S}$ rDNA from a commercially prepared extract and a BIO101 extracted lab strain of E. coli before and after purification diluted $1 / 30$ in 1XTNE.

\begin{tabular}{|l|r|r|r|r|}
\hline \multicolumn{1}{|c|}{ SAMPLE } & $230 \mathrm{~nm}$ & $260 \mathrm{~nm}$ & $280 \mathrm{~nm}$ & $325 \mathrm{~nm}$ \\
\hline 1XTNE & -0.0003 & 0.0001 & 0.0000 & -0.0003 \\
\hline Sigma PCR & 0.5348 & 1.2784 & 0.6001 & 0.0015 \\
\hline BIO101 PCR & 0.5419 & 1.2935 & 0.6053 & 0.0008 \\
\hline Sigma Wizard & 0.6362 & 0.0136 & 0.0063 & 0.0008 \\
\hline BIO101 Wizard & 0.5088 & 0.0181 & 0.0099 & 0.0026 \\
\hline Sigma Microcon & -0.0117 & 0.0064 & 0.0027 & 0.0007 \\
\hline BIO101 Microcon & -0.0113 & 0.0095 & 0.0044 & 0.0002 \\
\hline PCR Cocktail & & & & \\
\hline & 0.5119 & 1.2246 & 0.5748 & 0.0012 \\
\hline EZ-Sigma Filtrate & 0.0170 & 0.0791 & 0.0370 & 0.0003 \\
\hline EZ-BIO101 Filtrate & 0.0191 & 0.0725 & 0.0360 & 0.0030 \\
\hline
\end{tabular}

Legend: PCR samples are directly from amplification reactions. The PCR cocktail sample has no added DNA template. Those samples labeled EZ-Filtrate were taken after filtration through the Microcon EZ Purification filters for removal of the polymerase enzyme but before filtration through the Microcon YM-100 filter. Other samples, Wizard and Microcon samples are from the final purified products by those methods. 
Microcon purified samples had negative absorbance readings $230 \mathrm{~nm}$ compared to Wizard purified samples which still had absorbance values near the same level as unpurified PCR product. Reassociation rates were also affected by the method of purification used. Whether amplicons were purified by Wizard PCR Prep or by Microcon centrifugal filtration, there was a loss of DNA as observed by UV illumination after electrophoresis on $1 \%$ agarose gel spiked with ethidium bromide. The loss was also measurable by spectrophotometry. Using A260 values and calculated ratios for A260/A230 and A260/A280 showed much lower yields when using Microcon centrifugal filtration for purification compared to those purified using the Wizard PCR prep method. Although absorbance values of both the Sigma and BIO101 16S amplicons purified by Microcon were lower ( 0.0338 and .0360 respectively) than yields from the Wizard purification, the ratios for A260/A230 and A260/A280 were closer to the acceptable range when compared to those purified by the Wizard method.

A comparison of the Wizard and Microcon purified samples by reassociation at $25^{\circ} \mathrm{C}$ also showed differences between the two purification methods. After baseline absorbance readings at room temperature, $40 \mu 1$ of both Wizard and Microcon purified samples were denatured in 0.1XSSC. Microcon samples were 83\% (Sigma) and 91\% BIO101) denatured after 4 minutes at $95^{\circ} \mathrm{C}$ according to calculated theoretical A260 readings. Wizard purified samples were 73\% (Sigma) and 75\% (BIO101) denatured after 4 minutes at $95^{\circ} \mathrm{C}$. The Sigma prepared extract produced absorbance values of 0.3503 at $25^{\circ} \mathrm{C}$ increasing to 0.3664 after stabilization at $95^{\circ} \mathrm{C}$. The BIO101 extracted lab strain had an absorbance of .3953 at $260 \mathrm{~nm}$ at $25^{\circ} \mathrm{C}$ and reached a high reading of 0.4212 at $95^{\circ} \mathrm{C}$. Both strains of E. coli purified by Wizard columns were $50 \%$ reassociated in less than 30 seconds, while the reassociation rates of the samples purified by Microcon 
YM-100 were much slower (greater than 16 minutes). Ribosomal DNA amplified from both E. coli strains had consistent reassociation rates when reassociation was measured at the same buffer concentration (IXSSC) using a split sample of DNA dilutions for the analyses. When samples were standardized to absorbance readings of approximately 1.0, or $50 \mathrm{mg} / \mathrm{ml}$, at $25^{\circ} \mathrm{C}$, both $E$. coli strains were $50 \%$ reassociated between 1.3 and 1.5 minutes each time.

\section{ANALYSES OF DIVERSITY AND COMMUNITY STRUCTURE}

\section{CELL NUMBERS}

Colonies were counted from R2A plates incubated aerobically at $4^{\circ} \mathrm{C}$ for 16 days in a humid environment (Figure 43). All plate counts represented $0.1 \%$ or less $(0.1$ $0.00001 \%$ ) of the cells counted directly using DAPI stain and epifluorescent microscopy (Table 11). Cells were not cultured from the Belt 2 sample as the site was inaccessible due to high water. While no quantitative distinction of colony types was made, nor any species identified, it was observed that the majority of colonies from the cave samples were white with very few pale yellow or peach colonies (Figure 44). This agreed with previous studies in Mammoth Cave (Rusterholtz and Mallory 1995) which reported colonies of bacteria isolated from the cave sediments were mostly small, circular and white. This is likely an adaptation to the cave environment. The surface samples in this study contained mainly yellow to orange colonies with some purple and some white (Figure 45). 
Figure 43. Colonies counted on R2A agar after 16 days incubated at $4^{\circ} \mathrm{C}$.

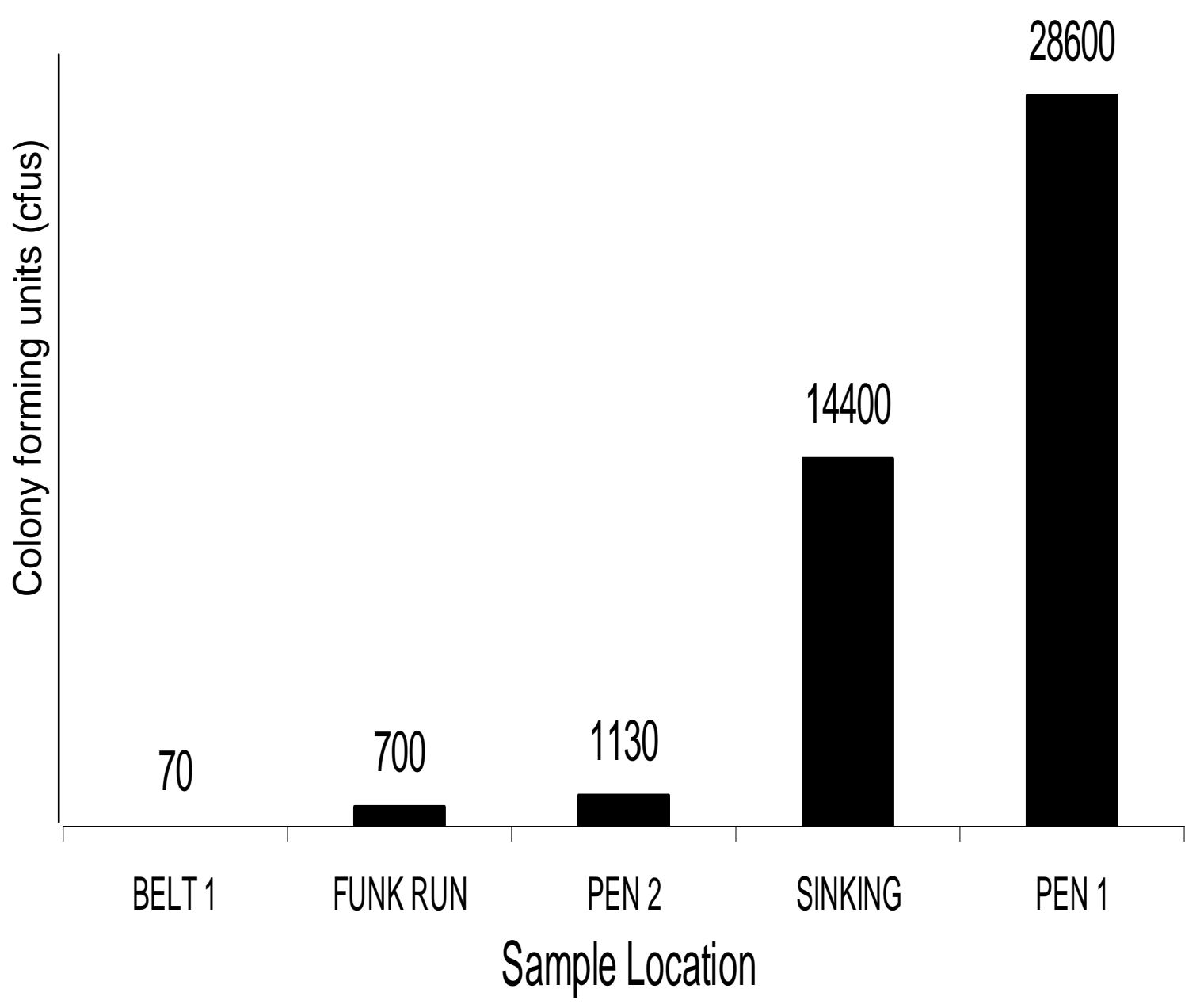

Legend: Comparison of culturable numbers of bacteria after 16 days incubation at $4^{\circ} \mathrm{C}$ on R2A agar plates per gram of sediment (cfus/gram wet wt.). Samples were collected and plated on 11-22-02. Results were calculated from plates with 20-300 colonies. 
Table 11. Comparison of direct cell counts and plate counts on R2A.

\begin{tabular}{|l|c|c|c|}
\hline \multicolumn{1}{|c|}{ SAMPLE } & R2A COUNTS & DIRECT COUNTS & $\begin{array}{c}\% \\
\text { CULTURABLE }\end{array}$ \\
\hline Sinking Creek & $1.44 \times 10^{4}$ & $4.97 \times 10^{8}$ & 0.003 \\
\hline Funks Run & $7.00 \times 10^{2}$ & $8.15 \times 10^{8}$ & 0.0001 \\
\hline Pen 1 & $2.86 \times 10^{4}$ & $2.52 \times 10^{7}$ & 0.1135 \\
\hline Pen 2 & $1.13 \times 10^{3}$ & $1.34 \times 10^{9}$ & 0.0001 \\
\hline Belt 1 & $7.00 \times 10^{1}$ & $8.44 \times 10^{8}$ & 0.00001 \\
\hline Belt 2 & $\mathrm{ND}$ & $3.93 \times 10^{8}$ & ND \\
\hline
\end{tabular}

Legend: Column A shows the number of colony forming units (cfus) on R2A plates at $4^{\circ} \mathrm{C}$ after 16 days incubation. In Column B, cells counted using epifluorescent microscopy and DAPI stain. Both plate counts and direct cell counts are reported per gram of sediment. Belt 2 site did not have a plate count as the site was inaccessible due to high water at the time of sample collection. Therefore, the $\%$ culturable could not be calculated. 
Figure 44. Photo of colonies cultured from surface sediment on R2A plates after 16 days at $4^{\circ} \mathrm{C}$.

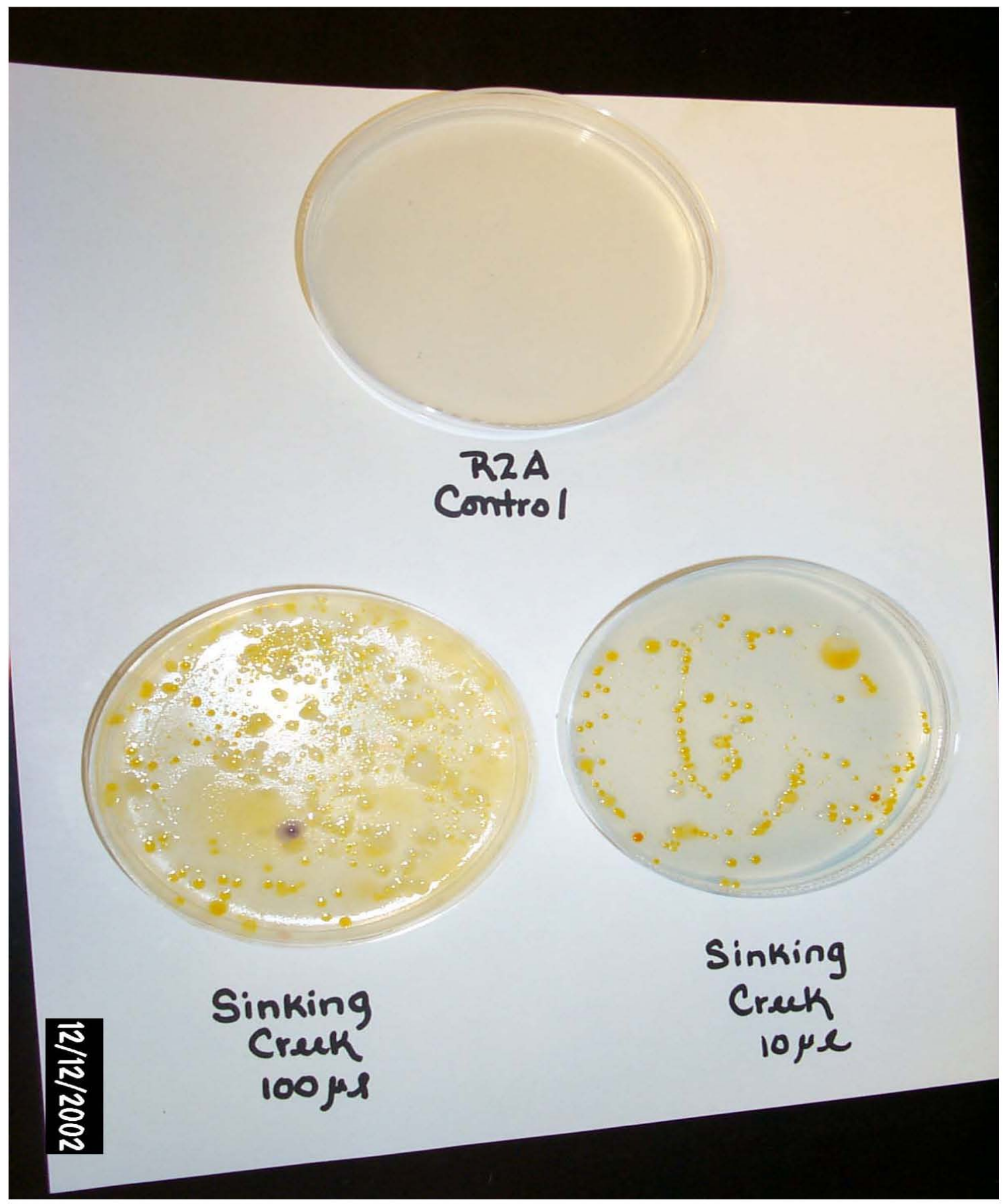

Legend: Photo of cultured community from the surface site of Sinking Creek on R2A agar at $4^{\circ} \mathrm{C}$. Samples were plated 16 days prior. The majority of colonies were pigmented. 
Figure 45. Photo of colonies cultured from cave sediments on R2A plates after 16 days at $4^{\circ} \mathrm{C}$.

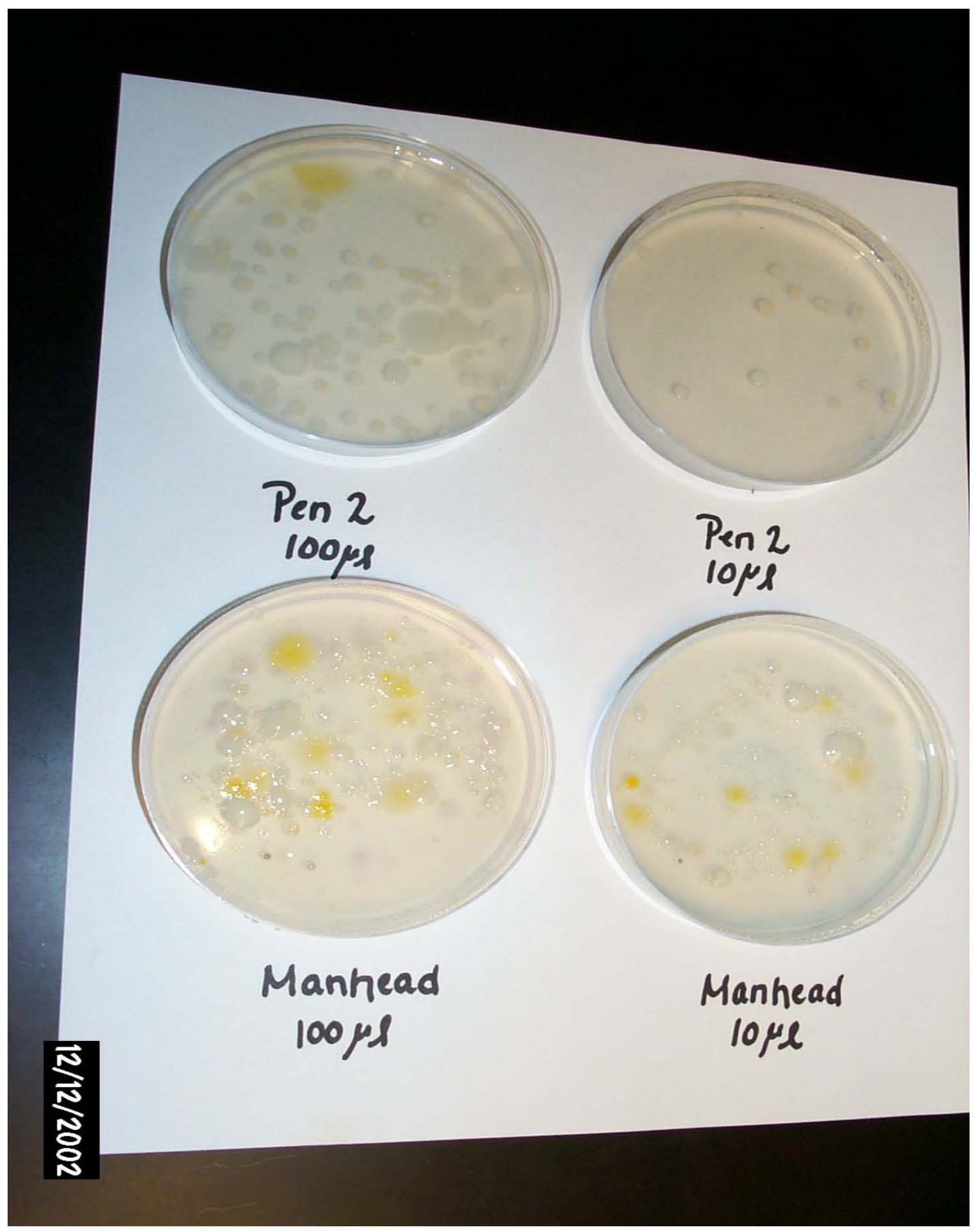

Legend: Photo of colonies cultured from a Penitentiary Cave sediment after incubation for 16 days at $4{ }^{\circ} \mathrm{C}$. The majority of colonies were non-pigmented or light colored. 
Using Pearson's simple linear correlation, plate counts were highly correlated with average particle size of the sediment samples $(\mathrm{r}=0.8312)$. Although not as highly correlated as numbers of colonies counted on R2A agar, simple linear correlation revealed an inverse relationship between particle size of the sediment and cell numbers by fluorescent microscopy and DAPI stain $(\mathrm{r}=-0.5650)$.

\section{ARDRA ANALYSES}

After PCR amplification, appropriate size bands were observed for all cultured community samples on $1 \%$ agarose. A cocktail sample with no template added was run with each set of PCR samples and all were negative. However, the Pen 1 sample produced a band slightly larger than the expected $0.8 \mathrm{~kb}$. Yield and purity of the cultured 16S amplicons were not determined and template was used directly from PCR reactions without purification or concentration. Amplicons from cultured communities were digested without standardization as absorbance was not measured.

None of the cultured communities digested with HhaI, BanI, and RsaI enzymes together exhibited a great number of bands $(n \leq 4)$. However, it was possible to observe differences between communities both by visual and calculated methods. Similarity of community structure was conducted using the restriction pattern (Figure 46) and Sorensen's coefficient of similarity (Cs) (Table 12). Although not visually proportional, the two surface sites (Sinking Creek and Funks Run) produced identical band patterns by the calculated coefficient of similarity $(\mathrm{Cs}=1.0)$ as did the two samples from Penitentiary Cave $(\mathrm{Cs}=1.0)$ when compared to each other . However, the cave sites differed from each other $(\mathrm{Cs}=0.86)$. In addition, both Penitentiary Cave and Belt Cave signatures differed from surface community restriction patterns with Cs values of 0.75 and 0.86 
Figure 46. ARDRA signatures of cultured community DNA from cave and surface samples.

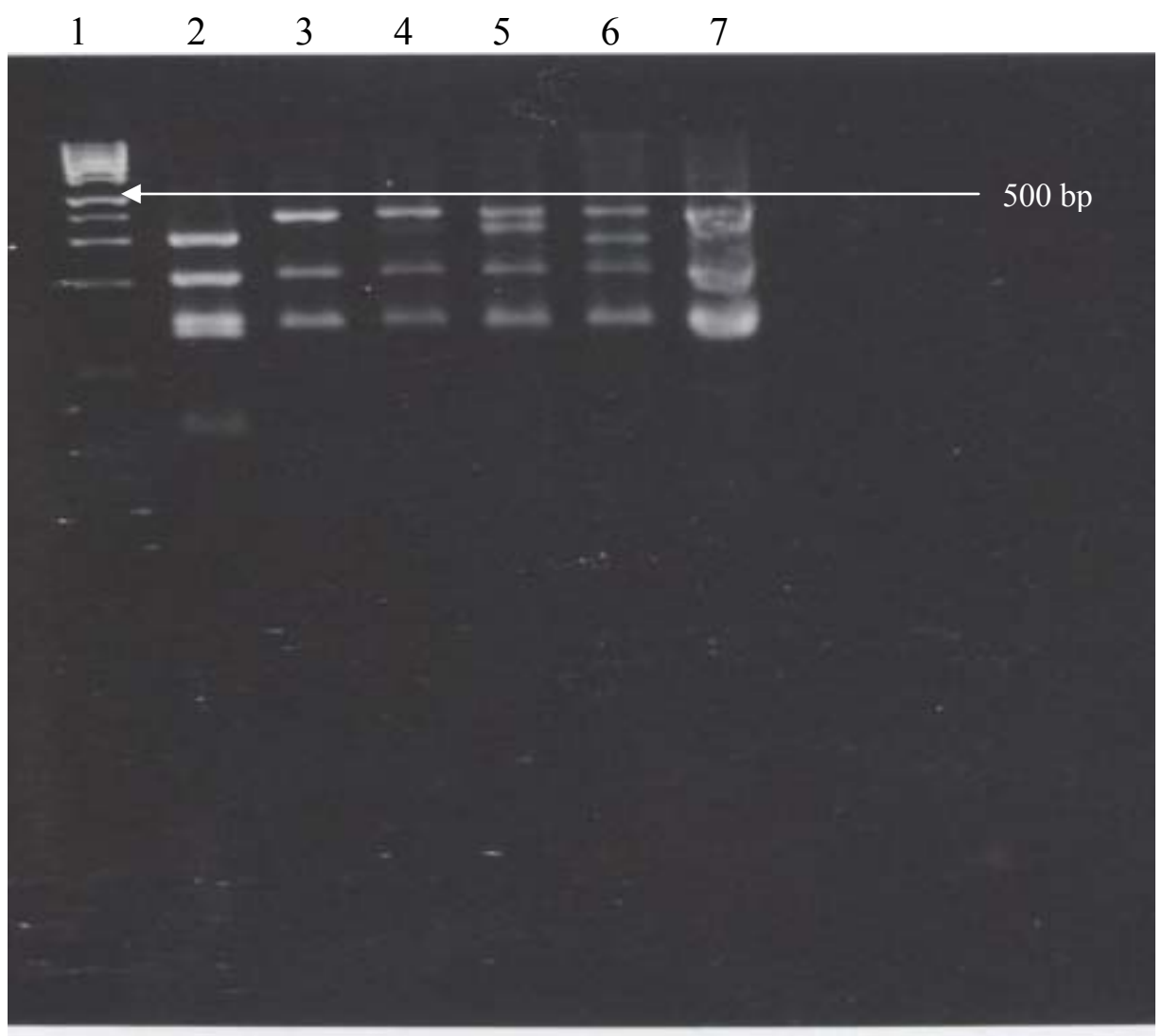

Legend: Restriction digests $(20 \mu \mathrm{l})$ of cultured community $16 \mathrm{~S}$ rDNA with HhaI, RsaI, and BanI enzymes on 3\% agarose. Ln 1-Hi-Lo Standard; Ln2-E. coli; Ln3-Belt 1 (C); Ln 4-Sinking Creek (S); Ln 5-Funks Run (S); Ln 6-Pen 2 (C); Ln 7-Pen 1 (C). Bands in E. coli pattern correspond to sizes of $315,216,150$, and 136, and 60 basepairs from top to bottom. 
Table 12. Calculated correlation of similarity (Cs) values for ARDRA signatures of cultured community DNA of cave and surface samples.

\begin{tabular}{|l|r|r|r|r|r|}
\hline & Belt 1 & Pen 1 & Pen 2 & Sinking & Funks \\
\hline Belt 1 & 1 & 0.86 & 0.86 & 0.86 & 0.86 \\
\hline & & & & & \\
Pen 1 & 0.86 & 1 & 1 & 0.75 & 0.75 \\
\hline & & & & & \\
Pen 2 & 0.86 & 1 & 1 & 0.75 & 0.75 \\
\hline & & & & & \\
Sinking & 0.86 & 0.75 & 0.75 & 1 & 1 \\
\hline & & & & & \\
\hline Funks & 0.86 & 0.75 & 0.75 & 1 & 1 \\
\hline
\end{tabular}

Legend: These are the calculated Cs values for cultured community ARDRA patterns using the formula $2 \mathrm{j} / \mathrm{A}+\mathrm{B}$ for Sorensen's coefficient of similarity (Sorensen 1948). Cultured community amplicons were digested with HhaI, RsaI, and BanI enzymes. 
respectively.

Three $\mu 1$ of purified and concentrated (Microcon YM-100) 16S amplicons from total community DNA were used to verify presence of nucleic acids before digestion.

Samples stained with ethidium bromide were observed on $1 \%$ agarose and appropriate bands were present for all samples (Figure 47).

Products of pooled and purified amplification reactions yielded from $1.662 \times 10^{3}$ to $3.089 \times 10^{3} \mathrm{mg} / \mathrm{ml}$ measured by absorbance spectrophotometry at $1 / 300$ dilutions in 1XTNE. A260/A230 calculated ratios were 1.5 to 2.2 for all samples except Pen 2, with a value of 2.81 (Table 13). A260/A230 ratios were all above 1.7 except E. coli and the Pen 2 samples which were 1.44 and 1.31 respectively. Although absorbance was measured, total community $16 \mathrm{~S}$ rDNA was not standardized between samples before digestion. Nucleic acid concentrations of the two surface samples were much lower than the other samples.

Digestion of the total community $16 \mathrm{~S}$ amplicons with HhaI, RsaI, and BanI produced a more complex pattern of bands than that seen for the cultured portion of the communities (Figure 48). However, without an imaging program, bands were difficult to distinguish. Cleaning and concentrating the PCR product before digestion did not improve the quality of the restriction pattern using 3\% agarose for separation (Figure 49). Comparing the total community ARDRA patterns, Belt Cave exhibited the lowest pattern complexity and the most faint signature. Pen 2 and Sinking Creek extracts produced identical signatures when digested with HhaI, RsaI, and BanI enzymes. Based on correlation of similarity (Cs) values for total community ARDRA signatures (Table 14), Belt Cave was most different from all other digested samples $(\mathrm{Cs}=0.63)$. The two surface sites were different from each other but still had a calculated Cs value of 0.91 . 
Figure 47. Photograph of total community $16 \mathrm{~S}$ amplicons on $1 \%$ agarose gel.

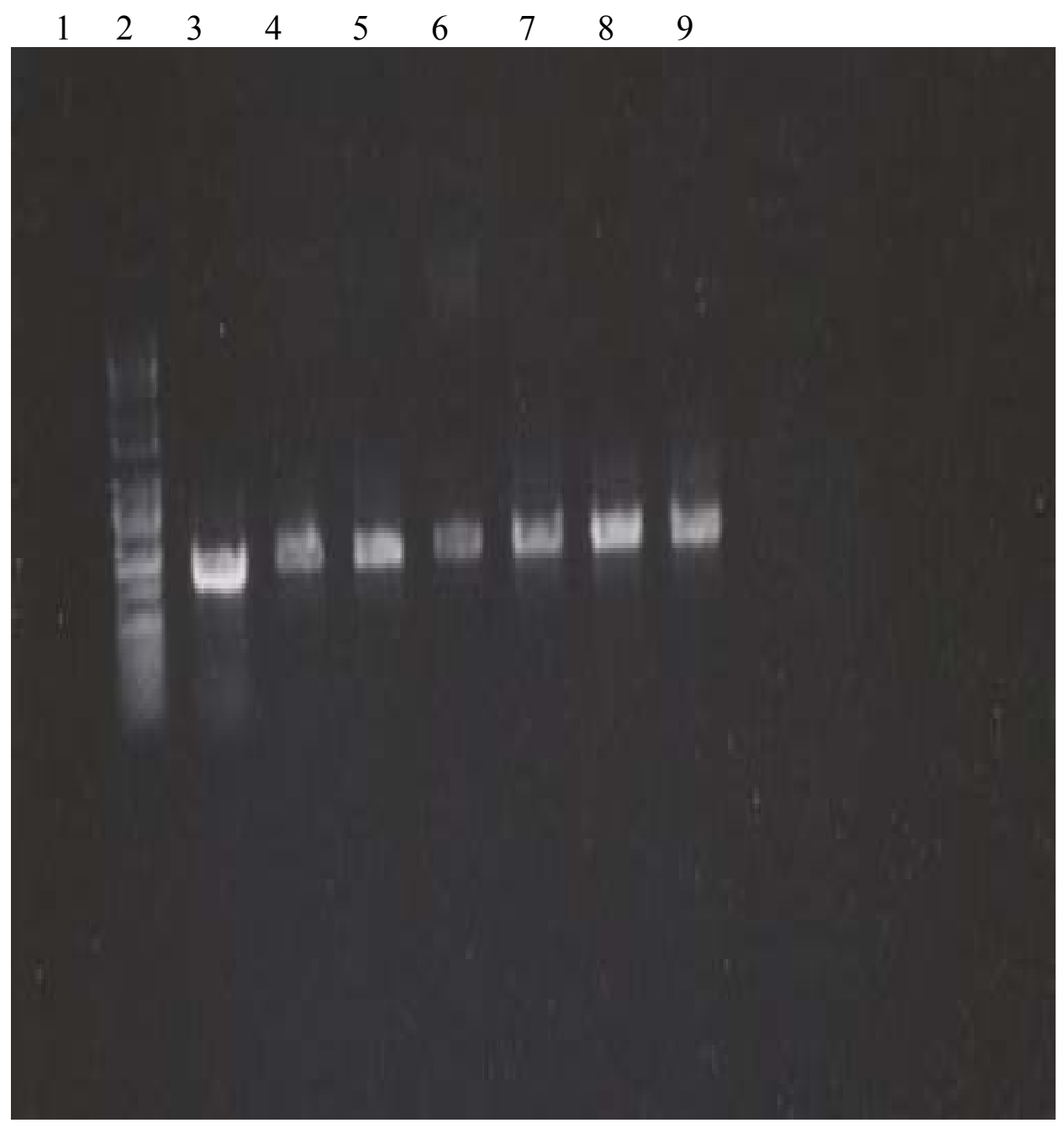

Legend: Three $\mu \mathrm{l}$ of total community $16 \mathrm{~S}$ amplicons - concentrated, purified, and ready for restriction enzyme digestion. Ln 1-Blank; Ln 2-Hi-Lo Standard (Minnesota Molecular); Ln 3-E. coli; Ln 4-Pen 1; Ln 5-Pen 2; Ln 6-Belt 2; Ln 7-Belt 1; Ln 8-Sinking Creek; Ln 9-Funks Run. Size of the PCR products were approximately $1000 \mathrm{bp}$. 
Table 13. Absorbance readings of pooled, cleaned, and concentrated total community amplicons diluted 1/300 in 1XTNE.

\begin{tabular}{|l|r|r|r|r|r|r|r|}
\hline & $230 \mathrm{~nm}$ & $260 \mathrm{~nm}$ & $280 \mathrm{~nm}$ & $325 \mathrm{~nm}$ & $\begin{array}{l}\text { Yield } \\
\text { mg/ml }\end{array}$ & A260/A280 & A260/A230 \\
\hline 1XTNE & 0.0000 & 0.0000 & 0.0001 & 0.0001 & & & \\
\hline E. coli & 0.1365 & 0.2059 & 0.1428 & 0.0130 & 3089 & 1.44 & 1.51 \\
\hline Pen 1 & 0.0541 & 0.1108 & 0.0577 & 0.0032 & 1662 & 1.92 & 2.01 \\
\hline Pen 2 & 0.0513 & 0.1440 & 0.0869 & 0.0181 & 2160 & 1.31 & 2.81 \\
\hline Belt 2 & 0.0622 & 0.1143 & 0.0620 & 0.0092 & 1715 & 1.84 & 1.84 \\
\hline Belt 1 & 0.0769 & 0.1567 & 0.0817 & 0.0087 & 2351 & 1.92 & 2.02 \\
\hline Sinking & 0.0710 & 0.1318 & 0.0765 & 0.0192 & 2027 & 1.75 & 1.86 \\
\hline Funks & 0.0526 & 0.1176 & 0.0636 & 0.0092 & 1764 & 1.85 & 2.24 \\
\hline
\end{tabular}

Legend: The yield and purity of DNA in all products were measured in a BeckmanCoulter DU640 spectrophotometer. Yield was calculated using the formula (Absorbance of 1.0 at $260 \mathrm{~nm}=50 \mathrm{mg} / \mathrm{ml}$ of DNA). Purity was checked by the calculation of A260/A280 and A260/A230. Highly purified DNA should have ratios of 1.8-2.0. Absorbance readings at $325 \mathrm{~nm}$ wavelengths indicates the presence of particulate matter in the sample. 
Figure 48. Photograph of total community ARDRA signatures for cave and surface samples on $4 \%$ agarose gel.

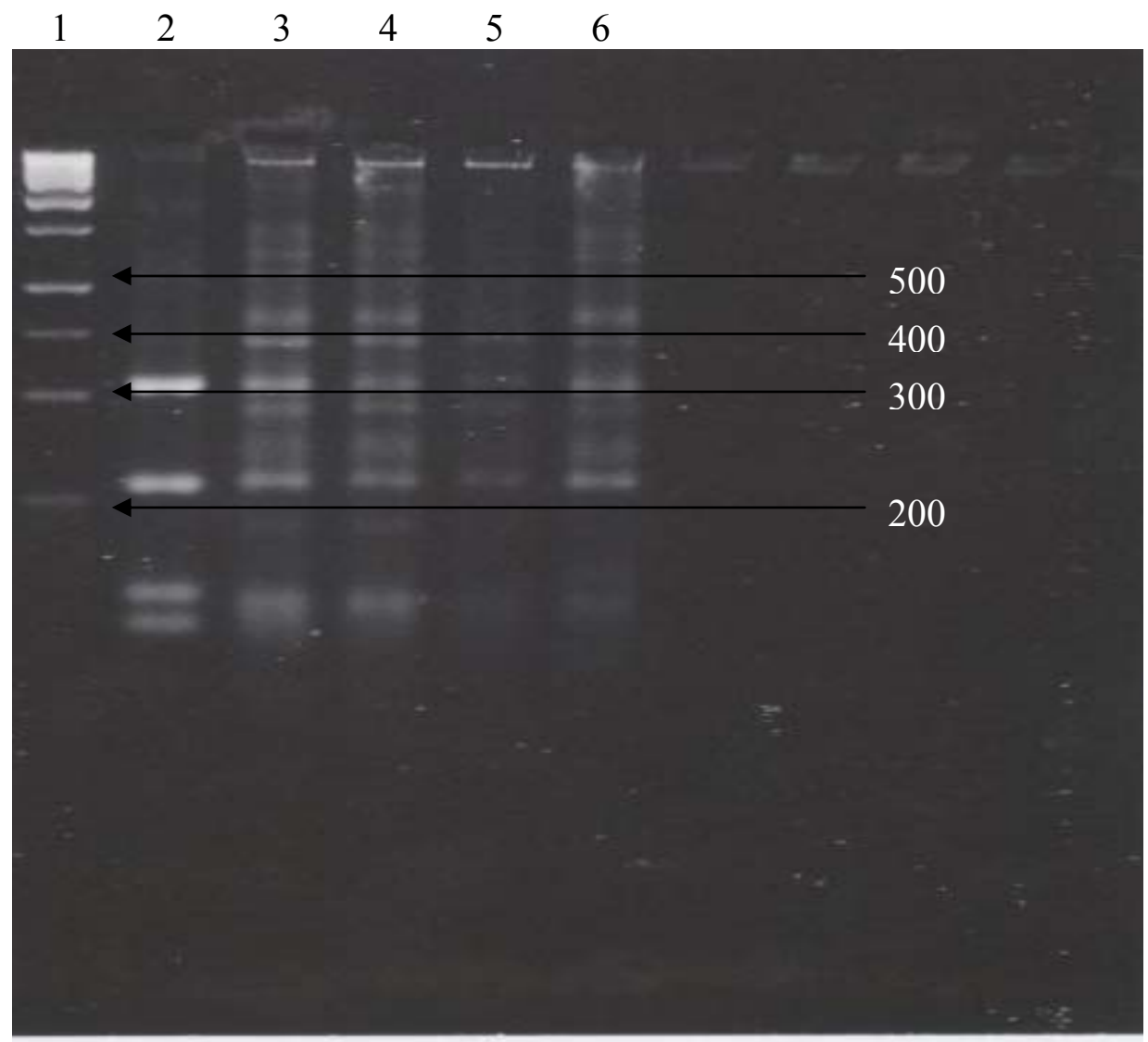

Legend: Total community $16 \mathrm{~S}$ digests on $4 \%$ agarose gel. Digestions were set with $5 \mu 1$ of $E$. coli extract and $32 \mu 1$ of other extracts were used in $40 \mu 1$ reactions. The entire volume of each reaction was electrophoresed for observation. Ln 1-Hi-Lo Standard $(8 \mu \mathrm{l})$ (Minnesota Molecular); Ln 2-E. coli; Ln 3-Sinking Creek; Ln 4-Pen 2; Ln 5-Belt 2; Ln 6-Funks Run. 
Figure 49. Photograph of total community ARDRA signatures using concentrated PCR product.

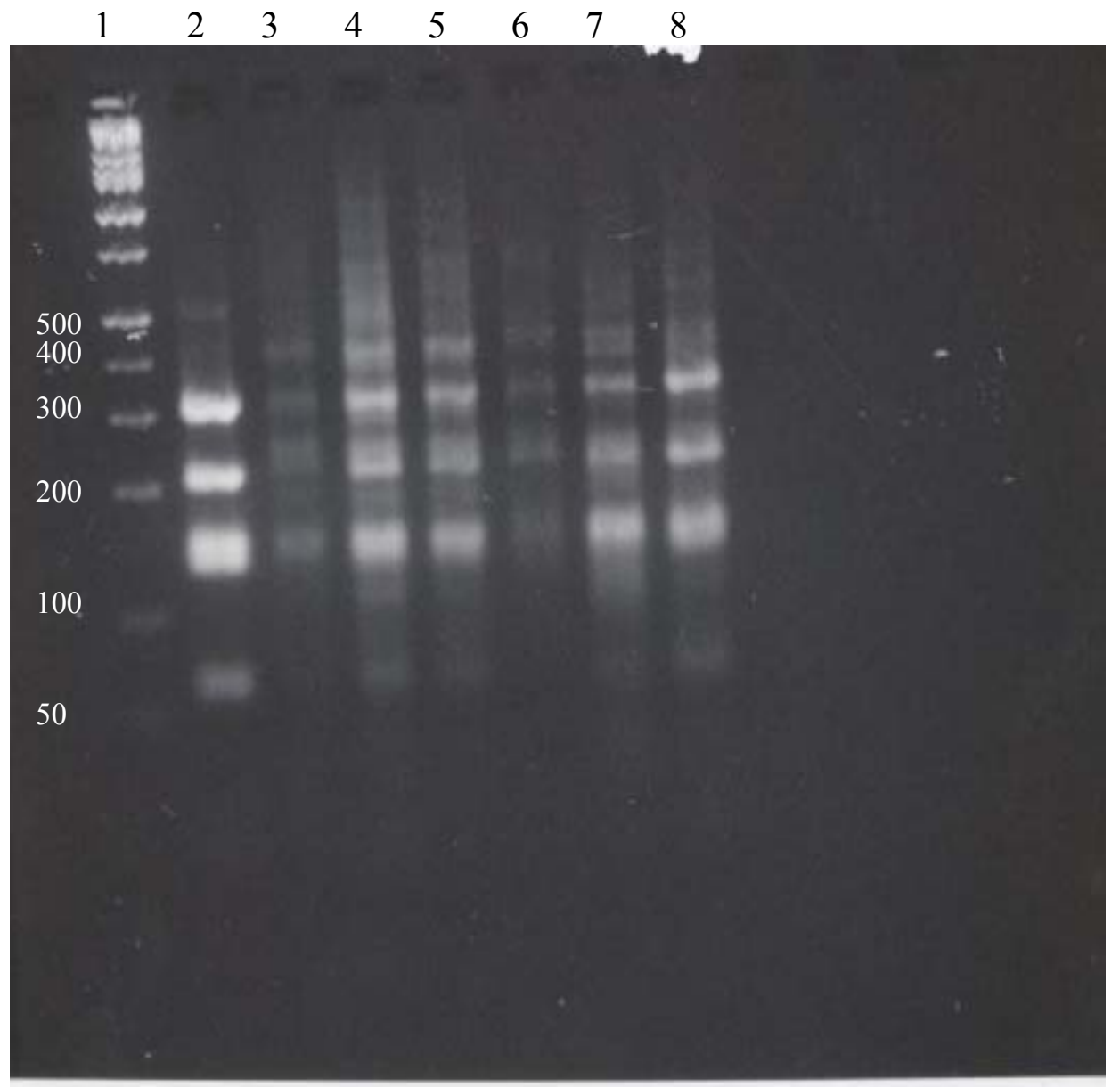

Legend: Forty $\mu$ of total community $16 \mathrm{~S}$ amplicons were concentrated by centrigugal filtration (Microcon YM-100) and digested with HhaI RsaI, and BanI. The entire volume of each digestion was loaded on 3\% agarose gel and visualized by UV illumination after 3 hours at 5V/cm. Ln 1-Blank; Ln 2-Hi-Lo Standard (Minnesota Molecular); Ln 3-E. coli; Ln 4-Belt 1; Ln 5-Belt 2; Ln 6-Sinking Creek; Ln 7-Funks Run; Ln 8-Pen 2; Ln 9Pen 1. 
Table 14. Calculated correlation of similarity (Cs) values for total community ARDRA signatures.

\begin{tabular}{|l|r|r|r|r|}
\hline & Sinking & Pen 2 & Belt 1 & \multicolumn{2}{|c|}{ Funk Run } \\
\hline Sinking & 1 & 1.00 & 0.63 & 0.91 \\
\hline Pen 2 & 1.00 & 1 & 0.63 & 0.91 \\
\hline Belt 1 & 0.63 & 0.63 & 1 & 0.63 \\
\hline Funk Run & 0.91 & 0.91 & 0.63 & 1 \\
\hline
\end{tabular}

Legend: These are the calculated Cs values for total community ARDRA patterns using the formula 2j/A + B for Sorensen's coefficient of similarity (Sorensen 1948). Total direct extracted community amplicons were digested with HhaI, RsaI, and BanI enzymes. 


\section{ANALYSES OF GENETIC COMPLEXITY}

\section{REASSOCIATION}

In initial experiments to determine the accuracy limits of detection for the chosen methods of nucleic acid analyses, a commercial preparation of salmon testes DNA (Sigma Chemical $10 \mathrm{mg} / \mathrm{ml}$ ) was diluted and measured until absorbance readings no longer provided accurate measurements (Table 15). These experiments were carried out due to the difficulty in obtaining large amounts of nucleic acids for molecular analyses. Calculations using the absorbance readings and protocols for nucleic acid detection (Sambrook 1989), were accurate from $24 \mu \mathrm{g}(1 / 125)$ to a $1 / 4000$ dilution $(0.75 \mu \mathrm{g})$ of the $10 \mathrm{mg} / \mathrm{ml}$ sample in 1 XSSC Buffer. The bottom limit was somewhere between $0.75 \mu \mathrm{g}(1 / 4000)$ and $0.375 \mu \mathrm{g}(1 / 8000)$ total DNA in the sample.

However, even within the limits of accuracy, the concentration of DNA and the buffer concentration influenced the rates of DNA reassociation. When concentrations of sheared Salmon testes DNA were lowered from $25 \mu \mathrm{g}$ to $3.125 \mu \mathrm{g}$ in $300 \mu \mathrm{l}$ of the same buffer (1XSSC), reassociation rates at $42^{\circ} \mathrm{C}$ were slowed from 1.7 to 4.5 minutes (Figure 50). Decreasing buffer concentrations from $0.1 \mathrm{X}$ to $10 \mathrm{X}$ standard saline citrate (SSC) Buffer with the same nucleic acid concentration also increased the time for $50 \%$ reannealling. Reassociation of E. coli $16 \mathrm{~S}$ DNA increased from values of 1.1 minutes in 10XSSC Buffer to values as high as 12 minutes in $0.1 \mathrm{XSSC}$ at concentrations of $20 \mu \mathrm{g}$ DNA per $300 / \mu 1$ reaction. At concentrations of $25 \mu \mathrm{g} / 300 \mu 1$ reaction, $50 \%$ of the $16 \mathrm{~S}$ rDNA was reassociated in only 0.7 minutes in $5 \mathrm{XSSC}$ while in $0.1 \mathrm{XSSC}$ DNA was not calculated to be $50 \%$ single stranded until 7.1 minutes.

When total community genomic DNA extracted from Belt Cave $(30 \mu 1)$ was reassociated at $25^{\circ} \mathrm{C}$ in $1 \mathrm{XSSC}$ Buffer along with E. coli $(15 \mu 1)$ as a standard of 
Table 15. Minimal detection of nucleic acids by absorbance spectrophotometry.

MINIMAL DETECTION OF NUCLEIC ACIDS
BY ABSORBANCE SPECTROPHOTOMETRY

\begin{tabular}{|cccccc|}
\hline Dilution & $\mu g D N A / 300 u l$ & A260 & {$[\mathrm{DNA}] \mathrm{mg} / \mathrm{ml}$} & A260/A280 & A260/A230 \\
$1 / 125$ & 24 & 1.7896 & 11.2 & 1.9 & 2.39 \\
$1 / 250$ & 12 & .8103 & 10.1 & 1.9 & 2.44 \\
$1 / 500$ & 6 & .4001 & 10.0 & 1.9 & 2.43 \\
$1 / 1000$ & 3 & .2020 & 10.1 & 1.9 & 2.39 \\
$1 / 2000$ & 1.5 & .0979 & 9.8 & 2.0 & 2.74 \\
$1 / 4000$ & 0.75 & .0496 & 9.9 & 1.9 & 2.19 \\
$1 / 8000$ & 0.375 & .0104 & 4.2 & 1.1 & 0.73 \\
\hline
\end{tabular}

Legend: A commercial preparation of Salmon Testes DNA $(10 \mathrm{mg} / \mathrm{ml})$ diluted in 1XTNE was used according to Current Methods of Molecular Biology. 
Figure 50. Nucleic Acid Concentration and Cot $1 / 2$ Values

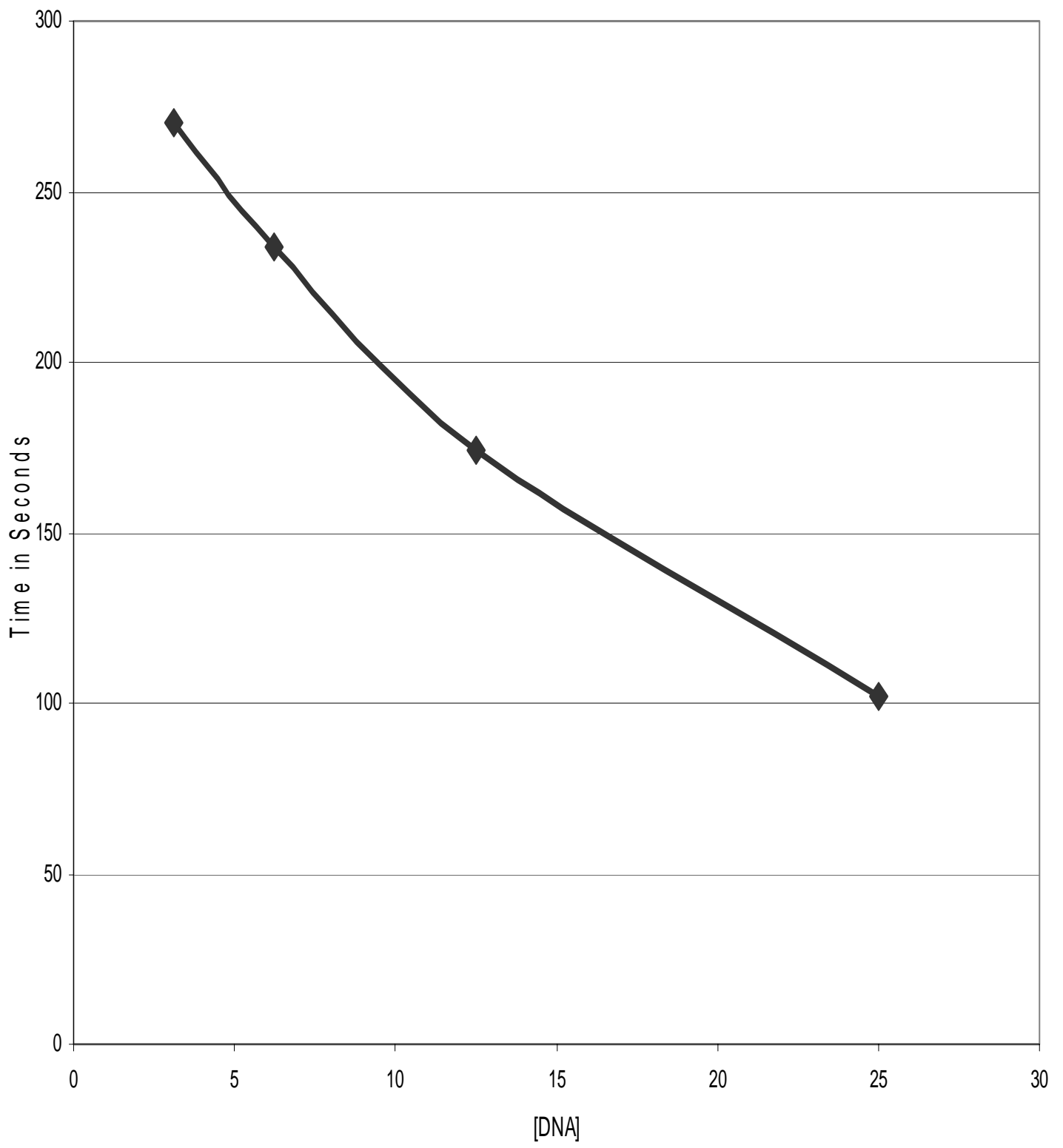

Legend: A commercial source of Salmon Testes DNA (Sigma Chemical 10mg/ml) was diluted in $1 \mathrm{XSSC}$ and absorbance recorded at $260 \mathrm{~nm}$ every 0.2 minutes after denaturing at $100^{\circ} \mathrm{C}$. Increased concentrations of the DNA preparation decreased the time necessary for $50 \%$ reassociation of the nucleic acids to occur. 
complexity, after denaturation at $95^{\circ} \mathrm{C}$ the $E$. coli was $94 \%$ of the theoretical absorbance at $100 \%$ ss DNA. Absorbance at $25^{\circ} \mathrm{C}$ was 1.4968 and at $\mathrm{T}=0$ at $95^{\circ} \mathrm{C}$ was 2.0122 . The Belt Cave sample was $76 \%$ denatured (A260 $=1.1407$ to A260 $=1.2354$ ). When reassociation rates were measured, E. coli DNA was $50 \%$ reassociated in 1.2 minutes. E. coli was quickly reassociated to nearly $0 \%$ single-stranded by the end of the experiment. However, the Belt Cave sample increased in absorbance initially and at the end of 10 minutes was only $89 \%$ reassociated based on absorbance values at $\mathrm{T}=0$. When the experiment was terminated at $\mathrm{T}=73$ minutes (4380s), DNA from the Belt Cave sample was still $73 \%$ single-stranded (Figure 51 ). These two samples were not extracted by the same method. Belt Cave sample was extracted on 4-24-01 by the SDS method. The E. coli was a commercially prepared nucleic acid (Sigma Chemical).

Another set of reassociation experiments using total genomic DNA from 10 grams of SDS extracted sediments showed higher diversity in the cave samples when compared to the surface sample of Funks Run (Figure 52). The sample from Sinking Creek was not plotted as the absorbance reading after denaturation at $100^{\circ} \mathrm{C}$ was lower than the baseline reading. After 1200 minutes, only the Funks Run and Belt 2 samples had less than $100 \%$ calculated values of single stranded DNA. 
Figure 51. Reassociation of total DNA from Belt Cave compared to E. coli at $25^{\circ} \mathrm{C}$.

\section{REASSOCIATION OF GENOMIC DNA AT $25^{\circ} \mathrm{C}$}

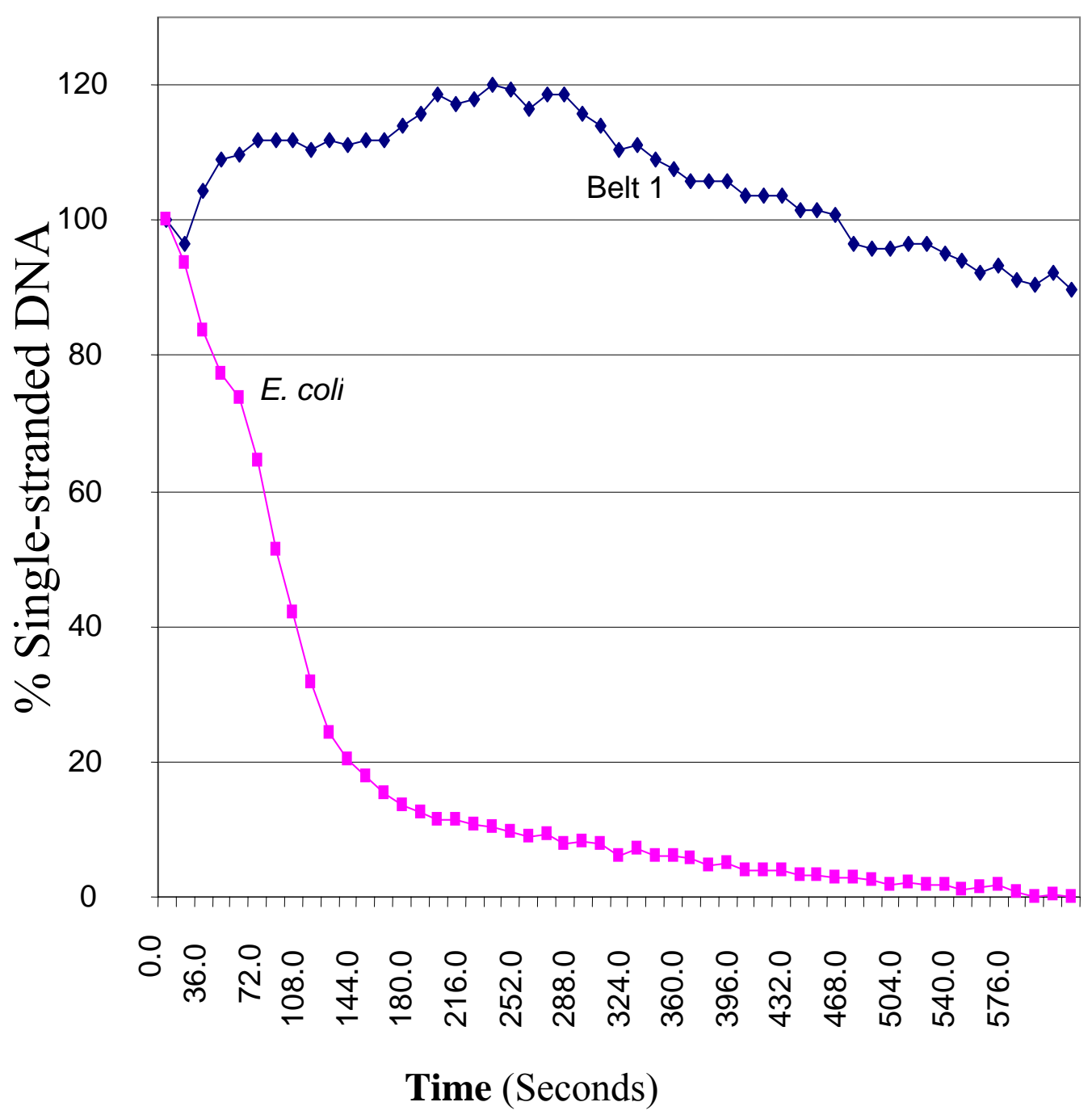

Legend: This graph shows the reassociation rates of nucleic acids from E. coli and Belt Cave genomic extracts. Experiments were conducted in 1XSSC. After baseline absorbance readings samples were denatured at $95^{\circ} \mathrm{C}$ until readings stabilized. Reassociation rates were measured at $260 \mathrm{~nm}$ wavelength at $25^{\circ} \mathrm{C}$. E. coli DNA was $50 \%$ reassociated in 1.2 minutes. However, the Belt Cave sample was still $73 \%$ singlestranded at the end of the experiment. Each mark indicates 12 seconds ( $0.2 \mathrm{~min})$. 
Figure 52. Reassociation of total extracted DNA from 10 grams of cave and surface sediments in $5 \mathrm{XSSC}$ at $25^{\circ} \mathrm{C}$.

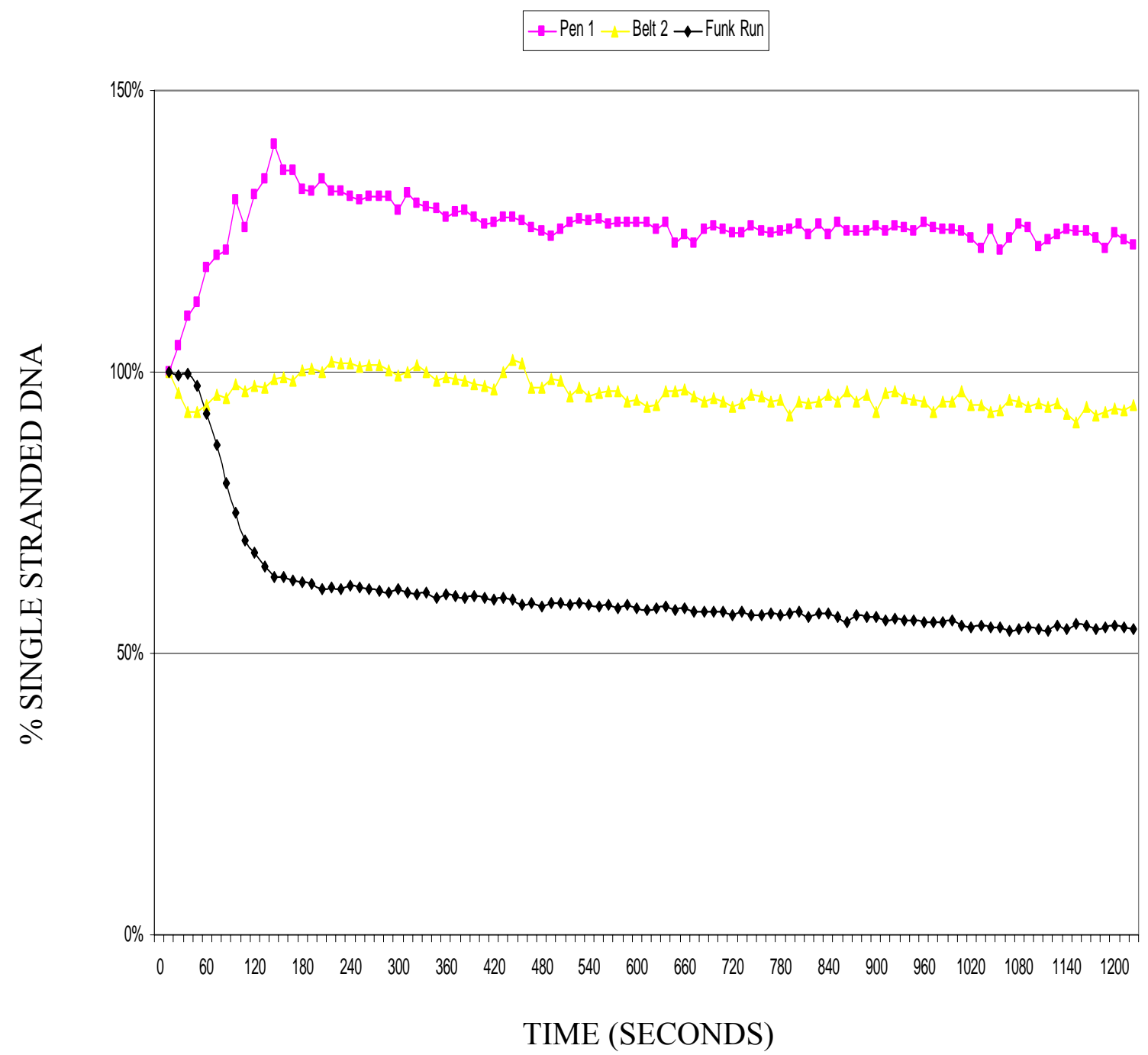

Legend: Samples were diluted 1/10 in 5XSSC Buffer and after stabilization at $100^{\circ} \mathrm{C}$, the thermal controller was disabled and absorbance was measured at $260 \mathrm{~nm}$. At the end of the experiment ( $\mathrm{T}=1200 \mathrm{~min})$, only the Funks Run and Belt 2 samples had calculated values of single stranded DNA less than $100 \%$. 


\section{REASSOCIATION OF TOTAL COMMUNITY 16S}

Absorbance of the total community $16 \mathrm{~S}$ rDNA amplicons was measured in $0.1 \mathrm{XSSC}: 30 \% \mathrm{DMSO}$ for reassociation analysis (Table 16). Initial concentrations of the two surface samples were very low compared to the other samples in the experiment. However, they were still above the minimal level for detection and accuracy for absorbance readings at $260 \mathrm{~nm}$. Reassociation analysis of the total community $16 \mathrm{~S}$ amplicons (Figure 52) showed that samples did not group together according to concentration of nucleic acids. Pen 2 and Belt 1 samples were the first to reach 50\% reannealled. There was no experimental control of E. coli with this run as there was only room for six samples in the spectrophotometer.

\section{REASSOCIATION OF CULTURED COMMUNITY 16S}

The concentration of cultured community amplicons was measured in 0.1XSSC Buffer for reassociation experiments (Table 17). Concentrations of 16S rDNA from the cultured portion of the community were much lower than those from the total community even after amplification, purification and concentration. Although the purity of $E$. coli was not acceptable, it was used as the standard for reassociation of the cultured community $16 \mathrm{~S}$ amplicons. When rates of reassociation were measured for the cultured community $16 \mathrm{~S}$ amplicons (Figure 53 ) in $0.1 \mathrm{XSSC}$ Buffer at $25^{\circ} \mathrm{C}$, all samples showed

more genetic complexity than E. coli except the Pen 2 sample. Belt 1 amplicons were still not $50 \%$ reassociated after 10 minutes when the experiment ended. 
Table 16. Absorbance values for cave and surface sediment total community $16 \mathrm{~S}$ amplicons in $0.1 \mathrm{XSSC}$ with $30 \%$ DMSO diluted 1/100.

\begin{tabular}{|l|l|l|l|l|}
\hline \multicolumn{1}{|c|}{ SAMPLE } & $230 \mathrm{~nm}$ & $260 \mathrm{~nm}$ & $280 \mathrm{~nm}$ & $325 \mathrm{~nm}$ \\
\hline 0.1 XSSC:30\%DMSO & -0.1761 & 0.0001 & 0.0002 & 0.0005 \\
\hline E. coli & 0.0969 & 0.3135 & 0.1597 & 0.0000 \\
\hline Belt 1 & 0.3010 & 0.4386 & 0.2256 & 0.0028 \\
\hline Belt 2 & 0.1549 & 0.2941 & 0.1525 & 0.0018 \\
\hline Pen 2 & 0.0000 & 0.3234 & 0.1712 & 0.0083 \\
\hline Pen 1 & 0.0969 & 0.3064 & 0.1567 & 0.0002 \\
\hline Sinking & -0.0414 & 0.0736 & 0.0389 & 0.0019 \\
\hline Funks & 0.2218 & 0.0508 & 0.0254 & 0.0004 \\
\hline
\end{tabular}

Legend: This table shows the extracts from 10 grams of sediment by SDS extraction method. All samples were amplified with UniF and UniR primers in replicates of six using $6 \mu \mathrm{l}$ of extract diluted $1 / 100$ and a total of $250 \mu \mathrm{l}$ was used for purification by Microcon centrifugal filtration. Samples from Sinking Creek and Funks run were pooled for comparison to the Cave samples by total community DNA because of the low absorbance values. 
Figure 53. Reassociation rates of total community $16 \mathrm{~S}$ amplicons from cave and surface sediment extracts at $55^{\circ} \mathrm{C}$.

\section{REASSOCIATION OF TOTAL COMMUNITY 16S AT $55^{\circ} \mathrm{C}$}

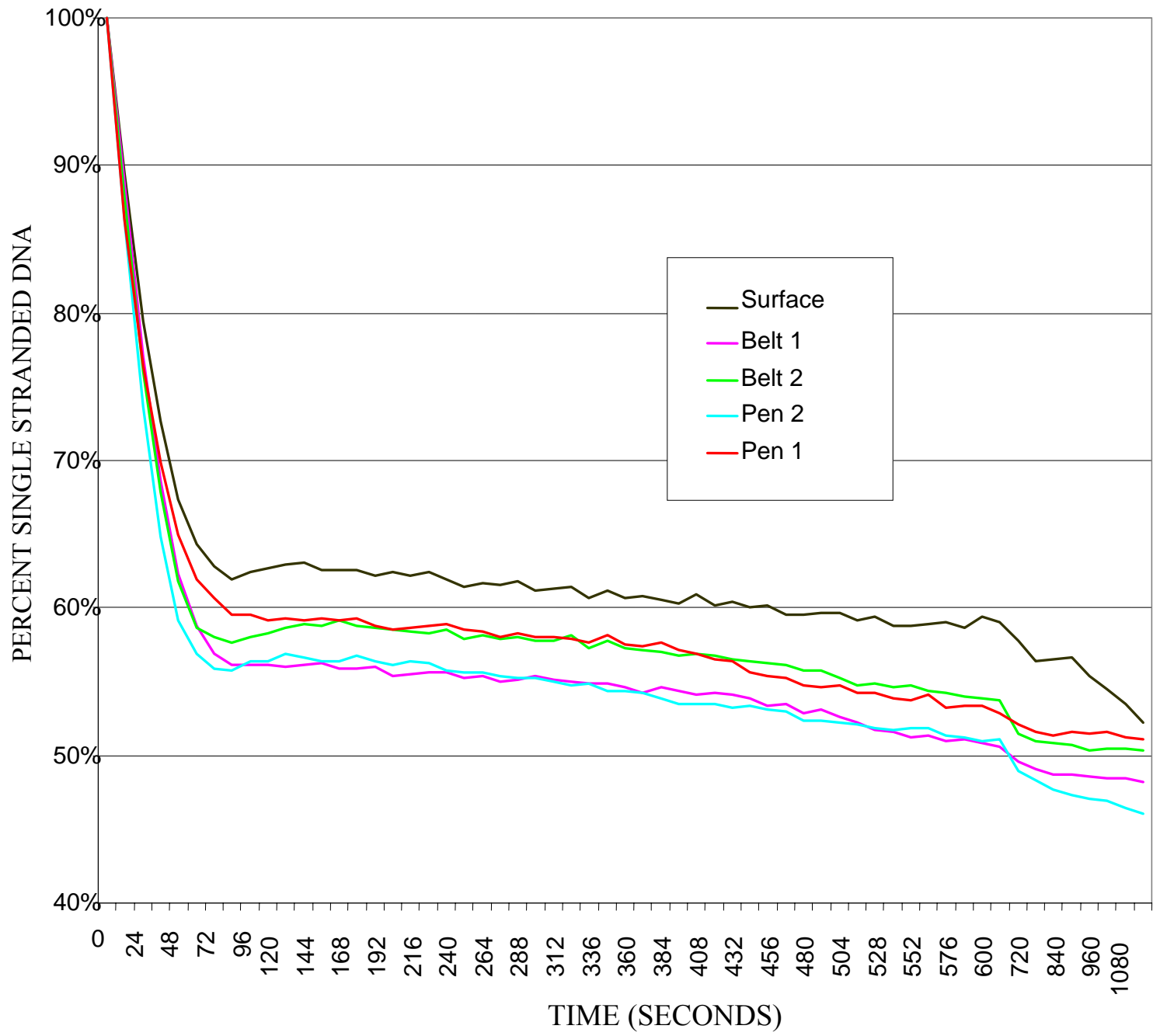

Legend: Samples were diluted 1/100 in 0.1XSSC:30\% DMSO Buffer and reassociated at $55^{\circ} \mathrm{C}$ after denaturation at $100^{\circ} \mathrm{C}$. Absorbance readings were recorded every 0.2 minutes. Belt 1 and Pen 2 samples had the least time to 50\% reannealled while the surface sample and Pen 1 samples were slowest to reassociate. 
Table 17. Absorbance readings of concentrated, cultured 16S amplicons diluted 1/100 in $0.1 \mathrm{XSSC}$ for reassociation.

\begin{tabular}{|c|l|l|l|l|}
\hline SAMPLE & $230 \mathrm{~nm}$ & $260 \mathrm{~nm}$ & $280 \mathrm{~nm}$ & $325 \mathrm{~nm}$ \\
\hline E. coli & 0.2004 & 0.0766 & 0.0520 & 0.0231 \\
\hline Pen 2 & 0.0749 & 0.2051 & 0.1032 & 0.0064 \\
\hline Pen 1 & 0.0425 & 0.0611 & 0.0295 & 0.0014 \\
\hline Funk & 0.0014 & 0.0260 & 0.0164 & 0.0064 \\
\hline Sinking & 0.0207 & 0.0397 & 0.0212 & 0.0063 \\
\hline Belt 1 & 0.0366 & 0.0715 & 0.0347 & 0.0026 \\
\hline
\end{tabular}

Legend: Samples were extracted by BIO101 method and amplified using $r$ Tth polymerase and universal primer pair (UniF and UniR) with $6 \mu$ l of undiluted extract as template. Samples were concentrated and purified by Microcon centrifugal filtration and diluted $1 / 100$ in 0.1 XSSC Buffer for reassociation analysis. The E. coli sample was not a very pure sample. The Pen 2 sample had a much higher concentration of DNA than the other samples. The Funk Run sample had a very low $230 \mathrm{~nm}$ wavelength absorbance reading. All samples were denatured at $95^{\circ} \mathrm{C}$ for measurement of reassociation rates. 
Figure 54. Cultured community $16 \mathrm{~S}$ amplicons reassociated at $25^{\circ} \mathrm{C}$.

\section{REASSOCIATION OF CULTURED COMMUNITY $16 \mathrm{~S}$ AT $25^{\circ} \mathrm{C}$}

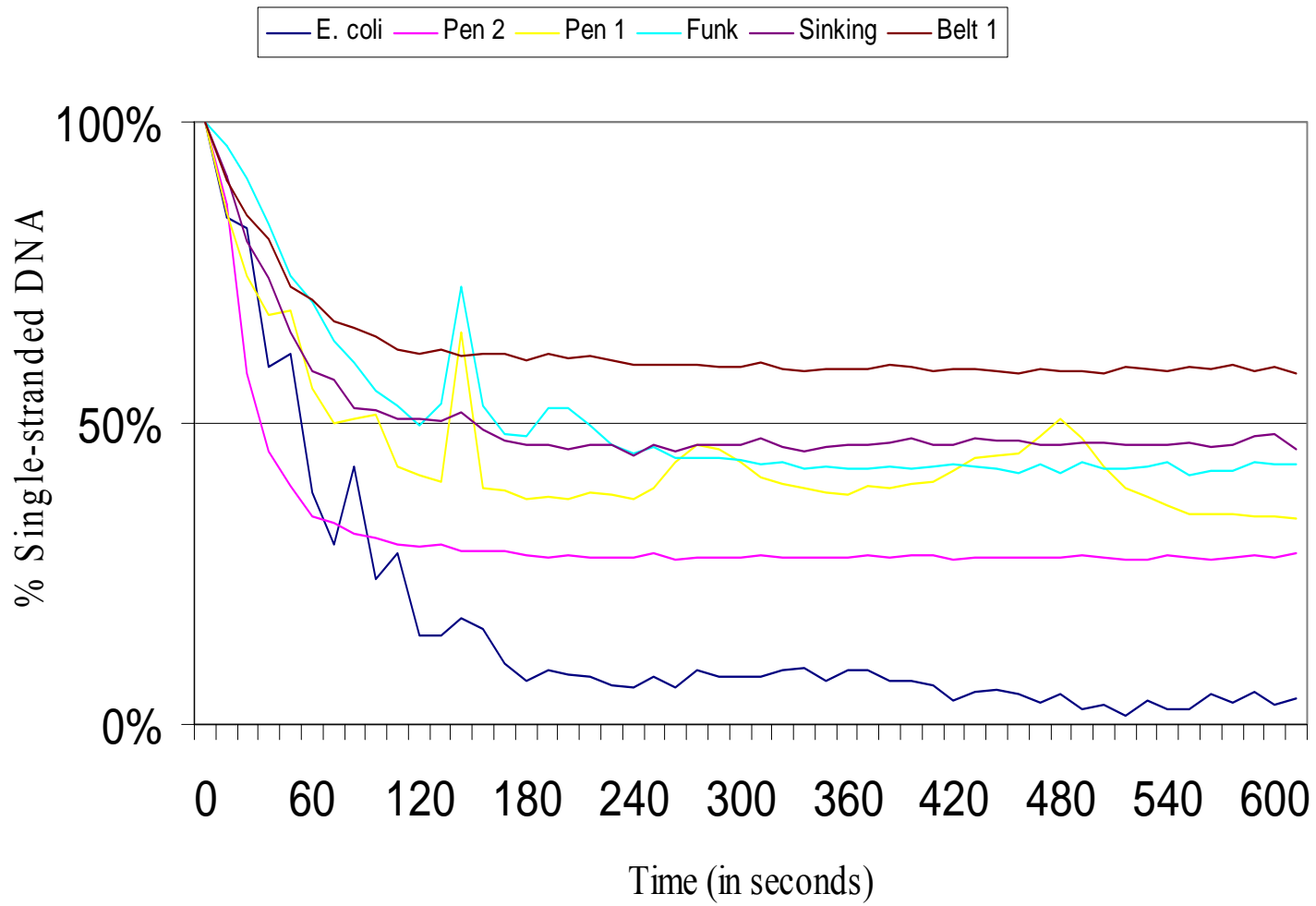

Legend: Reassociation rates for the cultured $16 \mathrm{~S}$ amplicons were quickest for E. coli $(54 \mathrm{~s})$ and the Pen 2 (30s) samples. The two surface sites had slower rates of reassociation to $50 \%$ ss. (Sinking Creek $=132 \mathrm{~s}$ and Funks Run=120s) measured. However, the DNA from the Belt 1 sample was still not $50 \%$ reassociated after $612 \mathrm{~s}$ when the experiment ended. 


\section{DISCUSSION}

Rusterholtz and Mallory (1995) emphasized the need for future studies to estimate the genetic diversity in subsurface sediments and determine if there is a correlation between genetic and phenotypic diversity. The function and importance of microbes in the karstic environment is only beginning to be studied. The development of molecular techniques has given microbiologists the ability to better survey bacteria in their natural environment and to take a more accurate snapshot in time. These techniques allow microbiologists to gain information about currently nonculturable microbes. Neither molecular nor cultivation methods alone, however, are adequate for describing bacterial diversity. Thus, a combination of culture and molecular methods were utilized in this study to characterize the microbial communities of karstic sediments. One prediction was that genetic diversity would be higher in cave sediments than in adjacent surface sediments sampled. The second prediction was that bacterial communities in cave sediments would have unique communty structures when compared to their surface counterparts.

\section{A. PHYSICAL/CHEMICAL ENVIRONMENT}

Measuring certain physical and chemical characteristics can distinguish between surface and ground water sources. For example, chloride is present in animal and human waste, and levels are generally higher in surface waters. Chloride can be introduced because of improper agricultural practices, inadequate sewage systems, salt storage for road-use, and storm water run-off. It is an indicator of human influence. The 
surface sites sampled in this study had the highest levels of chloride and the drip pool sample site in Penitentiary Cave (Pen 1) had the lowest concentration of chloride ions. Photosynthetic pigments, dissolved oxygen, temperature, and $\mathrm{pH}$ were measured as possible regulating factors of diversity or community structure.

Since aquatic communities in surface waters are primarily supported by photoautotrophs, surface waters were expected to have higher concentrations of chlorophyll. It was expected that as surface water influence decreased, pigment concentrations would also decrease. As chlorophyll is quickly degraded upon cell death, high levels of phaeophyton, a degradation product of chlorophyll, can also indicate recent contact with waters of surface origin. Levels of phaeophyton and chlorophyll a from cave water samples established the sampling sites within the cave to be distinct from those of nearby surface waters indicating no presence of pigments associated with photosynthetic activity. There were some difficulties associated with the traditional method for measurement of phaeophyton by Standard Methods for the Examination of Water and Wastewater. A cloudy precipitate formed upon acidification of samples with hydrochloric acid for phaeophyton analysis interfering with absorbance values by spectrophotometry. This was attributed to the high concentrations of calcium in collected waters. Analyses for chlorophyll $a$ and phaeophyton were eventually carried out by the fluorometric method with no interference observed.

The concentration of dissolved oxygen in water is an indicator of the biological oxygen demand due to community respiration. Oxygen saturation is calculated as the percentage of dissolved $\mathrm{O}_{2}$ concentration relative to that when completely saturated at the temperature of the measurement point and is influenced by water temperature. All dissolved oxygen readings were converted to percent saturation for comparison between 
surface and cave sites which sometimes had a considerable difference in water temperatures. The elevation of the sampling location, the barometric pressure, and the salinity of the water also affect this value but to a lesser extent. These factors were not considered. In most fresh waters, the effect of dissolved solutes (salinity) is negligible. Surface waters were $112 \%$ saturated with oxygen while cave waters averaged only $87 \%$ saturation. While the comparison of percent saturation is a better comparison than absolute $\mathrm{mg} \mathrm{O}_{2} / \mathrm{L}$, there are still problems with this method. Dissolved oxygen was measured at both surface and cave sites during midday. In the surface aquatic environment, oxygen levels are highest during midday revealing the influence of phototrophic activity. Dissolved oxygen levels are lowest in the surface environment just before dawn when much of the dissolved oxygen produced during daylight hours by photosynthetic organisms has been consumed by the respiring community overnight. Since cave waters should not experience this surge in dissolved oxygen levels, a comparison of dissolved oxygen levels in surface and cave waters at midday is suspect. Comparisons of dissolved oxygen levels and fluctuation over a 24 hour period would be more meaningful.

In addition to the stability of light and oxygen production, bacteria in the aquatic cave environment experience very little temperature fluctuation. While surface water temperatures varied between 4 and $25^{\circ} \mathrm{C}$ annually, temperatures of cave waters remained nearly constant, changing by only one degree in the waters sampled.

One would expect to see a shift in community structure in surface sediments in response to the changes of the physical environment while the lack of variation in the cave environment should allow for a more stable bacterial community in the cave sediment environment. However, the community structure at various times of the year 
was not compared. This would be an interesting follow-up to this study. ARDRA methods would allow monitoring of community structure in conjunction with measurement of environmental conditions.

Shifts in $\mathrm{pH}$ have been shown to affect bacterial community structure and diversity in other environments. Many soils and sediments studied previously have low $\mathrm{pH}$ values. All soil samples investigated by Miller et al. (1999) had pH values between 5.7 and 6.5, much lower than those from the cave environments sampled in this study. The groundwaters in this study had $\mathrm{pH}$ values between 7.5 and 8.5 with no difference between surface and cave sampling sites. $\mathrm{pH}$ is likely to be fairly consistent in the karstic region of central Kentucky as the limestone substrate provides a strong buffering capacity. However, influences from surrounding land use have been demonstrated to have brief but significant effects on the water chemistries of karstic streams in this area. It has been demonstrated that water quality at many karst springs in the Mammoth Cave Big Spring area undergo high amplitude but relatively brief periods of degradation. Studies have included measurements of specific conductance and dye tracers which indicate significant connections between surface and subsurface aquatic environments (Ryan and Meiman 1996).

The different physical and chemical environment in which cave microbes live was established by the measurement of a variety of parameters known to affect microbial communities in other more studied environments. However, the sampling occurred on an infrequent basis over a time period of four years. As Ryan and Meiman (1996) pointed out, rigorous or even continuous sampling protocols are necessary to determine connections between surface and subsurface aquatic environments. The chemical and physical data collected in this study did, however, demonstrate that different solutes and 
nutrients are available to the cave and surface sediment bacterial communities sampled.

A paper describing the water chemistries of cave and surface sediments in and near Pettyjohns Cave in Northwest Georgia by Mayer (1999) found that compared to cave waters, surface waters are very dilute and deficient in calcium, magnesium, and bicarbonate ions. While surface waters contained between 0.62 and $1.05 \mathrm{mg} / \mathrm{L}$ of calcium, cave waters from drip pools had levels of 49.1 up to $70.69 \mathrm{mg} / \mathrm{L}$. Levels of calcium in water column samples from this study did not differ between cave and surface sites. Calcium in surface waters averaged $55.60 \mathrm{mg} / \mathrm{L}$ while cave waters had average concentrations of $45.75 \mathrm{mg} / \mathrm{L}$. The buffering capacity of the substrate in surface streams in this karstic area and the frequency with which streams discharge to the surface and sink again could help explain the high levels of calcium in surface waters in this area.

Total dissolved ion concentrations (TDI) in Pettyjohns Cave were 10-30 times higher from cave drip pools than adjacent surface waters. Total dissolved ions (TDI) are used to indicate residence time within an aquifer as percolation through soils should allow binding of free ions with soil particles or other charged components. Industrial effluents or paved surface runoff may contribute to the conductivity of waters. Samples from this study showed conductivity levels to differ between the two caves sampled. Penitentiary Cave samples averaged higher than those of adjacent Sinking Creek but neither cave site had conductivities significantly higher than those of the surface sites sampled. However, conductivities of waters in Penitentiary Cave were significantly higher than those waters sampled in Belt Cave. Belt Cave samples averaged $282.5 \mu \mathrm{S}$ while waters in Penitentiary Cave averaged $477.8 \mu \mathrm{S}$. Those waters sampled from surface sites averaged $340 \mu \mathrm{S}$ in Funks Run, adjacent to Belt Cave and $401 \mu \mathrm{S}$ in Sinking Creek near Penitentiary Cave. When ranking the six sampling sites for the various parameters measured, 
Penitentiary Cave site (Pen 1) had the lowest concentrations of total nitrogen, nitrites + nitrates, soluble reactive phosphorus (SRP), and chlorides. The same site ranked highest for conductivity, silica, and dissolved organic carbon. This indicates that the waters at this site have experienced a longer residence time in the ground water system and therefore, are less influenced by surface land use.

The two sites from Belt Cave had the lowest levels of DOC (21.21 mg/L), while samples from Penitentiary Cave had higher levels similar to those in the surface waters of Sinking Creek (all 38-40 mg/L). However, the source of this DOC and the factors regulating levels of DOC in Penitentiary and Belt Cave areas are unknown.

In caves, organic materials may come from waste material from cave-dwelling animals, dissolved matter in drip water, or plant remains washed or blown in from the surface. Organic material is also obtained from the fecal matter of trogloxenes, animals that periodically spend time outside the cave, such as bats, cave rats, and crickets.

Bacteria are eaten by protozoa and biofilm grazers including aquatic cave organisms such as flatworms, isopods, and amphipods. These small invertebrates are eaten by larger animals in the cave environment (eg. crayfish, salamanders, and fish). Finally, all of these aquatic animals support the microbial decomposers that helped to initiate the chain with their waste products and cell constituents upon death.

\section{B. DNA EXTRACTION AND PCR AMPLIFICATION}

Since previous studies indicate the highest yield from a variety of soil and sediment samples was obtained by the use of both mechanical and chemical extraction, the method chosen for this study consisted of bead-beating with the addition of a chemical lysing agent. The extraction of nucleic acids by direct lysis methods are non-selective and 
include both eukaryotic and prokaryotic DNA. After extraction, there are no good methods for distinction. Extractions from sediments in this study were performed directly from the matrix and included DNA from living and non-living cells. In addition, one cannot ignore the possibility of free DNA in the sampling environment (Farrelly et al. 1995). This must be considered when making conclusions regarding the community structure.

Ten gram samples of sediment were used in this study. It was necessary for the extracts from these study samples to be diluted $1 / 100$ or $1 / 1000$ for amplification of the 16S rRNA gene. This agrees with results from Miller (1999) in which amplification of three types of soil or sediment extracts was successful for all samples only at dilutions of $10^{-2}$ for all purification procedures used, including SpinBind columns, gel electrophoresis, and Sephadex G-200 columns. Ammonium acetate precipitated samples required dilution of $10^{-3}$. Tebbe and Vahjen (1993) found that soil required a dilution of 1:1000 while soil DNA extracted by Yeates and Gillings (1998) was diluted 1:200 before digestion. Tsai and Olson (1992) also found it necessary to dilute DNA template for successful PCR even after purification using Sephadex G-50 or Bio-Gel P 6 columns. However, dilution of inhibiting compounds cannot be performed in isolation. Dilution of inhibitors also reduces the percentage of the sampled population.

There has been a concern that dilution of template DNA would eliminate rare DNA from the sample. While the concern over the representation of entire community DNA may be justified, PCR based methods for evaluating bacterial diversity in soils and sediments have been found to be acceptable for determining community structure of dominant phylotypes. Denaturing gel gradient electrophoresis (DGGE) has been used to demonstrate that dilution of template to extinction does not affect the pattern of major 
bands (Muyzer et al. 1993).

The method of extraction used in this study provided a high yield of DNA. Expected yields from the BIO101 SpinKit for Soil were 1-50 micrograms depending on the source and number of organisms present (BIO 101 Protocol). Samples in this study yielded DNA in the $20-54 \mu \mathrm{g} / \mu 1$ range for $0.500 \mathrm{gm}$ samples extracted by the BIO101 method. As was previously mentioned, all DNA measured by spectrophotometry is not prokaryotic DNA. However, by both spectrophotometry and visualization by gel electrophoresis, there appeared to be ample DNA for PCR amplification of bacterial ribosomal genes. While approximately $10 \mathrm{ng}$ of DNA is necessary for a PCR reaction, even samples which give negative readings at $260 \mathrm{~nm}$ have been successfully amplified by PCR. The modified FastDNA Kit for Soil and the modified Zhou et al. (1996) extraction protocols both yielded DNA in the size range of greater than 10 $\mathrm{kb}$ as evidenced on a $1 \%$ agarose gel. This is well above the size necessary to amplify the 16S rRNA gene.

Bruggemann et al. (2000) stated that extraction efficiency should not be calculated using gel electrophoresis band intensities as copy numbers of the rRNA gene per genome of uncharacterized environmental organisms is unknown. This can introduce errors in translating band intensity to cell numbers. Samples from this study submitted to Epicentre for the purpose of developing a soil DNA extraction kit, were among the most difficult from which to obtain nucleic acids (EpiCentre Forum). However, the method chosen to evaluate extraction efficiency in this study proved impossible. Concentrations of actual DNA obtained in the extracts far exceeded calculated concentrations of theoretical yields of DNA from sediments. This method may have failed because of the use of and in-situ extraction method. Since cells were not separated from the sediment 
samples before extraction, extracts in this study contained both prokaryotic and eukaryotic DNA in addition to other naked DNA in the environment from viruses or dead cells. Other studies using in-situ extraction methods found that extraction efficiencies were greater than $100 \%$ based on an average of 9fg DNA per bacterial cell (Lewin 1994). Nusslein and Tiedje (1999) counted bacterial cells in both pre- and post-extracted sediments to predict theoretical yields, but this does not address the problem of measuring the actual prokaryotic DNA obtained. Although I was unable to calculate extraction efficiencies, extraction methods in this study yielded sufficient concentrations of DNA for amplification by PCR. However, since extraction efficiency could not be calculated accurately with the methods chosen, it is not known what percentage of cells in the sediment samples were in fact lysed.

Since DNA was obtained and could be visualized both on agarose gel and verified by absorbance at $260 \mathrm{~nm}$ by spectrophotometry, cell lysis and extraction does not appear to be a factor in these particular samples. Experiments using cave sediment extracts and spiking with E.coli yielded PCR product in the E.coli template only control but in none of the spiked samples.Also, because DNA extracted from E. coli when mixed with cave sediment extract was not amplifiable, cell lysis was not likely to be the problem. This experiment also demonstrated that it made no difference if the DNA was extracted together or mixed after extraction. Therefore, it seems as though it is not a binding of DNA during extraction that is preventing amplification by PCR.

However, PCR amplification from direct extracted cave and surface stream sediments proved inconsistent and unpredictable among samples. In spite of adequate size fragments of extracted genomic DNA from both surface and cave sediments, no PCR product could be obtained using either of two sets of primer pairs. However, E. coli cells 
subjected to the same extraction protocol yielded appropriate size product from both sets of primers. To determine if the primers selected for this study were suited to amplify DNA from the cave environment, samples cultured from the cave pools were scraped from the plates and emulsified with water. Five hundred microliters of the emulsified sample was used for extraction and all samples were successfully amplified using both the UniF/ UniR and the Eub1/Eub 2 primer sets. Other positive controls from single organisms also were successfully amplified by all sets of primers. It is possible that the bacteria cultured were of surface origin and not a major component of the cave microbial community. However, as the bacteria was cultured at $4{ }^{\circ} \mathrm{C}$, it is more likely that inhibitors found in the extracts, and not the bacterial origin, were responsible for the lack of PCR product from the sediments sampled.

Although the BIO 101 kit contains a proprietary silica matrix for the purpose of eliminating contaminants which inhibit PCR reactions, the extracted DNA proved not to be very pure as indicated by high absorbance readings in the $230 \mathrm{~nm}$ wavelength range. Purity of samples extracted in this study gave A260/A280 ratios in the 1.07 to 1.31 range. Absorbance ratios of A260/A230 for extracts from sediments in this study were 0.25 to 0.47. Attempts to purify the extracted DNA using a GeneClean kit and EtOH precipitation failed to improve readings. To increase purity, experiments were performed adding $50 \mathrm{mg} / \mathrm{ml}$ of acid-washed PVPP to the extraction buffer. In spite of treatments with PVPP, A260/A230 only reached 0.56 to 0.65 . When samples were extracted with $50 \mathrm{mg}$ of acid-washed PVPP, which functions to bind inhibitors during extraction, A230/A260 ratios did improve slightly. However, A260/A230 ratios remained below that of other studies. Ratios of A260/A280 did not change or were slightly lower in all samples both surface and cave ( $x=1.2075$ before and $x=1.145$ after). 
A260/A230 ratios increased, or improved, but were still in the unacceptable range. Although ratios of A260/A280 should be near 2.0, successful amplification of the $16 \mathrm{~S}$ rRNA gene has occurred with an A260/A280 ratio as low as 0.99 (Leff et al. 1995).

While nucleic acid purity was not acceptable according to the standards used, samples in this study were similar in quality to those of other sediment studies and dilution of the template DNA did allow amplification of the $16 \mathrm{~S}$ ribosomal gene. Results of the E. coli spiking experiment suggests that inhibitory compounds, rather than inadequate cell lysis or DNA template, was responsible for the failure of PCR.

Since calcium carbonate dominates the chemical composition of cave environments, and there are numerous previous studies which implicate calcium in PCR inhibition, calcium was of special concern in this study. However, the nearly equal concentrations of calcium from surface and cave waters in this study effectively eliminated a control. To evaluate the inhibitory effect of calcium on PCR at the levels found from cave waters, reactions were set with adequate template DNA from E. coli and spiked with varying amounts of calcium carbonate or calcium chloride. Only those samples with the lowest concentrations of calcium present were successfully amplified. This indicates that calcium could indeed be the inhibiting substance in these samples. Calcium in high concentrations can interfere with polymerase and, in excess, can react even with template DNA added after extraction.

It should be noted here that when solutions of calcium carbonate and calcium chloride were scanned by spectrophotometer, and the six highest peaks chosen, two of these peaks were 255.5 and $258.5 \mathrm{~nm}$. Therefore, it is possible that calcium in the nucleic acid extracts could have interfered with absorbance readings at $260 \mathrm{~nm}$, the wavelength for measuring concentrations of DNA. This is a possible explanation for the anomalously 
high readings of some samples during reassociation experiments.

Extracts performed by the BIO101 method from cave sediments contained from 8.98 to $14.1 \mathrm{mM}$ of calcium. After accounting for the dilution, amplification reactions contained from 0.17 to $0.28 \mathrm{mM}$ of calcium using $1 \mu 1$ of extract. While these values are below those found to inhibit PCR, extracts also contained other possible inhibitors. All extracts were yellow to brown in color indicating the presence of humic or other organic acids The presence of such high levels of calcium in the extracts did not appear to alter the optimal $\mathrm{Mg}^{++}$concentrations necessary for successful amplification of template DNA. However, the BIO101 samples were not acceptable for use in total genomic DNA analyses due to contaminants and low concentrations.

The samples used for ARDRA and reassociation of total community $16 \mathrm{~S}$ were extracted from 10gm sediment by the modified Zhou et al. (1996) protocol. Sediments and extracts were compared by converting all units to ppm. It is not certain that this is an appropriate comparison. However, if samples are compared in this manner, then extracts were significantly reduced in calcium $(x=48.02 \mathrm{ppm})$ compared to the sediments from which they were extracted $(x=683.23 \mathrm{ppm})$. They remained above levels necessary for inhibition of amplification by PCR. When dilution of the samples is considered, PCR should not be inhibited by calcium concentrations alone. Samples were initially diluted $1 / 100$ or $1 / 1000$ before a final dilution of $6 \mu 1$ of the diluted extracts/50 $\mu 1$ amplification reaction.

Experiments were also performed to evaluate the efficiency of several polymerases in the PCR reaction. Al-soud (1998) discovered that some DNA polymerases are more sensitive to calcium inhibition than others. These experiments also agreed that rTth polymerase was less sensitive to the inhibitors present in these samples. The rTth 
polymerase did slightly improve the efficiency of PCR in the cave samples both by increasing product at higher levels of calcium carbonate and by producing less nonspecific product.

The inhibition of PCR is very complex and much is still unknown about the inhibitors in various samples, and the mechanisms by which they work. Evaluation of PCR i inhibition requires an analysis of each sample type, including which inhibitors may be present and by what mechanism these inhibitors affect PCR. In this study, the most likely mechanisms by which PCR was inhibited, was by sequestration of freed DNA, or prevention of DNA polymerase binding to the template. Since the calcium levels were greatly reduced in the extraction process and the samples still required dilution of either $1 / 100$ or $1 / 1000$, probably other factors contributed to the difficulties in amplifying $16 \mathrm{~S}$ rDNA from the sediments sampled.

In many cases, it was impossible to eliminate amplification in the PCR cocktail with no added template. In many of the inhibition experiments, a product from the notemplate control would be the only band visible on agarose gel. The presence of DNA sequences in Taq polymerase has been noted in earlier studies (Wilson 1997; Hughes et al. 1994). However, when samples were amplified for reassociation and digestion, the cocktail band was eliminated by centrifugal filtration of the PCR cocktail before addition of the polymerase and careful dilution of primers and template for use.

\section{MICROBIAL COMMUNITIES}

In this study, microbial communities in several different cave sediments and adjacent surface sediments were characterized using both cultural and molecular approaches. To provide the most accurate information on the whole bacterial community, ten gram 
samples were extracted directly from the soil matrix with a method chosen to provide the highest yield of DNA from a soil sample (Zhou et al. 1996). In addition, extracts were used at the highest concentration of template which still allowed amplification of the $16 \mathrm{~S}$ rDNA. After purification and shearing, these DNA extracts were used for assessing genetic complexity of the total community DNA. Diluted extract $(6 \mu 1)$ was used for PCR.

The most likely disturbance to bacterial communities in cave sediments involves flooding and the influx of solutes carried into the cave system. Since total extracted DNA contains both genomic and plasmid DNA, and since presence is not an indication of any functional importance, this method did not provide information regarding the roles microbes play in this environment. Without culture analyses in addition to molecular methods for community analysis, the importance or function of some microbes in the cave environment may be misinterpreted. The function and activities of cave microbial community members should be addressed by cultural methods. This may include the inoculation of Biolog plates or amplification of $16 \mathrm{~S}$ from the wells of Biolog plates.

Cultured communities were extracted by the BIO101 method with no additional treatments necessary for amplification by PCR. Therefore, it was possible to use $6 \mu 1$ of undiluted extracts as PCR template compared to $6 \mu 1$ of $1 / 100$ diluted extract from the total community DNA of the same sediments. It is assumed that extraction efficiency of the cultured members of the community was acceptable to represent the major components. Replication of amplification reactions both decreased the sampling error and increased the theoretical diversity of amplicons in the pooled sample to be used for digestion and reassociation of the $16 \mathrm{~S}$ amplicons from both the total and the cultured communities. 
Results from this study indicate that 0.1 to $0.0001 \%$ of the communities contained in the sediments sampled were culturable on R2A agar at $4^{\circ} \mathrm{C}$ after 16 days. Plate counts on R2A from Belt Cave were $7.00 \times 10^{2}$ cfus/gm while a sample from the drip pool in Penitentiary Cave yielded $2.86 \times 10^{4} \mathrm{cfus} / \mathrm{gm}$ of sediment. Numbers of culturable bacteria were similar in both cave and nearby surface sediments. Lower counts, however, were found at Belt Cave and Funks Run when compared to culturable bacteria counted on R2A from Penitentiary Cave and the nearby surface site at Sinking Creek. Differences in DOC between sites may help explain lower bacterial cell numbers in the Belt Cave sediments sampled. Cell numbers did not correlate with the diversity of these populations.

Average particle size was correlated with cell numbers both by direct and plate counts. However, while plate counts were positively correlated with average particle size of the sampled sediment $(\mathrm{r}=.8312)$ direct counts were found to be inversely related to average particle size of the sediment $(\mathrm{r}=-.5650)$. This could be due to the fact that cells associated with sediments of larger average particle size were more easily removed with the plate count method chosen. Previous studies have indicated that certain categories of particle size have a greater proportion of the bacterial population associated. However, that was not investigated in this study.

Belt Cave sites had lower dissolved organic carbon (DOC) levels than those found in Penitentiary Cave and Sinking Creek. This site also produced the lowest number of cfus on $\mathrm{R} 2 \mathrm{~A}$ at $4^{\circ} \mathrm{C}$ and the least complex band pattern from the cultured community $16 \mathrm{~S}$. Cultured community $16 \mathrm{~S}$ digestion produced patterns with as few as four bands present after digestion with restriction enzymes. In Mammoth Cave when the only difference between sites was the amount of water received ( equal DOC), there was still a 
difference in populations. Increased water led to increased cell counts. While water influx was not measured in this study, the sites did not contain equal amounts of dissolved organic carbon. Flooding has been shown to decrease diversity of other groups of cave organisms when compared to the diversity in caves which do not flood. In the case of equal concentrations of DOC and the increased stability of the cave system, there should be a higher diversity of bacteria in the cave environment. The site with the lowest number of culturable colonies at $4^{\circ} \mathrm{C}$ (Belt 1), did exhibit evidence of flooding during the sampling period. One set of culture plates were irretrievable due to high waters.

While there were differences in the chemical and physical characteristics of the cave and surface sites, and differences between the two cave environments, the inability to distinguish between genetic complexity of the cultured 16S rDNA by ARDRA precluded any attempt to determine the factors regulating diversity in these karstic bacterial communities.

Culver and Sket (2000) made a general statement that the number of species in any one cave or subsurface site will be lower than the number of species in the region. While not necessarily an indication of species richness or evenness, communities exhibited band patterns of equal complexity. The similarity of band numbers in ARDRA signatures between surface and cave cultured communities could be due to the fact that the culture of bacteria was carried out at $4^{\circ} \mathrm{C}$, possibly increasing the number of cave species cultured, while decreasing the number of surface bacteria cultured on R2A. An interesting comparison might be to compare ARDRA signatures of communities cultured under a variety of environmental conditions. The community structures from the cultured community of the cave sites studied, were different between caves and linked more closely to the adjacent surface sediments than to each other. ARDRA signatures created 
from the cultured portion of the community did not contain bands in common with E. coli. The signatures created from the total community $16 \mathrm{~S}$ were more complex than signatures generated from the culturable portion of the communities. ARDRA patterns created from total community $16 \mathrm{~S}$ amplicons digested with Hha, RsaI, and BanI in this study all contained the signature bands from the portion of the community cultured on $\mathrm{R} 2 \mathrm{~A}$ at $4^{\circ} \mathrm{C}$.

Analysis of 16S DNA amplified from many unique and oligotrophic habitats has already been used to provide valuable information (Martinez-Murcia et al. 1995). Because this genetic region is highly conserved within species, diversity within 16S DNA is reconcilable with taxonomic diversity by classical culture methods. Methods similar to those in this study have revealed differences in communities from normal and hypersaline environments. Differences were independent of the enzyme used and were consistent with results obtained by isolate analysis (Martinez-Murcia et al.1995). Community profiling and bacterial identification with ARDRA and other 16S methods are being used in agriculture, medicine, and soil studies but methods have not been standardized. Also, there remains no standardized method for assessing bacterial diversity in soils and sediments. Each sample for analysis requires optimization of DNA extraction, purification, and subsequent PCR amplification, based upon the unique physical and chemical characteristics of the sample.

Concerns with PCR based community analyses are primarily because of possible PCR bias during amplification and the diversity of rRNA copy number and heterogeneity of rRNA operons within bacterial genomes (Wintzingerode et al. 1997). While gene redundancy is uncommon in prokaryotes, the rRNA gene can vary in copy number from one to as many as fifteen (Klappenbach et al. 2001). While the creation of a database 
of ribosomal gene copy number (rrndb) will be valuable to microbial ecologists attempting to assess diversity utilizing $16 \mathrm{~S}$ rDNA, and knowledge of the genome size and rrn copy number is necessary, such knowledge will now allow us to predict the ratios of $16 \mathrm{~S}$ product. Nor, with the methods available, will we be able to quantify species evenness of microbial communities using analysis of 16S rDNA clone libraries (Farrelly et al. 1995).

Different handling procedures of sediment samples from below the sea floor of the Japan Sea resulted in different dominant sequence types within the generated clone libraries (Rochelle et al. 1994). Inasmuch as the power of this technique lies in comparative community analysis, considerable attention must be paid to standardizing all parameters during the processing of the samples, so that any differences detected in community profiles can be attributed to differences in community structure rather than to differences in sample preparation.

The average bacterial 16S rRNA molecule has a length of 1,500 nucleotides (Amann et al. 1996). Stackebrandt and Goebel (1994) demonstrated that 16S rDNAs with $99 \%$ to $100 \%$ homology do not belong to the same species as they share less than $70 \%$ homology when compared by DNA-DNA hybridization. Bacterial strains with less than 97\% homology in the 16S rDNA never had more than $60 \%$ DNA-DNA hybridization. However, this high similarity of $16 \mathrm{~S}$ rDNA sequences can make comparison of genetic diversity by use of reassociation kinetics of this molecule difficult. The average level of similarity of $16 \mathrm{~S}$ rDNA sequences having identical RFLP patterns was $86.88 \%$ (median, $89.89 \%$; range, 52.16 to $99.85 \%$ ) based on an analysis of 427 nucleotides (Dunbar et al. 1999). However, evidence supporting the ability to detect differences in 16S rDNA is found in the fact that TGGE techniques allowed separation of Nitrosospira 16S rRNA 
genes differing by as little as one base pair (Hastings et al. 2000).

Reassociation kinetics experiments involved plotting the percentage of double stranded DNA over time while manipulating the temperature. The differential absorption of single stranded v. double stranded DNA allows for this measurement. This is a measure of genetic potential in microbial communities regardless of the environmental conditions. After denaturation, more diverse fragments will require more time to find complementary strands and become double stranded.

It was thought that reassociation curves from amplified DNA could provide a rapid assessment of taxonomic diversity. However, there are some difficulties with the use of reassociation kinetics for $16 \mathrm{~S}$ molecules related to sample purity and concentrations of the buffer and nucleic acids contained. Concentrations of DNA and buffer have effects on the reassociation rates whether evaluating genomic or ribosomal DNA. Reassociation requires high concentrations of DNA which were only obtained by pooling replicate PCR samples. Also, very pure samples are necessary for reassociation kinetics. Procedures for cleaning and purification of DNA extracts can lead to high loss of DNA as demonstrated by absorbance readings before and after purification steps in this study. In addition, when sediment extracts were not pure, absorbance readings increased upon denaturation, contrary to expected results. As a result, it was not possible to calculate reassociation rates for these samples.

Reassociation of total genomic extracted DNA from Belt Cave compared to a surface sample and that of $E$. coli indicated that microbial communities in cave sediments are more genetically complex than those from nearby surface sediments. This may be due to the selective pressure towards general rather than specialized nutritional requirements. However, this did not agree with results from the reassociation of $16 \mathrm{~S}$ amplicons. In 
addition, it does not agree with previous studies of diversity of other groups of cave organisms. In general, diversity in caves is low compared to surface habitats (Culver and Sket 2000). It has been stated that small and isolated populations of some cave organisms exhibit less genetic variation than populations of their surface counterparts (Borowsky and Vidthayanon 2001). Some of the reasons cited by Culver and Sket (2000) are reduced subterranean habitat diversity and reduced food resources. The seemingly high genetic diversity of total genomic DNA as evidenced by reassociation when compared to that of the amplified $16 \mathrm{~S}$ rDNA could be due to a variety of factors. It is possible that the majority of diversity found in cave sediments is not prokaryotic or that the 16S rDNA from bacteria found in the cave sediments was not amplifiable. Alternatively, much of the diversity of prokaryotes in this environment may be found within plasmid DNA, or archael bacteria may be more abundant than current thought. Previous studies indicate that archaea are not a dominant component of soil ecosystems (Ueda et al. 1995; Borneman et al. 1996; Borneman and Triplett, 1997; Bickley et al. 1996; Nakatsu et al. 2000). However, in aquatic ecosystems, archaea appear to constitute a significant proportion of deep, subsurface water communities (Fuhrman et al. 1993). Future studies of these cave communities might involve the use of primers for archaeal bacteria or other groups such as functional or specific genes. It could also target genes involved in thermoregulation as some cave organisms are adapted in this way.

While physiological functions were not directly examined, at least some characteristics appeared to reflect physiological adaptation to the cave environment. In addition to the difference between levels of chlorophyll $a$ in surface and cave waters, the colonies formed from surface sediments on R2A plates were more darkly pigmented than those from cave sediments. This is not an indication of diversity or genetic 
complexity, but of different community structure. Pigmentation which provides protection from light radiation, is not necessary in environments where no protection from light radiation is needed. This is similar to studies of other cave organisms and should be investigated further. Future experiments should include analysis of bacterial pigments and to determine if these subsurface species have adapted to the cave environment.

\section{CONCLUSIONS}

At the outset, the plan was to do more molecular analyses. However, it became necessary to figure out how to overcome limitations for amplification of the 16S rDNA. Inhibition of PCR turned out to be related to calcium in karst environments reacting with freed DNA to prevent binding of the DNA polymerase. In addition, other inhibitory compounds likely played a role in both amplification and spectrophotometric analyses.

Using the water chemistries measured, subsurface and adjacent surface waters were more similar than the distinct cave samples. However, the genetic complexity of both cultured and total community DNA from this site was equal to those of other sites indicating that genetic diversity may indeed be increased by the stability of the environment.

With regards to the two hypotheses of this study, the following conclusions can be drawn:

1) Bacteria in cave sediments will have unique community structures when compared to those of adjacent surface stream sediments. Indeed, indications were that microbial communities were different from each other both by culture and molecular methods. Conclusions regarding the microbial community structure in the sediments sampled are 
that the subterranean waters sampled did not indicate the presence of chlorophyll $a$ or phaeophyton, pigments associated with photosynthetic activity. In addition, pigmentation of the colonies formed on R2A agar from cave sediments was less than those from adjacent surface sediments. This may be an adaptation to the cave environment and should be investigated further. There were also significant differences in cell numbers between sites both by direct and plate count methods. Digestion of the 16S amplicons showed that while E. coli was not part of the cultured community, the total community $16 \mathrm{~S}$ contained the same banding pattern as that produced by the control organism E. coli. The regulating factors of these differences in remain unclear. However, community structure may be influenced by surrounding land use.

2) Genetic diversity will be higher in cave sediments than in adjacent surface sediments. From the molecular analyses that were carried out, genetic diversity in cave sediments was at least equal to and in some cases higher than genetic diversity in adjacent surface sediments as measured by reassociation rates. Information about genetic potential can predict the ability of a microbial community to respond to changing environmental conditions or stressors. However, the role of observed genetic complexity in bacterial DNA isolated from cave sediments in response to disturbance remains unresolved. Methods for comparing different communities by reassociation must be carefully optimized, standardized and monitored to minimize interference with data interpretation.

Continued monitoring of community structure and diversity of the microorganisms in subterranean environments is necessary to discover and protect the function of these microbial communities. ARDRA will continue to be a useful tool for the study of community structure. Since other studies have indicated little or no overlap in communities sampled by culture and molecular methods, future studies should include 
both culture and molecular methods in conjunction with rigorous sampling to gain an accurate picture of the role these bacteria play in the cave ecosystem. 


\section{REFERENCES}

Abbaszadegan M, Huber MS, Gerba CP, and Pepper IL. 1993. Detection of enteroviruses in groundwater with the polymerase chain reaction. Applied and Environmental Microbiology 59: 1318-1324.

Adams GA and Wall DH. 2000. Biodiversity above and below the surface of soils and sediments: Linkages and implications for global change. BioScience 50: 10431048 .

Alexander M. 1977. Introduction to soil microbiology. John Wiley and Sons, New York, N.Y.

Al-Soud WA, and Radstrom P. 1998. Capacity of nine thermostable DNA polymerases to mediate DNA amplification in the presence of PCR-inhibiting samples. Applied and Environmental Microbiology 64: 3748-3753.

Amann RI, Ludwig W, and Schleifer K. 1995. Phylogenetic identification and in situ detection of individual microbial cells without cultivation. Microbiological Reviews 59: 143-169.

Amy PS, Staudaher MV and Seidler RJ. 1990. Comparison of gene probe with classical methods for detecting 2,4-dichlorophenoxyacetic acid (2,4-D)-biodegrading bacteria in natural waters. Current Microbiology 21: 95-101.

Angert ER, Northrup DE, Resenbach A-L, Peek AS, Goebel BM and Pace NR. 1998. Molecular analysis of a bacterial community in Sulphur River, Parker Cave, Kentucky. American Mineralogist 83: 1583-1592.

Atlas, R.M., 1981. Microbial Degradation of Petroleum Hydrocarbons: an Environmental Perspective, Microbiological Reviews 45(1): 180-209.

Atlas RM. 1993. Extraction of DNA from soils and sediments. In: Kemp PF, Sherr FF, and Cole JJ (eds.) Handbook of Methods in Aquatic Microbial Ecology. Lewis Publishers, Boca Raton.

Atlas RM and Bartha R. 1993. Microbial Ecology: Fundamentals and Applications, Third edition. The Benjamin/Cummings Publishing Company, Inc.

Atlas RM, Horowitz A, Krichevsky M, and Bej AK. 1991. Response of microbial populations to environmental disturbance. Microbial Ecology 22: 249-256. 
Atlas RM. 1984. Use of microbial diversity measurements to assess environmental stress, "In: Current Perspectives in Microbial Ecology, Proceedings of the Third International Symposium on Microbial Ecology. Washington, D.C. : American Society for Microbiology, 540-545.

Ausubel FM (ed.). 1994. Current Protocols in Molecular Biology. Greene Publishing Associates and Wiley-Interscience; J. Wiley, New York.

Avaniss-Aghajani E, Jones K, Chapman D, and Brunk C. 1994. A molecular technique for identification of bacteria using small subunit ribosomal RNA sequences. BioTechniques 17(1): 144-149.

Axelrood PE, Chow ML, Radomski CC, McDermott JM, and Davies J. 2002. Molecular characterization of bacterial diversity from British Columbia forest soils subjected to disturbance. Canadian Journal of Microbiology 48: 655-674.

Balkwill DL, Fredrickson JK, and Thomas JM. 1989. Vertical and horizontal variation in the physiological diversity of the aerobic chemoheterotrophic bacterial microflora in deep southeast coastal plain subsurface sediments. Applied and Environmental Microbiology 55: 1058-1065.

Balkwill DL. 1990. Deep aquifer microorganisms. In: Labeda DP, Isolation of biotechnological organisms from nature. McGraw-Hill, New York.

Banfield JF and Nealson KH. 1997. Interactions Between Microbes and Minerals. In: Banfield JF and Nealson KH (Eds.) Geomicrobiology. Mineralogical Society of America. Washington DC

Barns SM, Fundyga RE, Jeffries MW, and Pace NR. 1994. Remarkable archaeal diversity detected in a Yellowstone National Park hot spring environment. Proceedings of the National Academy of Sciences of the United States of America 91: 1609-1613.

Barr TC. 1968. Cave ecology and the evolution of troglobites. Evolutionary Biology 2: $35-102$.

Benlloch S, Rodriguez-Valera F, and Martinez-Murcia AJ. 1995. Bacterial diversity in two coastal lagoons deduced from 16S rDNA PCR amplification and partial sequencing. FEMS Microbiological Ecology 18: 267-280.

Berthelet M, Whyte LG, and Greer CW. 1996. Rapid, direct extraction of DNA from soils for PCR analysis using polyvinylpolypyrrolidone spin columns. FEMS Microbiology Letters 138: 17-22. 
Bickley J, Short JK, McDowell DG, and Parkes HC. 1996. Polymerase chain reaction (PCR) detection of Listeria monocytogenes in diluted milk and reversal of PCR inhibition caused by calcium ions. Letters in Applied Microbiology 22: $153-158$.

Bigelow J. 1998. Biomes: the Promise of Cave-Dwelling Microbes. NSS News 56: $145-53$.

Bone TL and Balkwill DL. 1988. Morphological and Cultural Comparison of Microorganisms in Surface Soil and Subsurface Sediments at a Pristine Study Site in Oklahoma, Microbial Ecology 16: 49-64.

Borneman J, Skroch PW, O'Sullivan KM, Plus JA, Rumjanek NG, Jansen JL, Nienhuis J, and Triplett EW. 1996. Molecular microbial diversity of an agricultural soil in Wisconsin. Applied and Environmental Microbiology 62: 1935-1943.

Borneman J and Triplett EW. 1997. Molecular microbial diversity in soils from eastern Amazonia: Evidence for unusual microorganisms and microbial population shifts associated with deforestation. Applied and Environmental Microbiology 63: 26472653.

Borowsky RL and Vidthayanon C. 2001. Nucleotide diversity in populations of balitorid cave fishes from Thailand. Molecular Ecology 10: 2799-2805.

Boston PJ, Ivanov MVV, and McKay CP. 1992. On the possibility of chemosynthetic ecosystems in subsurface habitats on Mars. Icarus 95: 300-308.

Boston PJ. 1999. A bit of peace and quiet: The microbes of Lechuguilla. NSS News 57(8): 237-238.

Boston PJ. 2001. Microbes, Minerals, and Mars: The NASA-Cave Connection. NSS News 59(3): p. 70.

Boston PJ, Soroka DS, Kleina LG, Lavoie KH, Spilde MN, Northup DE, and Hose LD. 2000. A garden inside out; microbial mats in springs, wall muds, and ceiling formations of a sulfur-dominated cave, Cueva de Villa Luz, Tabasco, Mexico. Journal of Cave and Karst Studies 62(3):198.

Britten RJ and Davidson EH. 1976. Studies on nucleic acid reassociation kinetics: Empirical equations describing DNA reassociation. Proceedings of the National Academy of Sciences of the United States of America 73(2): 415-419.

Bruce KD, Hiorns WD, Hobman JL, Osborn AM, Strike P, and Ritchie DA. 1992. Amplification of DNA from native populations of soil bacteria by using the polymerase chain reaction. Applied and Environmental Microbiology 58: 3413- 
Bruggemann J, Chang YJ, Kowalchuk GA, Macnaughton SJ, Itavaara M, Kline E, White DC, and Stephen JR. 2000. Dispelling the myths: How well do multiple competitive PCR products from 16S rDNA reflect the structures of microbial communities? BioRadiations 104: 32-34.

Caldwell ED. 1991. Limnological survey of cavern pools. Report to Carlsbad Caverns National Park p.31.

Canaveras JC, Hoyos M, Sanchez-Moral S, Sanz-Rubio E, Bedoya J, Soler V, Groth I, Schumann P, Laiz L, Gonzalel I, and Saiz-Jimenez C. 1999. Microbial communities associated with hydromagnesite and needle-fiber aragonite deposits in a karstic cave (Alamira, Northern Spain). Geomicrobiology Journal 16: 9-25.

Chabrerie O, Laval K, Puget P, Desaire S, and Alard D. 2003. Relationship between plant and soil microbial communities along a successional gradient in chalk grassland in north-western France. Applied Soil Ecology In Press

Chandler DP, Li S, Spadoni CM, Drake GR, Balkwill DL, Fredrickson JK, and Brockman FJ. 1997. A molecular comparison of culturable aerobic heterotrophic bacteria and $16 \mathrm{~S}$ rDNA clones derived from a deep subsurface sediment. FEMS Microbiology Ecology 23: 131-144.

Chess DL. 1987. Comparisons of microbiology and selected anions for surface and subsurface stream waters for the Aqua Spring watershed of Burnsville Cove, Virginia. M.S. Thesis, Pennsylvania State University.

Choi BK, Paster BJ, Dewhirst FE and Gobel UB. 1994. Diversity of cultivable and uncultivable oral spirochetes from a patient with severe destructive periodontitis. Infectious Immunology 62(5): 1889-1895.

Clegg CD, Ritz K, and Griffiths BS. 1998. Broad-scale analysis of soil microbial community DNA from upland grasslands. Antonie van Leeuwenhoek 3: 9-14.

Coates JD, Cole KS, Chakraborty R, O'Connor SM, and Achenbach LA. 2002. Diversity and ubiquity of bacteria capable of utilizing humic substances as electron donors for anaerobic respiration. Applied and Environmental Microbiology 68: 24452452.

Coghlan A. 1999. Enforcing Europe's tough food laws could depend on a very precise DNA kit. New Scientist 27 March.

Combie J and Runnion K. 1996. Looking for diversity of Yellowstone extremophiles. Journal of Industrial Microbiology 17: 214-218.

Connell JH and Orias E. 1964. The Ecological Regulation of Species Diversity. The American Naturalist 98(903): 399-414. 
Connell, J. H. 1978. Diversity in tropical rainforests and coral reefs. Science 199: 13021310.

Culver D. 1970. Analysis of Simple Cave Communities I. Caves as Islands. Evolution 24(2): 463-474.

Culver D. 1982. Cave Life: Ecology \& Evolution. Harvard University Press. Cambridge, Massachusetts

Culver DC and Sket B. 2000. Hotspots of subterranean biodiversity in caves and wells. Journal of Cave and Karst Studies 62: 11-17.

Cunningham KI, Northup DE, Pollastro RM, Wright WG, and LaRock EJ. 1995. Bacteria, fungi, and biokarst in Lechuguilla Cave, Carlsbad Caverns National Park, New Mexico. Environmental Geology 25: 2-8.

Currens J. 2001. Karst Dye Traces. Kentucky Geological Survey, Lexington, KY

Currens JC. 2002. Kentucky is Karst Country: What you should know about sinkholes and springs. Kentucky Geological Survey, Information Circular 4, Series XII, Lexington, KY.

Danielli HMC and Edington MA. 1983. Bacterial calcification in limestone caves. Geomicrobiology Journal 3: 1-16.

Dang $\mathrm{H}$ and Lovell CR. 2000. Bacterial primary colonization and early succession on surfaces in marine waters as determined by amplified rRNA gene restriction analysis and sequence analysis of $16 \mathrm{~S}$ rRNA genes. Applied and Environmental Microbiology 66: 467-475.

Deharveng L. 2002. Cave fauna of the oriental region. XVI International Symposium of Biospeleology

Drake JJ and Harmon RS. 1973. Hydrochemical Environments of Carbonate Terrains. Water Resources Research 9: 949-957

Drake M, Small CL, Spence KD, and Swanson BG. 1996. Rapid detection and identification of Lactobacillus spp. in dairy products by using the polymerase chain reaction. Journal of Food Protection 59: 1031-1036

Dunbar J, Takala S, Barns SM, Davis JA, and Kuske CR. 1999. Levels of bacterial community diversity in four arid soils compared by cultivation and $16 \mathrm{~S}$ rRNA gene cloning. Applied and Environmental Microbiology 65: 1662-1669.

Dunbar J, Barns S, Ticknor LO, and Kuske, CR. 2002. Empirical and theoretical bacterial diversity in four Arizona soils. Applied and Environmental Microbiology 68: 3035-3045. 
Elliott WR. 1992a. Caves, endangered species, and biodiversity. American Caves Spring/Summer, p. 19.

Elliott WR. 1992b. Fire ants invade Texas caves. American Caves Winter, p. 13.

Elliott W and Reddell J. 1989. The status and range of five endangered arthropods from caves in the Austin, Texas, region. A report on a study supported by the Texas Parks and Wildlife Department and the Texas Natural Conservancy for the Austin Regional Habitat Conservation Plan. 100 pp.

Engel AS. 1999. Geomicrobiology of sulfidic karst systems. Masters thesis, University of Cincinnati, $88 \mathrm{p}$.

Engel AS, Lee N, Porter ML, Stern LA, Bennett PC, and Wagner M. 2003. Filamentous "Epsilonproteobacteria" dominate microbial mats from sulfidic cave springs. Applied and Environmental Microbiology 69: 5503-5511.

Engel AS, Porter ML, Kinkle BK, and Kane TC. 2001. Ecological assessment and geological significance of microbial communities from Cesspool Cave, Virginia. Geomicrobiology Journal 18: 259-274.

Farrelly V, Rainey FA, and Stackebrandt E. 1995. Effect of genome size and rrn gene copy number on PCR amplification of 16S rRNA genes from a mixture of bacterial species. Applied and Environmental Microbiology 61: 2798-2801.

Felske A, Akkermans ADL, and DeVos WM. 1998. Quantification of 16S rRNAs in complex bacterial communities by multiple competitive reverse transcription-PCR in temperature gradient gel electrophoresis fingerprints, Applied and Environmental Microbiology 64: 4581-4587.

Forbes JR. 2000. Geochemistry of Carlsbad Cavern pool waters, Guadalupe Mountains, New Mexico. Journal of Cave and Karst Studies 62: 127-134.

Ford D. 2000. Chapter 5.3 Speleogenesis under confined settings. In: Speleogenesis: Evolution of karst aquifers. Klimchouk A, Ford D, Palmer A, and Dreybodt W (eds). National Speleological Society, Inc. Huntsville

Ford DC and Williams PW. 1989. Karst geomorphology and hydrology. Chapman and Hall, London, 601 pp.

Fowler R, Breeding L, Ovesen J, Groves C, and Sahi S. 2001. A DNA Fingerprinting Technique to Survey Microbial Diversity in Caves. 2001 National Cave and Karst Management Symposium

Fox GE, Pechman KR, and Woese CR. 1977. Comparative cataloging of 16S ribosomal ribonucleic acid: molecular approach to prokaryotic systematics. International Journal of Systematic Bacteriology 27: 44-57. 
Frostegard A, Courtois S, Ramisse V, Clerc S, Bernillon D, LeGall F, Jeannin P, Nesme X, and Simonet P. 1999. Quantification of bias related to the extraction directly from soils. Applied and Environmental Microbiology 65: 5409-5420.

Fuhrman JA, McCallum K, Davis AA. 1993. Phylogenetic diversity of subsurface marine microbial communities from the Atlantic and Pacific Oceans. Applied and Environmental Microbiology 59: 1294-1302.

Garcia-Martinez J, Acinas SG, Anton AI, and Rodrigues-Valera F. 1999. Use of the 16S-23S ribosomal genes spacer region in studies of prokaryotic diversity. Journal of Microbiological Methods 36: 55-64.

George AI. 1985. Caves in Kentucky. In: Caves and Karst of Kentucky, Special Publication 12, Series XI, Kentucky Geological Survey, University of Kentucky

Ghiorse WC and Balkwill. 1985. Microbiological Characterization of Subsurface Environments. In: Ground Water Quality, Ward GW and McCarty PL (eds.). John Wiley \& Sons, Inc., New York.

Gillieson D. 1996. Caves: Processes, Development, Management. Blackwell Publishers Ltd., Cambridge.

Giovannoni SJ, Britschgi TB, Moyer CL, and Field KG. 1990. Genetic diversity in Sargasso Sea bacterioplankton. Nature 345: 60-63.

Gounot AM. 1994. Microbial Ecology of Groundwaters. In: Groundwater Ecology. Gibert J, Danielopol DL, and Stanford JA. Academic Press, Inc., San Diego.

Greenberg AE, Clesceri LS, and Eaton AD (eds.). 1992. Standard Methods for the Examination of Water and Wastewater, $18^{\text {th }}$ ed., American Public Health Association, American Water Works Association, Water Environment Federation, Washington DC.

Griffiths BS, Ritz K, and Glover LA. 1996. Broad-scale approaches to the determination of soil microbial community structure: Application of the community DNA hybridization technique. Microbial Ecology 31: 269-280.

Groth I and Saiz-Jimenez C. 1999. Actinomycetes in hypogean environments. Geomicrobiology Journal 16: 1-8.

Groth I, Vettermann R, Schuetze B, Schumann P, and Saiz-Jimenez C. 1999. Actinomycetes in karstic caves of northern Spain (Altamira and Tito Bustillo). Journal of Microbiological Methods 36: 115-122.

Guthrie JN, Moriarty DJW, and Blackall LL. 2000. DNA extraction from coral reef sediment bacteria for the polymerase chain reaction. Journal of Microbiological Methods 43: 73-80. 
Hastings R, Saunders J, and McCarthy A. 2000. Monitoring bacterial genetic diversity in a freshwater lake using temporal temperature gradient gel electrophoresis and DNA sequence analysis. BioRadiations 104: 11-12.

Herrick JB, Madsen EL, Batt CA, and Ghiorse WC. 1993. Polymerase chain reaction amplification of naphthalene-catabolic and $16 \mathrm{~S}$ rRNA gene sequences from indigenous sediment bacteria. Applied and Environmental Microbiology 59: 687-694.

Heyndrickx M, Vauterin L, Vandamme P, Kersters K, and DeVos P. 1996. Applicability of combined amplified ribosomal DNA restriction analysis (ARDRA) patterns in bacterial phylogeny and taxonomy. Journal of Microbiological Methods 26: $247-259$.

Hill CA. 1987. Geology of Carlsbad Cavern and other caves in the Guadalupe Mountains, New Mexico and Texas. New Mexico Bureau of Mines and Mineral Resources Bulletin 117: $150 \mathrm{pp}$.

Hill CA. 2000. Overview of the geologic history of cave development in the Guadalupe Mountains, New Mexico. Journal of Cave and Karst Studies 62(2): 60-71.

Hill C and Forti P. 1997. Cave Minerals of the World, (2nd ed.). National Speleological Society, Huntsville, AL, 463 p.

Hoffman L. 1989. Algae of Terrestrial Habitats. The Botanical Review 55: 78-91.

Holben WE, Jansson JK, Chelm BK, and Tiedje JM. 1988. DNA probe method for the detection of specific microorganisms in the soil bacterial community. Applied and Environmental Microbiology 54: 703-711.

Holsinger JR. 1974. Systematics of the subterranean amphipod genus Stygobromus (Gammaridae), Part I: Species of the western United States. Smithsonian Contributions to Zoology 160.

Holsinger JR. 1988. Troglobites: the evolution of cave-dwelling organisms. American Scientist 76: 146-151.

Horowitz A, Krichevsky MI, and Atlas RM. 1983. Characteristics and diversity of subarctic marine oligotrophic, stenoheterotrophic, and euryheterotrophic bacterial populations. Canadian Journal of Microbiology 29: 527-535.

Howarth FG. 1983. The conservation of Hawaii's cave resources. The Newsletter of Cave Conservation and Management 2(1-2): 19-23.

Hugenholtz P, Goebel BM, and Pace NR. 1998. Impact of culture-independent studies on the emerging phylogenetic view of bacterial diversity: A Minireview. Journal of Bacteriology 180(18): 4765-4774. 
Hughes MS, Beck L-A, and Skuce RA. 1994. Identification and elimination of DNA sequences in Taq DNA polymerase. Journal of Clinical Microbiology 32: 20072008 .

Huston M. 1979. A general hypothesis of species diversity. American Naturalist 113: $81-101$.

Hwang EY, Harry JL, and Poindexter JS. 2000. Use of dialysis to prepare bacterial DNA suitable as PCR template. BioTechniques 28: 1072-1075.

Jacobsen S and Rasmussen OS. 1992. Applied and Environmental Microbiology 58: 2458-2462.

Jagnow DH, Hill CA, Davis DG, DuChene HR, Cunningham KI, Northup DE, and Queen JM. 2000. History of the sulfuric acid theory of speleogenesis in the Guadalupe Mountains, New Mexico. Journal of Cave and Karst Studies 62(2): 54-59.

Jimenez L. 1990. Molecular analysis of deep-subsurface bacteria. Applied and Environmental Microbiology 56: 2108-2113.

Jones TG, Pearson WD, and Boston CH Jr. 1997. Community Structure of selected subterranean aquatic habitats in and around Mammoth Cave National Park.

Kawai M, Matsutera E, Kanda H, Yamaguchi N, Tani K, and Nasu M. 2002. 16S ribosomal DNA-based analysis of bacterial diversity in purified water used in pharmaceutical manufacturing processes by PCR and denaturing gradient gel electrophoresis. Applied and Environmental Microbiology 68: 699-704.

Kentucky Waterways Alliance. 1988. Splashing in Kentucky: An educator's guide to non-point source water pollution. Compiled by Kathy Neely. Published by Kentucky Waterways Alliance and the Kentucky Division of Water, Nonpoint Source Section.

Kepner RL Jr and Pratt JR. 1993. Use of fluorochromes for direct enumeration of total bacteria in environmental samples: Past and present. Microbiological Reviews 58(4): 603-615.

Kerr RA. 1997. Life Goes to Extremes in the Deep Earth-and Elsewhere? Science 276: 703-704.

Khizhnyak SV, Tausheva IV, Berezikova AA, Nesterenko EV, and Rogozin DY. 2003. Psychrophilic and phychrotolerant heterotrophic microorganisms of middle Siberian karst cavities. Russian Journal of Ecology 34(4): 231-235.

Kirchman D, Sigda J, Kapuscinski R, and Mitchell R. 1982. Statistical analysis of the direct count method for enumerating bacteria. Applied and Environmental Microbiology 44: 376-382. 
Klappenbach JA, Saxman PR, Cole JR, and Schmidt TM. 2001. The ribosomal RNA operon copy number database. Nucleic Acids Research 29(1): 181-184.

Konet DS, Mezencio JMS, Babcock G, and Brown F. 2000. Inhibitors in RT-PCR in serum. Journal of Virological Methods 84: 95-98.

Kopczynski ED, Bateson MM, and Ward DM. 1994. Recogntion of chimeric smallsubunit ribosomal DNAs composed of genes from uncultivated microorganisms. Applied and Environmental Microbiology 60: 746-748.

Krajick K. 2001. Cave biologists unearth buried treasure. Science 293: 2378-2381.

Krsek M and Wellington EMH. 1999. Comparison of different methods for the isolation of total community DNA from soil. Journal of Microbiological Methods 39(1): 1-16.

Kuske CR, Banton KL, Adorada DL, Stark PC, Hill KK, and Jackson PJ. 1998. Small-scale DNA sample preparation method for field PCR detection of microbial cells and spores in soil. Applied and Environmental Microbiology 64(7): 24632472 .

Kuske CR, Barns SM, and Busch JD. 1997. Diverse uncultivated bacterial groups from soils of the arid southwestern United States that are present in many geographic regions. Applied and Environmental Microbiology 63: 3614-3621.

Laing C, Carmody GR, and Peck SB. 1976. Population genetics and evolutionary biology of the cave beetle Ptomaphagus hirtus. Evolution 30(3): 484-498.

Laiz L, Gonzalez JM, and Saiz-Jimenez C. 2002. Microbial communities in caves: Ecology, physiology and effects on paleolithic paintings.

Laiz L, Groth I, Gonzalez I, and Saiz-Jimenez C. 1999. Microbiological study of the dripping waters in Altamira cave (Santillana del Mar, Spain). Journal of Microbiological Methods 36: 129-138.

Laiz L, Groth I, SchumannP, Zezza F, Felske A, Hermosin B, Saiz-Jimenez C. 2000. Microbiology of the stalactites from Grotta dei Cervi, Porto Badisco, Italy. International Microbiology 3: 25-30.

Lavoie K, Northup D and Boston P. 2000. Sight Unseen: Microbes in Caves. NSS News (March) 68-69.

Leeflang P and Smit E. 1997. Use of the expand PCR system to amplify the $16 \mathrm{~S}$ ribosomal genes for the characterization of bacterial communities in soil. Biochemica 1: 16-18. 
Leff LG. 1994. Stream bacterial ecology: A neglected field? ASM News 60(3): $135-138$.

Leff LG, Dana JR, McArthur JV, and Shimkets LJ. 1995. Comparison of methods of DNA extraction from stream sediments. Applied and Environmental Microbiology 61(3): 1141-1143.

Liesack W, Weyland H, and Stackebrandt E. 1991. Potential risks of gene amplification by PCR as determined by $16 \mathrm{~S}$ rDNA analysis of a mixed-culture of strict barophilic bacteria. Microbial Ecology 21: 191-198.

Lenski RE. 1995. Molecules are more than markers: New directions in molecular microbial ecology. Molecular Ecology 4(5): 643-651.

Lewin B. 1994. Genes V. Oxford University Press, Inc. New York

Lewis JJ. 1993. Life returns to Hidden River Cave: The rebirth of a destroyed cave system. NSS News July: 208-213.

Lewis JJ, Lewis TM, and Eckstein J. 1983. A biological reconnaissance of a polluted cave stream: The Hidden River Groundwater Basin. Cave Research Foundation Annual Report 1982 p. 9-10.

Liesack W, Weyland H, and Stackebrandt E. 1991. Potential risks of gene amplification by PCR as determined by $16 \mathrm{~S}$ rDNA analysis of a mixed-culture of strict barophilic bacteria. Microbial Ecology 21: 191-198.

Liu WT, Marsh TL, Cheng H, and Forney LJ. 1997. Characterization of microbial diversity by determining terminal restriction fragment length polymorphisms of genes encoding 16S rRNA. Applied and Environmental Microbiology 63: 4516-4522.

Ludwig W and Schleifer KH. 1994. Bacterial phylogeny based on 16S and 23S rRNA sequence analysis. FEMS Microbiology Review 15: 155-173.

MacArthur RH. 1955. Fluctuations of animal populations and a measure of community stability. Ecology 36: 533-536.

MacGillivray EW, Grime JP, Band SR, Booth RE, Campbell B, Hendry GAF, Hillier SH, Hodgson JG, Hunt R, Jalili A, Mackey JML, Mowforth MA, Neal AM, Reader R, Rorison IH, Spencer RE, Thompson K and Thorpe PC. 1995. Testing predictions of the resistance and resilience of vegetation subjected to extreme events. Functional Ecology 9: 640-649. 
Marchesi JR, Sato T, Weightman AJ, Martin TA, Fry JC, Hiom SJ and Wade WG. 1998. Design and evaluation of useful bacterium specific PCR primers that amplify genes coding for bacterial 16S rRNA. Applied and Environmental Microbiology 64(2): 795-799.

Margalef R. 1963. On certain unifying principles in ecology. American Naturalist 97: 357-374.

Marsh TL, Saxman P, Cole J, and Tiedje J. 2000. Terminal Restriction Fragment Length Polymorphism analysis program, a web-based research tool for microbial community analysis. Applied and Environmental Microbiology 66(8): 3616-3620.

Martin-Laurent F, Philippot L, Hallet S, Chaussod R, Germon JC, Soulas G, and Catroux G. 2001. DNA extraction from soils: Old bias for new microbial diversity analysis methods. Applied and Environmental Microbiology 67: 2354-2359.

Martinez-Murcia AJ, Acinas SG, and Rodrigues-Valera F. 1995. Evaluation of prokaryotic diversity by restriction digestion of $16 \mathrm{~S}$ rDNA directly amplified from hypersaline environments. FEMS Microbiology Ecology 17(4): 247-255.

Mayer J. 1999. Spatial and temporal variation of groundwater chemistry in Pettyjohns Cave, northwest Georgia, USA. Journal of Cave and Karst Studies 61(3): 131-138.

McArthur JV, Leff LG, and Smith MH. 1992. Genetic diversity of bacteria along a stream continuum. Journal of North American Benthological Society 11(3): 269-277.

McCaig AE, Glover LA, and Prosser JI. 2001. Numerical analysis of grassland bacterial community structure under different land management regimens by using $16 \mathrm{~S}$ ribosomal DNA sequence data and denaturing gradient gel electrophoresis banding patterns. Applied and Environmental Microbiology 67(10): 4554-4559.

Meiman J and Ryan M. 1993. The Echo River-Turnhole Bend overflow route. CRF Newsletter 21(1): 1, 16-18.

Meiman J, Groves CG, and Herstein S. 2001. In-cave dye tracing and drainage divides in the Mammoth Cave karst aquifer, Kentucky. U.S. Geological Survey Karst Interest Group Proceedings, St. Petersburg, FL 179-185.

Miller DN, Bryant JE, Madsen EL, and Ghiorse WC. 1999. Evaluation and optimization of DNA extraction and purification procedures for soil and sediment samples. Applied and Environmental Microbiology 65: 4715-4724.

Moffett BF, Walsh KA, Harris JA, and Hill TCJ. 2000. Analysis of bacterial community structure using 16S rDNA analysis. Anaerobe 6: 129-131. 
Muyzer GA, de Waal EC, and Uitterlinden AG. 1993. Profiling of microbial populations by denaturing gradient gel electrophoresis analysis of polymerase chain reaction amplified genes coding for 16S rRNA. Applied and Environmental Microbiology 59: 695-700.

Nadis S. 1997. Looking Inside Earth for Life on Mars. Technology Review, 100(8): 114.

Nakatsu CH, Torsvik V, and Ovreas L. 2000. Soil community analysis using DGGE of $16 \mathrm{~S}$ rDNA polymerase chain reaction products. Soil Science Society of America Journal 64: 1382-1388.

Newman DK and Banfield JF. 1997. How Molecular-Scale Interactions Underpin Biogeochemical Systems. In: Banfield JF and Nealson KH (Eds.) Geomicrobiology. Mineralogical Society of America. Washington DC

Northup D, Angert E, Reysenbach AL, Peek A, and Pace N. year? Microbial Communities in Sulphur River, Parker Cave: A Molecular Phylogenetic Study. Conservation and Protection of the Biota of Karst vol? page?

Northup DE, Dahm CN, Melim LA, Spilde MN, Crossey LJ, Lavoie KH, Mallory LM, Boston PJ, Cunningham KI, and Barns SM. 2000. Evidence for geomicrobiological interactions in Guadalupe caves. Journal of Cave and Karst Studies 62(2): 80-90.

Nübel U, Engelen B, Felske A, Snaidr J, Wieshuber A, Amann RI, Ludwig W, and Backhaus H. 1996. Sequence heterogeneities of genes encoding 16S rRNAs in Paenibacillus polymyxa detected by temperature gradient gel electrophoresis. Journal of Bacteriology 178: 5636-5643.

Nusslein K and Tiedje JM. 1999. Soil bacterial community shift correlated with change from forest to pasture vegetation in a tropical soil. Applied and Environmental Microbiology 65: 3622-3626.

O'Donnell AG, Goodfellow M, and Hawksworth DL. 1994. Theoretical and practical aspects of the quantification of biodiversity among microorganisms. Philosophical Transactions of the Royal Society, London 345: 65-73.

Ogram, A. 1998. Isolation of nucleic acids from environmental samples. In: Techniques in Microbial Ecology, Burlage RS, Atlas R, Stahl, D, Geesey G, and Sayler G (eds.) Oxford University Press, New York, N.Y.

Ogram A. 2000. Soil molecular microbial ecology at age 20: Methodological challenges for the future. Soil Biology \& Biochemistry 32: 1499-1504.

Ogram AV, Sayler GS, and Barkay T. 1988. The extraction and purification of microbial DNA from sediments. Journal of Microbiological Methods 7: 57-66. 
Ogunjimi AA and Choudary PV. 1999. Adsorption of endogenous polyphenols relieves the inhibition by fruit juices and fresh product of immuno-PCR detection of Escherichia coli 0157:H7. FEMS Immunology and Medical Microbiology 23: 213-220.

Orr WL. 1977. Geologic and geochemical controls on the distribution of hydrogen sulfide in natural gas. In: Advances in Organic Geochemistry, Campos R and Goni J (eds.), Madrid, Empressa nacional adaro de investigaciones mineras, p. 571-597.

Ovreas L and Torsvik V. 1998. Microbial diversity and community structure in two different agricultural soil communities. Microbial Ecology 36: 303-315.

Pace NR. 1997. A molecular view of microbial diversity and the biosphere. Science 276: 734-740.

Pace NR, Stahl DA, Lane DJ, and Olsen GJ. 1986. The analysis of natural microbial populations by ribosomal RNA sequences. Advanced Microbial Ecology 9: 1-55.

Palmer AN. 1991. Origin and morphology of limestone caves. Geological Society of America Bulletin 103: 1-21.

Pearson WD. 2000. A Field Trip to the Sinking Creek System of Breckinridge County, Kentucky. Kentucky Speleofest 2000 Guidebook; Inner Space Exploration 71-81.

Peck SB. 1976. The effect of cave entrances on the distribution of cave-inhabiting terrestrial arthropods. International Journal of Speleology 8: 309-321.

Peck S. 1998. A summary of diversity and distribution of the obligate cave-inhabiting faunas of the United States and Canada. Journal of Cave and Karst Studies 60(1): $18-26$.

Pedersen K, Arlinger J, Ekendahl S, and Hallbeck L. 1996. 16S rRNA gene diversity of attached and unattached bacteria in boreholes along the access tunnel to the Aspo hard rock laboratory, Sweden. FEMS Microbiological Ecology 19: 249-262.

Picard C, Ponsonnet C, Paget E, Nesme X, and Simonet P. 1992. Detection and enumeration of bacterial in soil by direct DNA extraction and polymerase chain reaction. Applied and Environmental Microbiology 58: 2717-2722.

Poiner HN, Hofrieter M, Spaulding WG, Martin PS, Stankiewicz A, Bland H, Evershed RP, Possnert G, and Paabo S. 1998. Molecular Coproscopy: Dung and diet of the extinct ground sloth Norhrotheriops shastensis. Science 281: 402-406.

Poulson TL. 1963. Cave adaptation in amblyopsis fishes. The American Midland Naturalist 70(2):257-290. 
Poulson TL. 1997. The Mammoth Cave Tour. In: Conservation and Protection of the Biota of Karst, Symposium at Nashville, Tennessee, February 13-16, 1997, Sasowsky ID, Fong DW, and White EL (eds.), Karst Waters Institute, Charles Town, West Virginia, Special Publication 3, p.113-117.

Poulson TL and White WB. 1969. The Cave Environment. Science 165: 971-981.

Pukall R, Brambilla E, and Stackebrandt E. 1998. Automated fragment length analysis of fluorescently-labeled 16S rDNA after digestion with 4-base cutting restriction enzymes. Journal of Microbiological Methods 32: 55-63.

Purvis A and Hector A. 2000. Getting the measure of biodiversity. Nature 405: 212-219.

Pye VI and Patrick R. 1983. Ground Water Contamination in the United States. Science 221: 713-718.

Quinlan JF, Ewers RO, and Ray JA. 1983. Groundwater hydrology and Geomorphology of the Mammoth Cave region, Kentucky. Geological Society of Kentucky Field Trip Guide.

Quinlan JF and Ray JA. 1989. Groundwater basins in the Mammoth Cave region, Kentucky. Friends of the Karst Occasional Publication no. 2, map.

Rainey FA, Ward N, Sly LI, and Stackebrandt E. 1994. Dependence on the taxon composition of clone libraries for PCR amplified, naturally occurring $16 \mathrm{~S}$ rDNA, on the primer pair and the cloning system used. Experientia 50: 796-797.

Rainey FA, Ray KE, and Ward-Rainey N. The camels of the prokaryotic world. Ecology and Diversity of Extremophiles

Ranjard L, Poly F, and Nazaret S. 2000. Monitoring complex bacterial communities using culture-independent molecular techniques: application to soil environment. Research Microbiology 151: 167-177.

Reysenbach A, Giver LJ, Wickham GS, and Pace NR. 1992. Differential amplification of rRNA genes by polymerase chain reaction. Environmental Microbiology 58: 3417-3418.

Rheims H, Rainey FA, and Stackebrandt E. 1996. A molecular approach to search for diversity among bacteria in the environment. Journal of Industrial Microbiology 17: $159-169$.

Ritz K, Griffiths BS, Torsvik VL, and Hendriksen NB. 1997. Analysis of soil and bacterioplankton community DNA by melting profiles and reassociation kinetics. FEMS Microbiology Letters 149(2): 151-156. 
Rochelle PA, Cragg BA, Fry JC, Parkes RJ, and Weightman AJ. 1994. Effect of sample handling on estimation of bacterial diversity in marine sediments by $16 \mathrm{~S}$ rRNA gene sequence analysis. FEMS Microbiology Ecology 15: 215-226.

Rousseaux S, Hartmann A, Rouard N, and Soulas G. 2003. A simplified procedure for terminal restriction fragment length polymorphism analysis of the soil bacterial community to study the effects of pesticides on the soil microflora using 4,6dinitroorthocresol as a test case.

Rusterholz KJ and Mallory LM. 1994. Density, activity, and density of bacteria indigenous to a karstic aquifer. Microbial Ecology 28:79-99.

Ryan M and Meiman J. 1996. An examination of short-term variations in water quality at a karst spring in Kentucky. Ground Water 34(1): 23-30.

Sambrook J, Fritsch EF, and Maniatis T. 1989. Molecular Cloning; A Laboratory Manual, $2^{\text {nd }}$ ed., Cold Spring Harbor Laboratory Press

Sandaa RA, Torsvik V, and Enger O. 2001. Influence of long-term heavy-metal contamination on microbial communities in soil. Soil Biology and Biochemistry 33(3): 287-295.

Sandaa R, Torsvik V, Enger O, Daae FL, Castberg T, and Hahn D. 1999. Analysis of bacterial communities in heavy metal-contaminated soils at different levels of resolution. FEMS Microbiology Ecology 30: 237-251.

Santini JM, Sly LI, Schnagl RD, and Macy JM. 2000. A new chemolithoautotrophic arsenite-oxidizing bacterium isolated from a gold mine: Phylogenic, physiological, and preliminary biochemical studies. Applied and Environmental Microbiology 66: 92-97.

Sarbu SM, Kane TC, and Kinkle BK. 1996. A chemoautotrophically based cave ecosystem. Science 272: 1953-1955.

Schleifer KH and Stackebrandt E. 1983. Molecular systematics of Prokaryotes. Annual Review of Microbiology 37: 143-187.

Schmidt TM, DeLong EF, and Pace NR. 1991. Analysis of a marine picoplankton community by $16 \mathrm{~S}$ rRNA gene cloning and sequencing. Journal of Bacteriology 173(14): 4371-4378.

Schwartz MW, Brigham CA, Hoeksema JD, Lyons KG, Mills MH, and vanMantgem PJ. 2000. Linking biodiversity to ecosystem function: implications for conservation ecology. Oecologia 122: 297-305. 
Sessitsch A, Weilharter A, Gerzabek MH, Kirchmann H, and Kandeler E. 2001. Microbial population structures in soil particle size fractions of a long-term fertilizer experiment. Applied and Environmental Microbiology 67: 4215-4224.

Sibley and Alquist. 1984. The phylogeny of the hominid primates as indicated by DNADNA hybridization. Journal of Molecular Evolution 20: 2-15.

Shively JM, van Keulen G, and Meijer WG. 1998. Something from almost nothing: Carbon dioxide fixation in chemoautotrophs. Annual Review of Microbiology 52: $191-230$.

Smalla K, Wachtendorf U, Heuer H, Liu WT, and Forney L. 1998. Analysis of BIOLOG GN substrate utilization patterns by microbial communities. Applied and Environmental Microbiology 64: 1220-1225.

Smit E, Leeflang P, Gommans S, van den Broek J, van Mil S, and Werners K. 2001. Diversity and seasonal fluctuations of the dominant members of the bacterial soil community in a wheat field as determined by cultivation and molecular methods. Applied and Environmental Microbiology 67: 2284-2291.

Smit E, Leeflang P, and Wernars K. 1997. Detection of shifts in microbial community structure and diversity in soil caused by copper contamination using amplified ribosomal DNA restriction analysis. FEMS Microbiology Ecology 23: 249-261.

Smith G. 2003. Carbon dioxide, caves, and you. Proceedings of the 21st Bienniel Australian Speleological Federation Conference 1997.

Sogin SJ, Sogin ML, and Woese CR. 1972. Phylogenetic measurement in prokaryotes by primary structural characterization. Journal of Molecular Evolution 1: 173-184.

Sorenson T. 1948. A method of establishing groups of equal amplitude in a plant society based on similarity of species content and its application to analysis of the vegetation on Danish commons. Biologiske skrifter Kongelige Danske Videnskabernes selskab 5: $1-34$.

Sousa WP. 1984. The Role of Disturbance in Natural Communities. Annual Review of Ecology Systematics 15: 353-391.

Stackebrandt E and Goebel BM. 1994. A place for DNA-DNA reassociation and 16S rRNA sequence analysis in the present species definition in bacteriology. International Journal of Systematic Bacteriology 44: 846-849.

Stackebrandt E, and Liesack W. 1993. Nucleic acids and classification, In: Handbook of new bacterial systematics, Goodfellow M and O'Donnell A (eds.). Academic Press, London. 
Stackebrandt E, Liesack W, and Goebel BM. 1993. Bacterial diversity in a soil sample from a subtropical Australian environment as determined by 16S rDNA analysis. FASEB Journal 7: 232-236.

Stahl DA. 1996. Molecular approaches for the measurement of density, diversity, and phylogeny. In: Manual of Environmental Microbiology, Hurst CJ (ed.), ASM Press Washington.

Steffan RJ and Atlas RM. 1988. DNA amplification to enhance detection of genetically engineered bacteria in environmental samples. Applied and Environmental Microbiology 54: 2185-2191.

Stevens TO, and McKinley JP. 1995. Lithoautotrophic microbial ecosystems in deep basalt aquifers. Science 270: 450-454.

Stotzky G. 1997. Soil as an environment for microbial life. In: Modern soil microbiology. Van Elsas JD, Trevors JT and Wellington EMH (eds.), 1-20. Marcel Dekker, New York.

Sundh, I. 1992. Biochemical composition of dissolved organic carbon derived from phytoplankton and used by heterotrophic bacteria. Applied and Environmental Microbiology 58: 2938-2947.

Suzuki MT and Giovannoni SJ. 1996. Bias caused by template annealing in the amplification of mixtures of $16 \mathrm{~S}$ rRNA genes by PCR. Applied and Environmental Microbiology 62: 625-630.

Suzuki MT, Rappe MS, Haimberger ZW, Winfield H, Adair N, Strobel J, and Giovannoni SJ. 1997. Bacterial diversity among small-subunit rRNA gene clones and cellular isolates from the same seawater sample. Applied and Environmental Microbiology 63: 983-989.

Tani K, Kurokawa K, and Nasu M. 1998. Development of a direct in situ PCR method for detection of specific bacteria in natural environments. Applied and Environmental Microbiology 64: 1536-1540.

Tate RL III. 1995. Soil Microbiology. John Wiley and Sons, Inc., New York, 398 p.

Taylor SJ and Webb DW. 2000. Groundwater chemistry and bacterial fauna of four large caves in Illinois' Salem Plateau. Journal of Cave and Karst Studies 62(1): 32

Tebbe CC, and Vahjen W. 1993. Interference of humic acids and DNA extracted directly from soil in detection and transformation of recombinant DNA from bacteria and a yeast. Applied and Environmental Microbiology 59: 2657-2665.

Thomas C. 1996. Bacterial diversity and the environment. TIBTECH vol 14, September, 327-329. 
Tiedje JM, Asuming-Brempong S, Nusslein K, Marsh TL, and Flynn SJ. 1999.

Opening the black box of soil microbial diversity. Applied Soil Ecology 13: 109-122.

Thomas DN and Dieckmann GS. 2002. Antarctic Sea Ice-a Habitat for Extremophiles. Science 295: 641-644.

Torsvik V, Daae FL, Sandaa R, and Ovreas L. 1998. Novel techniques for analyzing microbial diversity in natural and perturbed environments. Journal of Biotechnology 64(1):53-62.

Torsvik V, Goksoyr J, and Daae FL. 1990. High diversity of DNA of soil bacteria. Applied and Environmental Microbiology 56: 782-787.

Torsvik V and Ovreas L. 2002. Microbial diversity and function in soil: from genes to ecosystems. Current Opinion in Microbiology 5(3):240-245.

Torsvik V, Sorheim R, and Goksoyr J. 1996. Total bacterial diversity in soil and sediment communities-a review. Journal of Industrial Microbiology 17: 170-178.

Toth V. 1998. Spatial and temporal variations in the dissolved organic carbon concentrations in the vadose karst waters of Marengo Cave, Indiana. Journal of Cave and Karst Studies 60(3): 167-171.

Trevors JT. 1998. Bacterial biodiversity in soil with an emphasis on chemicallycontaminated soils. Water, Air, and Soil Pollution 101: 45-67.

Tsai YL and Olson BH. 1992. Rapid method for separation of bacterial DNA from humic substances in sediments for polymerase chain reaction. Applied and Environmental Microbiology 58: 2292-2295.

Tsai YL, Palmer CJ, and Sangermano LR. 1993. Detection of Escherichia coli in sewage and sludge by polymerase chain reaction. Applied and Environmental Microbiology 59: 353-357.

Turin HJ and Plummer MA. Lechuguilla cave pool chemistry, 1986-1999. 2000. Journal of Cave and Karst Studies 62(2): 135-143.

Turner S, DeLong EF, Giovannoni SJ, Olsen GJ, and Pace NR. Phylogenetic Analysis of Microorganisms and Natural Populations by Using rRNA Sequences. 390-401.

Ueda T, Suga Y, Yahiro N and Matsuguchi T. 1995. Remarkable N2-fixing bacterial diversity detected in riceroots by molecular evolutionary analysis of nifH gene sequences. Journal of Bacteriology 177: 1414-1417.

USDA-NASS. 1997. Kentucky State-level data, Land in Farms by County. Census of Agriculture Volume 1: Part 17, Chapter 1, United States Department of Agriculture, map. 
vanWaasbergen LG, Balkwill DL, Crocker FH, Bjornstad BN, and Miller RV. 2000. Genetic Diversity among Arthrobacter Species Collected across a Heterogeneous Series of Terrestrial Deep-Subsurface Sediments as Determined on the Basis of 16S rRNA and recA Gene Sequences. Applied and Environmental Microbiology 66(8): 3454-3463.

Vesper DJ, Loop CM, and White WB. 2001. Contaminant transport in karst aquifers. Theoretical and Applied Karstology 13-14: 101-111.

Wadowsky RM, Laus S, Libert T, States SJ, and Ehrlich GD. 1994. Inhibition of PCR-based assay for Bordetella pertussis by using calcium alginate fiber and aluminum shaft components of a nasopharyngeal swab. Journal of Clinical Microbiology 32(4): 1054-1057.

Waldman M and Shevah Y. 2000. Biological Diversity-An Overview. Water, Air, and Soil Pollution 123: 299-310.

Wallace AR. 1870. Contributions to the Theory of Natural Selection, 2nd ed., Macmillan. London, $384 \mathrm{pp}$.

Wallace AR. 1878. The colours of animals and plants. American Naturalist 11: 641-662.

Wang GCY and Wang Y. 1996. The frequency of chimeric molecules as a consequence of PCR co-amplification of $16 \mathrm{~S}$ rRNA genes from different bacterial species. Microbiology 142: 1107-1114.

Wardle DI, Kerr JB, McElroy CT, and Francis DR (Eds.). 1997. Ozone science: A Canadian perspective on the changing ozone layer. Rep. CARD 97-3, Environ. Canada Int., Downsview, Ontario, 19 pp.

Wayne LG, Brenner DJ, Colwell RR, Grimont PAD, Kandler O, Krichevsky MI, Moore LH, Moore WEC, Murray RGE, Stackebrandt E, Starr MP, and Truper HG. 1987. Report of the ad hoc committee on reconciliation of approaches to bacterial systematics. International Journal of Systematic Bacteriology 37: 463-464.

Ward DM, Bateson MM, Weller R, and Ruff-Roberts AL. 1992. Ribosomal RNA analysis of microorganisms as they occur in nature. Advancement of Microbial Ecology 12: 219-226.

Watve MG and Gangal RM. 1996. Problems in measuring bacterial diversity and a possible solution. Applied and Environmental Microbiology 62: 4299-4301.

Wenderoth DF and Reber HH. 1999. Correlation between structural diversity and catabolic versatility of metal-affected prototrophic bacteria in soil. Soil Biology \& Biochemistry 31: 345-352.

Went FW. 1969. Fungi associated with stalactite growth. Science 166: 385-386. 
White DC. 1995. Chemical Ecology: Possible linkage between macro-and microbial ecology. Oikos 74(2): 177-184.

White WB. 1997. Thermodynamic equilibrium, kinetics, activation barriers, and reaction mechanisms for chemical reactions in karst terrains. Environmental Geology 30: 46-58.

White WB and White E. 1989. Karst hydrology. In: Concepts from the Mammoth Cave area. 65-104.

Wilson EO. 1961. The nature of the taxon cycle in the Melanesian ant fauna. American Naturalist 95: 169-193.

Wilson IG. 1997. Inhibition and facilitation of nucleic acid amplification a minireview, Applied and Environmental Microbiology 63: 3741-3751.

Wilson IG, Cooper JE and Gilmour A. 1991. Detection of enterotoxigenic Staphylococcus aureus in dried skimmed milk: use of the polymerase chain reaction for amplification and detection of staphylococcal enterotoxin genes ent $B$ and entC1 the thermonuclease gene nuc. Applied and Environmental Microbiology 57: 1793-1798.

Wilson IG, Cooper JE and Gilmour A. 1993. Detection of enterotoxigenic microorganisms in foods by PCR. In: New techniques in food and beverage microbiology, Kroll RG, Gilmour A and Sussman M (eds.), Scientific Publishers, Blackwell Oxford, United Kingdon.

Wilson IG, Cooper JE and Gilmour A. 1994. Some factors inhibiting amplification of the Staphylococcus aureus enterotoxin $\mathrm{C}_{1}\left(\mathrm{sec}^{+}\right)$by PCR. International Journal of Food Microbiology 22: 55-62.

Wilson KH and Blitchington RB. 1996. Human colonic biota studied by ribosomal DNA sequence analysis. Applied and Environmental Microbiology 62: 2273-2278.

Wintzingerode FV, Gobel UB, and Stackebrandt E. 1997. Determination of microbial diversity in environmental samples: pitfalls of PCR-based rRNA analysis. FEMS Microbiology Reviews 21: 213-229.

Witt DJ and Kemper M. 1999. Techniques for the evaluation of nucleic acid amplification technology performance with specimens containing interfering substances: Efficacy of boom methodology for extraction of HIV-1 RNA. Journal of Virological Methods 79: 97-111.

Woese C. 1987. Bacterial evolution, Microbiological Reviews, 6: 221-227. 
Woese CR and Fox GE. 1977. Phylogenetic structure of the prokaryotic domain: the primary kingdoms. Proceedings of the National Academy of Sciences of the United States of America 74: 5088-5090.

Woese CR, Fox GE, Zablen L, Urchida T, Bonen L, Pechman K, Lewis BJ, and Stahl D. 1975. Conservation of primary structure in 16S ribosomal RNA. Nature 254: 83-86.

Yeager PE and Sinsbaugh RL. 1998. Microbial diversity along a sediment detrital particle size gradient, Aquatic Ecology 32(4): 282-289.

Yeates C and Gillings MR. 1998. Rapid purification of DNA from soil for molecular biodiversity analysis. Letters in Applied Microbiology 27: 49-53.

Yu W, Dodds WK, Banks MK, Skalsky J, and Strauss E. 1995. Optimal Staining and Sample Storage Time for Direct Microscopic Enumeration of Total and Active Bacteria in Soil with Two Fluorescent Dyes. Applied and Environmental Microbiology 61: 3367-3372.

Zhou J, Bruns MA, and Tiedje JM. 1996. DNA recovery from soils of diverse composition. Applied and Environmental Microbiology 62: 316-322.

Zhou J, Xia B, Treves DS, Wu LY, Marsh TL, O’Neill RV, Palumbo AV, and Tiedje JM. 2002. Spatial and resource factors influencing high microbial diversity in soil. Applied and Environmental Microbiology 68: 326-334.

Ziemer CJ, Cotta MA, and Whitehead TR. 2001. Application of group specific amplified rDNA restriction analysis to differentiate among swine fecal and manure storage pit samples. United States Department of Agriculture, Agricultural Research Service Tektran Report Approved 2001-12-19.

Zlatkin IV, Schneider M, deBruijn FJ, and Forney LJ. 1996. Diversity among bacteria isolated from the deep subsurface. Journal of Industrial Microbiology 17: 219-227.

www.caves.org/grotto/louisvillegrotto/cavefaqs/cavefaqs.htm www.nrri.umn.edu "Understanding Dissolved Oxygen" www.alkami.com/methods/reftrbl.htm\#multiple 
APPENDIX A

\section{LIST OF ABBREVIATIONS}

A - absorbance

AFLP - Amplified Fragment Length Polymorphism

ARDRA - Amplified Ribosomal DNA Restriction Analysis

$\mathrm{bp}$ - basepairs

BSA - Bovine Serum Albumin

${ }^{\circ} \mathrm{C}$ - degrees Celsius

cfu - colony forming unit

$\mathrm{cm}$ - centimeter

$\mathrm{Co}-$ molar concentration of nucleotides in single-stranded DNA at $\mathrm{t}=0$

Cot - molar concentration of ssDNA at the time $t$

$\mathrm{Cot}_{1 / 2}$ - time in seconds for $50 \%$ reassociation of ss DNA

$\mathrm{CO}_{2}-$ Carbon dioxide

CTAB - Hexadecylmethylammonium bromide

DGGE - Denaturing Gradient Gel Electrophoresis

DNA - deoxyribonucleic acid

dNTPs - deoxynucleoside triphosphate mixture

ds - double stranded

EGTA - Ethyleneglycol-bis-(beta-Aminoethyl Ether) N,N,N',N'-Tetraacetic Acid 
EPA - Environmental Protection Agency

EtOH - Ethanol

gm - gram

GPS - Global Positioning Satellite

$\mathrm{Kb}$ - Kilobase pairs (1,000 basepairs)

L - liter

NASA - National Air and Space Administration

NCO - Nominal Cut-off

$\mu 1$ - microliter

$\mu \mathrm{m}-$ micrometer or micron

$\mu \mathrm{M}$ - micromolar

$\mathrm{ml}$ - milliliter

mg - milligram

$\mathrm{mM}$ - millimolar

ng - nanogram

$\mathrm{nm}$ - nanometer

PCR - Polymerase Chain Reaction

pg - picogram

PVPP - polyvinylpolypyrolidone

rDNA - ribosomal DNA (gene coding for the ribosomal RNA)

rRNA - ribosomal ribonucleic acid

RFLP - Restriction Fragment Length Polymorphism

RH - Relative humidity

RT-PCR - Reverse Transcriptase Polymerase Chain Reaction 
SDS - sodium dodecyl sulfate

SEWS - Salt Ethanol Wash Solution

sp. - an unidentified species of a particular genus

spp. - multiple species of a particular genus

ss - single stranded

SSC - Standard Saline Citrate Buffer

TAE - tris-acetic acid-sodium EDTA Buffer

TE - tris-EDTA Buffer

TGGE - Temperatrure Gradient Gel Electrophoresis

TNE - tris-EDTA-NaCl Buffer

T-RFLP - Terminal Restriction Fragment Length Polymorphism

$\mathrm{U}$ - units

$\mathrm{UV}$ - ultraviolet

ww - wet weight

$16 \mathrm{~S}$ - small subunit of the ribosome 


\section{CURRICULUM VITAE}

\section{Justine Kay Roback}

Born: February 10, 1964 in Lenawee County, Michigan

$\underline{\text { Education }}$

May 2005

University of Louisville, Louisville, KY

Doctor of Philosophy in Environmental Biology

May 2001

University of Louisville, Louisville, KY

Masters of Science in Biology

May 1987

University of Kentucky, Lexington, KY

Bachelor of Science in Biology

May 1982

Somerset High School, Somerset, KY

Diploma

Professional Experience

$2002-2003$

Motlow State College, Lynchburg, TN

Division of Science and Mathematics

Adjunct Professor

$1997-2001$

University of Louisville, Louisville, KY

Department of Biology

Teaching Assistant

1995-1998

Brown-Forman Corporation, Louisville, KY

Division of Microbiology Research \& Development

$\underline{\text { Lab Technician }}$

1995-1996

University of Louisville, School of Medicine, Louisville, KY

Department of Occupational Toxicology

Clinical Research Assistant

1991-1994

Georgetown University, Washington, DC

Division of GI/Hepatology

$\underline{\text { Research Biologist }}$ 
1991-1994

Department of Veterans Affairs, Washington, DC

Division of GI/Hepatology

Biologist/Lab Technician

1989-1990

Commonwealth of Kentucky, Frankfort, KY

Department of Health Services

Biologist/Lab Technician

1987-1989

Whip-Mix Corporation, Louisville, KY

Research \& Development

$\underline{\text { Research Assistant/Lab Technician }}$

$\underline{\text { Awards }}$

Department of Veterans Affairs Performance Award - 1992, 1993, 1994

Brown-Forman SPOT Award for Performance-1996, 1997

University of Louisville Department of Biology and Biology Graduate Student

Association Outstanding Service Award - 1999, 2000

Kentucky Waterways Alliance Outreach and Education Award - 1999

University of Louisville Graduate School Graduate Incentive Award - 1999

Leadership

Kentucky Waterways Alliance, Advisory Council - 1998, 1999

Biology Graduate Student Association, Secretary - 1997-1998

Biology Graduate Student Association, President - 1998-1999

Salt River Watershed Watch-Steering Committee, Scientific Advisory Panel - 1997-2000

\section{$\underline{\text { Publications }}$}

1. Gibert CL, Walshe DK, Montgomery JR, Pham DQ, Hill JH, Lokken G, Buskell-Bales Z, Collier K, and Seeff LB. The Prevalence of Syphilis Seroreactivity In Unselected Admissions to an Inner City Hospital. 34th ICAAC. Orlando, Florida. October 1994.

2. Pham DQ, Montgomery J, Buskell-Bales Z, Claggett J, Wilson L, Biswas R, and Seeff LB. Specificity of Second-Generation Enzyme-Linked Immunoassay (EIA) in Diagnosis of Hepatitis C Virus (HCV) Infection. Hepatology 1994;20:327A.

3. Pham D, Walshe DK, Montgomery J, Buskell-Bales Z, Collier K, Lokken G, Claggett J, Wilson L, Biswas R, Gibert C, and Seeff LB. Seroepidemiology of Hepatitis C and B in an Urban VA Medical Center. Hepatology 1994;20:326A. 


\section{EPILOGUE}

I have come a long way from the beginning of graduate school. I remember the first time I met with Dr. Atlas before even being admitted to the program at the University of Louisville. I was still living in Washington, DC working in a hepatitis research labotatory with Dr. Leonard Seeff and I had come from a series of clinically oriented microbiology jobs after graduating from the University of Kentucky with a B.S. in Biology. However, several months spent touring the western part of the U.S., living mostly in a tent, and the presence of microbial communities in environments as seemingly intolerant as the salt marshes in Death Valley and the thermal pools of Yellowstone (discovered by Dr. Norman Pace and Dr. Thomas Brock I would later learn) had convinced me that I wasn't to be a clinician. I wanted to study microbial diversity in the environment.

It was, however, with the mindset of a clinical microbiologist that I approached the question when asked by Dr. Atlas how I hoped to evaluate microbial diversity in any environmental sample. My idea was to simply inoculate a variety of agar plates, and then use traditional Bergey's Manual methods to identify the colonies. Dr. Atlas simply handed over several articles with references to others and said, "You might want to read some of these papers."

In the considerable amount of time I have spent in graduate school, much has changed in my personal life. I have experienced divorce, remarriage to a wonderful 
friend and labmate, the birth of two children, and a series of location transfers. This is nothing compared to the advances in studying microbial diversity in natural environments. The methods by which microbial diversity is examined have progressed rapidly, and knowledge regarding the role of microbes in our environment has increased accordingly. Some things, however, have remained the same: my interest in aquatic microbial ecology.

From the beginning of graduate school I knew I was interested in those microbes living in the aquatic environment. I had the pleasure to accompany Dr. Charlie Covell and others from the University of Louisville on a field course in Costa Rica, C.A. While visiting Costa Rica I became interested in the water chemistries of epiphytic bromeliads as habitats for microorganisms, and the effects of water quality on amphibian populations. I returned the following summer enrolled in a summer course Tropical Ecology, offered through the Organization for Tropical Studies (OTS) and the University of San Jose to begin sampling. Initial studies were abandoned when the University of Louisville terminated their relationship with OTS several years later. Although the research was never completed, the experience of visiting the rainforest and other tropical environments contributed vastly to my knowledge of diversity. I hope one day my children will have the opportunity to see such an ecological treasure.

I would continue to work on water quality issues only closer to home as I helped develop the Salt River Watershed Watch, a citizen based water monitoring group. I was fortunate to work with both Dr. Jan Stevenson and Dr. Jeff Jack on this project. During this time I was also heavily involved in student government serving as the president of the Biology Graduate Student Association. At least by then, I had quit both of my outside microbiology jobs. I was gaining experience teaching students in 
introductory microbiology lab, and giving presentations to the public regarding water quality monitoring by citizens. In addition, I was attending departmental seminars, workshops, and meetings. Coursework, comprehensives, and progress report forms were of course part of the formal education process. My calendar was full. Dr. Atlas gently reminded me that I should focus on some sort of research project.

It was in 1998 when I took Dr. Pearson's cave biology course and was fascinated to learn that microbiologists were just beginning to scratch the surface so to speak in their exploration of the depths of caves. I immediately began collecting samples and addressing questions in an environment totally removed from traditional constraints of diversity.

In 2000, I married Kevin Smith: my labmate, soulmate, and friend who had completed his Masters degree in our laboratory and taken a job as a QC Specialist at the Jack Daniels Distillery in Lynchburg, TN. I spent the next several years having children, enjoying the country life, and determining the quality of cave waters used in the process of creating the famous Tennessee Whiskey (unpublished sensory methods). In addition to life changes, the events of September 11, 2001, and the death of my friend and close colleague David Smith during my time at the University of Louisville were unexpected and have changed the way I look at life and education.

In the end, my study has taken me back to water, as I believe the microbial diversity in caves is dependent upon nutrient input and that this occurs through the stable input of surface waters. I look at it as a sort of microbial hydroponics. If we change the properties of the water entering the cave system or we divert water for other uses, I believe we will have a negative impact on microbial cave communities. Since we know that bacterial communities are participating in nutrient cycling and bioremediation of 
groundwaters, I take this seriously. I think about possibly the most important $\mathrm{r}$ important tenet from Dr. Atlas, "with knowledge comes responsibility."

Thanks to many mentors, I have learned much about a vast array of microorganisms, the environments in which they exist, and the metabolisms by which they affect our world, mostly making it a better place. So it is with the mindset of a microbial ecologist and a cave conservationist that I leave the University of Louisville bound for whatever opportunities life has in store. 
